
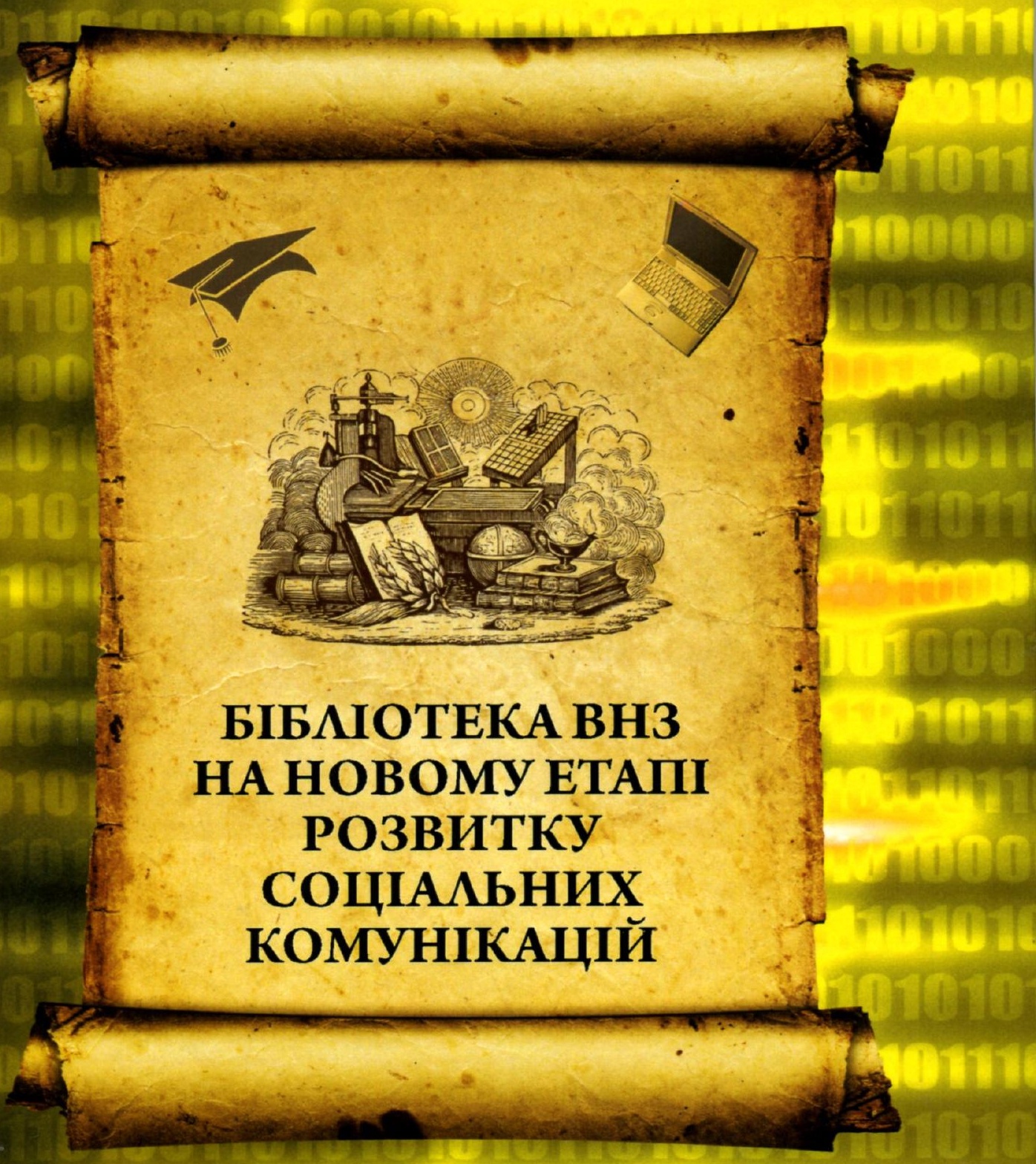
МIНICТЕРСТВО ТРАНСПОРТУ ТА ЗВ'ЯЗКУ УКРАЇНИ ДНІПРОПЕТРОВСЬКИЙ НАЦІОНАЛЬНИЙ УНІВЕРСИТЕТ

ЗАЛІЗНИЧНОГО ТРАНСПОРТУ ІМЕНІ АКАДЕМІКА В. ЛАЗАРЯНА

\section{БІБЛІОТЕКА ВНЗ НА НОВОМУ ЕТАПІ РОЗВИТКУ СОЦІАЛЬНИХ КОМУНІКАЦІЙ}

За загальною редакцією д-ра історичних наук

В. О. Ільганаєвої та Т. О. Колесникової 


\title{
Рецензенти:
}

Д-р наук із соиіальних комунікаиій, дочент ХДАК Г. В. Шемаєва Д-р філософських наук, проф. ДГУ Ю. О. Шабанова.

\begin{abstract}
Авторський колектив: Бебик В. М. - розділ I, п. 1; Бояріна Л. О. - розділ V, п. 2; Власова Т. І. - розділ I, п. 3; Влащенко Л. Г. - розділ V, п. 2; Волинець В. М. . - розділ IV, п. 1; Грищенко Т. Б. - розділ V, п. 2; Демченко В. Д. - розділ I, п. 2; Дубчак Л. В. - розділ III, п. 4; Кирко С. Ю. - розділ VI, п. 1; Колесникова Т. О. - розділ I, п. 4, розділ II, п. 1, розділ III, п. 1; Кондратюк I. Б. - розділ I, п. 5; Мямліна А. В. - розділ II, п. 3; Назаровець С. А. - розділ IV, п. 2; Непран Н. В - розділ VI, п. 1; Нікітенко О. М. - розділ V, п. 2; Пекур О. В. - розділ II, п. 2; Перепелица I. Г. - розділ III, п. 2; Романова В. М. - розділ III, п. 3; Савенкова Л. В. - розділ IV, п. 1; Семененко Л. П. - розділ VI, п. 1; Ткаченко Т. П. . - розділ V, п. 1; Цимбалюк С. Я. - розділ III, п. 4; Яшанов С. М. - розділ VI, п. 2.
\end{abstract}

\section{БІБЛІОТЕКА ВНЗ НА НОВОМУ ЕТАПІ РОЗВИТКУ СОЦІАЛЬНИХ КОМУНІКАЦІЙ}

Б 59 БІБЛІОТЕКА ВНЗ НА НОВОМУ ЕТАПІ РОЗВИТКУ СОЦІАЛЬНИХ КОМУНІКАЦІЙ: Монографія [Текст]/ За ред. В. О. Ільганаєвої, Т. О. Колесникової - Дн-вськ: Вид-во Маковецький, 2010. - 200с. - ISBN 978-966-1507-50-9

В монографії представлений аналіз теоретичних та прикладних проблем трансформаційних процесів як в галузі соціальних комунікацій взагалі, так і бібліотечно-інформаційній справі зокрема. Відображені загальносистемні аспекти бібліотечної діяльності в умовах становлення системи соціальних комунікацій та галузеві умови діяльності бібліотек ВНЗ, організаційнофункціональні, технологічні і управлінські аспекти, а також підходи, методи та досвід вирішення різноманітних задач, які виникають в процесі наближення бібліотек до вимог сучасного освітнього простору інформаційного суспільства.

Монографія розрахована на наукових співробітників, працівників бібліотек, студентів і аспірантів фахових спеціальностей.

(с) Видавництво Маковецький Ю.В. Дніпропетровськ, 2010 


\section{ПЕРЕДМОВА}

Пропонована читачам книга представляє собою рідкісне для української професійної спільноти явище, практично унікальне. Мається на увазі те, що працівники бібліотечно-інформаційної сфери рідко об'єднуються для висвітлення результатів своєї науково-дослідницької або практичної діяльності, демонструючи певну єдність в підходах, дослідницькому або управлінському інструментарії, баченні структури актуальної проблематики, оцінок, об'єктивної критики або аналізу діючої практики діяльності бібліотек, в тому числі, міжнародної. Важливість цього видання в тому, щоб подібні видання одержали поширення в нашому професійному середовищі.

Примітно, що авторами цієї колективної монографії являються переважно працівники вищих навчальних закладів (ВН3) України та Росії, тобто безпосередні наглядачі та учасники процесів, що відбуваються в бібліотечній сфері в сучасних умовах. Цікавим і пізнавальним, однак, $\epsilon$ не тільки той факт, що практики активно включені в науково-теоретичний аналіз змін, що виникають в бібліотеках та пошук шляхів вирішення виникаючих проблем, а, насамперед, в тому, що відібрані матеріали фактично відображають процес переформатування професійної свідомості бібліотекарів, засвоєння нових когнітивних конструктів. Останнє є результатом усвідомлення сутності механізмів розвитку бібліотек як соціально-комунікативних організацій. Автори демонструють використання відповідного понятійного апарату, розширення аспектів міждисциплінарної та міжнаукової взаємодії бібліотекознавства, а також основних напрямів інтеграції бібліотек в інформаційно-комунікативну підсистему суспільства.

Матеріали для монографії були відібрані під час проведення Міжнародної науково-практичної конференції «Бібліотека ВНЗ на новому етапі розвитку соціальних комунікацій», яка відбулась 22-23 квітня 2010 року у Дніпропетровському національному університеті залізничного транспорту імені академіка В. Лазаряна. Можливо, книга не без недоліків, проте, вона, як у мініатюрі, відображає головні тематичні напрями і підходи розглядання і вирішення практичних задач в умовах масштабних трансформаційних змін в бібліотеках.

Книга наглядно демонструє, що бібліотекознавство вийшло за межі вузько відомчої проблематики, що конкурує за своєю значимістю, за впливом на суспільну свідомість 3 дисциплінами документально-комунікаційного циклу, інформатикою, теорією масових комунікацій, що було особливо помітно в період поч. XX ст-70-і pp. XX ст. Від часів глобальної інформатизації, яка охопила суспільство в останні роки XX ст., позначились основні точки дотику всіх соціально-комунікаційних структур, що забезпечують процеси збору, обробки, зберігання, передачі, представлення та розповсюдження соціально значимої інформації в будь-якому вигляді: звук, письмо, відображення, рух, колір і навіть запах. Інформаційно-технічні інновації стали фактором реструктуризації в комунікаційній підсистемі суспільства в цілому і в окремих ії підсистемах. Питання комп'ютеризації, автоматизації, інформатизації бібліотек, фактично, стали ключовими на багаті десятиліття і залишаються такими і по цей день. Однак 
кількісні і якісні відмінності, ступінь глибини розкриття відповідної тематики являються відображенням нерівноваги освоєння соціально-інформаційного простору в різних країнах і регіонах сучасного глобалізованого суспільства, відображає тим самим ступінь співвідношення бібліотечних організацій змінам комунікаційної культури суспільства.

Основною характеристикою інформаційного простору сучасної цивілізації в XXI ст. стала медіальність. Нові можливості дозволили критично переглянути роль і значення традиційних, окремо еволюційних комунікативних структур $\mathrm{i}$ визначити сутнісні основи їх функціонування та єдине соціальне призначення забезпечення соціальної взаємодії, результатом якої є соціокультурне наслідування, формування соціальної пам'яті і соціальної свідомості.

Сучасна соціокультурна ситуація висунула науку і освіту на лідируючі позиції в процесах забезпечення соціальної безпеки і прогресу. Цим пояснюється інтерес до питань інформаційного сервісу, технологіям, методам електронної освіти, задачам і управлінню бібліотечно-інформаційною діяльністю і розвитку когнітивних процесів, технологій, а також удосконалення заходів і методів роботи 3 користувачами в умовах нового соціокультурного середовища. Підтвердженням цього $є$ матеріали пропонованої монографії. В ній відображені як загальносистемні аспекти бібліотечної діяльності в умовах становлення системи соціальних комунікацій, так і галузеві умови діяльності бібліотек ВН3, організаційно-функціональні, технологічні і управлінські аспекти, а також підходи, методи та досвід вирішення різноманітних задач, які виникають по мірі наближення бібліотек до вимог сучасного освітнього простору інформаційного суспільства.

Монографія складається з окремих робіт, що представляють єдину структуру і певну послідовність розкриття актуальної проблематики соціальних комунікацій: аспекти загальносистемного бібліотекознавчого значення (В. М. Бебик, В. Д. Демченко, Т. І. Власова, Т. О. Колесникова, І. Б. Кондратюк); педагогічні аспекти діяльності бібліотек ВНЗ (Т. О. Колесникова, О. В. Пекур, А. В. Мямліна); інформаційні ресурси і корпоратизація їх формування і використання (Т. О. Колесникова, І. Г. Перепелиця, В. М. Романова, С. Я. Цимбалюк, Л. В. Дубчак); проблеми і задачі інтелектуалізації бібліотек ВНЗ (Л. В. Савенкова, С. А. Назаровець); управлінські питання і менеджмент (Т. П. Ткаченко, Л. О. Бояріна, Л. Г. Влащенко, Т. Б. Грищенко, О.М.Никитенко); конкретноприкладні аспекти роботи в умовах електронного бібліотечного середовища (Л. П. Семененко, Н. В. Непран, С. Ю. Кирко, С. М. Яшанов).

Книга призначається науковим співробітникам, працівникам бібліотек, студентам і аспірантам фахових спеціальностей.

В. О. Ільганаєва, доктор історичних наук, професор Харківської державної академії культури. 


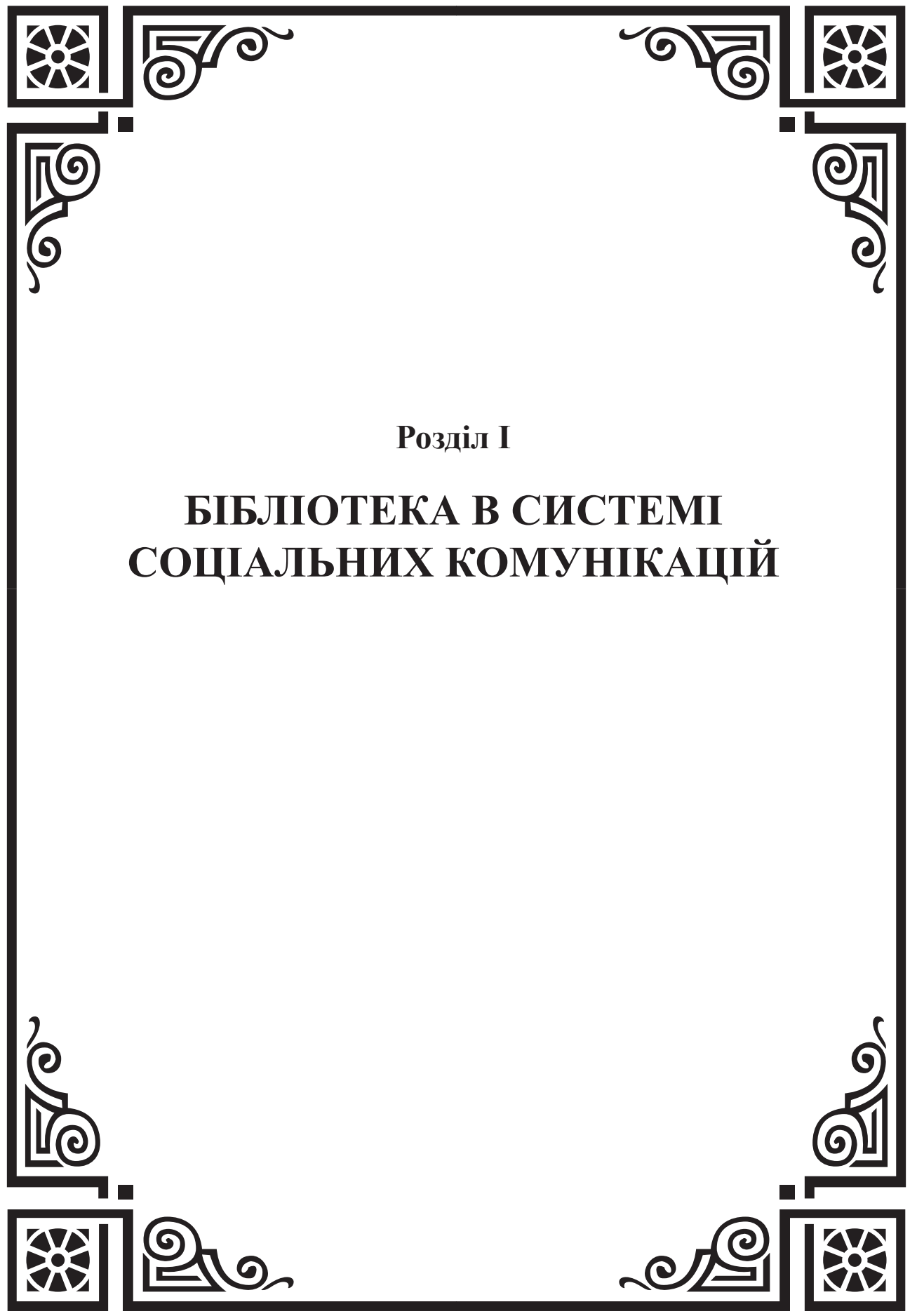




\section{1. СОЦАЛЬНІ КОМУНІКАЦЇ̈ ТА ЇХ РОЛЬ У ФУНКЦІОНУВАННІ СУСПІЛЬНОЇ СФЕРИ}

\section{Соціальні й політичні комунікації: зміст і поняття}

Суспільна сфера, що загалом складається із суспільно-політичної, соціально-економічної та духовно-інтелектуальної сфер суспільства, з метою збереження своєї цілісності і керованості потребує здійснення відповідних заходів із самоорганізації та самоуправління суспільного життя.

В цьому зв'язку й політична, економічна, та духовна системи суспільства (якщо вони є життєздатними) мають постійно враховувати зміну внутрішньої й зовнішньої ситуації. Відтак, у своєму функціонуванні вони постійно залежать від інформації про розвиток відповідної системи, що надходить іззовні, а також від власних структур.

Зрозуміло, що поділ на політичну, економічну та духовну системи є доволі штучним і носить методологічний характер (так простіше їх досліджувати), оскільки всі вказані види суспільної системи взаємно пов'язані і не можуть існувати одна без одної.

В даному контексті ми й повинні розуміти, що соціальні комунікації є своєрідним інформаційно-комунікаційним полем суспільного життя, що має соціальний характер, з'єднує всі компоненти суспільної сфери (політичні, економічні, духовні) та структурує відповідну суспільну (політичну, економічну, духовну) діяльність.

Наприклад, з погляду К. Дойча (Гарвардський університет, США), який використав під час аналізу політичної системи загальнокібернетичні ідеї Н. Вінера, політична система ніколи не перебуває у стані рівноваги, оскільки постійно бере участь у динамічних процесах. Політика та врядування досліджуються в цьому разі як процес управління та координації зусиль щодо досягнення певних цілей [2].

Наскільки повним є інформаційно-комунікаційне забезпечення діяльності політичної системи? Як вона реагує на зміну ситуації, чи не запізнюється? Які можливості вона має щодо прогнозування, передбачення розвитку подій? Чи може вона адекватно впливати на небажані зміни? Усе це - життєво важливі проблеми.

Відтак, для забезпечення ефективного функціонування політичної системи необхідними та першочерговими атрибутами має бути обов"язкова наявність відповідних систем інформування та соціальної комунікації (в цьому випадку політичної комунікації).

Початок вивчення проблем політичної комунікації пов'язують 3 дослідженням пропаганди в період Першої світової війни (1914-1918). Але фундаментальні праці 3 цієї проблематики та, власне, термін політична комунікація з'явилися наприкінці 40-х років XX ст.

Виокремлення цього напряму на межі соціальних і політичних наук було зумовлене розвитком кібернетичної теорії та запровадженням нових інформаційно-комунікаційних технологій і систем. 
Нині дослідники політичної сфери суспільства особливу увагу приділяють його інформаційно-комунікаційним аспектам, проблемам функціонування масмедіа та суспільних комунікацій.

Серед цілого шерегу дослідників вказаних аспектів суспільного життя можемо назвати таких авторів, як Дж. Бенігер [35], Д. Бродер [36], М. Власенко, С. Зорькта, М. Сиротич [6], З. Вурмен [50], Ю. Габермас [39], Дж. Гол [7], Р. Ентман [38], І. Жиляєв [10], Дж. Кері [37], Дж. Лал [14], М. Мак-Люхан [41], Д. Мак-Квайл [42], В. Остроухов та В. Петрик [18], В. Паттерсон [43], Дж. Пауелл [44], Г. Почепцов [21-23], Г. Ріді [45],В. Різун [26], Л. Сабато [46], Дж. Спір [49], А. Улєдов [29], М. Харгрівз [40], Р.-Ж. Шварценберг[48], М. Шрам [47],В. Щербина [32] та ін.

Якість урядових рішень, передбачення та випередження залежать від інформації, якою володіє суспільна система в цілому і політична система зокрема. Остання може мати серйозні проблеми через недостовірність або недостатність інформаційних даних.

Нову інформацію вона мусить порівнювати з раніше отриманою (що відбиває iї політичний досвід) для того, щоб в подальшому можна було ухвалювати більш оптимальні управлінські рішення.

Існує чимало визначень терміну політичної комунікації. Скажімо, Р. Шварценберг вважає, що політична комунікація є процесом передавання політичної інформації, що циркулює від однієї частини політичної системи до іншої, між політичною та суспільною системами, а також між політичними структурами, суспільними групами та індивідами [48].

Все це, безумовно, правильно. Але дане визначення терміну політичної комунікації уособлює в собі, так би мовити, інституціональний підхід, котрий не враховує власне політико-процесуальні, політико-культурні та соціальнопсихологічні аспекти суспільного життя.

На нашу думку, політична комунікація - це проиес передавання, переробки та прийняття політичної інформаиї суб'єктами та об'єктами політики, здійснюваний під час функціонування політичної сфери суспільства.

І цей процес, дійсно, відбувається в контексті багатостороннього обміну політичною інформацією за наступними рівнями політико-владної ієрархії:

- по вертикалі (індивід-група-суспільство чи національна влада-регіональна влада-локальна влада);

- по горизонталі (президент-парламент-уряд чи обласна адміністрація - обласна рада) тощо.

Відповідно до такого методологічного підходу ми пропонуємо й визначення терміну соціальна комунікація - процес передавання, переробки та прийняття соиіальної інформації, здійснюваний суб'єктами та об'єктами суспільної сфери.

Зрозуміло, що даний процес соціальної комунікації відбувається під час багатостороннього та різнорівневого обміну соціальною інформацією (якщо там $€$ людина - процес набуває соціальності) між політичною, економічною та духовною сферами суспільства та їхніми окремими структурами. 
Повертаючись до політичної комунікації (як різновиду комунікації соціальної), слід зазначити, що кожна політична система розгортає власну мережу політичної комунікації відповідно до своїх можливостей. I ця мережа розвивається одночасно із становленням та розвитком політичних структур суспільства.

Однак існує й безпосередній зв'язок між рівнем соціально-економічного розвитку суспільства та рівнем розвитку відповідних структур політичної комунікації. Останній визначається як інформаційно-технологічним та інженернотехнічним рівнем і способами передавання інформації, так і базовою ідеологією політичної системи.

Як і суспільства, політичні системи можуть бути ліберальними або авторитарними чи тоталітарними. Відповідну типологію мають і системи політичної комунікації.

Зокрема, ліберальні структури політичної комунікації грунтуються на демократичних підходах, коли існує постійний діалог між владою та суспільством. 3 погляду цієї концепції можна говорити про “уряд громадської думки”, який $є$ виявом демократії крізь призму взаємообміну інформацією між правителями та підлеглими.

Соціальна та політична комунікації життєво необхідні суспільній та політичній системам. А політичний аналіз (і подальший політичний прогноз) має враховувати проблеми інформації та соціальної й політичної комунікації в поєднанні з іншими проблемами, як це робиться в межах функціональної концепції дослідження політичної сфери суспільства.

В рамках цієї концепції, наприклад, Г. Алмонд і Дж. Коулмен розглядали комунікацію з погляду іiі гомогенності, мобільності, обсягів і спрямованості $[1 ; 34]$.

Ефективне суспільне й політичне управління (незалежно від рівня розвитку суспільства) потребує, щоб політичні “послання” (гасла, тексти, повідомлення) могли розуміти усі пересічні громадяни. Якщо пересічний „громадянський загал” знає й дотримується певних загальноприйнятих “правил гри”, процес суспільного управління відбувається належним чином [17].

Окрім того, слід зазначити, що політична інформація має бути диференційовано „упакованою”- залежно від адресата (жителі міста чи села, робітники чи підприємці, безробітні чи науковці).

Хоча, звичайно, абсолютно гомогенних систем політичної комунікації не існує. Може йтися лише про середній загальний рівень культурного та політичного розвитку країни. В країнах з достатньо високим рівнем загальної та політичної культури в процесі політичної діяльності (наприклад, під час виборчої кампанії) теж потрібно вибудовувати політичну комунікацію в залежності від особливостей певних цільових груп громадян.

Аналогічно можна класифікувати системи політичної комунікації з погляду мобільності, оперативності інформації, що циркулює ії каналами. Якщо, скажімо, газети й журнали доходять до читачів лише через тиждень після виходу, це, безперечно, не $є$ ознакою високого рівня розвитку політичної системи взагалі та 
системи політичної комунікації зокрема. Те саме можна сказати і про обсяги інформації та іiї спрямованість. У розвинених у цьому сенсі політичних системах інформація надходить не тільки згори вниз директивним шляхом, а й навпаки: від пересічних громадян до урядових структур найвищого рівня.

Політична комунікація є специфічним видом політичних відносин і розглядається як невід'ємний елемент політичної сфери суспільства, частина його політичної свідомості.

Масова комунікація (або інформаційно-комунікаційна діяльність) є діяльністю соиіального суб'єкта з виробництва й розповсюдження соиіальної інформації, націленої на формування суспільної свідомості суб'єктів та об'єктів суспільної сфери та відповідного спрямування їхньої (політичної, економічної, духовноі) діяльності.

Ця діяльність здійснюється з допомогою специфічних суспільних інститутів - засобів масової комунікації.

Узагалі суспільна (політична, економічна, духовна) та інша інформація може передаватися трьома основними способами комунікації:

- засобами масової комунікації;

- суспільними організаціями;

- неформальними контактами.

У першому випадку йдеться про друковані (газети, журнали, книжки, плакати, листівки), аудіовізуальні (телебачення, радіо, мобільний зв'язок) або електронні (інтернет) засоби масової комунікації.

Останнім часом ми дедалі більше спостерігаємо поєднання переваг згаданих вище „чистих” видів ЗМК у так званих мульти-медіа ЗМК, котрі дозволяють комплексно продукувати, передавати і приймати інформацію за допомогою поліграфічних (друкованих), аудіовізуальних та Інтернет-технологій.

У другому випадку мають на увазі комунікативні можливості урядових організацій, політичних партій, суспільних організацій, рухів, груп тиску і т. ін. Останні використовуються як двосторонні ланцюги обміну політичною інформацією між правителями та підлеглими громадянами.

Процес комунікації через неформальні контакти характеризується двома ступенями передавання інформації. Аудиторія сприймає інформацію не безпосередньо від джерела інформації, а від лідерів громадської думки. Отже, перша хвиля переважно впливає на лідерів громадської думки, а друга вже поширюється від них. Отже, останні є по суті ретрансляторами. (Їм, до речі, довіряють більше, ніж мас-медіа, оскільки знають безпосередньо).

I хоча спосіб неформальних контактів політичної комунікації був найефективнішим у примітивних суспільствах, людський чинник завжди буде одним із найважливіших, оскільки безпосереднє спілкування між людьми важко замінити чимось іншим.

Невід'ємною складовою формування, фіксації та самовідтворення ідентичності будь-якої нації та держави як соціокультурної й політичної спільноти $\epsilon$ національно-державні символи та ідеали. Зрозуміло, що вони не можуть самовідтворюватися без безпосередньої реалізації комунікативним шляхом. 
Символ є ідейною або ідейно-образною структурою. У широкому розумінні символ - це образ, у структурі якого предметний образ і зміст постають як нерозривні частини одного цілого.

Символи можна відображати графічно - у вигляді доісторичного хреста (запозиченого у IV ст. н.е. християнською церквою у язичників), герба, прапора, серпа й молота або таких людських постатей, як дядько Сем (США), Джон Булл (Великобританія), Маріанна (Франція).

У якості символів держави можуть використовуватися меч, військо, поліція, або, скажімо, урядові будинки: Білий дім (США), Кремль (Росія), Єлисейський палац (Франція), президентський палац на Банковій (Україна) тощо.

Різноманітні символи мають велике значення в житті людей. 3 допомогою символів вони взаємодіють одне з одним, і в цьому плані символи є певними засобами регулювання соціальної поведінки. Це визначається, насамперед тим, що будь-яка інформація, що сприймається суб'єктом, $є$ певною сукупністю візуальних і звукових символів. I кожен суб'єкт розшифровує іiі зміст у формулах, що мають для нього певний сенс [22; 27].

Кожен народ пошановує власні національно-державні та етнічно-релігійні символи, які створюються упродовж тривалого часу та базуються на давніх традиціях. Частина їх формується спонтанно, частина - запроваджується політичною елітою. I дуже часто, запроваджуючи нові символи, політична еліта використовує старі й популярні в народі символи, змінюючи їх зміст $[15 ; 20 ; 31 ; 35]$.

Центральне місце в системі політичної символіки, яка $\epsilon$, по суті, субсистемою політичної системи взагалі, посідають прапори, конституції, гімни, свята, грошові знаки, політичні ритуали (наприклад, процес інавгурації новообраного президента в США чи Україні) тощо. Останні $є$ важливим компонентом “громадянської релігії, характерної для певного суспільства.

Завершеним і сконцентрованим втіленням ідеалів свободи і прав людини стала для американців (до речі, подарована їм французами) статуя Свободи, яка $\epsilon$ символом “американської мрії”, успіхів країни необмежених можливостей.

Виразником національного духу, чинником, що сприяє формуванню національної самосвідомості, та водночас символом країни можуть бути міста. Скажімо, Київ для більшості українців - це насамперед Президент, Верховна Рада, Кабінет міністрів, Києво-Печерська лавра та Софійський собор.

Символічним $є$ також вибір назви національної грошової одиниці України - гривні. У контексті того, що в той час як Україна не мала власної державності, (Московське царство перебрало на себе, власне кажучи, українську назву держави - Русь), введення назви української грошової одиниці, тотожної назві грошової одиниці Київської Русі, було глибоко символічним актом. Він немов би перекинув місток психологічного зв'язку громадян українського суспільства 3 пращурами, чия держава була однією 3 наймогутніших у тодішній Європі.

Громадська думка формується насамперед під впливом мас-медіа. Зрозуміло, що політична, й особливо правляча, еліта намагається переконати 
більшість населення у правильності своїх дій і доцільності свого подальшого перебування при владі.

У цьому контексті виокремлюють констатуючу (нейтральну) та спонукальну (яка закликає до певних дій) політичну інформацію. Спонукальна інформація, у свою чергу, може бути спрямована на активізацію (“підштовхування” до дій у певному напрямі) і дестабілізацію (руйнування політичних структур, норм i форм поведінки або діяльності).

Якщо подивитися на політичну інформацію 3 погляду використовуваних при трансляції останньої засобів аргументації, то можна виокремити логічне та емоційне переконання.

Логічне переконання орієнтується на раціональну, доказову, наукову аргументацію (не всім, до речі, доступну в наслідок різного рівня свідомості, культури і т.ін.).

Емоційне переконання покликане впливати на емоційний елемент людської психіки (тут сфера формуючого впливу, безумовно, є значно ширшою внаслідок фрагментації і несистемності отримуваної інформації та відповідного рівня суспільної свідомості). Мета - змінюючи систему ціннісних орієнтацій особистості, примусити ії діяти в заданому пропагандистами напрямі.

Політична інформація, що надходить до ії споживача, може сприйматися повністю, частково (після внутрішньої ідейно-політичної, релігійної, етнічної чи індивідуально-психологічної “цензури”) або не сприйматися взагалі.

У цьому контексті велику роль відіграє соціокультурна (суспільнополітична, соціально-економічна, професійно-фахова чи етнічно-релігійна) група, до якої належить (якщо належить) споживач інформації.

Напевно, варто назвати особливості впливу соціокультурної групи на сприйняття політичної інформації індивідом:

- особистий погляд споживача інформації перебуває під сильним впливом групи, до якої він належить або прагне належати;

- людина заохочується (або карається) за дотримання (або невиконання) групових стандартів;

- якщо думка “озвучена” в аудиторії, іiі важче змінити, ніж особистий погляд;

- групові дискусії та рішення сприяють послабленню внутрішнього опору певній думці;

- підтримка навіть однієї людини ослаблює тиск “групового мислення”;

- найортодоксальніші прихильники групи найменш готові до сприйняття інформації, яка суперечить їі нормам;

- велике значення для успішного засвоєння інформації мають форма й особливості її подання (довіра до інформатора, враження від його об’єктивності та правдивості тощо).

Окрім того, варто звернути особливу увагу на адресність політичної інформації, іiі “упаковку” відповідно до споживацьких стандартів різних груп населення.

Якщо інформація подається “упакованою” в стандартні кліше (ідеологічнополітичні, мовно-культурні чи етно-релігійні) цієї групи, ви отримаєте значно 
більше шансів на успішне засвоєння цієї інформації вищезгаданою групою.

Ось тут ми вже наблизилися до формулювання певних узагальнень щодо визначення особливостей (принципів та функцій) культури політичної комунікації.

\section{Основні принципи політичної комунікації:}

- пріоритетність якостей і цінностей цієї культури (ієрархія);

- рівні права усіх громадян на отримання інформації (демократія);

- наближеність до культури нації, етносу, конфесії, класу тощо (ідентичність);

- урахування морально-етичних норм (мораль).

Характер політичної комунікації в суспільстві, рівень ії розвитку визначаються рівнем загальної та політичної культури суспільства, опосередковуються їх цінностями й нормами. Але політична комунікація як засіб існування й передавання політичної культури саме й визначає рівень політичної культури суспільства, особливості функціонування політичної сфери суспільства.

3 урахуванням особливостей функціонування політичної сфери суспільства варто назвати й основні функції політичної комунікації:

- поширення ідейно-політичних цінностей, знань, політичної інформації;

- формування політичної свідомості;

- поширення норм політичної культури, здійснення політико-культурного обміну, розвиток політичної культури суб'єктів політики (індивідів, груп, політичних структур);

- інтеграція та регулювання політичних відносин;

- підготовка та сприяння громадськості до участі в політичній діяльності.

Насамкінець зазначимо, що соціальна та політична комунікація мають бути засобами узгодження та координації суспільно-політичних інтересів на основі повного інформування громадян, поваги до прав і свобод особистості, демократичної політичної культури та свободи мас-медіа від владних та бізнесових структур (національних та зарубіжних). Це ідеал, якого треба прагнути шляхом постійної та копіткої роботи усім суб'єктам суспільного життя.

\section{Інформаційна влада та медіа-комунікації}

Політична сфера суспільства, без сумніву, потребує найбільшою мірою, ніж інші, спеціальних засобів соціального та політичного інформаційного обміну, встановлення та підтримки постійних зв'язків між суб'єктами політики та суб'єктами і об'єктами політики.

Звичайно, економічна сфера суспільства також потребує інтенсивних соціально-інформаційних обмінів щодо стану економіки, цін, технологій, патентів і т.ін., проте ці обміни не мають таких інформаційно-комунікаційних масштабів, оскільки основою функціонування економічної сфери суспільства $\epsilon$ все-таки ринкове саморегулювання.

Природа політики потребує опосередкованих форм спілкування та спеціальних засобів соціальної та політичної комунікації між різними носіями влади, державою та громадянами тощо. 
Сучасні політичні стандарти (втілені у більшість конституцій планети) передбачають, що в демократичному, правовому суспільстві влада поділяється на законодавчу, виконавчу й судову [2].

Це, безумовно, правильно. Однак глобальна інформатизація суспільства, широке впровадження нових інформаційно-комунікаційних технологій (супутникового та кабельного телебачення і радіо, мобільного зв'язку, мульти-медіа) зробили актуальними розмови про інформаційну владу.

На нашу думку, інформаційна влада $\epsilon$ здатністю власників інформаціі шляхом отримання, селекиіі, тлумачення, компонування, продукування та розповсюдження інформації впливати на формування суспільної свідомості та культури, спонукати суб'єктів суспільної сфери (політики, економі$\kappa и$, духовної сфери) до запрограмованих чи спонтанних дій у заданому напрямі.

Інформаційна влада може реалізовуватися через спеціалізовані засоби передавання інформації, які забезпечують єдність волі, цілісність і цілеспрямованість дій великої кількості людей, і називаються мас-медіа, або засобами масової комунікації (ЗМК).

ЗМК $є$ спеціалізованими установами для відкритого, публічного передавання будь-якої інформації будь-яким особам за допомогою спеціального технічного інструментарію.

До ЗМК належать друкована, аудіовізуальна, електронна преса, масові довідники, кіно-, відео-, аудіоносії інформації, супутникові, кабельні, комп'ютерні мережі - усе, що може нагромаджувати й передавати важливу для суспільного життя інформацію.

Оскільки йдеться про владний потенціал мас-медіа, неможливо обійтися без такого ключового поняття, як свобода преси.

3 появою перших газет виникла проблема свободи преси, яка стає предметом полеміки, а згодом і загострюється у XVIII ст. у роки Французької буржуазної революції.

У ці часи була сформульована демократична буржуазна концепція свободи преси, яка грунтувалася на трьох основних тезах:

- відокремлення новин від коментарів;

- відкритість урядової інформації;

- відсутність цензури [4].

Свободу преси в сучасних умовах, напевно, варто розглядати як свободу діяльності ЗМК, оскільки поняття преси у ХХ ст. радикально змінилося.

Отже, свобода ЗМК $є$ життєво необхідною умовою не лише для волевиявлення людьми своїх думок і прагнень. Без ії реалізації, як стверджує Дж. Кін, годі й говорити про побудову громадянського суспільства, гарантування конституційності демократичного ладу [11].

У світі існують дві основні доктрини свободи ЗМК: західноєвропейська (на базі французької Декларації прав людини і громадянина) і північноамериканська (на базі американського “Білля про права").

Звичайно, ці доктрини дуже осучаснилися, пройшовши, як свідчать такі до- 
слідники, як Е. Деніс, Дж. Мерил [9], В. Корнхаузер [13] шлях від ліберального максималізму до соціальної відповідальності.

Однак цей процес ще й досі не завершився. Свідченням цього є проблеми “папарацці” та “орал-гейт”, що активно дискутувалися громадськістю після загибелі уельської принцеси Діани та скандального процесу Б. Клінтон М. Левінські, або взаємні публічні звинувачення Ю. Тимошенко та В. Ющенка у злочинних діях.

Щоправда, існує ще доктрина “свободи преси” - авторитарна, коли масмедіа можуть говорити про те, що дозволяє влада (комунізм, націоналсоціалізм, радикал-конфесіоналізм). Проте це вже, на думку Ф. Хайєка, мало поєднується зі словом “свобода" взагалі [30].

Мас-медіа є невід’ємною складовою механізму функціонування демократії, ii ціннісних і нормативних засад. Саме ЗМК можуть допомогти індивіду вийти за межі його безпосереднього життєвого досвіду і включитися в політичну діяльність.

Для того щоб гарантувати можливість вільного отримання інформації, потрібно обмежити вплив влади та бізнесу на ЗМК, забезпечивши водночас контроль над їх діяльністю з боку суспільства $[9 ; 12 ; 14]$.

Це можна зробити лише на основі розуміння соціальних функцій ЗМК:

- інформування громадян про найважливіші для них і влади події;

- освіти (доповнює діяльність спеціальних навчальних закладів - шкіл, технікумів, університетів, академій);

- критики й контролю, реалізація яких спирається на громадську думку та закон;

- артикуляції та інтеграції, що сприяє об'єднанню та згуртуванню суспільних інтересів, є умовою для формування впливової опозиції;

- мобілізації, що спонукає людей до певних політичних дій (або свідомої бездіяльності);

- інновації, що виявляється в ініціюванні політичних змін шляхом постановки важливих проблем перед владою й громадськістю;

- формування громадської думки з ключових питань суспільного життя;

- оперативну, що полягає в обслуговуванні ЗМК політики певних партій, громадських рухів, соціальних групп [19].

Як зазначалося, основними етапами інформаційного процесу є отримання, добір, тлумачення, коментування і розповсюдження інформації.

Одним із найважливіших засобів політичного впливу ЗМК є продукування та добір інформації.

Звичайно, тут спрацьовують як політичні симпатії власників і керівників ЗМК, так і ринкові критерії інформаційної політики мас-медіа.

Теми, автори й учасники публікацій і передач добираються керівниками (власниками) мас-медіа за наступними принципами:

- важливість (справжня чи уявна) для громадян - загроза миру, тероризм, екологічна безпека, катастрофи;

- неординарність (екстремальні події - війна, голод, злочини - домінують над явищами буденного життя, що спонукає і провокує ЗМК на негативізм та сенсаціi); 
- новизна (повідомлення про найновіші факти з політичного, економічного, культурного чи наукового життя - завжди привертають увагу мас-медіа);

- успіхи (ідеться про успіхи країн, партій, лідерів, результати виборів, рейтинги популярності, культ зірок - у політиці, спорті, культурі);

- статусність (що вищий політичний, економічний чи духовний статус джерела інформації, то більше в нього шансів прозвучати в ефірі чи бути надрукованим на сторінках газети).

Мас-медіа можуть бути не тільки важливим засобом інформування населення. Досвід показує, що ЗМК активно використовуються правлячою політичною, економічною та духовною елітою суспільства для соціального та політичного маніпулювання.

А задля цього не тільки відповідним чином підбираються й підтасовуються факти, замовчується інформація, поширюється брехня, а й застосовуються прийоми напівправди, фрагментації в потрібному контексті інформації, навішуються ярлики $[16 ; 19 ; 24 ; 26]$.

I справді, скажімо, якщо людина веде збройну боротьбу за створення самостійної національної держави, іiї залежно від політичних симпатій можна назвати і терористом та сепаратистом, і партизаном та борцем за свободу. Якщо це наш, то "розвідник”, якщо не наш, то “шпигун” і т. ін.

Трапляються і певні ідеологічні (імперські) „парадокси”. Скажімо, комуністична пропаганда в СРСР називала Центральну Раду Української Народної Республіки “буржуазною”, хоча більшість у ній мали українські соціал-демократи. Але, згадуючи слова М. Грушевського, що російська соціалдемократія закінчується на українському питанні, ми розуміємо, що нічого дивного в цьому московському „парадоксі” й немає.

В основі таких підходів лежить використання методів соціальної міфології, яка активно впроваджується усіма можливими засобами в суспільну свідомість, насамперед через мас-медіа.

В цьому контексті варто назвати окремі особливості соціальної міфології, що використовувалися в недалекому минулому.

Наприклад, базовими (комуністичними) міфами колишнього Радянського Союзу були:

- приватна власність як головне джерело соціального зла;

- неминучість краху капіталізму та перемоги комунізму;

- керівна роль пролетаріату та його комуністичної партії;

- єдине правильне соціальне вчення - марксизм-ленінізм.

Де ці міфи нині? Чи домінують вони? Крах комуністичної ідеології та так званого соціалістичного табору показав "хто $є$ ким" [2;30].

Так само і в західному світі не все гаразд. I там більш до вподоби не раціональне осмислення політики, а використання соціальних міфів.

Ось, наприклад, поки що домінуючі базові (буржуазні) міфи США (за версією Г. Шиллера):

- про індивідуальну свободу і особистий вибір громадян;

- про нейтралітет найважливіших політичних інститутів - президента, кон- 
гресу, суду, ЗМК;

- про незмінно егоїстичну природу людини, ії агресію та споживацтво;

- про відсутність соціальних чи етнічних конфліктів;

- про плюралізм ЗМК та ін. [31].

Зрозуміло, ми ще станемо свідками руйнування цієї міфологічної системи (i нинішня глобальна економічна криза - лише початок цього природнього процесу чергової заміни міфологем).

Насамкінець зазначимо, що мас-медіа можуть бути приватними, державними та суспільно-правовими. А структура ЗМК в цьому контексті в кожній країні може бути різною.

Головне полягає в тому, щоб усі вони мали рівні права, а інформаційний простір не був надмірно монополізований. Лише тоді ми зможемо говорити про інформаційну владу як справді рівноправну четверту владу поряд із законодавчою, виконавчою та судовою. Звичайно, це ідеал. Але якщо не йти в цьому напрямі, ми обов'язково натрапимо на якийсь “...iзм”.

\section{Мас-медіа і громадська думка}

Масова комунікація пов'язана 3 видами інформаційно-комунікаційної діяльності, пов'язаної з використанням знаків і символів.

Ідеологеми, державна та політична символіка, правила етикету, мова жестів, дорожні знаки і т. ін. містять необхідну для соціалізації індивіда соціальну (політичну, економічну, духовну) інформацію.

У сучасному світі роль засобів масової комунікації постійно зростає. Нині вже нікого не здивуєш, назвавши мас-медіа четвертою владою (поряд із законодавчою, виконавчою та судовою). Хоча, звичайно, і перебільшувати ці впливи не варто.

У правовому демократичному суспільстві ці гілки влади мають бути незалежними, а розподіл влади повинен бути чітко виписаний в конституції країни. У противному разі виникають ситуації, коли гілки влади воюють одна 3 одною, використовуючи власні друковані органи (що, безумовно, не викликає захоплення у громадян).

Сучасна історія України має чимало таких прикладів, коли парламентський “Голос України” обмінювався з “Урядовим кур'єром” різкими заявами пресслужб Верховної Ради та Президента України (за часів президентства Л. Кучми).

3 науково-дослідницького погляду це можна назвати прикладами горизонтальної політичної комунікації, з погляду так званої традиційної демократії - нонсенсом, оскільки у розвинених країнах немає відомчої преси. А з погляду формування поваги пересічного громадянина до влади - взагалі безглуздям і недалекоглядністю, оскільки “пікірування" законодавчої та виконавчої гілок влади аж ніяк не сприяє зростанню довіри до влади взагалі, а підриває легітимний грунт держави й руйнує соціально-політичний баланс усередині суспільства.

Останній період новітньої української історії дав ще більш брутальні і недопустимі у цивілізованому світові приклади, коли найвищі керівники держави 
переходили до особистих образ, звинувачуючи один одного у злочинних діях (Ю. Тимошенко, В. Ющенко, В. Янукович).

Окрім горизонтальної політичної комунікації виокремлюють їі вертикальний різновид.

Якщо в першому випадку мають на увазі процеси обміну інформацією на рівні “індивід - індивід”, “суспільна група - суспільна група”, “держава - держава” і т. ін., то вертикальна політична комунікація передбачає інформаційні обміни між суб'єктами політики різної ваги: “держава - індивід”, “суспільна група - держава” і т. ін.

Зрозуміло, що взаємний вплив різновагових суб'єктів політики в комунікативних процесах є різним. Його можна дослідити й оцінити через різні концепції функціонування мас-медіа, які домінували і домінують у різні періоди розвитку сучасної цивілізації в окремих суспільствах:

- авторитарна концепція, що сформувалася у XVI-XVII ст. і визначала основне покликання преси - підтримка й сприяння політиці уряду та служіння державі [33];

- “правдива" концепція, грунтується на свободі волі та декларуванні таких цілей преси: інформування, продаж, сприяння дозвіллю та контроль за діями уряду (XVII ст., Д. Мільтон, Дж. Локк, Д. Мілль) [17];

- тоталітарна концепція, що виникла наприкінці ХІХ ст. (В. Ленін), зміцнилась у першій половині XX ст. (Й. Сталін, А. Гітлер, Й. Геббельс, Мао Цзедун) і передбачала необхідність ведення ідеологічної боротьби 3 класовим ворогом [2; 23];

- концепція соціальної відповідальності преси, яка утвердилась у середині XX ст. (Т. Петерсон, А. Катля, А. Каде та ін.) виходячи з таких цілей масмедіа: інформування, продаж, сприяння дозвіллю та переведення конфліктів у план дискусії [4].

Виходячи 3 цього неповного переліку концепцій функціонування мас-медіа, читачі самі можуть оцінити, яка саме концепція $є$ провідною в діяльності засобів масової комунікації в Україні.

Нас же в цьому контексті цікавить проблема політичного маніпулювання, яким так полюбляє користуватися правляча політична еліта, нав'язуючи свої стереотипи масовій суспільній свідомості через засоби масової інформації.

На нашу думку, політичне маніпулювання - приховане управління політичною свідомістю та поведінкою людей в певних політичних інтересах.

Цей спосіб соціального управління має певні переваги порівняно із силовими адміністративно-правовими й економічними методами панування, оскільки здійснюється непомітно для об'єктів управління, не потребує значних матеріальних затрат і жертв для встановлення контролю над суспільством.

Інформаційно-комунікаційні технології глобального маніпулювання грунтуються на вже згадуваних раніше базових соціальних міфах, що втлумачуються в суспільну свідомість за допомогою наступних способів маніпулювання:

- брехня - пряме, відверте підтасовування фактів і поширення брехні; 
- замовчування - блокування правдивої інформації щодо діяльності того чи іншого суб' єкта політики, події і т. ін.;

- напівправда - препарування інформації, яка об'єктивно та грунтовно висвітлює малозначущі деталі й водночас замовчує важливі факти та (або) неправдиво інтерпретує події;

- упровадження іміджів і кліше - укорінення в суспільну свідомість бажаних для правлячої еліти стереотипів щодо тих чи інших суб'єктів політики, ідеологічних доктрин, окремих подій та фактів;

- навішування ярликів - бездоказове нав'язування суспільству негативних (з погляду більшості) оцінних категорій 3 метою компрометації певних суб’єктів політики (партій, суспільно-політичних рухів, індивідів) на кшталт "імперіаліст”, “націоналіст”, “фашист”, “шовініст”, “антисеміт” тощо.

Звичайно вплив правлячої еліти на формування громадської думки за допомогою мас-медіа може бути досить ефективним.

Це можна дослідити під час проведення виборчих кампаній, коли іміджмейкери використовують безліч маніпуляційних прийомів, аби переконати громадян у тому, що їхній кандидат у президенти, депутати чи мери - найкращий.

Один із таких прийомів - “спіраль замовчування”, коли за допомогою сфабрикованих опитувань громадської думки або вибірково інтерпретованих результатів реальних опитувань мас-медіа намагаються переконати громадськість у підтриманні більшістю того чи іншого політика.

На фоні замовчування реального рейтингу опонентів голос так званої більшості роблять дедалі сильнішим. Відтак ті, хто ще не визначився у своїх політичних симпатіях, поволі схиляються до думки приєднатися до більшості, не бажаючи опинитись у соціально-психологічній ізоляції.

Використовуються й інші можливості політичної пропаганди, реклами та PR-технологій (наприклад, за допомогою всіляких шоу-заходів), коли раніше нікому не відомих кандидатів “розкручують” і просувають у політичні лідери.

Однак є певні обмеження об'єктивного та суб'єктивного характеру щодо політичного маніпулювання, які не дозволяють повністю перетворити вільний вибір громадян на формальний акт, запрограмований іміджмейкерами.

Згадаймо часи тоталітарної пропаганди в Радянському Союзі, коли вся пропагандистська машина була запрограмована на формування "гвинтиків" і бездушних соціальних роботів. Проте одночасно з офіційною політичною культурою розвивалася альтернативна контркультура андеграунду.

Чим же визначаються обмеження політичного маніпулювання?

Передусім ментальністю та політичною культурою суспільства, які хоча й не $\epsilon$ застиглими, проте й не такими динамічними, як би того хотілося соціальним технологам (у нашому випадку - маніпуляторам).

Крім того, варто згадати й системи комунікації, які навіть у тоталітарних суспільствах перебувають поза межами контролю влади: сім'я, родичі, знайомі, друзі, колеги по роботі, дозвіллю, хобі і т. ін. 
Важливим чинником обмеження можливостей політичного маніпулювання 3 боку правлячої еліти є суспільний контроль за інформаційною владою.

Найважливішим принципом демократичної організації мас-медіа $є$ плюралізм влади в суспільстві та плюралізм власне ЗМК.

Сучасний політичний досвід свідчить, що плюралізм мас-медіа може грунтуватися на таких формах організації ЗМК:

- комерційній, коли ЗМК перебувають у приватній власності й фінансуються за рахунок доходів від реклами і пожертв (США);

- державній, коли ЗМК належать державі, прямо фінансуються та контролюються нею (колишній СРСР, Китай, нинішня Франція);

- суспільно-правовій, коли ЗМК фінансуються переважно за рахунок спеціального податку, мають юридичні права та органи самоврядування, але загалом контролюються суспільними радами (телебачення та радіо в Німеччині) тощо.

Зрозуміло, що ідеальних форм організації ЗМК не існує. Очевидно, раціональним $\epsilon$ оптимальне співвідношення різних форм залежно від особливостей певної країни, звичайно, у поєднанні 3 ефективним контролем за діяльністю ЗМК, здійснюваним на правових засадах.

У більшості країн світу є спеціальні органи загального контролю за 3МІ, які стежать за виконанням етичних i правових норм, прийнятих у цьому суспільстві.

Наприклад, у Франції такою організацією є Вища рада по аудіовізуальній комунікації, яка не лише контролює державні й приватні телерадіокомпанії, а й видає їм державні ліцензії на право виходу в ефір.

У Великобританії загальні напрями діяльності телебачення й радіо визначають уряд і парламент, а за дотриманням етичних норм стежить спеціальна комісія з самоконтролю.

В Україні питаннями видачі ліцензії та контролю за дотриманням умов телерадіомовлення займається Національна рада 3 телебачення та радіомовлення, яка на паритетних засадах формується Верховною Радою та Президентом України і затверджується на сесії парламенту.

Насамкінець звернемо увагу й на освітньо-педагогічні та виховні функції системи мас-медіа, яка покликана сприяти формуванню свідомих громадян і домагатися масової політичної підтримки політики соціальних перетворень у межах конституційного процесу побудови демократичної правової соціальної держави.

\section{Мас-медіа як провідний соціальний інститут громадянського суспільства}

Однією з передумов формування громадянського суспільства, його політичного й інституціонального структурування, формування громадянської політичної культури та суспільної свідомості є відповідне соціально-інформаційне забезпечення цього процесу.

Одним 3 найвагоміших показників в цьому напрямі $є$ формування та інституціоналізація засобів масових інформаційних комунікацій. Досягнення сучасного суспільства в інформаційно-комунікаційній сфері створили принципово 
нову ситуацію в соціальній та політичній комунікації.

Індустріалізація й урбанізація суспільства, руйнування традиційних комунікацій і колективних цінностей, бурхливий зріст індивідуалізму привели до автономізації громадян, переважна більшість яких сьогодні одержує політичну i соціальну інформацію майже виключно від мас-медіа.

Сучасна людина на відміну від своїх предків дуже рідко знаходить можливість для звичайного спілкування і тим більше політичних комунікацій з оточуючими людьми, а часто навіть не знає сусідів. Усе це робить їі поведінку досить залежною від мас-медіа.

Одночасно ці нові чинники, обстановка постіндустріального чи інформаційного суспільства вносять важливі зміни у вже сформовані структури і відносини громадянського суспільства там, де воно існує не перше десятиліття, - у розвинутих західних країнах.

Аналіз політичної теорії, теорії демократії свідчить про позитивну взаємозалежність між стійкістю, цілісністю демократичного процесу, з одного боку, i здатністю громадян формувати добровільні суспільні асоціації, що поєднують людей навколо загальних цілей і сприяють активному залученню до розв'язання суспільно-політичних проблем - з іншого.

За справедливим зауваженням Р.Дала, демократія вимагає свободи вираження, яка необхідна, щоб громадяни могли ефективно брати участь у політичному житті. Для того, щоб прислухатися до думки інших, зрозуміти іiі, насамперед необхідно, щоб цю думку можна було почути [8].

Якщо ж усі джерела інформації контролюються урядом, то як у цьому випадку громадяни зможуть одержати відомості, необхідні їм для розуміння тих чи інших питань? Тому умовою формування громадянського суспільства, його розвитку і функціонування $є$ альтернативні джерела інформації, які не перебувають під контролем уряду і не служать інтересам якоїсь однієї групи.

Найвпливовіший із мас-медіа - телебачення, породжене, здавалося б, для зміцнення і розвитку громадянського суспільства, обертається чинником і знаряддям підриву системи соціальної та політичної комунікації суспільства.

Цей факт має стати застереженням для сучасної України. Громадянське суспільство в нашій країні перебуває ще на етапі становлення, а результати соціологічних опитувань уже фіксують лідерство „мильних” серіалів у рейтингах популярності подій останнього тижня.

За оцінками багатьох дослідників означеної проблеми, ці ЗМК не повною мірою відповідають потребам, очікуванням, ціннісним орієнтаціям, загальному рівню культури дорослого населення України. Зокрема, заслуговує на справедливі дорікання недостатній професійний рівень багатьох програм телебачення $\mathrm{i}$ радіо та публікацій у друкованих ЗМК.

Також слід зауважити, що значна кількість авторів програм та публікацій відрізняються політичною чи бізнесовою заангажованістю, наслідком чого стала відсутність різнобічності і плюралізму у висвітленні соціально-політичного життя українського суспільства. Як відомо, західні стандарти (звісно, в ідеалі) передбачають все-таки неупередженість ЗМК. 
Системна еволюція української суспільної сфери неминуче структурує медіапростір відповідно до напрямів формування соціальних інститутів. Нинішні ЗМК набувають ознак незалежних складових громадянського суспільства, їх інституціональні характеристики пов'язані з усуненням моноідеологічної цензури, що наочно свідчить про трансформацію масової комунікації з моностилістичної у полістилістичну.

Цей процес часто пов'язують із трансформацією інформаційнокомунікаційної сфери переважно на рівні організаційно-структурних змін, передовсім із роздержавленням преси, вбачаючи в цьому правову основу поняття незалежної преси [3; 25].

Власне, під роздержавленням ЗМК мається на увазі законодавче врегульований перехід прав засновника (власника) засобу масової інформації, а також прав контролю, управління і розпорядження ним у будь-якій формі від органів державної влади, а також підприємств, установ та організацій з державною часткою фінансування до недержавних суб'єктів та інституцій.

В сучасній Україні активну (може й занадто активну) участь у процесі розвитку та змін у функціонуванні ЗМК бере приватний капітал, власники якого розуміють роль і значення мас-медіа у громадському суспільстві.

Саме приватний, насамперед, зарубіжний капітал (i це $є$ загрозою для національних інтересів) стає засновником, видавцем багатьох мас-медіа в різних регіонах України, намагається підтримувати та створювати недержавні ЗМК, активно вивчати громадську думку, цілеспрямовано використовувати методи політичного маркетингу і менеджменту. У цих умовах мас-медіа стають вагомим інститутом громадянського суспільства України.

Отже, суттєвою ознакою інституціоналізації мас-медіа вважається набуття автономного статусу ЗМК. Найхарактернішими для сучасних мас-медіа в Україні стали процеси приватизації та комерціалізації преси. Сучасні ЗМК переважно функціонують за ринковими законами (особливо це стосується недержавної соціальної комунікації), проте, часто-густо в їхній діяльності домінують й певні політичні інтереси власників.

Всі ці процеси серйозно впливають на зміну структури ринку мас-медіа, що суттєво впливає на формування громадської думки та розширення ареалу впливу на політичні структури.

Передовсім декларується пріоритет політичної заангажованості преси, що здійснюється через наступні прояви:

- прямий прояв політичної, партійної, фінансової та іншої структурної незалежності медіа-представника, коли у вихідних даних зазначаються конкретні засновники та видавці;

- непрямий прояв своєї залежності, коли зазначені у вихідних даних організації структури залишаються латентними і лише аналітико-синтетична критика джерел дасть змогу виявити політичні, кланові складові заангажованості конкретного медіа-представника.

Прийнято вважати, що однією з ознак інституціоналізації мас-медіа $є$ набуття ними можливості структурованого впливу на аудиторію з метою формування 
електоральної поведінки. При цьому сам процес структуризації преси відбувається на тлі розвитку недержавного сектору суспільної сфери.

Вказана тенденція роздержавлення мас-медіа, безумовно, впливає на розмаїтість ставлення аудиторії до функціонування преси залежно від усталених думок, системи цінностей учасників інформаційно-комунікаційного процесу. Проте не варто й перебільшувати значення цього процесу як однієї з передумов формування преси як інституту громадянського суспільства.

Як слушно зауважив Дж. Кін: „...Давно минув час, коли можна було приймати на віру тезу, що ринкова конкуренція забезпечує свободу комунікації... Сьогодні ситуація протилежна: друзі „свободи друку” мусять збагнути, що саме ринок комунікацій обмежує свободу комунікацій. Коротше кажучи, з цього випливає глибинна суперечність між свободою комунікації та необмеженою свободою ринку" [12, с.102].

Об'єктивна потреба у формуванні інституту преси як складової громадського суспільства дозволяє конкретизувати подальший розгляд цього питання в частині законодавчого забезпечення зміцнення інституту незалежної преси. Проте реальний стан із свободою слова в інформаційному просторі держави розкриває доволі умовну незалежність преси.

Намагання законодавця вплинути на цю ситуацію лише через виписану в законі процедуру зміни власника дещо спрощує цю проблему, але не вирішує по суті даного питання.

3 метою реалізації інформаційних потреб суспільства журналістика звертається до висвітлення явищ та проблем усього соціуму. В такий спосіб преса охоплює різні галузі управління державними справами, а також впливає на діяльність інститутів громадянського суспільства.

Виходячи $з$ концепції суверенітету народу та формування на цій основі народної демократії видається логічним зробити висновок про те, що вся сукупність ЗМК - має бути засобами соціальної комунікації народу.

Саме так вважає Дж. Мерріл, котрий свідчить, що здоровою є „журналістика, що спирається на народ” і тому зобов'язана „публікувати матеріали, які об'єднують людей, а не роз'єднують», давати громадянам ,,те, що потрібне їм, а не те, що журналісти думають, що їм потрібно” [9, с.256].

I це не просто слова. За ними - філософія соціальних комунікацій, що повинна бути в основі будівництва громадянського суспільства.

Зокрема, зміна політичного режиму в українському суспільстві створила якісно інші соціально-політичні передумови для діяльності новостворених політичних партій та суспільних організацій, котрі отримали потенційну можливість здійснювати інформаційно-комунікаційні зв'язки політичних партій та громадських організацій із соціальними групами.

Продуктивність соціального діалогу в трикутнику мас-медіа - інститути громадянського суспільства - державні структури багато у чому залежить від реалізації органічної для народної журналістики ролі публічного контролера діяльності соціальних інститутів (державних та недержавних), посадових осіб, представників політичної еліти українського суспільства. Виконання такої 
функції засобами преси реалізується переважно методом журналістського розслідування.

Суть цієї діяльності висловив Дж. Робертс, який зауважив, що „мета журналістського розслідування полягає не в тому, щоб зненацька впіймати політика у непристойній ситуації чи виявити окреме порушення закону, а в тому, щоб віднайти глибоко приховані факти та допомогти читачеві в усвідомленні того, що відбувається в нашому складному світі” [28, с. 105].

Інформаційна реакція на журналістське розслідування у формі публічної відповіді на питання, що порушені представником соціуму - журналістикою, підвищує авторитет владних структур та довіру до журналістики як інституту громадянського суспільства. Навпаки, ігнорування виступів преси згубне для авторитету тих, хто не зважає на ЗМК, позбавляє їх суспільної підтримки. Це неминуче позначається, зокрема, на долі партій, на результатах виборів.

Такою $є$ сила суспільної думки, акумульованої та проголошеної через масмедіа. Отже, нормативне закріплення правил реакції на виступи ЗМК видається необхідним згідно з демократичними правами та свободами, визначеними в Конституції України.

Розглядаючи роль громадської думки в громадянському суспільстві, Дж. Ваттімо кваліфікує її як продукт механізмів інформації і соціальної комунікації, що $є$ явищем природним [5].

Переважно ця теза має реальне підгрунтя в демократичних країнах із розвинутими складовими громадянського суспільства, коли громадська думка усвідомлюється як консолідоване ставлення переважної частини суспільства до конкретних фактів дійсності.

Проте в багатьох випадках громадська думка виявляється на практиці вирішальною лише тоді, коли відповідає певним інтересам суб'єктів політичної діяльності, насамперед, політичних блоків і партій, які справляють постійний вплив на державу і формують урядову політику. В українському соціумі партії ще не набули ознак генератора соціальних інтересів, можливо, через те, що не опанували ЗМК у той спосіб, коли преса об'єднує інтереси партійних функціонерів і їх виборців.

3 огляду на це важливим $є$ питання про комунікаційні зв'язки преси 3 інститутами державної влади. В принципі вони $є$ рівними, оскільки кожний суб'єкт відносин представляє одну з рівноправних форм демократії: преса безпосередню, а три державних - представницьку. При нормальному функціонуванні суспільного організму ці відносини не можуть бути іншими, ніж партнерськими, що, зрозуміло, не виключає, а припускає і контроль 3 боку ЗМК, критику політики i дій влад, а також підтримку організованих ними кроків - все залежить від того, якими є результати моніторингу та аналізу, публічного обговорення проблем у ЗМІ.

Намагання влади посісти місце панівного суб'єкта політичної системи і вплинути на провідний за своїми мас-медійними можливостями інститут громадянського суспільства, яким є преса, викликає відповідно до законів політичної комунікації зворотну реакціює у формі тиску мас-медійних структур на владні інституції. 
В Україні доволі прозоро виокремлені групи медіа-представників, які чинять активний тиск на владу. Практика функціонування демократичних режимів свідчить, що важливою складовою демократизації суспільства є активна участь преси у прийнятті владних рішень. Водночас взаємозв'язок роботи влади і мас-медіа в системі соціальних інститутів не має одновекторного спрямування.

Це зумовлено природою ЗМІ, особливостями їх функціонування з урахуванням внутрішніх і зовнішніх впливів, значною мірою - механізмом прийняття рішень в ешелонах влади.

У мас-медіа формування груп тиску відбувається за рахунок ситуативної консолідації ЗМК, що віддзеркалюють інтереси різних соціальних прошарків.

Механізм тиску преси на владні структури реалізується таким чином:

- через оцінки в пресі моральних, особистих, ділових якостей об'єкта впливу, його діяльності, рішень, які він приймає;

- шляхом акумулювання інформації оцінного характеру 3 метою зміни дій об'єкта тиску до рівня системи цінностей, що його пропонують конкретні 3MI.

- завдяки використанню порівняльної моделі дій представників влади.

Для реалізації зазначеного механізму тиску на владні структури преса використовує максимально можливий інформаційний ресурс, оскільки неодмінною умовою ефективного впливу на владу має бути адекватний ій механізм одержання, опрацювання, аналізу, збереження і поширення інформації.

У цьому плані важливим чинником стає інформаційно-комунікаційна політика на міжнародному рівні, передовсім у частині використання джерельної бази, що містить оцінки дій українського політикуму, в тому числі і за кордоном. Адже ЗМІ, які ведуть відкритий діалог, є свого роду об'єднуючим осередком різних сил, що беруть у ньому участь.

Тут здійснюється процес комунікації з усіма іншими учасниками діалогу, їх позиціями і пропозиціями, аргументами і контраргументами, причому без вилучень, замовчувань, перекручень, нехай і мимовільних, але практично неминучих для 3МІ, що представляють інтереси окремих груп і партій, саме в силу їх ангажованості, задіяності на боці однієї з сил.

Окрім того, під час діалогу важливо врахувати всі складові позиції кожної сили, що втручається в конфлікт, чого часто не можуть робити репрезентанти точки зору лідерів думок.

Водночас треба взяти до уваги важливість права голосу в 3МІ тих, хто надає дискусії характеру масовості, широкої участі громадськості в соціальному діалозі засобами преси.

Отже, суспільству необхідні 3МІ, принципово орієнтовані на «відкритий діалог» $\mathrm{i}$, головне, здатні вести його конструктивно й ефективно. Сутність позиції таких ЗМІ полягає у здатності брати участь у соціальному діалозі 3 позицій, максимально наближених до загальнонаціональних, загальнолюдських цінностей завдяки прагненню врахувати інтереси всіх сторін у конфлікті і знайти прийнятне рішення. 
Якщо це так, то, очевидно, набуває ваги роль журналістики як «незалежного» соціального експерта і дистанційованої від держави «четвертої влади» у створенні конструктивних умов для центризму з метою формування могутніх соціальних шарів, їх ідеології та організації як складових громадянського суспільства.

У практиці неважко виявити деякі норми, що стосуються реакції державних інститутів на виступи ЗМІ. Водночас потрібні додаткові зусилля в напрямі формування системи юридичних норм, що фіксують місце «четвертої влади» в суспільстві. Однак проблема легітимації, зрозуміло, набагато ширша i складніша.

Докладне обговорення іï необхідно, і зробити це варто в дослідженні про норми діяльності мас-медіа при характеристиці категорій обов'язку, прав та відповідальності ЗМК як «четвертої влади» та фіксації описаних норм у законодавстві, етичних кодексах, правилах поведінки та взаємовідносин журналістських інституцій у громадянському суспільстві.

Отже, видається очевидним, що журналістика відповідно до своєї природи має специфічну різноманітну систему владних повноважень, що саме по собі дає підстави говорити про неї як вагому складову громадянського суспільства. Однак для того, щоб ці іiї повноваження здатні були проявитися точно, зосереджено і повною мірою, необхідно знайти шляхи і засоби розв'язання тих проблем, які накреслені. I від характеру теоретичного вирішення їх, закріплення в нормативно-правових документах, а потім і від просування цих норм в усвідомлену практику діяльності ЗМІ залежить успіх їх діяльності в умовах діалогової демократії XXI століття.

\section{PR суспільних організацій в системі масових комунікацій}

Паблік рилейшнз (PR) є, безперечно, феноменом сучасного суспільства, який на підставі високорозвинених інформаційно-комунікаційних технологій створює принципово нові можливості інформаційного контролю та впливу на суспільну свідомість.

Сам термін зародився ще в XIX ст. Зокрема автор Декларації незалежності і згодом президент США Т. Джефферсон у своєму “Сьомому посланні до конгресу” акцентував на тому, що без цілеспрямованих конструктивних відносин 3 громадськістю демократія є неможливою або принаймні важкою для реалізації. Політик мав рацію. Вже на початку наступного століття один з успішних PRменеджерів Е. Бернейс свідчив, що у 30 -х роках XX ст. термін "public relations" використовувався для означення “дій заради суспільного блага” [16, с. 12].

Етимологія цього поняття (існує понад 500 визначень), звичайно, не може не цікавити, але найбільше нас цікавить інституалізація і професіоналізація цього виду людської діяльності.

В цьому контексті варто згадати Римського Папу Урбана VIII, який, не вживаючи терміну паблік рилейшнз як такого, дуже розумів важливість інформаційно-комунікаційної діяльності у сфері боротьби за душі пастви. Розумів аж настільки, що заснував конгрегацію пропаганди (1633), яка, по суті, займалася зв'язками з громадськістю в сучасному розумінні цього терміна. 
Якщо відкинути формально-правові аспекти існування теологічної держави Ватикан, можна сміливо стверджувати, що католицька церква як глобальна суспільна (релігійна) організація була першою, що створила інформаційнокомунікаційну службу, а першими PR-щиками були професійні монахипропагандисти.

То ж чи варто дивуватися, що на початку XXI століття Ватикан використовує мобільні телефони для масової розсилки основних тез проповідей свого релігійно-державного лідера?

Але ця “перша ластівка не створила весни”. Довелося почекати аж до XIX ст., яке ознаменувалося появою подібних структур у державних і комерційних організаціях та установах. Отже, консервативна по своїй суті громадська релігійна організація виявилася навпрочуд модерновою як для свого часу! I не тільки для нього!

Процесс пішов. Майже водночас і в різних країнах.

Наприклад, Британське Казначейство (1809) та Британська поштова служба (1854) запроваджують посади прес-секретарів. У Німеччині фірма Круппа (1893) та міська влада Магдебурга (1906) створюють відповідно спеціальний відділ по роботі з пресою та міську прес-агенцію. У США Гарвардський університет створює бюро пабліситі (1900), Пенсільванський університет (1904) офіс пабліситі, а Айвер Л. Лі - першу службу PR (1903).

Поступово PR стає важливим елементом громадянського суспільства. Створюється перший спеціальний інститут PR у Великобританії (1948), “Суспільство PR” у США (1948), Міжнародна асоціація PR (International Public Relation Association (1955), яка об'єднує нині фахівців з 65 країн світу.

Iсторія PR як організованої форми діяльності свідчить, що без підготовки кадрів відповідної кваліфікації розвиток цієї сфери суттєво гальмується.

Тому й не дивно, що 1965 р. вже в 14 університетах США присуджувалися бакалаврські ступені, а нині вже більше двохсот американських університетів і коледжів готують фахівців з цієї спеціальності.

Зрозуміло, що підготовка такої кількості фахівців викликана наявністю відповідної кількості робочих місць. Наприклад у CШA PR-консалтингом займається більше 500 компаній, а обслуговують цей вид діяльності понад 250 тисяч рекламістів, більш як 130 тисяч журналістів і майже 10 тисяч фахівців з комунікацій [1].

Знаючи, що досить багато людей займається цією справою, варто детальніше зупинитися на суті зазначеної діяльності. Але, на нашу думку, потрібно використовувати поняття не “зв'язки з громадськістю”, а “громадські зв'язки”, якщо передбачати рівноправність суб’єктів комунікації у глобальному сенсі.

В цьому випадку будемо розуміти під громадськими зв'язками комунікаційні зв'язки між:

- суб'єктами громадянського суспільства;

-суб'єктами держави і громадянського суспільства;

- суб'єктами держави.

Найпоширеніші нині варіанти використання терміна паблік рилейшнз пов'язані з активною роллю суб'єкта, який намагається покращити свій імідж. I 
тоді громадськість розглядається як об'єкт впливу і маніпуляцій, а власне комунікаційний процес - як несиметричний процес передачі інформації з переважанням інтенсивності передачі інформації від суб'єкта до об'єкта комунікації. Навіть якщо інформація деякою мірою і надходить у зворотному порядку.

Якщо ж інформація передається тільки в одному напряму, тут, очевидно, втрачає сенс використання як терміна “громадські зв'язки”, так і терміна “зв'язки 3 громадськістю”, оскільки ключова функція власне “зв”язку” попросту зникає.

Відповідно до усталених у науковому товаристві підходів до цього терміна (з акцентом на “зв’язки $з$ громадськістю”), на думку Д. Ольшанського, під паблік рилейшнз розуміють спеціалізовану діяльність відповідних підрозділів державних, корпоративних, політичних, громадських, економічних та інших структур, спрямовану на посилення відкритості, взаємної інформованості і створення ілюзї взаємозалежності між структурами, які здійснюють PR, i суспільством, населенням, групами людей, на яких спрямована ця діяльність [16, с. 400].

На відміну від попереднього автора, Г. Почепцов вважає паблік рилейшнз наукою, що займається організацією комунікаційного простору сучасного суспільства [21, с. 28].

Очевидно, не зовсім праві і Д. Ольшанський, який відмовляє в існуванні науці паблік рилейшнз взагалі (себто, це виключно діяльність) і Г. Почепцов, який вважає, що ця наука займається організацією комунікаційного простору (наука досліджує, вивчає, аналізує тощо, але аж ніяк не організує).

На нашу думку, паблік рилейшнз треба розглядати як:

1. Царину наукових знань, що досліджує інформаційно-комунікаційну сферу суспільства в контексті контролю та маніпулятивного управління суспільною свідомістю.

2. Спеціалізовану галузь менеджменту інформаційно-комунікаційної сфери суспільства, яка спрямована на організацію і відносну гармонізацію комунікаційних зв'язків у суспільстві 3 метою підвищення ефективності функціонування інститутів держави і громадянського суспільства.

Певною мірою можна стверджувати, що як наука паблік рилейшнз ще перебуває в стадії становлення і накопичення технологічного і практичного досвіду. Водночас, спираючись на розробки психології (психології масових комунікацій та політичної психології), політології, соціології, інформатики (прикладної та соціальної), маркетингу, лінгвістики, семіотики, журналістики, герменевтики, віртуалістики та інших суспільних наук, паблік рилейшнз вже має свій об'єкт і предмет дослідження і певне методологічне і методичне підгрунтя.

Насправді паблік рилейшнз пов'язані із соціальною комунікацією, є масовими за масштабами, завданнями та способами поширення за допомогою ЗМК.

Рівночасно міжособистісні механізми впливу на людей дають певні підстави вважати PR видом маркетингової комунікації.

Проте в психологічному плані, на відміну від комерційної реклами та інших видів маркетингової комунікації, PR практично не користується методами прямого впливу на психіку людей. 
До того ж на рівні нюансів PR створює такий контекст, який підштовхує людей до думок в необхідному напрямі. Це дозволяє простіше проходити бар'єри психологічного захисту без використання прямого впливу і переконання.

Залежно від інтелектуального рівня об'єктів паблік рилейшнз можна виокремити такі рівні PR-впливу:

I рівень (відносно несамостійно мислячі люди - більшість), коли не потрібно вживати методів особливо тонкого впливу, і елементарний бізнесовий PR наближається до реклами, а політичний - до пропаганди;

II рівень (лідери думок), коли використовується опосередкований $\mathrm{PR}$, який діє хитро і замасковано;

III рівень (еліта), коли використовується тонкий, рафінований $\mathrm{PR}$, що діє дуже м'яко, напівнатяками, і навіть не твердженнями, а запитаннями і роздумами. Об'єднує всі ці рівні один психологічний підхід: людина під впливом PR все робить сама.

I це зовнішньо виглядає як м'який засіб переконання, що має наслідком досить жорсткий спосіб впливу, оскільки людині здається, що вона сама ухвалює рішення і сама ж несе за нього відповідальність.

Якщо порівнювати PR і журналістику, то можна відзначити, що журналістика описує події, а PR їх створює. Зрозуміло, що згодом PR-акції знаходять кероване висвітлення в засобах масової комунікації.

Основний продукт масової комунікації - віртуальна реальність, яка складається з природних і штучно сконструйованих іміджів. Але не можна ототожнювати іміджмейкінг і PR.

Іміджмейкінг, на думку Д. Ольшанського, $є$ процесом створення певного “матеріалу”, а $P R$ - управління каналами поширення таких матеріалів [16, с. 417].

Як наслідок, можна говорити про PR як опосередковане управління засобами масової комунікації, а відтак - й іміджами.

При цьому найефективніший варіант такої діяльності полягає не стільки в корегуванні існуючих іміджів (в кращий або гірший бік), скільки за рахунок фонових маніпуляцій (візуальних чи аудіальних).

Керуючи засобами масової комунікації шляхом маніпуляції семантичним простором (“соціалізм”, “комунізм”, “глобалізм”, “демократія”, “патріотизм”, “антисемітизм”, “націоналізм” тощо, PR використовує різноманітні технологічні і технічні прийоми.

Серед них маніпуляція “порядком денним” (робочій день президента), “розкрутка теми”, “задушення теми”, “вигідні контексти” та ін.

Остання маніпулятивна технологія $є$ найнебезпечнішою, оскільки на основі створення вигідних контекстів (понять, образів, уяв) на рівні підсвідомості, свідомість згодом сама буде “додумувати” те, що підкаже підсвідомість.

PR є невід’ємною складовою сучасної інформаційно-комунікаційної сфери суспільства, що глобалізується і набуває рис віртуальної реальності. Остання ж потребує систематичної роботи із засобами масової комунікації.

Ми навмисно не „розводили” проблеми здійснення комунікацій між структурами громадянського суспільства і держави, між ними і громадянами і т.ін. 
Вся справа полягає в тому, що з точки зору інформаційно-комунікаційного менеджменту та його невід”ємної частини, що зветься паблік рилейшнз, не має принципово технологічного значення, кому конструююється і „ставиться” в суспільній свідомості імідж: президенту, парламенту, професійній асоціації політологів або об'єднанню бджолярів.

\section{СПИСОК ДЖЕРЕЛ}

1. Бебик В. Інформаційно-комунікаційний менеджмент у глобальному суспільстві: психологія, технологї, техніка паблік рилейшнз. - К., 2005.

2. Бебик В. Політологія для політика і громадянина. - К., 2004.

3. Бебик В., Сидоренко О. Засоби масової інформації посткомуністичної Украӥни.- К., 1996.

4. Буржуазные теории журналистики: критический анализ. - М., 1980.

5. Ваттимо Дж. Прозрачное общество. - М., 2002.

6. Власенко Н. А., Зорько С. В., Сиротич М. Р. Україна на шляху до інформаційного суспільства: проблеми та здобутки. Інформаційноаналітичний огляд Національного інституту стратегічних досліджень. - K., 1995. - № 5 .

7. Гол Дж. Онлайнова журналістика / Пер. з англ. - К., 2005.

8. Дал Р. О демократии. - М.: Аспект Пресс, 2000. - С. 96.

9. Денис Э., Мэрил Дж. Беседы о масс-медиа. - М., 1997.

10.Жиляєв І.Б. Інформаційно-комунікаційні технології, як державний приоритет// Проблеми науки . - 2003. - №8. - C.3.

11.Кін Дж. Громадянське суспільство. Старі образи, нове бачення. - К., 2000. - C.51.

12.Кін Дж. Мас-медія і демократія / Пер. з анг. - К., 1999. - C.102.

13.Корнхаузер В. Політика масового суспільства // Політологічні читання.-1992.—№ 1 .

14.Лалл Джеймс. Мас-медіа, комунікачія, культура: глобальний підхід. - К., 2002.

15.Овчаров А. Вплив сочіально-психологічних технологій на сочіальне середовище // соиіальна психологія. - 2008. - №6.

16.Ольшанский Д. Политический PR.- СПб., 2003.

17.Орбан-Лембрик Л. Соціальна поведінка як спосіб вияву активності особистості // Соціальна психологія. - № 5. - 2004. - С. 12-19.

18.Остороухов В., Петрик В. До проблеми забезпечення інформаційної безпеки Украӥни // Політичний менеджмент. - 2008. - №4.

19.Попов Н. Индустрия образов. Идеологические функции средств массовой информации в США. - М., 1986.

20.Поршнев Б. Сочиальная психология и история. - М., 1979.

21.Почепцов Г. Паблик рилейшнз для профессионалов. - К., 2001.

22.Почепияов Г. Теорія комунікачії. - К., 1996.

23.Почепцов Г. Тоталитарный человек. -К., 1994. 
24.Присяжнюк М. Використання нейролінгвістичного програмування для маніпулювання свідомістю // Соиіальна психологія. - 2008. - №5.

25.Проблеми роздержавлення засобів масової інформачії в Україні. - K., 1998. - C. 16-27.

26.Різун В.В. Правда і кривда: історія взасмин з точки зору медіа освіти // Соиіальна психологія. - 2008. - №2.

27. Соколов А.В. Общая теория сочиальной коммуникации.- СПб., 2002.

28. Тертычный А.А. Расследовательская журналистика. - М., 2002.

29. Уледов А. Общественная психология и идеология. - М., 1985.

30.Хайек Ф. Пагубная самонадеянность. Ошибки соииализма. - М., 1992.

31.Шиллер Г. Манипуляторы сознанием. - М., 1980.

32. Щербина В. Сітьова кіберкомунікація як соиіальний феномен // Соиіологія: теорія, методи, маркетинг. - 2002. - №1.

33.Adorno Th. W. The Autoritarian Personality. - N.Y., 1950.

34.Almond G. Comparative Political Systems // Journ. of Politics. - 1956. Vol. 8.

35.Benigar J. R. Control Revolution: Technological and Economic Origins of the Information Society. - Cambridge, 1986.

36.Broder D. How Press Secrecy Backfired on Reagan // Washington Post. 1987. - 22 March.

37. Carey J. Communication of Culture: Essays on Media and Society. - Boston, 1980.

38.Entman R. M. Democracy Without Citizens: Media and the Decay of American Politics. - N. Y., 1989.

39. Habermas J. The Structural Transformation of the Public Sphere. - Cambridge, 1989.

40. Handbooks of Administrative Communication. - N. Y., 1997.

41.McLuhan M. Understanding Media. The Extension Men. - London, 1969.

42.McQuail D. Media Performance: Mass Communication and the Public Interest. - London, 1986.

43.Patterson B. H. Jr. The Ring of Power: The White House Staff and it's Expanding Role in Government. - N. Y., 1988.

44.Powell J. The President and the Press. - Washington: D. C., 1981.

45.Reedy G. The White House: The Media and the Man in the Middle // Three Press Secretaries on the Presidency and the Press. - Lanham, 1983.

46.Sabato L. J. Feeding Frezy: How Attack Journalism Has Transformed American Politics. - N. Y., 1991.

47.Schram M. The Great American Video Game: Presidential Politics in the Television Age. - N. Y., 1987.

48.Schwartzenberg R.-J. Sociology Politique. - P., 1988. - P. 42.

49. Spear J. C. Presidents and the Press: The Nixon Legacy. - Cambridge, 1984.

50.Wurman R. S. Information Anxiety. - N. Y., 1989. 


\section{2. СОЦІАЛЬНІ КОМУНІКАЦІЇ В УМОВАХ ІНФОРМАЦИЙНОГО СУСПІЛЬСТВА: ПАРАДОКСИ РОЗВИТКУ}

Екскурс в історію теоретичних прогнозів, які сповіщали про зародження інформаційного суспільства як нової стадії цивілізації, дозволяє виділити в зарубіжній комунікативістиці три стадії вивчення цього процесу. Якщо на першому етапі вивчення все зростаючої ролі інформаційно-комунікативних чинників розвитку суспільства перепліталось 3 концепціями постіндустріального капіталізму, (як, наприклад, в роботах Д. Белла [14]), то на другому висуваються ідеї розвитку моделей саме інформаційного суспільства, підгрунтям якого стає розвиток нової комп'ютерної техніки (М. Кастельс [6], Е. Тоффлер [11]). I лише на третьому етапі в 90-ті роки минулого століття акцент переноситься 3 «практичного» уславлення достоїнств «мережевого світопорядку» на соціальноісторичне прогнозування реальних переваг і труднощів переходу до інформаційного суспільства, на специфіку цього процесу в національних та міжнародних контекстах.

Композиція того, що сьогодні прийнято називати «інформаційним суспільством» розроблялась західними дослідниками, а сам термін практично одночасно ввели в науковий обіг США і Японії Ф. Махлуп та Т. Умекао [див.: 16]. Контури майбутнього суспільства вимальовувались головним чином у зв'язку 3 удосконаленням засобів розповсюдження та забезпечення доступу до інформації, зокрема, його технологічним, економічним, інфраструктурним аспектам. Саме ж «інформаційне суспільство» тлумачилось як таке, в якому завдяки комп'ютеризації людям полегшується доступ до джерел інформації, а за рахунок автоматизації вони будуть позбавлені від рутинної роботи, а сам продукт виробництва стане більш «інформаційно ємким», тобто в його вартості збільшиться частка інновацій, дизайну, маркетингу.

Таким чином, перехід до інформаційного суспільства виглядає як закономірний підсумок об'єднання двох процесів, що до цього паралельно розвивались протягом всієї історії людства: постійного зростання ролі та збільшення обсягів інформації, необхідного для забезпечення життєдіяльності суспільства, і процес розвитку та удосконалення технологій накопичення та розповсюдження інформації. В результаті саме «виробництво інформаційного продукту, а не продукту матеріального перетворилось на рушійну силу формування і розвитку суспільства» $[17,64]$.

Ідею взаємозв'язку та взаємообумовленості цивілізаційного та інформаційного процесів висунув у своїх працях Д. С. Робертсон, який знайшов для цього точну і ємку формулу: «Цивілізація - це інформація». Використовуючи кількісні виміри математичної теорії інформації, вчений ранжує основні етапи цивілізаційного розвитку за критеріями кількості інформації, що продукувалась у різні часи:

- рівень 0: інформаційна ємкість кожної окремої людини - $10^{7}$ біт;

- рівень 1: усне спілкування всередині роду, племені, громади - циркулює $10^{9}$ бiт; 
- рівень 2: письмова культура, виміром обсягу інформації, що розповсюджується у цей час, може служити Олександрійська бібліотека, рукописи та пергаменти якої містили $10^{11}$ біт;

- рівень 3 - книжкова культура, при якій сукупна ємкість носіїв інформації становила $10{ }^{17}$ біт;

- рівень 4 - інформаційне суспільство з електронною обробкою інформації має сукупний об'єм $10^{25}$ біт [ див.: 19, 37].

Наведена схема наочно демонструє, що «інформаційне суспільство» це така форма організації життя соціуму, при якій не лише стрімко зростають обсяги інформації, але вона проникає у всі сфери його життєдіяльності.

Однак у такому вигляді у поняття «інформаційне суспільство» є один суттєвий недолік - воно недостатньо зорієнтоване на аналіз соціальної структури суспільства.

Цей недолік до певної міри усуває концепція «мережевого суспільства» («віртуального суспільства»), висунута американським теоретиком М. Кастельсом, за якою ядром такого суспільства стає нова комунікаційна організація, в основі якої вже не інформація сама по собі, а мережева логіка його базисної структури. Новий тип суспільного порядку фахівець називає «мережевим», щоб підкреслити провідну роль комп’ютеризованих інформаційних ліній зв'язку, які вже пронизують соціальну тканину суспільства у всіх напрямках.

М. Кастельс розглядає таким чином соціальну структуру, що формується у глобальному масштабі, як суспільство, «найважливішою рисою якого є навіть не домінування інформації чи знання, а зміна у напрямках їх використання, у результаті чого головної ролі у житті людей набувають глобальні, «мережеві» структури, що витісняють колишні форми особистісної та матеріальної залежності» [6, 293].

У суспільстві інформаційної ери домінуючі функції і процеси все у більшій мірі виявляються організованими за принципом мереж. На зміну відносно жорстким і вертикально зорієнтованим структурам минулого приходять гнучкі і горизонтально зорієнтовані мережі, через які власне і здійснюється обмін ресурсами, політичний процес і таке інше. Звідси висновок: саме мережі складають нову соціальну міфологію сучасних співтовариств, а розповсюдження «мережевого» мислення у значній мірі позначається на повсякденному житті кожної людини.

Всесвітня комп'ютерна мережа, що утверджує інформацію як мету і засіб існування суспільства і завдяки цьому проникає у всі його сфери, перетворюється на головну його структуру. Необхідно зазначити, що мережевий принцип існування соціальної організації існував і раніше, але він не мав такого могутнього технологічного оформлення. В нинішніх умовах зміцнений всесвітньою комп'ютерною мережею, цей принцип починає творити новий соціальний простір-час, тобто починає впливати на фундаментальні підвалини соціального буття. Замість колишнього «простору місць» утверджується «простір потоків», а замість часу, що чітко розділений за поясами, приходить «позачасовий час» [див.: 6, 70]. 
Як вважає більшість фахівців, новий тип соціального простору-часу знаходить найбільш яскраве втілення у віртуальній реальності Інтернету. Винайдення телеграфу у XIX столітті і висока частота комунікаційних засобів зв'язку і передачі даних у XX столітті, починаючи з телефону і закінчуючи комунікацією за допомогою комп'ютера, означає відділення телекомунікації від транспортних технік. У цьому випадку розповсюдження комунікації більше не залежить від використання шляхів, створених для транспортування людей і товарів. Тим самим великі дистанції більше не створюють проблему не синхронності і більше того, стають сумісними $з$ глобальною одночасністю подій. Разом 3 переходом всього в цифрову форму природна і соціальна реальності починають поступово набувати свого віртуального виміру. Найважливіше у цьому процесі те, що вперше в історії людства простір охоплений єдиною структурою, що означає його підпорядкованість єдиній (мережевій) логіці розвитку і функціонування.

Якщо раніше «мережеві» суспільні структури і зустрічались (общини в первісну епоху чи малі соціальні групи у наступні періоди), то лише як підструктури домінуючої немережевої соціальної структури (після розпаду первісного співтовариства то була в основному ієрархічна та ринкова система соціальних зв'язків). Нині вперше формуються передумови «мережевого суспільства» (замість «мережевих співтовариств» у минулому). Всі інші типи соціальної структури, у тому числі ієрархія та ринок, знижують свій соціальний статус до залежних підструктур нової всеоб'ємної структури.

М. Маклюен розглядав сучасний соціокультурний простір як такий, в якому об'єднуються «всі часи і простори одразу» $[8,25]$. Цей вислів по-різному тлумачать інші науковці. У М. Кастельса використовується словосполучення «безчасовий час», за допомогою якого він намагається по-особливому відзначити той факт, що віднині минуле, сучасне і прийдешнє не зв'язані послідовністю, що вони практично злились воєдино. Відбувається надзвичайне «стистення» соціального часу (відомий вислів - «час - це гроші» чітко фіксує цей соціальний процес) аж до його анігіляції.

М. Кастельс, який детально аналізує феномен «віртуального часу», стверджує, що в інформаційному суспільстві час не лише стискується, але й певним чином «обробляється». Він виділяє дві форми трансформації уявлень про час у мультимедійній культурі, які виникають як наслідок одночасної трансляції великої кількості повідомлень різними каналами зв'язку та із колажного об'єднання в гіпертекстових потоках, що надають образам цієї інформаційної культури, з одного боку, безперервного характеру, а з іншого, - роблять їх ефемерними [див.: 6, 67-69].

Російський фахівець Д. В. Іванов, відповідаючи на запитання, чому основним феноменом Комп'ютерної революції став Інтернет, а не, наприклад, гігантські електронні банки даних чи штучний інтелект, приходить до парадоксального, на перший погляд, висновку: «В Інтернеті не створюється жодне знання, проте він безмежно розширює можливості здійснення комунікації» [4, 37].

Можливо, науковець і не зовсім точний, адже справді безкінечна інформація, яка накопичується у банках даних Всесвітньої Мережі, рано чи пізно сама 
по собі може надати нову якість викладеним в ній знанням, проте не можна не визнавати, що він має рацію, коли вказує на фундаментальну обмеженість нинішнього етапу розвитку Інтернету. Мережа справді механічно передає інформацію, та сама поки що не здатна продукувати їі. У цьому сенсі Комп'ютерна революція - це лише один з факторів сучасних суспільних змін, а мережева організація суспільства - альтернативна, але не єдина можливість для подальшого розвитку соціуму.

Говорячи про особливості соціалізаторської ролі комунікації в сучасному суспільстві, вчені зазвичай використовують теоретичну схему іiі взаємодії з різними рівнями соціуму. Ю. Левада виділяє три рівні цієї взаємодії: рівень особистості, рівень соціальної групи та рівень соціальних інститутів [7, 64].

Особистість завдяки і за допомогою масової комунікації самоутверджується, гармонізується іiі взаємовідносини в соціальній групі. Вона вчиться відповідати тим соціальним ролям, які актуалізуються, «нав'язуються» їй системою масової комунікації. Таким чином завдяки навчанню та соціалізації здійснюється залучення індивіда до культури суспільства.

У мережах, які використовують групи людей, новітні засоби масової комунікації сприяють їх соціальній та професійній інтеграції, залученню у більш широку соціальну структуру.

Якщо перейти на рівень соціальних інститутів, то саме засобам масової комунікації вони завдячують тим, що розповсюджувані ними соціальні норми стають доступними окремим особистостям, завдяки чому створюється активне мобілізуюче соціальне середовище 3 емоційними, раціональними та оціночними координатами.

Однак всі ці рівні об'єднуються однією властивістю мережевого простору, в якому тепер і здійснюється масова комунікація: він набуває віртуального характеру.

Про віртуалізацію стосовно суспільства можна говорити у тій мірі, в якій воно стає схожим на віртуальну реальність, тобто може бути описане за допомогою тих же параметрів. Віртуалізація у цьому випадку - це будь-яке заміщення реальності іiі симуляцією («симулякрами», за термінологією Ж. Бодрійяра $[1,23])$, образом (і не обов'язково за допомогою комп'ютера, але обов'язково виходячи з логіки віртуальної реальності). Подібну логіку можна спостерігати і там, де комп'ютерна техніка безпосередньо не використовується. Наприклад, віртуальною економікою можна назвати і ту, в якій господарчі операції проводяться, головним чином, через мережу Інтернет, i ті, в яких спекуляції на фондовій біржі переважають матеріальне виробництво. Теж саме можна сказати і про інші сфери. До віртуальної політики можна буде віднести не лише ту, де боротьба за владу ведеться за допомогою агітації, розміщеної на webсторінках чи оприлюдненій під час Інтернет-конференцій, а й таку, де домінують рекламні акції в телестудії чи на концертному майданчику.

Вже згадуваний Ж. Бодрійяр та інші західні теоретики (М. Паетау, А. Бюль, А. Крокер, М. Вейнстейн) вважають, що визначення соціальних феноменів через поняття віртуальності повинно мати місце тоді, коли конкуренція образів 
підміняе конкуренцію інституціонально визначених дій - економічних, політичних та інших. Соціальний зміст віртуалізації полягає в тому, що симуляція інституціонального ладу суспільства у цьому випадку стає первинною відносно змісту технічного. Іншими словами, не суцільна комп'ютеризація життя віртуалізує суспільство, а віртуалізація суспільства комп'ютеризує життя [див.: 9, 484].

Саме тому розповсюдження технологій віртуальної реальності російський дослідник Д. Іванов дотепно назвав «кіберпротезуванням», яке породжується бажанням компенсувати за допомогою комп'ютерних симуляцій відсутність справжньої соціальної реальності $[6,374]$.

Віртуалізація домінує сьогодні на всіх соціальних рівнях - індивідуальному, груповому, суспільному. Стійка і об'єктивна реальність ставала соціальноісторичною завдяки системі певних інститутів. Відчуження людини від такої реальності і було актом іiї соціального самоствердження та соціальної самоідентифікації. Перетворення в останні десятиліття цієї реальності у віртуальну змушує індивіда жити не в світі речей (тобто тим, що $є$ насправді), а в світі образів (тобто зображеному). А це призводить до того, що відносини між людьми все частіше набувають форми відносин між образами, що призводить до визначення старого і нового типів соціальної організації за допомогою дихотомії «реальне - віртуальне».

Завдяки впливові комунікації на окремі соціальні групи (аудиторії) формується характер суспільства. Віртуалізація цього процесу визначається тим, що на часі практично всі свої соціальні вчинки та рішення як окрема людина, так і цілі аудиторії «звіряють» із ЗМК. Більшість концепцій, що характеризують місце ЗМК в сучасному суспільстві («порядку денного», фреймінгу, дворівневої комунікації тощо), акцентують увагу на змістові медіа повідомлень і при формуванні думок про особи кандидатів на тих, чи інших виборах, і при виборі іміджу товарного бренду та багатьох інших явищах. Особистого досвіду або елементарного часу для цього у людини зазвичай не вистачає, тож ЗМК (як найбільш близькі, доступні та розповсюджені джерела інформації) починають відігравати в процесі соціально важливого вибору вирішальну роль [див.: 13, 86].

Розширення доступу до технологій, що значно посилює диверсифікацію каналів, послуг, а також змісту, яку ми спостерігаємо останні десятиліття, змушує нас зробити деякі парадоксальні висновки, вказати на явні протиріччя, з якими людство має справу чи не кожен день. Голандський вчений Я. ван Куйленбург, говорячи про медіарізноманіття (media diversiti), що, як вважає у своєму словникові концепцій і термінів Л. М. Землянова, співвідноситься з терміном «culture policy» [3, 91 підкреслював: «ми спостерігаємо певну експоненціальну диверсифікацію, яка може буде зведена до формули трьох «С»-diversification = Content, Carriers, Channels (зміст, поставщики, канали)» [15, 79-80]. Парадокс же цієї формули полягає в тому, що різноманітність каналів змушує говорити про доступність інформації. З'являються нові форми дефіциту. Ми буквально тонемо в інформації, але відчуваємо нестачу знань. 
На думку Нобелівського лауреата, економіста Г. Саймона, сьогоднішня «інформація знищує і поїдає увагу своїх споживачів (реципієнтів)» [цит. за: 10,72]. Звідси інформаційний та комунікаційний парадокс: багато інформації = мало інформації. В таких умовах навіть найновіші технології для продукування та розповсюдження інформації безсилі, бо вони не можуть бути доступними для всіх, а інформація не буде відфільтрована.

В умовах інформаційного парадоксу йде перевантаження споживачів (особливо дітей та підлітків) інформацією, у зв'язку з чим виникає дефіцит уваги. Масив Інтернет-сайтів, величезна кількість супутникових та кабельних каналів ТБ, які, як правило, вибираються легким натискуванням на відповідну кнопку пульту, в цілому, як не дивно, не дають людині зосередитись на чомусь конкретному. Тому у цих випадках таким важливим $€$ інформаційний відбір, а в окремих ситуаціях і повна відмова від користування новою інформацією.

До речі, дефіцит уваги виникає ще й як результат відсутності навичок традиційного читання. Нові покоління поступово відмовляються від звички читати, шо в умовах інформаційної дифузії, яка панує зараз у світі, призводить до втрати вмінь розуміти й аналізувати інформацію, знаходити потрібне у різних видах ЗМК.

У зв'язку з цим особливої уваги набуває спостереження видатного німецького теоретика М. Вебера, який одним 3 парадоксів еволюції суспільства вважав появу двох видів самоідентифікації особистості: індивідуацію та індивідуальність. Суспільство, що ще на порубіжжі XVIII-XIX століть стало «атомарним», тобто розпалось на певну сукупність індивідів, продовжує тримати в полі зору кожну окрему людину, створюючи ії особистий послужний список. Це і є індивідуація - відмінності однієї людини від інших за формальними, поверхніми ознаками.

Індивідуальність - а саме їй, на думку аналітика, загрожує зміцнення соціальної організації та суспільний моніторинг, що супроводжує це зміцнення, - це здатність розпоряджатись власною долею, поводити себе незалежно, контролювати течію власного життя [див.: 2, 415].

Інтернет, який став середовищем розвитку віртуальних спільнот альтернативних реальному суспільству, загрожує людині втратою індивідуальності, точніше підміною реальної ососбистості сконструйованою та трансформованою віртуальною особистістю. Спілкування через Інтернет для багатьох якраз привабливе своімм знеособлюванням, що і призводить до часто незворотної трансформації особистості як неповторної індивідуальної характеристики і особистості як соціокультурного феномену. Такі особливості як стабільна самоідентифікація, індивідуальний стиль реалізації соціальних ролей («творча індивідуальність») активними користувачами Інтернету практично втрачаються. Хочуть вони того чи ні, але в процесі віртуального спілкування ними формується розмита нечітка ідентичність. Іншими словами, віртуалізуються не лише суспільні відносини, але й особистості, 3 яких складається соціум [див.: 2, 412].

Бурхливий розвиток новітніх комунікацій висвітлив ще одну соціальну проблему. Сучасна людина, яка живе у світі глобальних інформаційних потоків, 
вже не впевнена у своїй інформаційній свободі та безпеці, як це було раніше. 3 подальшим розвитком інформаційного суспільства наслідки комунікаційних процесів, що відбуваються у сфері ЗМК, стають все більш очевидними: «старі» ЗМІ переходять в Інтернет, збільшується число каналів цифрового ТБ, розвивається мобільний контент, що зменшує значення колишньої регуляторної функції держави, а, значить, залишає людину сам-на-сам 3 новітніми засобами комунікації.

Натомість активність незнаних раніше аудиторій, депрофесісналізація журналістики та послаблення впливу національних держав на діяльність ЗМК стають ключовими характеристиками сучасного медійного простору. В цих умовах проблема інформаційної безпеки аудиторії набуває все більшої актуальності.

В інформаційному суспільстві, яке побудоване на використанні інформаційно-комунікаційних технологій у всіх сферах життя, найважливішим принципом комунікації та взаємодії різних інститутів, структур і людей стає мережевий принцип. На думку М. Кастельса, «користувачі (технології) стають іiї головними творцями, пристосовуючи іiі до своїх власних потреб та системи цінностей, що кінець-кінців призводить до трансформації самої технології» $[6,16]$. Висновок М. Кастельса про новаторство користувачів, на якому він акцентує увагу чи не в кожній роботі, надзвичайно важливий саме для інформаційної епохи $[6,72-73]$.

Незважаючи на важливу роль, яку зберігають за собою держава та великий бізнес у розвитку інформаційного суспільства, саме громадянське суспільство набуває набагато більшої, ніж раніше, свободи слова, переймаючи не себе і нову частку відповідальності за реальне використання технологій. Майбутнє інформаційного суспільства у все більшій мірз залежить нині від довіри людей до цифрових інтерактивних технологій, інтернет-індустрії, провайдерів доступу та змісту.

Для медіасфери, в якій відношення між журналістами та аудиторією демократизуються, останнє має величезне значення. Цим визнається, що вплив аудиторії на контент, який невпинно зростає, стимулює розвиток інформаційнокомунікаційних технологій. 3 іншого боку, колишня концепція свободи журналістської діяльності потребує корегування, бо в процесі цієї діяльності аудиторія вже не є мовчазною та пасивною спільнотою. Навпаки, користувачі, маючи величезний вибір медіаконтенту, переймають на себе одну 3 найважливіших функцій журналіста-формування інформаційної черги денної. Використовуючи новітні технології, вони все більше перетворюються у своєрідного співучасника процесу створення медіаконтенту. Це, з одного боку, посилює депрофесіоналізацію журналістів, а з іншого-знижує рівень інформаційної залежності аудиторії від медіа- професіоналів.

Ще більш значні зміни відбулись на рівні суспільства взагалі. В політиці в останню третину ХХ століття утвердилась концепція «кінця ідеології» та конвергенції двох ідеологічних систем, що протистояли одна одній в холодній війні, яку висунули 3. Бжезінський, Д. Белл та деякі інші теоретики. Альтернативою політичним організаціям та громадянським інститутам стали антивоєнні, 
правозахисні та екологічні рухи, «народна дипломатія» та наявні чи не в кожній розвинутій країні локальні угрупування, які обстоюють інтереси етнічних, культурних, сексуальних меншин, екзотичних релігійних організацій тощо.

Як справедливо зазначас Д. Іванов, відбувається «міноритизація (від. англ. minority - меншість) політики. Електорат як однорідна маса, що розподілялась на більшість і меншість вздовж єдиної осі «праві - ліві», змінюється конгломератом меншин, для яких головною ставкою в політичній боротьбі $є$ право на альтернативний спосіб життя. Мультикультуралізм стає не стільки ідейним, скільки прагматичним підгрунтям політичної діяльності» [6, 378].

Як наслідок, боротьба за політичну владу у нових умовах - це не боротьба ідеологій, програм дій чи партійних організацій. Нині - це боротьба образів, політичних іміджів, які створюють рейтинг кандидатів чи партії. Реальні особистості та діяльність політиків в умовах «символічної політики» необхідні всього лише як «інформаційний привід» для медіа, ПР-агенцій, іміджмейкерів. Заміна реальних політичних позицій і дій їх образами зберігає політику у вигляді симулякрів і забезпечує успіх тим кандидатам, чий імідж, а зовсім не програма та ідеологія, уособлюють цінності суспільства.

Диференціація деполітизованих управлінців та носіїв іміджу публічних політиків - сутність віртуалізації головних громадянських інститутів - власне держави та виборів. Інший симптом віртуалізації інститутів демократії - заміна апеляцій до громадянської думки маніпуляціями з рейтингами. Рейтинги, що базуються на вибіркових опитуваннях, давно перетворились на модель, образ громадської думки. Саме ці образи і стають реальними факторами прийняття та здійснення політичних рішень.

Ще одним суттєвим наслідком формування мережевого суспільства стає усунення держави $з$ тих сфер, де вона традиційно визначала «правила гри». Це особливо відчувається у сфері регулювання ЗМК. Як вказує англійський дослідник А. Маттеларт, «свобода комунікації більше не викликає жодних сумнівів. Будь-які заперечення на адресу подібної концепції сприйматимуться як відновлення цензури... Принцип саморегуляції використовується для того, щоб делегітимізувати будь-яку спробу формування національної чи регіональної політики у цій сфері» $[18,146]$.

Разом $з$ тим той оптимізм відносно переваг інформаційного суспільства над іншими стадіями людського розвитку, що був притаманний працям «батьківзасновників» нової суспільної формації, сьогодні змінився більш стриманим відношенням до бурхливого розвитку новітніх технологій і визначенням тих загроз, які з'являються у зв'язку з їх появою.

Німецький філософ та комунікативіст Ю. Габермас розробив концепцію розвитку вільної від будь-якої залежності комунікації. Вона включає в себе такі аспекти: рівність учасників комунікації та свободу від утисків; темою дебатів $\epsilon$ загальнозначущі проблеми, що важливі для всіх; заборону обмежень дискурсу та можливість його відновлення за вимогою учасників [12,102].

На перший погляд, саме новітні технології, зокрема, Інтернет забезпечують реалізацію усіх цих вимог. Адже саме тут відсутня цензура, всі голоси мають 
однакову вагу і значущість, кожен може у будь-який момент реального часу висловити свою думку. Однак ці окремі голоси так і не зливаються у єдиний хор громадської думки, а сама можливість співіснування мільйонів окремих голосів не забезпечує реалізацію мрії демократів про існування незалежної від спонукання та відмінностей громадськості («публіки», за термінологією Ю. Габермаса).

Як справедливо зазаначає Б. Марков, основною проблемою Інтернету $є$ не акумуляція, а селекція, бо ця комунікація не об'єднує, а лише сегментує і диференціює. І справа навіть не в тому, що під час такого спілкування втрачаються суттєві елементи відкритої комунікації «обличчям до обличчя» (наприклад, невербальна інформація). Чужа аргументація вимагає осмислення і перевірки, а на це бракує часу. Питання, відповіді, коментарі йдуть синхронно, єдиним потоком, не залишаючи можливості для формування власної думки. Крім того таку розмову можна без зайвих пояснень перервати у будь-який момент, уникаючи відповідальності за те, що було оприлюднене [див.: 9, 467-477].

Інтернет зовсім не ліквідує ієрархію, як це може здатись при першому 3 ним знайомстві. Але якщо придивитись уважніше, то виявиться, що інтерактивне використання мультимедійних можливостей реалізується далеко нерівноцінно. А це означає, що на практиці існують різні рівні інтерактивності. Перший рівень - це лише вибір програм, що тобі цікаві, другий - рудиментарне втручання i спроби знайти додаткову інформацію і лише третій - це робота 3 програмами у дигітальному вигляді і можливість активно втручатись у іï побудову. Тобто ведучими все одно залишуться ті, хто володіє мережею, розробляє програми чи просто має більш високий рівень підготовки або освіти.

I, нарешті, в умовах громадянського суспільства «публіка», про яку пише німецький фахівець, виступає як опозиція у вічному балансуванні між суспільством і державними інститутами. Вона породжує соціальні групи, які представляють різні інтереси, ініціюють обговорення тих чи інших проблем, проводять моніторинг дій влади. В Інтернеті в умовах «дігітальної анонімності», за висловом Б. Маркова, втрачаються соціальні, етнічні, вікові, культурні та інші відмінності. Громадськість розпадається на угрупування за інтересами, яке може виходити навіть за межі держави. Зрозуміло, що ця «демократія без берегів» вже не може слугувати інтересам суспільства у звичному його розумінні, замкнувшись на інтересах нових «віртуальних угрупувань».

Однією з таких ознак віртуалізації соціального та громадсько-політичного життя суспільства стало створення «електронних урядів». Сутність ідеї такого уряду полягала у вдосконаленні моделей надання послуг населенню та підвищення ефективності функціонування органів влади і державних установ. При цьому домінуючим принципом діяльності такого уряду повинна була стати його доступність кожному суб'єкту суспільства, у будь-який час і з будь-якого місця, де є мережа Інтернет [див.: 20,14].

Крім того сьогодні електронний уряд все частіше починають розглядати як реальний шлях подальшого розвитку демократичних принципів у суспільстві, що знайшло своє віддзеркалення навіть у появі термінів «електронна демокра- 
тія» або «кібердемократія». Цей шлях полягає у добровільному перерозподілі владних повноважень та деяких управлінських функцій на користь суспільства, яке представлене окремими громадянами, різними спільнотами, асоціаціями, приватним сектором, бізнесом, громадськими організаціями, що і складають поняття «суспільство» та громадськість. Цей шлях якраз і відкрило розповсюдження інформаційних технологій, у першу чергу Інтернету, які надали урядом та державним установам усіх рівнів широкі можливості для переходу до нових форм управління та новим принципам взаємодії зі своїми громадянами.

На початкових стадіях свого становлення електронний уряд обмежується, як правило, забезпеченням доступу громадян до суспільно-значущої інформації уряду, а також наданням можливості голосувати за ті чи інші його рішення. Наступна еволюція розширяе можливості обох сторін і може призвести до того, що у громадян з'явиться можливість самостійно вибирати будь-який рівень участі в електронній демократії.

Фахівці виділяють ці рівні взаємодії, що вже реалізовані у розвинутих країнах: доступ до інформації, яка знаходиться в уряді; онлайнове обговорення проблем з експертами та держслужбовцями; онлайнове обговорення суспільних проблем з іншими громадянами країни; онлайнова взаємодія з урядом у межах програми громадського доступу; формування власних пропозицій і міркувань щодо проблем, обговорення яких ініціює уряд; голосування 3 тих чи інших проблем [див.: 20, 15].

Однак ця здавалось би найширша участь громадян у вирішенні всього кола соціальних та політичних питань, що постають перед суспільством, зміщує акценти з базових компонентів політичної практики (ідеології, організації, громадської думки) на технологію, яка забезпечує реалізацію майже методології анархічного гасла «можна все».

На думку французького дослідника А. Турена, «соціальне» зникає в новітніх технологіях комунікації як у «чорних дірах», а суспільство на часі виглядає не як «інституціонально врегульоване ціле», а як арена «конфліктів, які виникають через розподіл символічних благ» $[20,23]$. Подібна ситуація допускає і провокує перетворення глобальної комп'ютерної мережі Інтернет в засіб - середовище громадянсько-політичної діяльності та боротьби.

\section{СПИСОК ДЖЕРЕЛ}

1. Бодрійяр Ж. Симулякри і симуляція / Пер.з франи. В. Ховхуна. - К.: Основи, 2004. $-278 \mathrm{c}$.

2. Вебер М. Избранное. Образ общества: Пер.с нем.- М.: Юрист, 1994. 704 с. - Серия «Лики культуры».

3. Землянова Л. М. Коммуникативистика и средства информации. Англорусский словарь конщепџий и терминов. - М.: Издательство МГУ, 2004. 416 c. - Серия «21 век. Информация и общество».

4. Иванов Д. В. Феномен компьютеризачии как сочиологическая проблема // Проблемы теоретической соииологии. - Bып. 3, 2000. - с. 29 - 43. 
5. Иванов Д. Общество как виртуальная реальность // Информачионное общество: Сб. - М.: ООО «Издательство АСТ», 2004. - с. 355 - 427. Серия: Philosophy.

6. Кастельс М. Информачионная эпоха: экономика, общество и культура / Пер.с англ., под. научн ред.. О. И. Шкаратана. - М.: ГУВШЭ, 2000. - 820 с.

7. Левада Ю. А. Общественное мнение у горизонта столетий // Экономические и сочиальные перемены. - М., 2000. - № 6- с. 36- 73.

8. Маклуэн М. С появлением Спутника планета стала глобальным театром...// Кентавр, 1994. - № 3. - с. 25 - 49.

9. Марков Б. Человек в эпоху масс-медиа // Информационное общество: Сб. M.: ООО «Издательство АСТ», 2004. - c.452 - 507. - Серия: Philosophy.

10.Рожков В. Ю. Интернет и сочиальные аспекты общества // Вестник Московского университета. Серия 10: Журналистика, 2008. - № 3. c. $68-76$.

11.Тоффлер Э. Шок будущего / Пер.с англ. О. А. Феофанова. - М.: Акмаnресc, 2004. $-662 \mathrm{c}$.

12.Хабермас Ю. Моральное сознание и коммуникативное действие / Пер.с нем.под ред. Д. В. Скляднева. - СПб.: Наука, 2001. - 379 с.

13.Хеншель Р. Определение соииальных проблем средствами массовой информации // Средства массовой коммуникачии и социальные проблемы / Под ред.. С. А. Ярмухамедова. - Казань: Издательство Казанского университета, 2000. - c. $61-94$.

14.Bell D. The end of ideology. - N.Y.: Basic Books, 1960. - 184 p.

15. Cuilenburg G.van. New perspective on media diversity. Toward a criticalrational approach to media performance / Changing media and communications: concept, technologies and ethic in global and national perspectives / Ed. by Y. N. Zassoursky, E. Vartanova. - M.: Progress, 1998. - p. $72-91$.

16. Machlup F. The Production of Distribution of Knowledge in the United States. - N.Y. Princeton, 1962. -186 p.

17.Masuda Y. The Information Society as Postindustrial Society. - Walsh: World Future Soc., 1983. -248 p.

18. Mattelart A. Multinational Corporations and the Control of Culture: The Ideological Apparatuses of Imperialism. - Brighton: Harvester, 1979. - 183p.

19.Robertson D.S. Globalization: Social Theory and Global Culture. - N.Y.: Sage, 1992. $-268 \mathrm{p}$.

20.Touraine A. The waning sociological image of social life // International journal of comparative sociology. - P., 1984. - № 1. - P. $14-33 c$. 


\section{3. ЛИТЕРАТУРА И КУЛЬТУРНО-СМЫСЛОВЫЕ ПРОБЛЕМЫ ТЕОРИИ ПОСТМОДЕРНИЗМА}

Важнейшая задача, которую ставят перед собой гуманитарные науки, заключается, как известно, в том, чтобы «выявить неявное», не просто описать результаты культурной деятельности человека в их непосредственной данности, но вскрыть зачастую неосознаваемые механизмы этой деятельности, глубинные пружины культуры, приводящие ее в движение.

«Текучая современность» (по выражению 3. Баумана), уживающаяся тем не менее с жесткостью категорий, предлагает целый комплекс научных проблем, связанных и с возникновением новых предметных и проблемных областей, и со становлением ряда новых направлений. Это теории коммуникаций, гендерные исследования, институциональные политические исследования, постмодерная литературная критика, социальная антропология и т.д. В этих новых для украинской (и в известной степени) мировой науки областях знания своего рода парадоксом является как междисциплинарность исследований, так и их субдисциплинарная дифференциация. Отсюда - одна из нерешенных научных задач теоретическое осмысление соотношения междисциплинарности и частнонаучности в современных исследованиях.

Необходимость междисциплинарного подхода сегодня, как правило, не подвергается сомнению в научном мире, но явно недостаточно попыток проанализировать целый ряд проблем, возникающих из-за различных толкований одних и тех же понятий в разных дисциплинах, рассмотреть применение и содержание методов исследования в зависимости от специфики конкретной научной области.

Возобновление интереса в конце XX в. к содержательной стороне интерпретации текста, к культурно-смысловым проблемам литературы, к социальному контексту восприятия литературного произведения не вызывает сомнения. Отвечая на вопрос, почему литература оказалась на периферии современного общества, Вольфганг Изер, один из создателей школы рецептивной эстетики, пишет, что, очевидно, литература утратила некоторые функции, ранее свойственные ей в такой степени, что они и принимались собственно за литературу. Размышляя об антропологических функциях литературы, В. Изер утверждает, что отождествление литературы с её практическим использованием устарело: «литературе не удалось привести человека на вершину его возможностей, ... литература не есть ни бегство от действительности, ни подмена действительности. Она реагирует, откликается на действительность, и при этом интерпретирует её». И поскольку литература является формой интерпретации, она должна быть связана с действительным миром, - утверждает постструктуралист В. Изер [1, с. 37-38].

Как и для всех постструктуралистов, литература для М. Фуко - часть широкого социально-культурного контекста, и он выступает за усложнение интерпретации текста, утверждая важность интертекстуальности. М. Фуко делает акцент на политических последствиях факта создания произведения, на 
политическом бессознательном, отсюда - проблематизация таких концепций, как «автор» и «произведение». Автор, по Фуко, это «идеологический конструкт», предназначенный для борьбы с «расползанием значений». М. Фуко считает, что творчество автора как единство образовано некой операцией, и эта операция носит интерпретативный характер. Следовательно, продолжает философ, «творчество автора не может рассматриваться ни как непосредственно данное, ни как достоверное, ни как однородное единство [2, с. 68]».

Хотелось бы подчеркнуть тот факт, что в любом литературном произведении, кроме множества неявных смыслов, есть еще и явные значения, хотя они и представляются постструктуралистам явно сомнительными. Именно на «явных» смыслах делают акцент сторонники социологического метода анализа художественного произведения, крупными представителями которого в Европе во второй половине XX в. были Т. В. Адорно и Л. Гольдман. Полемизируя с психоаналитической теорией искусства, с Кантом и Фрейдом, Адорно различает искусство «подлинное» (для Адорно это авангардизм и модернизм XX века) и «идеологическое», призванное обеспечить действующей культуре возможность манипулировать массовым сознанием [3].

Люсьен Гольдман, создатель франко-бельгийской школы «генетического структурализма», попыткой построить литературоведение не как гуманитарную, а именно как социально-гуманитарную науку проложил, по утверждению Г. Косикова, новые для западного искусствознания пути, хотя и повторил во многом методологический ход мысли, характерный для таких теоретиков конца XIX - начала XX века, как П. Лафарг, Г. В. Плеханов и В. Ф. Переверзев. Логика ошибки Гольдмана, как полагает Г. Косиков, «в одностороннем истолковании тезиса, согласно которому «бытие определяет сознание». Гольдман понимает это бытие как материальные условия и социальный образ жизни класса, которые как бы автоматически определяют и его сознание; сознание оказывается простым рефлексом, пассивным продуктом социально-экономической секреции $[4$, c. 32]». Тем не менее Гольдмана часто причисляют к французской «новой критике», получившей широкое развитие во второй половине XX в. и оказавшей, как известно, большое влияние на критическую мысль Европы и США.

Бесспорно, литература как уникальный источник знаний о личности и обществе является привилегированным материалом в исследованиях современных философов. Во второй половине XX века получает официальное признание понятие философии литературы, существующие в трех основных вариантах: «вопервых, включение литературы как равноправного компонента в контекст философии того или иного мыслителя, во-вторых, сопоставление философии и литературы как двух автономных практик с целью обнаружить их сходство и различие, в-третьих, попытки найти философские проблемы собственно в литературных текстах [5, с. 763]».

С другой стороны, литературно-критическая теория и по форме, и по содержанию уже на этапе возникновения в 1960-1980-х годах отчетливо сопротивляется рубрикации и классификации. Как правило, теоретические работы исследователей в области литературной теории (Literary Theory) дискурсивны, т.е. их значение 
выходит за рамки литературной критики, они могут быть использованы в других дисциплинах, влияя на них, вызывая их переосмысление. Как отмечается, для такой «переводимости» с языка одной дисциплины на другой тексты теоретиков не могут носить сугубо специального характера, они должны быть понятны «соседям». Философы, со своей стороны, стремятся исследовать литературные тексты, отражающие определенные философские воззрения, обогащая философский дискурс романными произведениями, драматургией и поэзией.

Один из крупнейших современных философов Ж. Деррида определяет литературу как «исторически обусловленную институцию со своими конвенциями, правилами и т.д., но это также институция вымысла, которая в принципе позволяет сказать все, что угодно, нарушить, обойти любые правила, и тем самым установить, изобрести границы - и одновременно подвергнуть их сомнению - между природой и институцией, природой и законом, природой и историей [6, с. 37]». Ж. Деррида утверждает далее: «Вполне возможно, что современная литература - нечто большее, чем один из многих способов письма, что это своего рода путеводная нить, дающая доступ в общие законы текста. То, что происходит с языком в литературе, обнажает не только ей, литературе, присущую власть, власть, которую она до определенной степени делит, например, с языком юриспруденции; в нашей исторической ситуации литература дает нам нечто большее - знание «сути» письма вообще, учит нас философскому и научному (например, лингвистическому) постижению границ письма [6, с. 71-72]». Уникальность современной литературы Вольфганг Изер видит в том, что «литература перестала быть институтом, направленным на созерцание ауры, исходящей от классических шедевров. Она больше не воображаемый музей [1, с. 38]».

Междисциплинарность современного гуманитарного знания также является аксиомой для западной критической теории (Critical Theory). Плюралистичность, направленность против привычных схем мышления литературной теории роднит её с критической теорией, или просто «теорией». Приверженцы плюралистического взгляда на художественные произведения исходят из убеждения, что в основе литературной критики лежит ряд самостоятельных методов, игнорирование которых (или предпочтение одного другим) лишает критика перспективы в изучении художественной литературы.

Общеизвестно, что великие постмодернисты Барт, Деррида, Кристева и многие другие являются, прежде всего, литературными критиками, т.е. ученые, работающие в сфере литературной теории, используют художественные тексты не только для интерпретации самих этих текстов, но и для постановки на их материале философских, антропологических, социальных проблем. С другой стороны, имена крупных философов не означают, что сегодняшнее развитие литературной теории - побочный продукт философии. Как правило, пишет Пол де Ман, «современная литературная теория представляет собой относительно автономную постановку вопросов, которые ставит в своем контексте и философия, не обязательно более четкую и строгую, чем в философии [7, с. 117]». Литературная теория сегодня вызывает законный интерес философии, - считает признанный глава американского деконструктивизма. 
Неомарксист Ф. Д. Джеймсон пишет: «Ещё один показатель идущего у нас на глазах размывания старых категорий можно найти в сфере так называемой современной теории. В прошлом поколении ещё существовал самостоятельный язык философии - великие системы Сартра и феноменологии, работы Витгенштейна, философия языка, а наряду с ним вполне поддавались разграничению профессиональные языки прочих академических дисциплин, например, политологии, социологии, литературной критики. Сегодня мы все больше имеем дело просто с «теорией», которая одновременно включает в себя все эти дисциплины и не является ни одной из них. Например, труды Мишеля Фуко - это философия, история, общественная теория или политология? Вопрос неразрешимый, и, я полагаю, что такой «теоретический дискурс» тоже следует считать проявлением постмодернизма [8, с. 275]».

В свою очередь М. Фуко также задает вопрос: «Что такое отдельная наука? Что такое творчество отдельного автора? Что такое отдельная теория? Отдельное понятие? Отдельный текст? [2, с. 40]».

Как известно, марксистский метод в литературоведческом исследовании отвергает такое изучение искусства, при котором оно рассматривается как нечто обособленное и замкнутое в себе. Напротив, он доказывает, что художественная литература является одной из форм общественного сознания, развитие которого определяется развитием общественного бытия людей, следовательно, удельный вес общественно-классового критерия в оценке произведений художественной литературы должен быть большим. Неомарксисты задачу социологии литературы видят специфичнее и шире: «Она состоит в том, чтобы путем количественного и качественного анализов, опираясь на традиции и новейшие достижения исторической, социологической и других гуманитарных наук, стремиться ко все более полному изучению общественных и общечеловеческих проблем. Социология литературы исследует контакты индивида с окружающей его общественной средой, анализирует социальные связи между индивидами и рассматривает особенности их духовного развития [9, с. 291]».

«Социальный текст» как ключевое понятие в работах американских левых деконструктивистов существенно раздвигает границы интертекстуальности. Его сторонники (Дж. Бренкман, М. Риан, Ф. Джеймсон) рассматривают литературный текст в контексте общекультурного дискурса, включая религиозные, политические и экономические дискурсы. Взятые все вместе, они и образуют общий, или Социальный текст. Тем самым левые деконструктивисты напрямую связывают художественные произведения не только с соответствующей им литературной традицией, но и с историей культуры.

Ф. Джеймсон, американский критик-неомарксист, в литературном произведении выводит на поверхность его «политическое бессознательное», отразившийся в нем социальный опыт, применяя для этого методы герменевтики. Для Терри Иглтона, ведущего английского критика-марксиста, литература не сводится к идеологической форме той или иной формации, его главный интерес лежит не в сфере собственно анализа текста произведения, а на уровне обобщений о культуре и идеологии, породивших конкретное произведение. 
Иглтон признает сложность такого феномена человеческого сознания, как идеология, утверждая, что она никогда не является простым отражением идей господствующего класса. Напротив, она всегда представляет собой сложный феномен, который может включать в себя конфликтующие, даже противоположные взгляды на мир. Чтобы понять «Короля Лира», «Дунсиаду» или «Улисса», - пишет он, - нужно нечто большее, чем умение просто интерпретировать их символику. Прежде всего необходимо понять сложные, непрямые отношения между этими произведениями и идеологическими мирами, в которых они обитают, отношения, которые не просто проявляются в «темах» и «пристрастияХ» писателя, но живут в стиле, ритме, образах, качестве и форме [10].

Маловероятно, что критика придет к равновесию, признающему одинаковую ценность и вымысла, и факта в художественном произведении, или даст однозначный ответ на вопрос об отношении автора к созданному им произведению. Поэтика постмодернизма, оказавшая глубокое воздействие на общеметодологические принципы литературоведения, породила больше вопросов, чем приемлемых для всех ответов. И хотя в эпоху постмодерна язык социального анализа всё чаще заменяется языком антропологии, рассмотрение литературы в контексте социальной действительности по-прежнему представляется актуальным и перспективным.

\section{СПИСОК ИСТОЧНИКОВ}

1. Изер В. Изменения функций литературы // Современная литературная теория.

2. Антология. - М.: Флинта, Наука, 2004.

3. Фуко М. Археология знания. - СПб: «Гуманитарная академия», Университетская книга, 2004.

4. Адорно Т. В. Эстетическая теория. - М., 2001. - 527c.

5. Косиков Т. В. Зарубежное литературоведение и теоретические проблемы науки о литературе // Зарубежная эстетика и теория литературы ХІХ-ХХ веков. Трактаты, статьи, эссе. - М.: Издательство МГУ, 1987.

6. Современный философский словарь. Под общей ред. В. Кемерова. М.: Академический Проект, 2004.

7. Derrida J. Acts of literature. - New York, London: Routledge, 1992.

8. Ман де П. Сопротивление теории // Современная литературная теория. - М.: Флинта, Наука, 2004.

9. Джеймсон Ф. Постмодернизм, или культурная логика позднего капитализма // Современная литературная теория. - М.: Флинта, Наука, 2004.

10.Гуревич П. С. Новые тенденции сочиологии литературы // Зарубежное литературоведение 70-х годов. Направления, тенденции, проблемы. - М.: Наука, 1984.

11.Eagleton T. Five types of identity and difference // Multicultural States. London and New York: Routledge, 1998. - P. 48-52. 


\section{4. УНІВЕРСИТЕТСЬКА БІБЛІОТЕКА НА СУЧАСНОМУ ЕТАПІ РОЗВИТКУ СОЦІАЛЬНИХ КОМУНІКАЦІЙ}

Соціальні комунікації представляють собою, за визначенням В. Ільганаєвої, сукупність процесів та структур, які забезпечують цілеспрямований обмін соціально значущою інформацією та знаннями в просторово-часовому контініумі $[3$, c. 310]. Такий обмін відбувається завдяки існуванню комунікаційних каналів, аналіз еволюції яких, починаючи від стадії пракультури і закінчуючи сучасною електронною комунікацією, дозволяє говорити про їх спадкоємність. При цьому, слід враховувати, що послідовна зміна суспільних комунікаційних систем відбувається не стихійно, а в силу кризи комунікаційних каналів, які $\epsilon$ засобами передачі повідомлень від джерела до отримувача або шляхом фізичної передачі повідомлень. Ця криза, в свою чергу, полягає в тому, що ці канали перестають задовольняти комунікаційні потреби як окремих людей, так і суспільства в цілому. Вирішення кризи досягається шляхом біфуркації (розділення) перевантажених комунікаційних каналів. За думкою професора А. В. Соколова [12], аналізуючи таким чином еволюцію комунікаційних каналів, починаючи від стадії пракультури і закінчуючи сьогоденною електронною комунікацією, можна виділити 4 біфуркації:

- Біфуркація I - поява писемності та літературної мови ( 3 III тис. до н. е XV ст. н.е.);

- Біфуркація II - винахід книгодрукування та великі географічні відкриття (XV - 1а пол. ХІХ ст.);

- Біфуркація III - промисловий переворот, який обумовив появу первинних технічних каналів, в тому числі машинної поліграфії, фотографії, телефону (2-а пол. XIX - 2-а пол. XX);

- Біфуркація IV - науково-технічна революція XX ст., яка викликала до життя електронну комунікацію - телебачення та комп’ютер.

При цьому слід зазначити, що еволюція соціальних комунікацій органічно пов'язана з еволюцією культури, яка визначається пануючими у суспільстві нормами і засобами фіксації, збереження та розповсюдження культурних змістів. Напрямки цих комунікацій можна представити наступним чином:

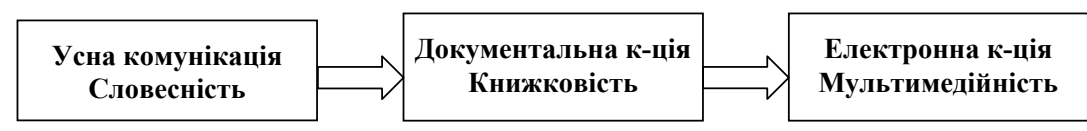

Таким чином, можемо визначити сучасну епоху як перехідний період від ери документальної комунікації і книжкової культури до ери електронної комунікації і мультимедійної культури. Перехід суспільства до цієї епохи заснований на об'єднанні двох, існуючих протягом всього розвитку цивілізації, паралельних процесів. Суть першого полягає в постійному зростанні необхідної для забезпечення життєдіяльності суспільства значущості інформації та збільшенні 
iii обсягів. Другий процес грунтується на удосконаленні технологій накопичення, обробки та розповсюдження інформації. Осмислюючи майбутню еволюцію соціуму, видатний японський учений Е. Масуда розробив і представив у книзі «Інформаційне суспільство як постіндустріальне суспільство» одну з найбільш цікавих концепцій інформаційного суспільства. В ній філософ результатом об'єднання двох вищезгаданих процесів вбачає те, що «виробництво інформаційного продукту, а не продукту матеріального перетворилось на рушійну силу формування і розвитку суспільства» [22, с. 64].

Відмінною рисою сучасності є інформатизація всіх сторін життя, поступове розуміння пріоритетності інтелектуальних сфер діяльності, перетворення інформації в стратегічний ресурс суспільства.

Реалії сьогодення підтверджують факт того, що основою глобальних змін у сучасному суспільстві $є$ утворення його єдиного інформаційного простору на базі інформаційно-комунікаційних технологій (ІКТ). Сформувалась глобальна система соціальних комунікацій (бібліотеки, архіви, музеї, центри інформації, ЗМI, кіно-фотоіндустрія, театри, книгарні, служби НТI, аналітичні центри тощо), яка сприйняла всі інновації ІКТ та основи функціонування реального і віртуального інформаційного простору. При цьому, особливих змін набули звичні носії інформації - книжково-документальні. Зараз світова спільнота швидко опановує електронні засоби навчання та електронні ресурси освіти і науки, реалізуючи при цьому основну концепцію інформаційного суспільства доступність будь-якої інформації кожному члену суспільства в будь-якому місті і в будь-який час.

Таким чином, в умовах переходу до ери інформаційних комунікацій місія бібліотек, яка в епоху документальних комунікацій полягала в збереженні і передачі в часі документальної інформації, змінилася на забезпечення до неї доступу.

Чи готова національна освіта та бібліотеки ВНЗ, діяльність яких переміщується в нове комунікаційне середовище, до виконання своєї місії в такому суспільстві?

Болонський процес офіційно завершується цього року. I саме тоді Україна та інші країни, які підписали Болонську декларацію, повинні підвести риску під процесами реформування власних систем вищої освіти і проголосити про утворення гармонізованого Єдиного європейського освітнього і наукового простору. Така тенденція до глобалізації передбачає створення великих корпоративних систем шляхом інтеграції раніш ізольованих організацій в єдине ціле, зокрема об'єднання бібліотечно-інформаційних структур в єдиний національний та європейський простір. Головною рушійною силою даних процесів виступає інформатизація бібліотек вищих навчальних закладів.

Бібліотека університету, яка, надаючи інформаційну підтримку навчальній, науковій та виховній діяльності, традиційно $€$ центром комунікацій різноманітної університетської спільноти, займає одне з провідних місць в інформаційноосвітньому середовищі навчального закладу. Активне зростання затребуваності бібліотеки як інформаційного посередника між користувачем та безмежними масивами інформації обумовлено багатьма факторами, серед яких можна особливо виділити наступні: 
- інформатизація ВНЗ та бібліотеки як компоненту його інформаційноосвітнього середовища, метою якого $є$ забезпечення інформаційних потреб суб'єктів освітнього процесу шляхом забезпечення доступу до інформаційних ресурсів;

- розвиток інтеграційних процесів національної освіти у європейське i світове освітне товариство;

- переосмислення ролі самостійної роботи студентів в процесі навчання;

- запобігання інформаційній ізольованості учених та прискорення їх інтеграції до світової наукової спільноти;

- впровадження дистанційних форм навчання;

- створення якісно нового освітнього середовища.

Узагальнюючи досвід новаторських книгозбірень щодо їх трансформації в інтегровані інформаційні науково-освітні, дослідницькі, культурологічні центри, які мають широкі спектри інформаційних послуг та функцій досвідчених навігаторів інформаційних потоків, а також беручи до уваги праці вченихфундаторів бібліотечно-інформаційної справи, ми можемо визначити основні напрямки інформатизації бібліотек ВНЗ в умовах реформування вищої освіти. Ними є:

1. Створення умов для засвоєння необхідного рівня автоматизації діяльності і входження до відповідних інформаційних мереж;

2. Забезпечення безперешкодного доступу до інформації користувачам;

3. Створення відповідної системи доступу, представлення і використання інформації в галузі освіти;

4. Забезпечення представництва генеруємої інформації в інформаційних мережах [6, с. 171].

В умовах жорсткої конкуренції на ринку освітніх послуг конкурентноздатність ВНЗ тим вище, чим високотехнологічнішим та якіснішим є його інформаційно-освітнє середовище. А одним із основних показників якості освіти $є$ затребуваність випускників при працевлаштуванні, конкурентноздатність їх знань і компетенцій на ринку праці.

Які ж саме компетенції повинен мати молодий спеціаліст сучасного ВНЗ в епоху активного формування інформаційного суспільства та суспільства знань?

Це: • здібність до навчання; • здібність до пошуку інформації; • здібність аналізувати інформацію та виділяти ключові позиції; • здібність до генерування нових знань; • наявність глибоких знань предметної галузі; • здібність до прийняття рішень та відповідальності за це; • володіння інформаційнокомунікаційними технологіями.

На думку автора, з семи компетенцій - чотири базуються на безпосередній спроможності бібліотек вишів активно включитися, а, можливо, інколи і очолити процеси з їх формування. Наприклад, це стосується організації процесу навчання 3 метою формування інформаційної культури студентів. В умовах переходу до когнітивно насичених соціальних комунікацій, коли пріоритетним стає знання про інформацію, необхідним $є$ набуття навичок орієнтації в інформаційних ресурсах, їх оцінки та аналізу, організації доступу до них тощо. Оскільки 
змістом місії бібліотек у комунікаційному просторі сучасності є формування нових якостей свідомості на суспільному, колективному та індивідуальному рівнях [4, с. 12], то держава саме на бібліотеки поклала завдання $з$ навчання користувачів основним правилам пошуку і збору інформації, методам аналізу складу і структури документального потоку, реферуванню літератури, способам організації особистих картотек і досьє.

Інформатизація освіти неминуче вимагає інтенсивного зростання потреб вищої школи в електронних інформаційних ресурсах, тому колекції електронних ресурсів стають обов'язковою та звичною складовою сучасної бібліотеки ВНЗ. А найближчим часом динаміка їх розвитку на основі застосування інформаційно-комп'ютерних технологій значно прискориться і навіть буде мати дещо експансивний характер. Це потребує від бібліотек розвитку власних стратегій щодо формування фондів, організації обслуговування користувачів, виробництва власних інформаційних продуктів, відпрацювання методик та технологій організації та управління е-ресурсами тощо. Все частіше актуальним для бібліотек, як захисників прав користувачів інформації, стає і пошук варіантів компромісу з правовласниками інформаційних об'єктів в умовах діючого законодавства $з$ авторського права. Яким же чином відбувається наповнення бібліотеки вишу електронними ресурсами?

\section{ЕЛЕКТРОННІ РЕСУРСИ БІБЛІОТЕКИ ВНЗ}

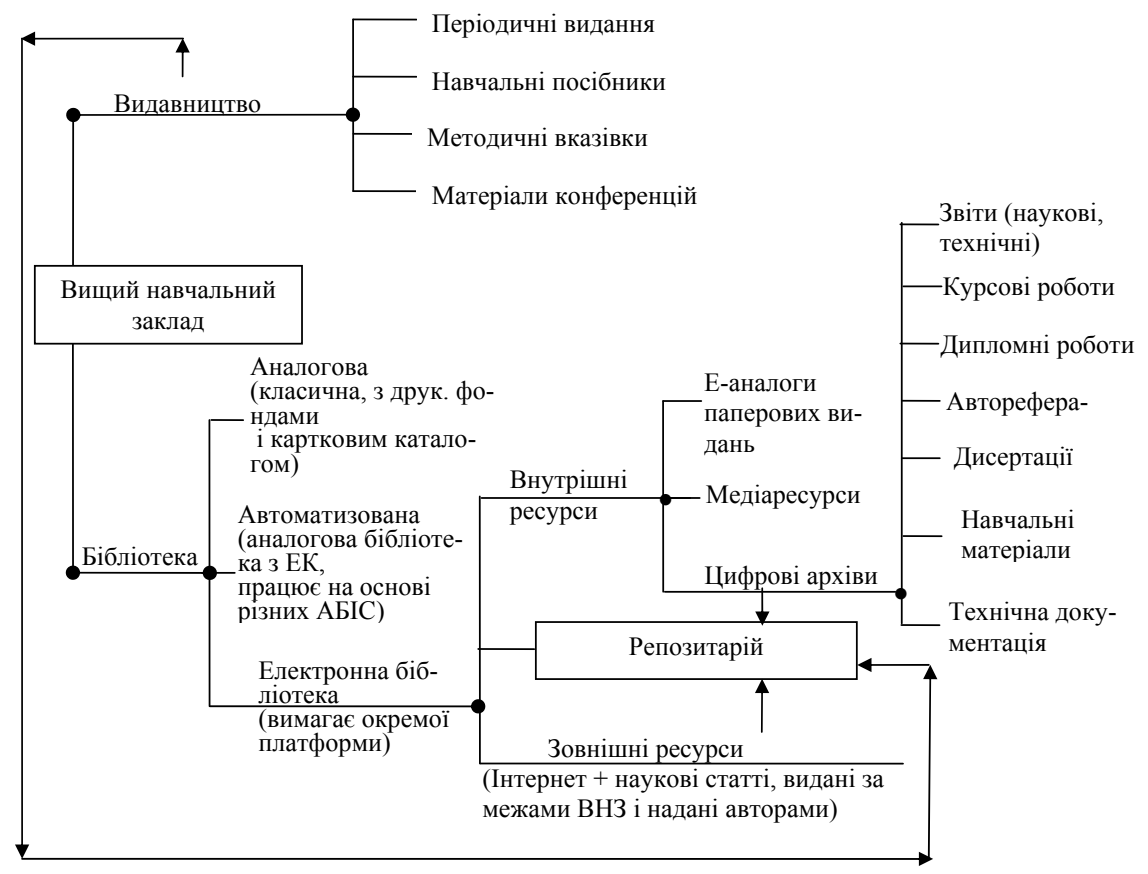


Надана схема дозволяє отримати уявлення щодо еволюційних трансформацій університетських бібліотек в умовах глобальної інформатизації та переходу до європейської моделі освіти. Це пов'язано з їх залученням одночасно до двох сфер духовного виробництва - бібліотечної і освітньої. Трансформація бібліотек вишів, яка полягає в зміні основних складових їх діяльності, до яких традиційно відносять: фонди, каталоги, бібліотечно-бібліографічне та інформаційне обслуговування, методичну роботу, матеріально-технічна базу, кадри, управління, перетворює книгозбірні в нові організаційно-функціональні елементи вищих закладів освіти, створюючи різні моделі бібліотек. Їх спільною особливістю $є$ наявність ознак бібліотеки як інформаційного центру.

Висвітлення питань формування нових моделей розвитку і вдосконалення книгозбірні, які за головну мету мають передбачення активної участі бібліотеки в підвищенні якості освітнього і науково-дослідного процесів у ВНЗ на основі удосконалення системи їх інформаційної підтримки і розширення власних інформаційно-інтелектуальних активів, потребує звернення до праць теоретиків та практиків бібліотечно-інформаційної справи. Наукові та практичні наробки Н. Апшай, О. Бобрової, П. Брофі, В. Ільганаєвої, І. Давидової, В. Дригайла, Л. Костенка, I. Павлуши, А. Племнека, М. Слободяника, Д. Солов'яненка, Г. Шемаєвої, Т. Ярошенко та ін. допомагають дослідити розвиток процесів моделювання в умовах відсутності в Україні модельного стандарту бібліотеки вищого навчального закладу. На відміну від України, в Росії йдуть активні процеси з розробки «Модельного стандарта библиотеки высшего образовательного учреждения XXI века» (рос.) [10], інших проектів основних нормативних показників діяльності сучасної бібліотеки ВНЗ з урахуванням її інформатизації і активного використання електронних ресурсів. Підготовлений до прийняття проект модельного стандарту діяльності бібліотеки галузевого науководослідницького закладу [11], в основу якого закладені положення «Модельного стандарта деятельности публичной библиотеки» Российской библиотечной ассоциации, принятого на ХІІ Ежегодной сессии РБА (22 мая 2008 года) (рос.).

До теоретичних аспектів розкриття теми дослідження належить визначення слова «модель», яке в загальному вигляді розглядається як зразок, що відтворює, імітує будову і дію якого-небудь об'єкту та використовується для одержання нових знань про цей об'єкт [2]. Відповідно до бібліотеки ВНЗ повна модель їі як системи є комбінацією кількох приватних моделей, що відображають відібрані підсистеми. Ї̈̈ створення передбачає вирішення кількох якісно нових складових. Ними $€$, наприклад, розробка наступних моделей бібліотек: організаційної (структурно-функціональної), технологічної, ресурсної, фінансовоекономічної.

Відомо, що за рівнем інформатизації виділяють три типи бібліотек аналогова (класична бібліотека с картковим каталогом), автоматизована (аналогова бібліотека, яка має електронний каталог) і електронна (автоматизована бібліотека, в якій значна частина інформації перебуває в електронному форматі). Будівництво технологічних моделей цих бібліотек, функціонуючих на базі традиційних, автоматизованих або інформаційно-комунікаційних технологій (IКТ), 
мають схожий набір підсистем. Вони відрізняються змістом окремих компонентів (номенклатурою обладнання, кадровим складом, асортиментом продуктів та послуг тощо). Наприклад, інформаційні ресурси традиційних технологій представлені друкованими матеріалами, в автоматизованих технологіях представлені друковані та електронні матеріали і електронний каталог, на базі ІКТ представлені тільки електронні ресурси.

В Україні не існує модельного стандарту бібліотеки вищого навчального закладу, але сьогодні категорія «бібліотека ВНЗ» позиціонується як інтегрований інтелектуальний простір, заповнений різноманітними інформаційними ресурсами та засобами інформаційної взаємодії. Тому $є$ всі підстави розглядати ії як головний системоутворюючий елемент, де генерується інформаційно-освітнє та соціокультурне середовище закладів освіти.

Враховуючи специфіку об'єкту дослідження, який має соціальну сутність, доцільним буде використання методу моделювання, а саме: концептуальної, вербальної та графічної моделей. Про необхідність створення нових моделей університетських бібліотек, здатних надати максимально сфокусовану інформаційну послугу студенту, викладачу i науковцю, та розробку нових інформаційних стратегій з оптимальним використанням нових IT-технологій, існує багато наукових наробок, представлених як вітчизняними фахівцями, так $\mathrm{i}$ закордонними теоретиками та практиками бібліотечно-інформаційної справи. Всі сучасні бібліотеки вишів декларують зміщення акценту з «володіння» IP на «доступ» до них та появу нової моделі бібліотеки, яка надає інформацію «коли потрібно» користувачу (Just-in-Time Library Model - JIT ) на противагу раніш декларованої концепції бібліотеки щодо придбання документів в фонд «про всяк випадок» (Just-in-Case Library Model - JCIT). Модель JIT, за думкою американського ученого С. Сунга (бібліотека Університету Ратгерса), спирається на доступ до мережевих інформаційних ресурсів, розподілених у просторі, але наданих користувачу в одному місці як щось цілісне [25]. Т. Ярошенко, підкреслюючи, що ідеальної моделі бібліотеки сучасного університету не існує, пропонує розглянути три варіанти існування сучасної бібліотеки вищого навчального закладу з точки зору їх загального образу [17]. Нам здається, що доречно буде ці моделі назвати як: «бібліотека-мінімаліст», «бібліотека як паралельний світ» та «бібліотека-максималіст». Але бібліотека - динамічна структура, яка розвивається, змінює свої функції. Дослідниця підкреслює, що «якою їй бути сьогодні і в майбутньому - залежить від того, яким буде університет. Але і навпаки - університет буде таким, яким буде його бібліотека» [17, с. 37].

Зважаючи на контент-аналіз праць іноземних і вітчизняних фахівців, власний практичний досвід, наважимося запропонувати власне бачення сучасних моделей бібліотек вишів світу, які сформувалися у відповідностями з особливостями діяльності ВНЗ і мають якийсь пріоритетний аспект розвитку, підкреслений авторами у творах.

Обгрунтування створення однієї з нових моделей функціонування та розвитку бібліотеки ВНЗ - «Бібліотека - інформаційний інтелект-центр», наведемо на прикладі книгозбірень Дніпропетровської області. 
Теоретичним підгрунтям розкриття теми виступає визначення слова «інтелект», яке трактується як розум, здатність людини думати, мислити, а також рівень іï розумового розвитку [2]. Бібліотека ВНЗ, надаючи користувачеві інформаційні послуги високої якості, забезпечуючи оперативне обслуговування i релевантність інформації, надаючи всі сучасні види сервісу (друковані копії, CD, DVD, web-доступ, доступ до баз даних тощо), навчаючи користувача формулювати інформаційні запити, знаходити, оцінювати та використовувати набуту інформацію, організуючи творчі заходи 3 метою натхнення читачів/користувачів на вивчення, дослідження та відкриття, дозволяє розширити межі інтелектуального розвитку студента, викладача і науковця.

Особливістю Дніпропетровського регіону є його визнання як центру космічної галузі, металургійної, хімічної, гірничо-переробної промисловості, машинобудування, розвинутого агропромислового комплексу та потужного транспортного вузла України. Тому важливим завданням сьогодення $є$ формування інтелектуальної еліти, здатної очолити, розвивати, вдосконалювати виробничі, наукові, освітні, культурні процеси регіону та країни. На території області функціонують 83 вищі навчальні заклади, в яких навчаються понад 188000 студентів. 3 них - 25 університетів, академій і інститутів III-IV рівнів акредитації, що надають освіту більше 161800 студентів. Навчання в них проводять понад 11000 викладачів. Наукові кадри (11844 осіб) у 88 наукових установах протягом 2008 року виконали наукових та науково-практичних робіт на суму 790,1 млн. гривень. 35051 фахівців, що мають науковий ступінь: доктори наук - 848 осіб, кандидати наук - 5051. Кількість установ, що мають: аспірантуру -28 , навчається аспірантів - 1669 осіб; докторантуру - 11, навчається докторантів - 59 [14].

Сучасний період характеризується становленням нової парадигми вищої освіти, яка базується на особистісно-орієнтованому підході. Це спонукає ВНЗ спрямовувати зусилля у визначенні, підтримці і розвитку позитивних якостей студентів, педагогів і науковців і формуванні на цій основі механізму самореалізації особистості. Вищі навчальні заклади Дніпропетровщини III-IV рівнів акредитації завдяки інформатизації впевнено крокують в напрямку створення електронних університетів, забезпечуючи синергію спільного розвитку всіх вузівських структур, взаємодія, взаємодоповнення і взаєморозуміння яких створюють нову якість освіти і науки в регіоні.

Інформаційною основою науково-освітньої і виховної діяльності, творчою лабораторією, від ресурсів і послуг якої в значному ступені залежить якість i зміст навчання, наукових досліджень, розкриття творчої особистості виступають бібліотеки вищих навчальних закладів Дніпропетровщини. Максимально доступні (технічно і комунікаційно), бібліотеки ВНЗ представляють з себе конгломерат систем бібліотечно-інформаційного обслуговування користувачів і мережевих технологій, завдяки яким істотно розширюється спектр продукції $\mathrm{i}$ послуг, наданих користувачам, та 3'являється можливість максимальної персоніфікації в задоволенні їх інформаційних потреб. Бібліотеки одними з перших серед структурних підрозділів вишів зазнають еволюційних трансформацій у 
напрямі змін технологічного, структурного, організаційного та функціонального устрою, i, забезпечуючи інформаційну підтримку у формуванні інтелектуальної еліти суспільства та залишаючись центрами духовного і інтелектуального спілкування і культури, формують нову модель функціонування та розвитку «Бібліотека - інформаційний інтелект-центр» (БІІ) [6].

Прикладом такої діяльності є науково-технічна бібліотека Дніпропетровського національного університету залізничного транспорту імені академіка В. Лазаряна, пріоритетність розвитку якої була підтверджена окремим пунктом Програми комп’ютеризації та інформатизації ДНУЗТ на 2007-2011 рр. під назвою «Розвиток бібліотеки як інформаційного інтелект-центру університету» i передбачає створення на їі базі єдиного інформаційного простору: книг, періодичних та продовжуваних видань, креслень, звітів про ндр, медіаресурсів, зустрічей, спілкування, комп'ютерних технології тощо.

Концепція розвитку схожа з концепцією моделі «Бібліотека - інформаційний інтелект-центр» притаманна університетським бібліотекам Міннесоти (США), які розглядаються як стратегічний актив вищого закладу освіти, що забезпечує інтелектуальне лідерство та екстраординарні інформаційні досліди в напрямку поширення знань. Їх місія - натхнення читачів/користувачів на вивчення, дослідження та відкриття через надання інформаційних ресурсів і послуг, співпрацю, експертизу [26].

Таким чином, можна стверджувати, що БІІЦ $є$ новою моделлю бібліотеки i, як наслідок цього, новим організаційно-функціональним елементом ВН3, завданням якого стає керування процесами функціонування інформаційного середовища закладу освіти через координацію документообігу і документозбереження, створення електронного інформаційного ресурсу, організацію доступу до нього, формування умов інформаційного споживання, розвитку творчих здібностей і інформаційної культури користувачів з метою забезпечення інтелектуального лідерства та екстраординарних інформаційних досліджень в напрямку поширення знань.

Розвиток нової моделі бібліотеки «Бібліотека - центр інформаційної грамотності», де, враховуючи різке зростання педагогічного аспекту, бібліотека стає центром е-навчання, існує в окремих європейських ВНЗ, таких як університет Преторії в Південно-Африканській республіці та Каролінський університет в Швеції $[19,21]$. Педагогічна модель розвитку бібліотеки, обумовлена іiі інформатизацією, передбачає, з одного боку, навчання студентів та докторантів основам інформаційної культури, 3 другого, стимулює розвиток бібліотечних функцій з обслуговування користувачів. Крім того, відбувається розвиток нових форм співробітництва бібліотекарів-викладачів з IT-викладачами навчальних закладів. Така педагогічна діяльність бібліотеки приносить суттєві матеріальні прибутки університетам. Наприклад, бібліотека Каролінського університету Стокгольму (Швеція), організуючи курси з розвитку інформаційної культури не тільки власним студентам і докторантам, а і фахівцям медичної галузі королівства, включаючи бібліотекарів, заробляє близько 1,1 млн шведських крон за рік (це приблизно 140 тис. доларів або 1 мільйон гривень) [21]. 
Модель «Бібліотека - інформаційний ресурсний центр», працюючий в режимі $24 \times 7$, позиціонується як банк ідей в деяких університетах Швеції, Хорватії та Росії $[21,23,8]$. Ця модель передбачає пріоритетне виконання бібліотеками функцій інституційних репозитаріїв як майдану для демонстрації всієї наукової продукції: наукових тез та дисертацій, звітів про науково-дослідні та проектно-конструкторські роботи, трудів конференцій і препринтів та надійного збереження банку інноваційних ідей викладачів, науковців і студентів.

Зміна уявлень про життєвий цикл наукового дослідження та механізми розповсюдження наукової інформації, глобальна колаборація досліджень та дослідницьких ініціатив, зміна парадигми наукової комунікації, зумовлені розвитком інформаційних технологій, і особливо розвитком Web 2.0 приводять до набуття все більшої популярності в Україні аналогічної з попередньою моделлю моделі «Електронна бібліотека: Центри знань в університетах Украӥни» (проект ELibUkr) [18]. Університетська бібліотека виступає не пасивною інституцією збереження знань, а активною учасницею процесів наукової комунікації, організації е-науки та е-досліджень.

Поступово стає актуальною і модель «Бібліотека - інформаційний медіацентр", пов'язана з переходом провідних ВНЗ на новий рівень інформатизації 3 використанням інформаційно-комунікаційних технологій на найвищому їх рівні - медіа $[1,27]$. Поява медіадокументів привела до того, що, наприклад, у Франції деякі книгозбірні відмовились від назви «бібліотека» і отримали статус «Медіатек». Це пов'язано з тим, що поняття «медіа» розповсюджується на всі види документів i, перш за все, на твори друку. У французьких медіатеках твори друку складають до 70\% фонду; інша частина складається з аудіовізуальних та електронних документів. При цьому найбільш престижну свою задачу медіатеки вважають у залученні користувачів до читання саме друкованої книги $[15$, c. 352$]$.

Цікавою є ідея українських науковців Л. Костенка та М. Сороки щодо створення в майбутньому такої моделі бібліотеки як «Інфополіс», поява якої буде об'єктивно зумовлена фактом домінування в інформаційному суспільстві документних потоків на електронних носіях і виокремленням в бібліотечній сфері центрів - генераторів інформації [7]. Інтеграційні процеси, за думкою авторів, будуть посилюватись із розвитком комп'ютерних мереж, і це приведе до об'єднання бібліотек та інших інститутів, які приймають участь у створенні інформаційних ресурсів, в інфополіси. В них будуть здійснюватись не тільки традиційні для бібліотек процеси кумуляції, обробки та використання інформації, але й продукування нових знань на основі цісї інформації. Об'єднання регіональних інфополісів швидкісними каналами зв'язку буде сприяти інтеграції інформації і знань, створених суспільством, і формуванню національних інфополісів як сегментів світового інформаційного простору.

Подальшого грунтовного вивчення потребує i, мабуть, найобговорюваніша в світі, концепція нової моделі бібліотеки - «Бібліотеки 2.0», заснованої на використанні технологій Web 2.0 і для кращого розуміння іiї складових викладена у формулі Дарлін Фічтер: Library $2.0=($ книги и ресурсы + люди + доверие $) \times$ 
участие $[13,20,24]$. Наприклад, для обслуговування студентів та науковців в Університеті Преторія (Південна Африка) в 2006 р. інформаційна стратегія університетської бібліотеки була сформульована так, щоб оптимальне використання нових технологій було чітко сфокусовано на наданні користувачам найсучасніших послуг. Така концепція нової моделі передбачає, що Бібліотека 2.0 - це місце: - де користувачі можуть отримувати те, що вони бажають, а не те, що, за думкою бібліотекарів, вони повинні бажати від бібліотеки; - де відвідувачі не тільки отримують інформацію, але й створюють їі самі [24].

Будь-яка модель сучасної бібліотеки ВНЗ має всі ознаки інформаційного центру. А її місія залежить від зовнішньої та внутрішньої ситуації, навколишнього середовища, пошуку нових підходів до організації основних напрямків діяльності, використання інновацій у поєднанні з практичним досвідом тощо. Всі моделі книгозбірень вищих закладів освіти мають право на існування, але в назві моделі не повинно бути відмови від слова «бібліотека». Бо саме воно асоціюється у читачів/користувачів зі скарбницею інтелектуального, культурного та духовного надбання людства.

Таким чином, сучасна бібліотека ВНЗ, виступаючи певною комунікаційною структурою, має:

- по-перше, документно-комунікаційну сутність власної діяльності, пов'язану з документальними фондами, ресурсами, обслуговуванням;

- по-друге, виступає базовою соціально-комунікативною структурою, яка концентрує комунікаційну культуру суспільства і забезпечує комунікаційні процеси з використанням документів, інформації і знань.

На сьогодення для книгозбірень України, які завдяки системним змінам перетворюються в інформаційні центри ВНЗ, існує ряд реальних і обгрунтованих передумов для створення єдиного інформаційного простору як на рівні регіону, так і на національному рівні: - необхідність в різнобічному й повному доступі до наявних інформаційних ресурсів; - постійне та швидке зростання обсягів інформаційних ресурсів і відсутність можливостей в одній організації задовольнити всі інформаційні потреби своїх користувачів, маючи тільки свої бази даних, фонди тощо; розвиток інформаційних і телекомунікаційних технологій; підвищення вимог до підготовки обслуговуючого персоналу і неможливість мати в кожній організації на постійній основі висококваліфікований персонал.

Соціологічне дослідження «Інтеграція бібліотек ВНЗ України: сучасний стан та перспективи розвитку», проведене нами у січні-березні 2010 р. 3 метою аналізу сучасного стану інтеграційних процесів в бібліотеках вищих навчальних закладів України, дозволило зробити аналіз напрямків і рівнів реалізації комунікаційних стратегій, отримати дані щодо найбільш необхідних та перспективних форм корпоративної взаємодії на сьогодення та окреслити комплекс проблем, які ускладнюють розвиток інтеграційних процесів бібліотек вишів в Україні. Підтверджено, що основна концепція інформаційно-комунікаційної взаємодії університетських бібліотек полягає в організації їх співпраці на основі системи гнучких та варіативних взаємозв'язків з метою створення мережевих інформаційних інфраструктур, структурованого цифрового контенту, корпора- 
тивного сервісу, головною перевагою якого є дистанційний доступ користувачів до об’єднаних бібліотечних інформаційних ресурсів, тощо [5].

Спираючись на дані дослідження, можна стверджувати, що, незважаючи на відсутність доведеної, обгрунтованої системи доказів такого явища, як міжвідомча інформаційно-комунікаційна взаємодія бібліотек вишів України, тобто, відсутність цілісної концепції, яка повинна стати магістральним вектором у формуванні інформаційного середовища держави, аналіз результатів дослідження, їх оцінювання та екстраполяція цих тенденцій на майбутнє дають можливість простежити стійке зростання інтеграції бібліотек ВНЗ. При цьому постійне збільшення їх комунікативного потенціалу, який базується на активній корпоративній діяльності, забезпечує залучення максимально великого кола учасників та необмежені об'єми інформаційних ресурсів.

А. В. Соколов, роблячи екскурс в історію розвитку соціальних комунікацій [12], наводить дані, які дозволяють простежити дію закону прискорення біфуркацій: дистанція між біфуркаціями I і II - майже 4,5 тис. років, між II і III - 400 років; між III и IV - близько 150 років. Тобто, відбувається скорочення «міжбіфуркаційних періодів», яке обумовлене прискоренням історичного часу в стадії неокультури. І цей процес продовжується.

Соціально-історичне прогнозування переваг і складнощів переходу до інформаційного суспільства, визначення місця та ролі бібліотеки в цьому контексті постійно обговорюється на сторінках фахових видань. Наприклад, Шрайберг Я. Л., підкреслюючи тезу про те, що бібліотека майбутнього - це гібридна модель, поєднуюча різні форми інформації та обслуговування, розподіляє еволюційні напрямки науково-освітніх та масових бібліотек. На його думку, освітній компонент бібліотеки розчиниться в освітньому процесі, трансформується в ще одну кафедру або інформаційний центр ВНЗ. Тобто, бібліотеки, які забезпечують освіту і науку, будуть майже електронні, при цьому наукова періодика буде стовідсотково електронною. Сутність же загальнодоступних бібліотек, вважає автор, не зміниться: це буде бібліотека в класичному розумінні, в якій гармонійно співіснуватимуть різноманітні носії інформації [16].

Підсумовуючи вищезгадане, можемо відмітити, що системно-функціональне призначення сучасної бібліотеки ВНЗ пов'язане зі створенням прозорого інформаційно-комунікаційного простору для своїх користувачів, а їі місія полягає в забезпеченні доступу до інформації. Її подальша місія і брендинг при роботі 3 науково-педагогічним складом, науковцями, студентами університетів при переході до когнітивно насичених соціальних комунікацій і становленні ноосферної цивілізації трансформуються в забезпечення формування свідомості соціально активної творчої особистості.

\section{СПИСОК ДЖЕРЕЛ}

1. Бабинская, Н. И. От традиционной библиотеки к информационному медиа-иентру [Текст] / Н. И. Бабинская // Международная конференция «Крым 2005». Библиотеки и ассоџиациии в меняющемся мире: новые тех- 
нологии и новые формь сотрудничества: материаль конф. - Судак, 2005.

2. Великий тлумачний словник сучасної українськоӥ мови / Уклад. $і$ голов. ред. В. Т. Бусел. - К.: Ірпінь: ВТФ „Перун”, 2002. - 1440 с.

3. Ильганаева, В. А. Социальнье коммуникации (теория, методология, деятельность): словарь-справочник [Текст] / В. А. Ильганаева. - Х.: КП «Городская типография», 2009. - 392 с.

4. Ільганаєва, В.О. Місія бібліотеки в комунікаційному просторі сучасності [Текст] / В.О. Ільганаєва // Библиотека ВУЗа на новом этапе развития социальных коммуникаций: материаль междунар. науч.-практ.конф., Днепропетровск, 22-23 апр. 2010 г. - Д.: Изд-во Днепропетр. наи. ун-та железнодор. трансп. им. акад. В. Лазаряна, 2010. - с. 10-14.

5. Колесникова, Т. А. Интеграция библиотек вузов Украины: современное состояние и перспективы развития [Электронный ресурс] / T. А. Колесникова // Библиотеки и информационные ресурсы в современном мире науки, культуры, образования и бизнеса: материаль междунар. конф. «Крым 2010»-M.: ГПНТБ, 2010. - 1 CD-R. - Загл. с этикетки диска.

6. Колесникова, T. О. Інформатизація як умова системних змін в бібліотеках ВНЗ [Текст] / Т. О. Колесникова // Вісник Харківської державної академії культури: зб. наук. праџь. Вип. 26. - Х.: ХДАК, 2009. C. 165-172.

7. Костенко Л. Й. Бібліотека інформаціийного суспільства [Текст] / Л. Й. Костенко, М. Б. Сорока // Бібл. Вісник. - 2002. - № 3. - С. 38-41.

8. НГПУ: Библиотека [Электронный ресурс]. - режим доступа:

9. http://www.nnspu.ru/libraru

10. Півняк. Г. Національний гірничий університет: відповідність часу [Текст] / Геннадій Півняк // Вищза школа. - 2009. - № 2. - С. 3-14.

11. Российская библиотечная ассочиаџия. Секция библиотек высших учебных заведений. Перспективный план работы на 2007-2010 г2. [Электронный ресурс] - Режим доступа: http://www.rba.ru/or/comitet/04/plan.doc

12. Российская библиотечная ассоциаџия. Секция сельскохозяйственных библиотек. Модельный стандарт деятельности библиотеки научноисследовательского учреждения Россельхозакадемии (проект) [Электронный ресурс] - Режим доступа : http://www.rba.ru/conference/tomsk/ modstandart.doc

13. Соколов, А. В. Общзая теория социальной коммуникации: Учеб. пособие [Текст] / А. В. Соколов. - СПб.: Изд-во Михайлова В. А., 2002. - 461 c.

14. Солов'яненко Д. Бібліотека 2.0 - концепиія бібліотеки другого покоління [Текст] / Д. Солов'яненко. - Бібл. вісник. - 2007. - № 5. - С. 10-20.

15. Статистичний щорічник Дніпропетровської області за 2008 р. - Д.: Головне управління статистики у Дніпропетровській обл., 2009. - 519 с.

16. Столяров Ю. Н. Эволючия библиотечного фондоведения [Текст] / Ю. Н. Столяров, Н. Н. Кушнаренко, А. А. Соляник. - М.: «Издательство $\Phi А И Р », 2007 .-688$ c. 
17. Шрайберг, Я. Л. «Американская мечта» в библиотечном формате [Текст] / Я. Л. Шрайберг // Университетская книга. - 2010. - № 5. c. 22-27.

18. Ярошенко Т. Університетська бібліотека в інформаційному суспільстві [Текст] / Т. Ярошенко // Бібліотечний форум Украӥни. - 2006. - № 2(12). - c. 34-38.

19. Ярошенко T. A. Проект ELibUkr «Електронна бібліотека: Центри знань в універ-ситетах України»: иілі, завдання, пріоритети [Электронный ресурс] / Т. А. Ярошенко // Библиотеки и информационные ресурсы в современном мире науки, культуры, образования и бизнеса: материаль конф. М.: ГПНТБ, 2009. - Режим достуnа: http://www.gpntb.ru/win/interevents/crimea2009/disk/132.pdf]

20. Agyei V. From libraries to e-learning centres: a South African library experience [Virtual Resource] / Vivian Agyei // World Libraru and Information Congress: $73^{\text {rd }}$ IFLA General Conference and Council, 19-23 August 2007. - 7 p. - Access Mode: http://www.archive.ifla.org/IV/ifla73/papers/111-Agyeien.pdf

21. Fichter D. Library 2.0 [Virtual Resource] / Darlene Fichter. - Access Mode: http://www/flicr.com/photos/fichter/1148 99622/

22. Herron D. Pedagogical development at Karolinska Institute University Library (KIB) - a management perspective [Virtual Resource] - Access Mode: http:/vefir.unak.is/ckiii/dh_kib_paper-iceland2003.pdf

23. Masuda Y. The Information Society as Postindustrial Society. - Walsh: World Future Soc., 1983. - 248 p.

24. Mihalić M. A Model of the University of Zagreb library system [Virtual Resource] / urednica i koordinatorica projekta Marina Mihalić ; suradnici na projektu Sonja Avalon ... [et al.]. - Access Mode:

http://www.nsk.hr/UserFiles/File/dokumenti/tempus/knjiga\%20modeli.pdf

25. Pienaar H. Development of a Library 2.0 service model for an African library [Virtual Resource] / Heila Pienaar, Ina Smith // World Libraru and Information Congress: $73^{\text {rd }}$ IFLA General Conference and Council, 19-23 August 2007. - Access Mode: http://www.archive.ifla.org/IV/ifla73/papers/146Pienaar_Smith-en.pdf.

26. Soong S.C. Revitalizing Academic Libraries for the 21st Century [Virtual Resource]. - Access Mode: http://www.library.brandeis.edu/beijing_conference/ SamsonSoong.doc.

27. University of Minnesota Profile (ARL) [Virtual Resource]. - Access Mode: http://www.directors.arl.org/files/uminnesota.pdf-

28. Концепция работы научно-технической библиотеки Самарского государственного аэрокосмического университа им. акад. С. П. Королева в условиях медиа-центра: [Электронный ресурс] - Режим доступа: http://lib.ssau.ru/rules 


\section{5. НАУКОВА БІБЛІОТЕКА НУВГП В ІНФОРМАЦЙНОМУ СУС- ПІЛЬСТВІ: ІННОВАЦІЇ, СТРАТЕГІЇ, ТЕХНОЛОГІЇ}

Серед найважливіших ознак, які характеризують інформаційне суспільство наявність системи гігантських взаємопов'язаних накопичувачів інформації, загальнодоступних банків знань і даних і необхідних для їх використання технологічних засобів.

Обраний Україною інноваційний шлях розвитку вимагає випереджувального розвитку науки, освіти, нових технологій, тобто саме тих сфер соціальної активності суспільства, де виробляються і використовуються нові знання, а також сучасна науково-технічна, економічна і соціальна інформація.

3 деяким відставанням, але все ж таки світові тенденції інтеграції інформаційних ресурсів проявляються і в розбудові інформаційного простору України.

Процеси інформаційної технологізації суспільної діяльності динамічно проявляються в бібліотечній сфері, що обумовлює іiї інтеграцію до комунікаційної сфери сучасного суспільства. Інтеграція технологій на рівні техносфери суспільства вимагає ретельного дослідження як загальних тенденцій, так і їхнього впливу на структурно-функціональну трансформацію бібліотек як одного з головних елементів інформаційної інфраструктури суспільства. На необхідність дій у цьому напрямку вказують явища бібліотечної діяльності, такі, як: електронні бібліотеки, електронні ресурси, конвертація друкованих ресурсів в електронні, сервіс в Інтернеті тощо. Всі ці явища і факти створюють нову реальність діяльності бібліотечних організацій. Нові об'єкти, вимагають нових підходів до їхнього вивчення, організації й управління.

Водночас розвиток технічних систем із кін. ХX ст. набуває таких особливостей:

-швидке накопичення науково-технічного знання у сфері обробки інформації і створення більш складних інформаційно-комунікаційних комплексів, що грунтуються на глобальних засобах зв'язку;

-скорочення строків упровадження інновацій від 3-х до 1,5 років;

-зростання комунікаційної залежності соціальних суб'єктів і соціальних систем. Збереження, відтворення розповсюдження, доступ до інформації, споживання інформації в соціумі визначають можливості країни соціальнокультурного, соціально-економічного розвитку і функціонування в умовах глобалізації суспільного життя людства. В цих умовах упровадження новітніх технологій, передусім інформаційних, стає складним завданням і потребує певних обгрунтувань як стратегії і об'єкта управління.

Розвиток інфотехносфери посилює вплив зовнішніх факторів на внутрішню організацію бібліотек. Тенденції розвитку інфотехносфери суспільства значно посилилися за останні роки і зумовлюють нові завдання в реалізації стратегій початкового періоду інформатизації бібліотечної сфери. Інформаційні комунікаційні технології, що стали новими досягненнями останніх десятиліть і з якими пов'язується майбутнє бібліотек.

В Україні активно ведеться процес інформатизації бібліотек, який першочергово розпочався з формування (створення) електронних каталогів (ЕК). Про- 
цес впровадження інформаційних технологій у діяльності українських бібліотек, який розпочався на початку останнього десятиріччя минулого століття, першочергово був спрямований на каталогізацію - створення електронної пошукової системи.

Сукупність каталогів та картотек різних типів (алфавітний, систематичний, предметний, систематична картотека статей, картотека періодичних та продовжуваних видань та ін.) становлять єдину інформаційно-пошукову систему бібліотеки за різними параметрами відображення та пошуку документноінформаційних ресурсів у фонді бібліотеки. Створення та завдання електронного каталогу спрямовані на те, щоб він увібрав у себе всю параметральність відображення та пошуку документно-інформаційних ресурсів (автор, назва, видова, типологічна та мовна специфіка, хронологічні межі, класифікаційний індекс, предметна рубрика, ключові слова та ін.) у бібліотеці.

Стрімкий розвиток мережевих технологій веде до перерозподілу функцій соціально-комунікаційних структур суспільства, що зберігають, розповсюджують і обробляють документалізовану, в тому числі і електронну інформацію.

Технологічні інновації, які здійснюються у вертикально інтегровані бібліотечні структури вплинули на технологічне оновлення виробництва за всіма напрямками діяльності комплектування, обробки, збереження, сервіс, а також на створення і розширення нових напрямків діяльності бібліотеки (електронні ресурси, мережевий сервіс, в т.ч. online пошук, аналітична діяльність, управління знаннями тощо).

Світова глобалізація відносин в усіх сферах життєдіяльності, стрімкий розвиток інформаційних технологій, збільшення потоків інформаційних ресурсів, переорієнтація споживачів інформації спонукає консервативний бібліотечний інститут шукати нові моделі, шляхи та напрями своєї подальшої ефективної роботи. Відбувається переосмислення ролі і місця бібліотечно-інформаційної установи в задоволенні інформаційних потреб і запитів нового сучасного користувача. Для досягнення поставлених цілей Наукова бібліотека НУВГП потребує інновацій, у значному удосконаленні та кардинальній заміні існуючих інструментів i механізмів задоволення інформаційних потреб $\mathrm{i}$ запитів користувачів, у віднайденні нових форм, видів і методів інформаційного обслуговування, в створенні нових інформаційних продуктів і запропонуванні нових видів інформаційних послуг, а також у формуванні нових видів інформаційних ресурсів.

Діяльність з інформаційного забезпечення є важливою ланкою будь-якого навчального закладу. Цю роль традиційно виконує наукова бібліотека НУВГП. Відомо, наскільки ії інформаційний простір відповідає запитам користувачів, настільки успішною стає робота вищого навчального закладу.

Сьогодні, коли підвищилась соціальна та інформаційна роль бібліотек у сучасній освітній діяльності, виникла необхідність формування нових методів організації інформаційного простору наукової бібліотеки НУВГП, яка реалізується на базі комп'ютерних технологій, 3 метою підвищення рівня інформатизації навчального закладу. 
Програмно-практична діяльність, стала визначною в реалізації стратегій у бібліотечно-інформаційні сфері. Необхідність впровадження автоматизації бібліотеки зумовлена інформатизацією суспільства, а також створює передумови входження бібліотечно-інформаційних ресурсів у сукупний інформаційноінтелектуальний потенціал суспільства.

Історія бібліотеки починається з 1922 р. одночасно з історією Київського меліоративного технікуму, а пізніше, відомого тривалий час на території колишнього СРСР як Київський гідромеліоративний інститут. Бібліотека зростала $\mathrm{i}$ мужніла разом з ним. У 1959 бібліотека разом із інститутом переїхала до м. $\mathrm{Pi}-$ вне.

Наукова бібліотека НУВГП сьогодні - це 843797 прим. літератури (в тому числі 432868 українською мовою); біля 562992 прим. підручників; більш 130 тис. наукової літератури; біля 40 тис. в довідково-інформаційному фонді; широка палітра періодичних видань - 1800 назв; щорічне поповнення фонду до 31 тис. прим. Сьогодні це краща технічна бібліотека Рівного. Маємо унікальний за змістом фонд з питань цивільного будівництва, водного господарства, водних ресурсів, архітектури, екології, енергозбереження, екологічного управління, гідротехніки, механіки, прикладної математики та комп'ютерних технологій та ін. Майже 3 тис. прим., нараховує колекція цінних та рідкісних книг. Особливу цінність становлять видання XIX - поч.. XX ст., перший з них датовано 1884 р.

Важливим етапом у діяльності бібліотеки було забезпечення доступу до електронного каталогу та БД через власний веб-сайт. Це дало можливість віддаленим користувачам дізнаватися про наповнення іiі фондів і сприяло збільшенню кількості замовлень на повнотекстову інформацію. Забезпечено доступ до ЕК книг, періодики, авторефератів дисертацій, депонованих робіт. Усі БД систематично оновлюються та проводяться періодичні заходи з резервного копіювання. Розкриття ресурсів Наукової бібліотеки НУВГП віддаленим користувачам через Інтернет збільшує попит на електронну доставку документів.

Документні фонди бібліотек, у т.ч. нашої, зазнають значних змін під впливом електронного середовища. Електронні документи стають усе більш вагомою їхньою складовою.

Іншою не менш важливою тенденцією у використанні Інтернет бібліотекою $\epsilon$ надання інформаційних ресурсів інших установ своїм користувачам. Доступ до Інтернет розширює довідково-бібліографічний апарат бібліотеки, і його складовими частинами стають всі наявні в мережі бібліографічні, довідкові, енциклопедичні видання, в т.ч. електронні каталоги найбільших бібліотек, бібліографічні БД, авторитетні енциклопедії, словники і довідники. Бібліотека може зекономити час своїх користувачів, який вони витрачають на пошук необхідної інформації, і рекомендувати найбільш популярні та якісні довідкові, фактографічні й інформаційні сайти мережі.

Наукова бібліотека НУВГП входить в десятку найкращих вузівських бібліотек України. Це одна з найбільших вузівських книгозбірень західного регіону.

Наукова бібліотека НУВГП загалом включає бібліотечні пункти в навчально-консультаційних центрах: Кримському, Слов'янському, Закарпатському та 
Прилуцькому, та бібліотеки окремих структурних підрозділів університету, які мають окремі фонди та фінансування:

- бібліотека автотранспортного технікуму;

- бібліотека технікуму технології та дизайну;

- бібліотека технічного коледжу;

- бібліотека Костопільського будівельно-технологічного технікуму.

Наукова бібліотека $\epsilon$ методичним центром, центром культурнопросвітницької роботи університету, інформаційною базою науково-дослідної роботи вчених, аспірантів, студентів. Наукова бібліотека НУВГП обрала основним напрямком своєї роботи впровадження концепції сучасної бібліотеки, яка б відповідала вимогам часу, забезпечувала реалізацію нових освітніх концепцій та технологій навчання і сприяла формуванню позитивної громадської думки щодо користування бібліотекою.

Пріоритетним напрямком розвитку нашої бібліотеки є інформатизація. Зберігаючи 85-річні традиції, бібліотека водночас впроваджує нові інформаційні технології, використовує комп’ютерну програму «УФД/Бібліотека» для створення електронного каталогу. Маємо відкритий доступ до Інтернету, можливість пошуку необхідної інформації за попереднім замовленням.

В 2000 р. було прийнято рішення та зроблено першу спробу створення Проекту автоматизації бібліотеки. 32002 р. бібліотека використовує в своїй роботі інноваційні методи, такі, як - автоматизація бібліотечних процесів та активні інформаційні технології, у тому числі Інтернет. Була організована комп'ютерна мережа та АБІС на базі 5 комп'ютерів, які використовувались як АРМ для співробітників. На сьогоднішній день в бібліотеці є 17 ПК, з яких 14 використовуються як АРМ для співробітників, одне робоче місце для читачів, а один - як сервер. 13 ПК мають доступ до Інтернету. Після відкриття в 2006 році Webсайту бібліотеки (http://nuwm.rv.ua/book.php) в якому є сторінка «Електронний каталог» кожен бажаючий може ознайомитись 3 ним 3 будь-якого комп'ютера. ЕК бібліотеки стає все досконалішим, функціональнішим та зручнішим - як для каталогізатора, так й для користувача. Також слід відзначити й ті фактори досконалості ЕК, що обумовлені загальною еволюцією інформаційних технологій. Адже зросла потужність та функціональність комп'ютерної техніки, операційних систем, відповідних програмних та апаратних засобів, арсенал яких постійно розширюється та стає доступнішим для користувачів.

З 2007 року в бібліотеку стали надходити електронні варіанти підручників викладачів університету і на кінець 2009 року на сайті бібліотеки їх виставлено 101 назва. Електронна бібліотека працює в локальній мережі університету.

Перший рівень у системі електронних інформаційних ресурсів - власний ЕК. Сьогодні в ньому більше 11 тис. прим. Кожна назва документа звірена з ЕК та АСК на дублетність.

Електронні БД формуються за такими принципами: за видом документа: «Методичні посібники викладачів НУВГП», за цільовим призначенням: «Електронна картотека статей», «Нові надходження», «Періодика». Регулярно поповнюється картотека «Праці викладачів НУВГП». 
3 усіма представленими сьогодні електронними інформаційними ресурсами можна ознайомитися на сайті нашої бібліотеки. Сайт покликаний служити просуванню бібліотечної діяльності, насамперед іiї інформаційних і функцій, і просуванню навчального закладу, в якому вона знаходиться, з метою реалізації його основних освітніх цілей.

Інформація на Web-сайті регулярно оновлюється та поповнюється.

У 2009 році з ініціативи бібліотеки відбувся відкритий огляд-конкурс навчальних підрозділів університету «Навчально-методичне забезпечення та новітні технології навчання структурних навчальних підрозділів для кредитномодульної системи організації навчального процесу (КМСОНП)».

Гордістю бібліотеки $є$ серія бібліографічних покажчиків «Науковометодичні праці ректорів Національного університету водного господарства та природокористування Рівненського періоду». Ретроспективний покажчик «Рідкісні та цінні документи у фондах НУВГП» (перша частина - «технічні науки» підготовлено в електронному варіанті та надрукований редакційно-видавничим центром. Спільно з музеєм університету готується до випуску біобібліографічний покажчик, присвячений видатному вченому-гідрологу Огієвському А. В. Відредаговано список основних праць Огієвського А. В. та використаних документів відповідно до стандартів та правил бібліографічного опису.

31950 р. ведеться картотека «Праці викладачів НУВГП» в традиційному варіанті, а з 2006 в електронному варіанті.

Для наукової роботи бібліотеки по темі: «Історія бібліотеки з моменту його заснування» проводиться дослідження архівних матеріалів в Рівненському обласному архіві та університетському. Був організований семінар «Відкритий доступ до електронної версії книг через Інтернет». Цей новий проект був представлений видавництвом «Центр навчальної літератури».

Одним із пріоритетних напрямків нашої роботи $є$ розширення інформаційно-бібліотечного сервісу для забезпечення якісного та оперативного задоволення будь-якого попиту з питань наукового процесу. Бібліотека, як провідний підрозділ вузу, має найбільш сконцентровані в єдиному місці ресурси, які спроможні задовольнити різноманітні запити читачів: науковців, викладачів, аспірантів та студентів-дипломників. Регулярно проводяться Дні бібліотеки на кафедрах з основ інформаційної культури.

Наукова бібліотека НУВГП особливе значення надає педагогічному напрямку у роботі, яка реалізується через організацію читань студентів, просвітницьку інформаційну діяльність, навчання студентів бібліотечно-бібліографічній грамотності і формування інформаційно-бібліотечної культури.

Формуючи інформаційно-бібліографічну культуру студента, ми надаємо йому елементарні знання в галузі науково-технічної інформації, бібліотекознавства і бібліографії, які виражаються в умінні орієнтуватися в інформаційно-бібліографічних ресурсах (традиційних і електронних), в знанні їх особливостей і правил доступу до них, в умінні раціонально провести пошук по ДБА бібліотеки (традиційних каталогах і картотеках, електронному каталогу, БД, в мережі Інтернет), в умінні бібліографічно грамотно оформити бібліографічну частину учбової і наукової роботи. 
Признаючи важливість формування у студента інформаційнобібліографічної читацької культури, бібліотека відводить важливе місце цьому аспекту діяльності. Кожному спеціалісту і вченому ясно, що інформаційна «недостатність» сьогодні є відлунням технічної відсталості завтра.

Аналіз бібліографічної частини дипломних, курсових робіт, учбовометодичних матеріалів, що видаються у вузі, стало основним направленням в нашій науково-методичній діяльності. Особлива увага звертається на оформлення бібліографічної частини і широту названих джерел. Відсутність необхідного об'єму знань з основ інформаційно-бібліографічної грамотності, особливо практичних навичок роботи ДБА, а сьогодні необхідно навчити студентів не лише пошуку інформації по традиційних джерелах, але і на електронних носіях включаючи Інтернет.

Наукова бібліотека НУВГП за єдиним читацьким квитком обслуговує за рік 15 тис. користувачів, а всіма структурними підрозділами більше 35 тис. користувачів.

В 2009 році почалась підготовка до електронної книговидачі в читальному залі: налаштування параметрів системи, створення шаблонів, запис в Базу читачів близько 8 тис. користувачів.

За допомогою термопринтера Zebra LP 2824 були виготовлені штрих коди на всю нову літературу, яка надійшла до бібліотеки (11 тис. шт.), це необхідно для обробки літератури і підготовці до автоматизованого обслуговування користувачів бібліотеки.

Відділ інформаційних технологій та комп'ютерного забезпечення здійснює адміністрування та модернізацію БД бібліотеки. Наповнення, підтримку та супроводження сайту бібліотеки 3 метою довідково-інформаційного обслуговування студентів, магістрів, аспірантів та викладацького складу, а також інших фахівців про діяльність бібліотеки, наявність книг, нових надходжень, передплачених видань засобами мережі Інтернет. Виставлення в локальну мережу університету нормативних документів по профілю університету та повних текстів книг викладачів університету, статей і збірників та вісників виданих в університеті. Проводиться захист інформації на машинних носіях і в інформаційних мережах структурних підрозділів бібліотеки. Наукова бібліотека НУВГП тісно взаємодіє 3 бібліотеками, органами науково-технічної інформації і іншими установами з питань впровадження і експлуатації автоматизованих бібліотечних систем.

Новітні інформаційні технології докорінно змінили в бібліотеках все - від процесу комплектування до появи нових напрямків роботи. Бібліотеки повністю оновлюють свій «інтерфейс», переорієнтовуються вимоги до професійних навичок і вмінь бібліотекарів. Незмінним залишилось єдине - якісне і оперативне інформаційне забезпечення наукового та навчального процесів.

В останні десятиріччя у сферу бібліотекознавчих досліджень та практичної діяльності стрімко ввійшов термін «віртуальна реальність». Для обслуговування нової генерації споживачів інформації, які використовують переваги віртуального пошуку, виникли нові види послуг: пошук в електронних каталогах, ви- 
ставлених на сайтах бібліотек; віртуальне довідково-бібліографічне обслуговування, віртуальні виставки. Саме віртуальні бібліотечні виставки, як новий засіб популяризації фондів, забезпечують користувачів ілюстрованою бібліографічною та фактографічною інформацією, доповнюючи іiї повними текстами та довідковими статтями з Інтернету. Віртуальні виставки надають користувачеві більші пошукові можливості, ніж бібліографічні посібники, представлені на сайтах бібліотек.

Сьогодні ми вже розуміємо, що нам потрібно об'єднати зусилля. Єдина інформаційна політика нам необхідна для вирішення на державному рівні питань створення корпоративної мережі вузівських бібліотек, для координації ефективного використання інформаційних ресурсів освітніх закладів та створення Центру корпоративної каталогізації. Таким чином, роль Наукової бібліотеки НУВГП в розвитку інформаційної інфраструктури суспільства передусім пов'язаний із опануванням технологій інформаційного суспільства та інтеграцією бібліотеки до інфотехносфери соціуму. Формування електронного внутрішнього бібліотечного середовища зміцнюють бібліотеку, вона стає інтегратором структурно-функціональних перетворень i носієм розвинутих соціальнокомунікаційних функцій бібліотеки.

Найважливішими завданнями Наукової бібліотеки НУВГП на наступний період $є$ :

-впровадження технології штрих-кодування читацьких квитків та нових надходжень до фондів Бібліотеки;

-впровадження системи електронної книговидачі;

- ретроспективна конверсія каталогів;

-забезпечення доступу користувачів до найбільш значущих повнотекстових електронних баз даних у галузі науки і техніки. 


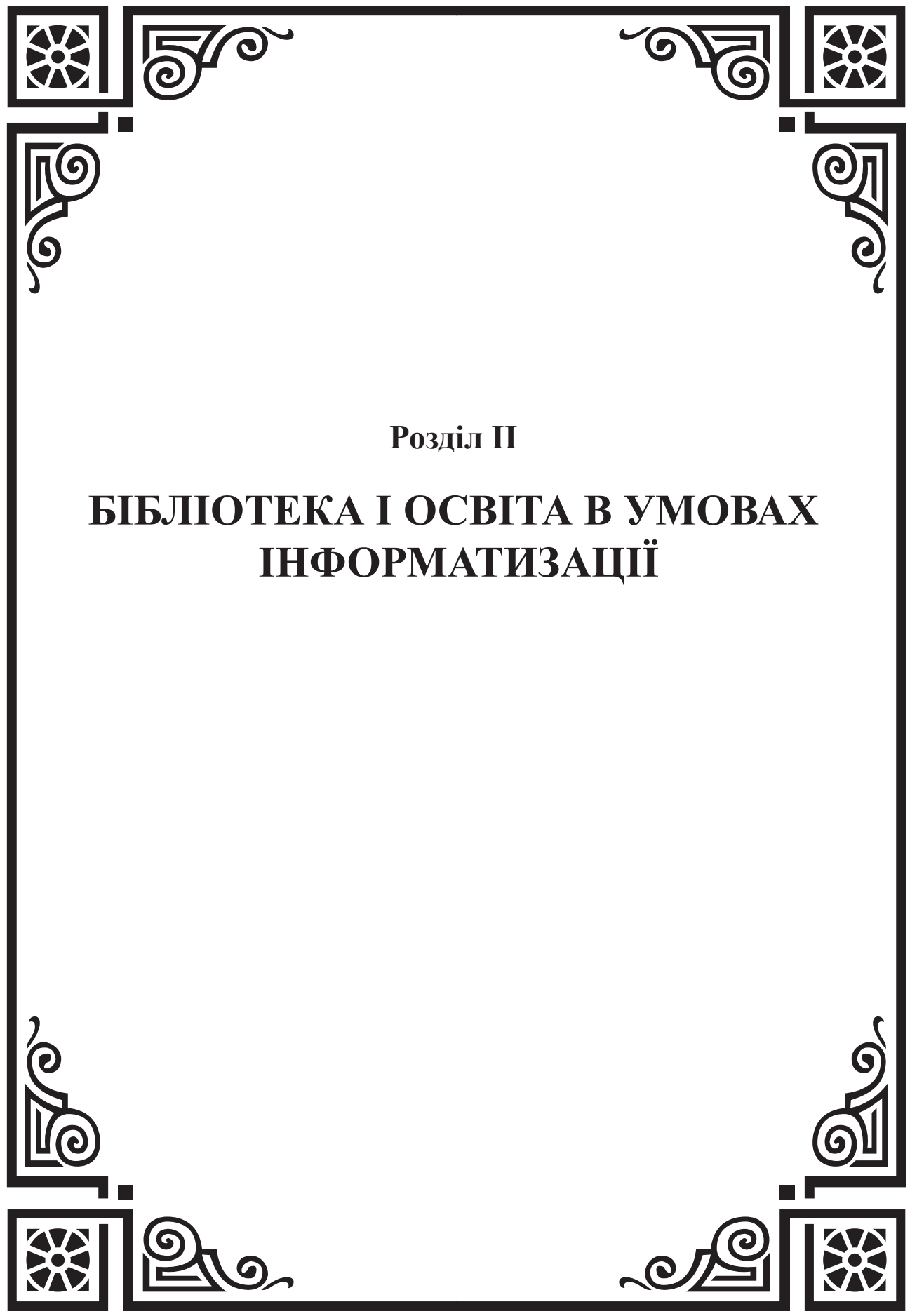




\section{1. ВПЛИВ ІНФОРМАТИЗАЦІЇ НА СТАН РОЗВИТКУ БІБЛІОТЕК BH3}

Розглядаючи на концептуальному рівні мету інформатизації вищого навчального закладу в досягненні позитивних змін його внутрішньої соціотехнічної підсистеми, проаналізуємо проблему «Інформатизація освіти і бібліотеки та роль бібліотек ВНЗ у ії вирішенні». Системний розгляд основних факторів впливу на трансформаційні зміни книгозбірень вищої школи: формування інформаційного суспільства, реформування системи вищої освіти, переосмислення діяльності бібліотек у процесі становлення нової культурної реальності, розробка інноваційної бібліотечної політики та стратегії, визначення складових інформатизації бібліотек і впровадження їх в практику роботи, доводить, що відповідно до трансформації навчального закладу трансформується і його бібліотека. Зупинимося на аналізі цих факторів детальніше.

Система вищої освіти в усьому світі - це сфера, де акумулюється вся інформація, накопичена суспільством, та генеруються головні продуктивні сили. Icнує причинно-наслідковий зв'язок між становленням інформаційного суспільства i кардинальними змінами в освіті. IC не випадково називають «суспільством, що навчається». Навчальні заклади акумулюють і розподіляють інформацію - нове знання i, тим самим, створюють як розумове середовище, де циркулює подібне знання, так і людей, його носіїв. Відповідно можна сказати, що саме інформаційне суспільство створюється у тому числі освітою, бо вона підтримує сам спосіб здобуття, обробки і розподілу інформації [16].

В контексті дослідження питань інформатизації вищої освіти і бібліотеки як iï складової визначальною $є$ характеристика інформаційного суспільства, в якому: підгрунтям стратифікації соціуму стає дійсне володіння інформацією, яке визначається такими якостями людини, як інтелектуальні здібності і освіченість; суспільство, яке на перші місця в ряду цінностей висуває кваліфікацію, професійність та здатність людини до творчості. Видатний американський соціолог Д. Белл вбачає в теоретичних знаннях стрижень, навкруги якого будуть організовані нові технології, економічне зростання та соціальна стратифікація [2, c. 152].

Тому важливим завданням сьогодення $є$ формування інтелектуальної еліти, здатної очолити, розвивати, вдосконалювати виробничі, наукові, освітні, культурні процеси регіону та країни. Найбільш розвинені виші України, як і провідні університети світу, під впливом факторів інноваційного розвитку перетворюються на економічні корпорації, пов'язані з наукомістким виробництвом i поширенням знань. В таких ВНЗ усі ланки університетських структур самовизначаються за ознаками конкурентоспроможності й прибутковості. Організаційна форма для такої інтеграції грунтується на ідеї дослідницьких університетів, які створюють єдине освітнє-наукове середовище, де наука передає для навчання останні досягнення, формуючи передовий зміст освіти. Освітня компонента, в свою чергу, наповнює наукову сферу інтелектуальною молоддю з метою підготовки майбутніх вчених, володіючих сучасною методологією науки. В таких 
університетах практично зникає межа між дослідженнями i дипломною/курсовою роботою, між викладачем та ученим [17, с. 11].

Інформатизація системи освіти, узгодженої з потребами і можливостями сучасного інформаційного суспільства, - невід'ємна складова

інформатизації суспільства, яка виступає в якості інформаційної і комунікаційної основи реформування освітянської галузі.

До теоретичних аспектів розкриття теми належить визначення поняття „інформатизація". За визначенням російського видання «Библиотечная энциклопедия» (рос.) «Информатизация - процесс движения информации, ее получение, внедрение, распространение» [3, с. 415]. Поняття «інформатизація», надане українськими науковцями, є більш розширеним і конкретизованим: у загальному вигляді визначається як сукупність взаємопов'язаних організаційних, правових, політичних, соціально-економічних, науково-технічних, виробничих процесів, що спрямовані на створення умов для задоволення інформаційних потреб громадян та суспільства на основі створення, розвитку і використання інформаційних систем, мереж, ресурсів та інформаційних технологій, які побудовані на основі застосування сучасної обчислювальної та комунікаційної техніки [5, с. 403]. У цьому формулюванні чітко вказана мета цього процесу - задоволення інформаційних потреб як окремих громадян, так і суспільства в цілому. Визначено і метод досягнення даної мети - завдяки створенню, розвитку і використанню інформаційних систем, мереж, ресурсів та інформаційних технологій.

Інформатизація вищої школи як діяльність, спрямована на інформаційнетехнологічне забезпечення процесів наукової, навчальної та адміністративної діяльності, повинна забезпечити: підвищення якості освіти, одним із основних показників якої є затребуваність випускників при працевлаштуванні і конкурентноздатність їх знань/компетенцій на ринку праці, та підготовку компетентного випускника.

Одними з перших серед структурних підрозділів в інформаційно-когнітивні процеси ВНЗ активно включаються бібліотеки. Внаслідок інформатизації вони зазнають еволюційних трансформацій у напрямі змін технологічного, структурного, організаційного та функціонального устрою, i, забезпечуючи інформаційну підтримку у формуванні інтелектуальної еліти суспільства та залишаючись центрами духовного і інтелектуального спілкування і культури, формують нові моделі функціонування та розвитку.

Еволюційне розгортання процесів інформатизації документноінформаційної сфери, переосмислення діяльності бібліотек у процесі становлення нової культурної реальності, поетапність реформування книгозбірень, соціально-комунікаційний підхід до їх розвитку, документне підгрунтя функціонального устрою бібліотек та гуманістична спрямованість їх діяльності, актуалізація комунікаційних аспектів бібліотек у єдиному інформаційному просторі науки і суспільства, конкретизація завдань по входженню бібліотек до інформаційної інфраструктури суспільства завдяки опануванню технологій інформаційного суспільства (ТIC) детально досліджені в роботах провідних вітчизня- 
них та іноземних науковців - В. Горового, І. О. Давидової, В. О Ільганаєвої, Н. М. Кушнаренко, О. С. Онищенка, I. С. Пилко, М. С. Слободяника, Ю. М. Столярова, А. С. Чачко, Г. В. Шемаєвої.

В бібліотечно-інформаційній сфері процеси інформатизації розвиваються в кількох напрямках, кожен з яких науково обгрунтований працями сучасних вітчизняних та іноземних дослідників. Теоретичні засади трансформації бібліотек розроблені в фундаментальних монографіях В. О. Ільганаєвої, Л. Г. Петрової, М. С. Слободяника, А. С. Чачко. Системні зміни в бібліотечно-інформаційній діяльності спрямовані на вирішення техніко-технологічних, організаційних, функціональних питань та питань управління. Так, вектор спрямування технікотехнологічних змін в цій площині досліджувався в працях Л. I Альошина, В. С. Бабич, Ф. С. Воройського, В. Г. Дригайла, В. О. Ільганаєвої, Л. Й Костенка, І. С. Пилко. Вектор організаційних змін в бібліотечно-інформаційній діяльності став предметом розгляду М. В. Гончарова, О. М. Луганського, К. А. Колосова , П. І. Орлова, Л. Г. Петрової, Я. Л. Шрай-берга.

Процеси інформатизації в напрямку функціональних змін досліджувались H. I. Апшай, А. Галлімором, I. О. Давидовою, М. С. Слободяником, Н. І. Туліною. Презентацію думок стосовно процесів інформатизації бібліотек в напрямку управлінських змін знаходимо в працях І. О. Давидової, В. Г. Дригайла, В. О. Ільганаєвої, В. М. Маркової, М. С. Слободяника, Г. В. Шемаєвої.

Подальше дослідження потребує прийняття до уваги такої історично складеної особливості університетських бібліотек, як їх органічне включення до структури вищої освіти. Н. Апшай, досліджуючи стратегічні аспекти розвитку бібліотек ВНЗ в умовах інформатизації, відмічає, що бібліотека вищої школи розглядається як соціальна інституція, відмінною особливістю якої є взаємозв'язок з системою вищої освіти, а основними типологічними ознаками безпосередня включеність у структуру і систему комунікацій вищого навчального закладу та проблемна орієнтація ресурсів на задоволення інформаційних потреб професорсько-викладацького складу і студентів [1].

Російська дослідниця Т. В. Срьоменко, порівнюючи процеси інформатизації університетських бібліотек Росії та США, доводить, що бібліотеки ВНЗ, гармонійно існуючи у фаховому бібліотечному товаристві, перш за все орієнтовані на задоволення інформаційних потреб вищої школи і є ії підсистемою. Саме це $\epsilon$ особливістю їх інформатизації, яка полягає в підпорядкування цілей і завдань бібліотечного характеру більш глобальним пріоритетам інформатизації освітньої діяльності як цілісної системи [8, с. 22].

Таким чином, інформатизацію бібліотек ВНЗ можна визначити як створення оптимальних умов для задоволення інформаційних потреб вищої школи за рахунок формування, використання та розповсюдження інформаційних ресурсів. I такі оптимальні умови пов'язані тільки зі зміною в усіх складових діяльності книгозбірень. Автоматизація бібліотечних процесів, формування електронних бібліотек, опанування можливостей Інтернет-технологій, налагодження комунікаційних зв'язків у внутрішньо-бібліотечних системах і зовні зі всіма учасниками бібліотечно-інформаційного простору, участь бібліотек у дистанційній 
освіті, оновлення інформаційних продуктів та послуг, формування інформаційної культури фахівців бібліотек і користувачів та інші складові інформатизації торкаються всіх аспектів функціонування бібліотеки як соціальної організації і зумовлюють іiі трансформацію та подальший розвиток. Науково-технічні й організаційно-структурні інновації впливають на місію бібліотеки та мету ії діяльності, наукове пізнання, організаційну структуру та технологію праці, обслуговування і забезпечення інформаційних потреб, економіку, кадри, професійну етику тощо $[4,6,7,8,10,11,12,14,18,22,23]$.

Інформатизація сучасної бібліотеки ВНЗ вбачається спільнотою у впровадженні сучасних інформаційних технологій, які сприяють використанню широкого арсеналу електронних ресурсів, одним з конструктивних елементів якого в контексті Болонського процесу виступає довідкова система у вигляді електронних каталогів, електронних бібліотек, баз даних, репозітаріїв, порталів [9].

Бібліотеки вишів надають своїм користувачам доступ до національних та міжнародних науково-освітніх ресурсів Інтернет, реферативних і повнотекстових баз даних та банків знань, електронних довідників тощо; формують власні електронні ресурси та забезпечують комфортні умови їх використання. Відбувається активізація міжнародної діяльності бібліотек університетів України, орієнтована на максимальне використання світових інформаційних ресурсів та включення національних ресурсів України в світовий інформаційний простір. Тобто, вже можна казати, що трансформаційні процеси в бібліотечноінформаційній сфері від кількісних ознак поступово отримали якісні властивосTi.

Сучасні суспільні інформаційні процеси відзначаються універсальністю. А інформаційно-комунікаційні техніки та технології дозволяють цю універсальність глобалізувати. Це сприяє формуванню на різних рівнях організації бібліотечної діяльності сучасних системних об'єднань - бібліотечно-інформаційних комплексів.

Результати соціологічного дослідження «Інтеграція бібліотек ВНЗ України: сучасний стан і перспективи розвитку» (січень-березень 2010 р), що охопило всі регіони держави, дозволяють стверджувати, що бібліотеки вишів під впливом формування єдиного інформаційно-комунікаційного простору освіти, як підсистеми національного інфопростору, всіма складовими своєї діяльності інтегрують до його системної організації. На підставі отриманих даних ми вважа$€ м 0$, що розвиток ініціатив на місцях сприяє формуванню нових інформаційнокомунікаційних стратегій, які дають можливість простежити стійке зростання інтеграції бібліотек ВНЗ. При цьому постійне збільшення їх комунікативного потенціалу, який базується на активній корпоративній діяльності, забезпечує залучення максимально великого кола учасників та необмежені об'єми інформаційних ресурсів. В той же час аналіз даних дозволяє нам стверджувати, що переважна більшість корпоративних проектів реалізується на регіональному рівні $[12,14]$.

Аналіз літературних джерел та практичні спостереження дозволяють відмітити, що бібліотека вишу, яка, надаючи інформаційну підтримку навчальній, 
науковій та виховній діяльності, традиційно є центром комунікацій різноманітної університетської спільноти, впевнено займає одне з провідних місць в інформаційно-освітньому середовищі навчального закладу. Бібліотека вбудовується в інформаційну мережу ВНЗ, генерує онлайновий продукт, забезпечує доступ до електронного ресурсу, тобто вона вже виступає інформаційним центром університету.

Одним з головних результатів інформатизації в сфері освіти стало впровадження дистанційних форм навчання, які базуються на новій технікотехнологічній базі і креативних методиках навчання, та створення якісно нового освітнього середовища. Бібліотеки, як компонент цього інформаційноосвітнього середовища, реагують на ці виклики сучасності впровадженням трансформаційних змін і нових стратегій розвитку, забезпечуючи задоволення інформаційних потреб суб'єктів освітнього процесу шляхом надання доступу до інформаційних ресурсів, та набувають при цьому якісно нової ознаки діяльності - особистісно-орієнтовного підходу. Його суть полягає у визначенні, підтримці і розвитку позитивних якостей студента і формуванні на цій основі механізму самореалізації особистості.

Розгляд впливу інформатизації на стан розвитку бібліотек ВНЗ потребує звернення до думок їх сучасних користувачів.

Масове регіональне соціологічне дослідження „Сучасна бібліотека ВНЗ очима студентів", що охопило молодь десяти вишів Дніпропетровська (березень-квітень 2009 р.), було проведено вперше за останні 30 років і дозволило сформувати відношення студентів до трансформаційних змін в бібліотеках [15]. Отримані дані дозволяють нам стверджувати, що:

- існує чітка тенденція підтримки читачами/користувачами процесів інформатизації бібліотек ВНЗ;

- для сучасної молоді читання все більше втрачає статус естетичного задоволення та перетворюється в засіб отримання інформації;

- основним мотивом звернення студентів до бібліотеки $є$ збір інформації в наукових цілях - для написання доповідей, рефератів, інших наукових робіт та отримання літератури для підготовки до екзамену, семінару, практичної роботи;

- рейтинг традиційних джерел інформування (алфавітного та систематичного каталогів) знизився; найбільш затребуваними елементами довідковоінформаційної системи бібліотеки сучасні студенти вважають доступ до мережі Інтернет та електронний каталог. Це підтверджує ідентичність уподобань студентів різних країн світу у виборі джерел інформування. Згідно 3 результатами дослідження OCLC 2005 р., 84\% студентів університетів США починали роботу над своїми науковими проектами з пошуку інформації на самих популярних сайтах Інтернет-систем [20]. Три роки поспіль, в січні 2008 р. на замовлення Британської бібліотеки було проведене дослідження серед англомовних студентів з розвинених країн Заходу, яке розвіяло багато міфів про взаємини молодих людей з новими технологіями, але отримало докази того, що вже $89 \%$ студентів університетських коле- 
джів розпочинають дослідження зі звичайних пошукових систем, а не 3 сайтів бібліотек, і майже всі вони задовольняються результатами такого пошуку;

- рівень інформаційної культури студентів $є$ недостатнім: досить велика частина респондентів зовсім не мають навичок роботи в інформаційних мережах та з базами даних (19,4 \%). Глобальна мережа розвинула таку негативну рису молоді як неуважність і небажання витрачати час на обдумування знайдених в Інтернеті даних. Тому, плануючи стратегію розвитку кожної бібліотеки ВНЗ, необхідно перенести акцент з безпосередніх технологічних питань впровадження i використання інформаційних технологій на проблеми організації нових форм і напрямків з формування інформаційної культури користувачів;

- основними заходами 3 підвищення комфортних умов для роботи в бібліотеці студенти вважають: покращання комплектування, розширення сервісних послуг (ксерокс, копіювання з електронних носіїв, сканування тощо) та збільшення кількості комп'ютерів для доступу до локальних і мережевих електронних ресурсів;

- отримання позитивної відповіді на дещо провокаційне питання „Чи вічна бібліотека?» розуміється як підтвердження необхідності інтенсифікації трансформаційних системних змін в бібліотеках, удосконалення традиційних бібліотечних функцій та появу нових, які обумовлюють провідну роль бібліотек в інформаційному суспільстві - роль виробника електронних ресурсів та інформаційного посередника і навігатора в інформаційному просторі. Ці факти мають підтвердження в практиці сучасних бібліотек і призводять до перетворення їх в інформаційні інтелект-центри закладів освіти [15].

В умовах сьогодення практика бібліотечної діяльності у вишах доводить залежність між збільшенням електронних ресурсів у відкритому доступі та потребою користувачів у проведенні тренінгів, консультацій та інших форм освітньої роботи бібліотеки. Загострення конкуренції на ринку інформаційних продуктів приводить до швидкої зміни пошукових інтерфейсів баз даних, техніка пошуку необхідної інформації стає все більш витонченою, стрімкими темпами зростають обсяги електронних ресурсів Інтернет. Це неповний перелік, фактів, чому, з точки зору професійної бібліотечної преси інформаційно розвинутих країн, користувачі звертаються за допомогою до бібліотечноінформаційних фахівців як кваліфікованих експертів, навігаторів в безмежжі інформації, менеджерів знань. Новий, більш глибокий і продуктивний рівень взаємозв’язку бібліотекарів з викладачами вишів, наприклад, у створенні завдань для студентів 3 використання і оцінки інформаційних ресурсів або тісна співпраця в проектах дистанційної освіти, $є$ свідоцтвом наповнення освітньої місії бібліотеки іншим змістом. Це змінює і роль бібліотекаря, якому все більше стають притаманні функції інструктора, педагога, тренера $[4,8]$.

Впровадження сучасних освітніх технологій у вищій школі та інформатизація бібліотек ВНЗ взаємозалежні і взаємопов'язані, бо фактично $є$ ланками в 
одному ланцюгу. Саме тому вони розглядаються в єдиному контексті цілей i задач інформатизації освіти. В розвинутих країнах Заходу розгорнуті і успішно діють цільові програми створення цифрових університетів (Digital University), a впровадження нових технологій у навчальний процес спонукало до появи нових концепцій «мега-університету» (mega-university) та «віртуального університету» (virtual-university), які асоціюються 3 середовищами on-line підтримки процесів навчання та викладання, а також імітують традиційні технології організації адміністративної та бібліотечної служби навчального закладу засобами інформаційно-комунікаційних технологій. На відміну від цього, більш радикальною та всеохоплюючою корпоративною стратегією $є$ створення цифрового університету, що передбачає системний аналіз усіх ключових бізнес-процесів в закладі освіти, формування на його основі нового бачення реінжинірингу та вдосконалення цих процесів в on-line середовищі. Побудова цифрового університету вважається як можливість знову продумати архаїчні моделі управління інформаційними потоками та процесами засобами, що більш пристосовані до майбутнього університету [22]. Структура та склад цифрового університету передбачає наявність взаємопов'язаних складових: корпоративного Інтернетпорталу для організації доступу до широкого діапазону інформаційних та комунікаційних ресурсів; студентського Інтернет-порталу; цифрової бібліотеки; публічного веб-сайту; системи електронного навчання.

Кроки в напрямку створення електронних університетів в Україні, які відбуваються на підгрунті їх інформатизації, розглянемо на прикладі Програми комп'ютеризації та інформатизації Дніпропетровського національного університету залізничного транспорту імені академіка В. Лазаряна на 2007-2011 роки „Створення електронного університету” (надалі - Програми). Головна мета Програми - створення електронного університету як сучасного центру Свропейської освіти та науки, в якому широко використовуються інноваційні технології в навчанні та наукових дослідженнях. Електронний університет повинен входити до єдиної мережі університетів України та Свропейського співтовариства в різних напрямках діяльності як інтелектуальний центр підготовки фахівців третього тисячоліття.

Один із окремих проектів Програми цілком присвячений науково-технічній бібліотеці університету і має назву «Розвиток бібліотеки як інформаційного інтелект-центру університету». Цей проект визначає перспективи діяльності НТБ, іiі інноваційну місію у формуванні й розвитку інформаційної інфраструктури університету. Він базується на двох ключових документах - „Концепції розвитку науково-технічної бібліотеки університету на 2007-2011 рр.” та „Плані робіт щодо виконання „Концепції розвитку науково-технічної бібліотеки університету на 2007-2011 pр.”. В цих стратегічно важливих роботах розроблені конкретні заходи з удосконалення інформаційного забезпечення навчальновиховного і наукового процесів в університеті та подальшого розвитку бібліотеки як інформаційного інтелект-центру ВНЗ.

Та чи інша модель бібліотеки, яка еволюціонує в гуманітарному, технократичному або технократично-гуманітарному напрямку, потребує врахування 
специфіки ВНЗ, особливості сучасного стану процесів інформатизації в регіоні та країні, тенденції світових процесів бібліотечно-інформаційного розвитку. Окрема модель розвитку бібліотеки передбачає свою модель інформатизації. Під моделлю інформатизації в даній концепції ми розуміємо систему цілей, завдань, засобів, технологій і результатів інформатизації, яка, відображаючи процес інформатизації, дозволить досліджувати, управляти та прогнозувати розвиток процесів інформатизації в бібліотеці. При цьому відбувається забезпечення спадкоємності в застосуванні традиційних, автоматизованих і інформаційнокомунікаційних технологій (ІКТ). Це $є$ можливим, наприклад, за рахунок того, що компонентна структура ІКТ в технологічній моделі бібліотеки ВНЗ, яка включає технічні (апаратні та комунікаційні) і програмні засоби, інформаційні і кадрові ресурси, нормативну базу і інформаційні продукти/послуги, що представлені на інформаційному ринку, зберігає зміст виробничих бібліотечних процесів, але змінює алгоритми їх реалізації.

При моделюванні структури інформатизації бібліотеки ВНЗ, необхідними компонентами iï $\epsilon$ цілі і завдання інформатизації, при цьому як внутрішні, так і зовнішні. Тому необхідним $\epsilon$ врахування факту залучення бібліотек вишів до двох сфер діяльності - освіти та бібліотечно-інформаційної справи. Власну діяльність ці бібліотеки вибудовують з урахуванням постійних динамічних змін як в суспільстві в цілому, так і в області бібліотечної справи, освіти, науки, інформаційно-комунікаційних технологій, засобів масової комунікації тощо.

При розробці структури моделі інформатизації бібліотеки ВНЗ вважаємо за доцільне використання стратегічних орієнтирів ії розвитку першого рівні реалізації, розроблених Н. Апшай: здійснення моніторингу відповідності інформаційних потреб читачів та інформаційних ресурсів бібліотеки; автоматизація основних технологічних процесів; формування електронної бібліотеки; опанування можливостей Інтернет-технологій; участь бібліотеки в дистанційній освіті; оновлення інформаційних продуктів і послуг; участь у корпоративних бібліотечно-інформаційних системах; підготовка бібліотекарів і читачів для роботи в електронному середовищі.

Враховуючи вищезгадане, можемо представити графічну структуру процесу інформатизації бібліотеки вищого навчального закладу на Малюнку 1.

При цьому треба враховувати, що така модель інформатизації бібліотеки ВНЗ, як і будь-яка інша, потребус: або уточнення цілей і завдань, якщо ії показники не відповідають показникам інформатизації зовнішнього середовища, i передбачає доробку моделі; або переходу на новий виток розвитку, що передбачає постановку нових цілей і завдань.

Таким чином, як ідеологія програми інформатизації бібліотеки будь-якого ВН3, що базується на забезпеченні доступності інформації, суттєво впливає на ідеологію програми інформатизації самого закладу, так стратегія розвитку вузів в цьому напрямку відбивається і у визначенні стратегічних орієнтирів їх бібліотек. 


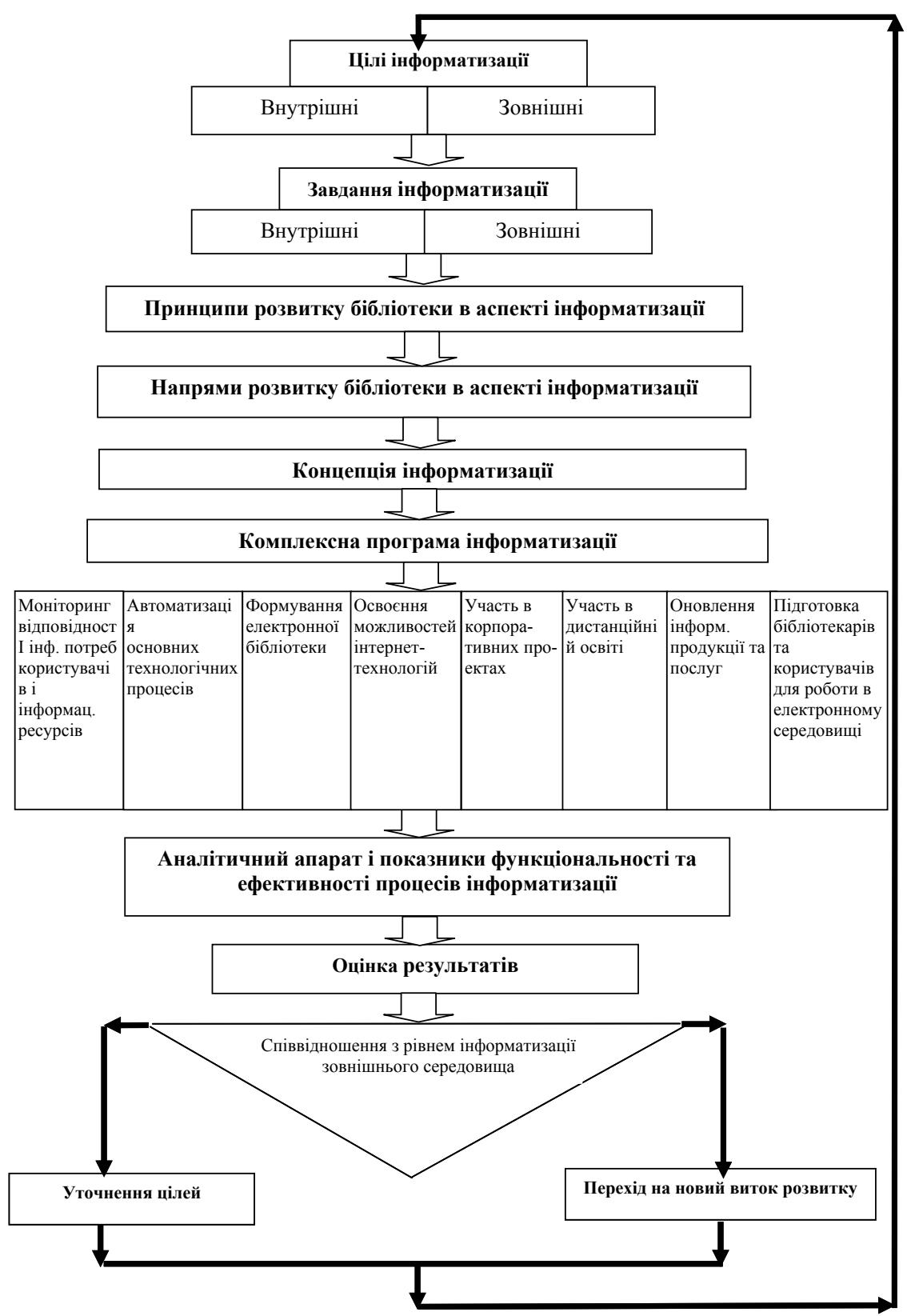

Малюнок 1. Структура процесу інформатизації бібліотеки 
В фахових публікаціях існують окремі ствердження, що стратегії інформаційно-технологічних перетворень в бібліотечно-інформаційні сфері, стан освоєння ними інформаційних технологій, які були пов'язані з повною інформатизацією бібліотек, можна вважати вичерпаними [19]. Аналіз перетворень бібліотечної діяльності в Україні завдяки впровадженню і використанню інформаційних технологій (IT) за останнє майже десятиріччя дозволяє стверджувати, що вони відтворюють аналогічні процеси, які раніше відбувалися в цій сфеpi в зарубіжних бібліотечно-інформаційних структурах провідних країн. Етапи використання IT в книгозбірнях можна умовно поділити наступним чином: початковий, тобто автоматизація внутрішніх процесів з метою звільнення працівників від рутинної роботи; другий - перехід до локальних мереж та створення автоматизованих бібліотечно-інформаційних систем; третій - використання Інтернету та Інтернет-технологій, вихід у світовий інформаційний простір не тільки 3 метою використання інформаційних ресурсів, а й надання доступу до них всім бажаючим. Найбільш затребуваними інформаційними технологіями в практиці роботи бібліотеки ВНЗ слід вважати як базові IT (гіпертекстові, мультимедійні, телекомунікаційні, технології програмування, баз даних, захисту інформації та ін.), так і спеціальні (бібліографічні, архівні, видавничі, музейні, науково-аналітичні, рекламні та ін.) [7].

Зараз ми можемо констатувати, що бібліотеками вишів у період освоєння інформаційних технологій завдяки потужним автоматизованим бібліотечноінформаційним системам опановані наступні кроки:

- комп'ютеризовані всі внутрішні бібліотечні технологічні процеси, засвоєна технологія дистанційного запозичення на основі корпоративної взаємодії бібліотек за протоколами Z 39.50;

- створюються електронні каталоги (включаючи повні ретрокаталоги або імідж-каталоги);

- запроваджена електронна книговидача на основі штрих-кодів або RFIDміток;

- сформовані фонди електронних повнотекстових та мультимедійних документів;

- створено сайти/портали, які забезпечують доступ до каталогів, електронних документів, передплаченим електронним ресурсам 3 можливостями розподіленого пошуку та замовлення електронних копій документів тощо;

- формуються електронні бібліотеки та інституційні репозитарії.

В бібліотеках ВНЗ створено технологічний базис, якій містить практично повністю всі компоненти сучасної інформаційної системи. 3'явилася тенденція зниження ролі традиційної АБІС - вона стає лише одним із багатьох рівноцінних програмних засобів, що використовуються в бібліотеках і інформаційних центрах. Це потребує нових концептуальних рішень на шляху подальшого розвитку бібліотечної автоматизації. В повсякденну практику увійшли як технології генералізації інформації, іiі збереження, обробки, виробництва, розповсюдження та організації доступу до неї, так i інформаційно-аналітичні, інтелектуальні технології. Обов'язковим елементом сучасного вишу $є$ наявність 
електронної бібліотеки, інституційних репозитаріїв, які ініціюються, організуються та керуються бібліотеками і сприяють розширенню уявлень про неї як електронну структуру вищого навчального закладу.

В той же час вітчизняні учені і практики бібліотечно-інформаційної сфери відмічають необхідність подальшого розвитку інформаційно-комунікаційних відносин, активних пошуків і впровадження нових форм взаємодії. Доведено, що інформаційне забезпечення науки та освіти України все ще далеке від бажаного, дослідники і студенти держави не мають рівного доступу до знань, а вітчизняна наука все ще перебуває в певній ізоляції до світової [23].

Тому, найбільш реалістичною, на наш погляд, вбачається думка не про вичерпність стратегій інформаційно-технологічних перетворень, пов'язаних 3 інформатизацією бібліотек, а про констатацію того, що сучасна ситуація в процесах інформатизації бібліотек ВНЗ характеризується як перехідна, тобто, коли окремий, дуже важливий етап роботи можна вважати вже завершеним. I ця відносна завершеність відкриває в перспективі безмежне поле діяльності, з новими можливості та обріями розвитку. Як приклади цього можуть наведені пошуки нових інструментаріїв інтеграції різнопланових інформаційних ресурсів у Webпорталі бібліотеки; забезпечення гнучкої коннективності системи обслуговування локальних користувачів за допомогою всіх трьох можливих на сьогодення технологій: дротової (оптоволоконної або витої пари), WiFi/WiMax і мобільний зв'язок; впровадження інструментарію та визначення важелів впливу в закріпленні за бібліотекою ВНЗ провідної ролі в організації інституційних репозитаріїв та підтримці міжнародного руху з ініціативи архівів відкритого доступу; проведення бібліометричних досліджень як аналітичного інструменту оптимізації наукової роботи ВНЗ.

Підсумовуючи вищезгадане, можемо стверджувати, що підвищення рівня інформатизації та медіатизації, завдяки яким відбулися якісні зміни в соціально-комунікаційній сфері освіти, науки і культури, ще далекі від граничних величин.

I. О. Давидова, досліджуючи бібліотеку як складову інформаційної інфраструктури держави, підкреслює, що в Україні на сьогодення в процесі формування інформаційного суспільства переважно створюється технічна та технологічна структура на шкоду іiі інтелектуальній складовій. Пояснення цього вчені вбачають в факті того, що Україна, маючи один з найвищих в світі індексів освіченості (98\%) і величезний потенціал, залишається країною з низько технологічною промисловістю, слаборозвиненою інфраструктурою та системою інформаційного виробництва. За кількістю населення і площею території Україна належить до групи п'ятдесяти найбільших країн, але за індексом комунікаційної підготовленості (NRI) вона займає лише 70-е місце серед 80 країн, оцінених за цим критерієм [6, с. 20]. Аналогічна думка простежується в публікаціях російського вченого Я. Л. Шрайберга, який вважає, що бібліотеки Росії зрівнялися з бібліотеками США лише в частині оволодіння комп'ютерними технологіями [21].

Незважаючи, що така технологізація діяльності бібліотек взагалі-то розглядається як етап глобальної технологізації інформаційного суспільства та його 
інформаційно-комунікаційної підсистеми, але в той же час науковотехнологічна складова майбутньої епохи зовсім не вичерпує всього соціокультурного простору. Учені фіксують не менш знакові події і в інтелектуальній складовій: зміни світосприйняття людини, підходів у науковому пізнанні, орієнтирів у соціокультурному житті. Культурний вимір формує узагальнюючий погляд на весь інформаційний спектр, який охоплює електронні, телекомунікаційні, медіа- та віртуальні технології, на їх місце і роль у житті сучасного суспільства [11, с. 109].

Таким чином, одним з визначальних фактів впливу інформатизації на розвиток бібліотек в сфері вищої освіти є поява іiі нової організаційної форми - бібліотечно-інформаційного центру (БІЦ). В цьому контексті ретельного спостереження, аналізу та узагальнення потребують зміни в діяльності бібліотек ВНЗ по основним складовим, до яких традиційно відносять: фонди, каталоги, бібліотечно-бібліографічне та інформаційне обслуговування; методичну роботу, матеріально-технічну базу, кадри, управління. Виникнення БІЦ є результатом трансформації книгозбірень на основі процесів автоматизації всіх складових іiі діяльності. Саме це дозволило реалізувати всі основні вимоги до системних інформаційних технологій, а саме: одноразовий вхід предмета обробки, багаторазове його використання, точна спрямованість вузлів концентрації, віддалений доступ, цільовий розподіл, багаторівневий захист інформації тощо.

На нашу думку, БІЦ є новими організаційно-функціональними елементами ВНЗ, завданням яких стає керування процесами функціонування інформаційного середовища закладу освіти через координацію документообігу і документозбереження, створення електронного інформаційного ресурсу, організація доступу до нього, формування умов інформаційного споживання. Слід відмітити, що застосування в бібліотеках комп'ютерної та телекомунікаційної техніки та технологій - це лише початок цієї трансформації, а подальший розвиток бібліотеки як динамічної системи передбачає іiі подальшу еволюцію. Це стає особливо актуальним зараз, коли бібліотеки ВНЗ переходять на новий рівень інформатизації із використанням IКТ на найвищому іiі рівні - медіа технологій.

Ілюстрацією цього може стати схема еволюціонування бібліотечних систем, побудована на основі етапів їх розвитку [18, с. 59] 3 додаванням певних коректив, позначених на схемі «*», за рахунок включення до неї двох рівнів (Малюнок 2).

Слід відзначити, що вікно, розташоване в правому нижньому куті схеми і позначене «Мультимедійні та об'єктні технології» можна вважати точкою розгортання подальшого етапу інформатизації бібліотек - медіатизації.

Розгляд питання щодо інформатизації як головного фактору функціонування бібліотек в соціально-комунікаційному просторі потребує переосмислення уявлень щодо сутності історико-культурних та освітньо-наукових традицій бібліотечної діяльності в суспільстві. Ця проблема торкається і такого аспекту як аналіз ситуації, пов’язаної з процесами міфотворення, та узагальнення сучасних бібліотечно-інформаційних міфів. 


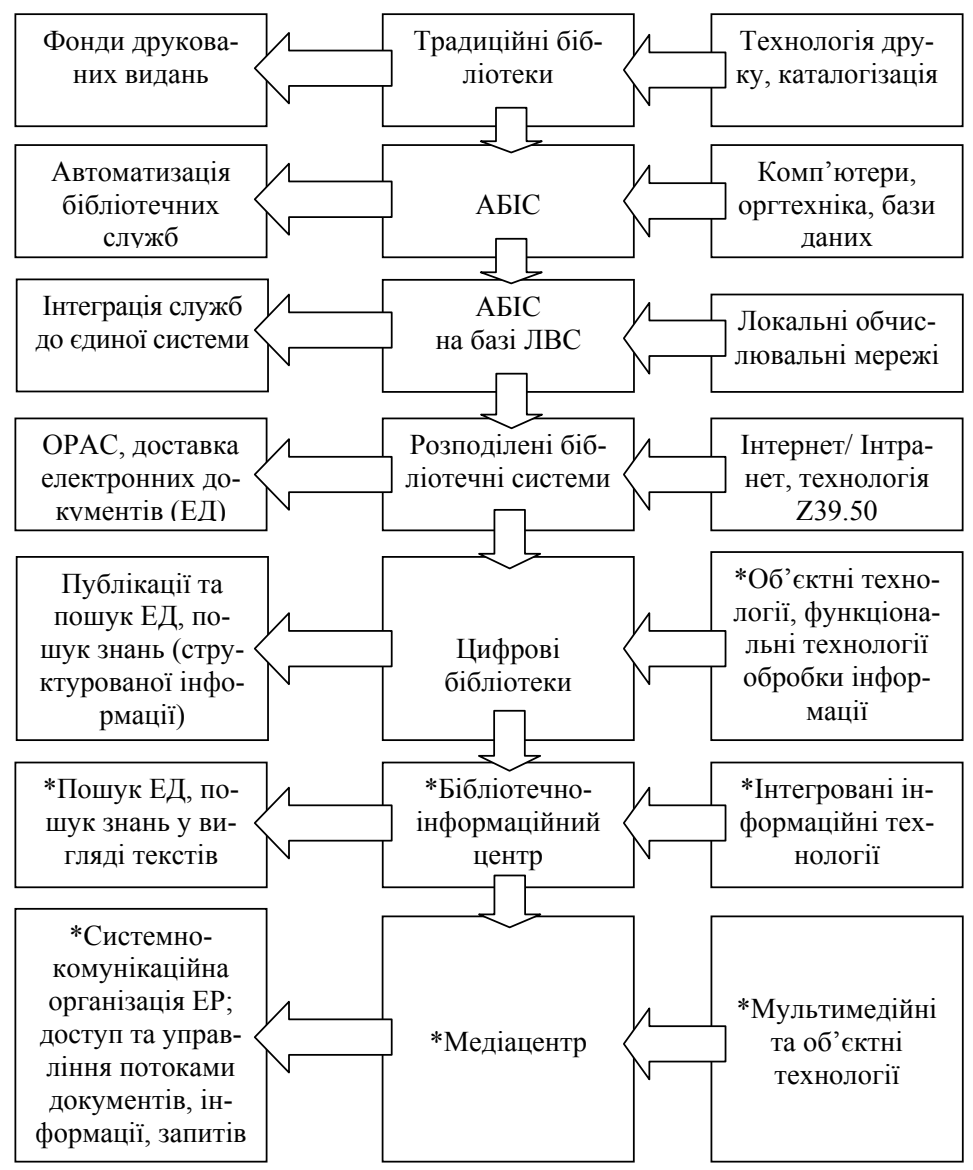

Малюнок 2. Етапи розвитку бібліотечних систем

У вивченні процесів міфотворення в комунікативному просторі накопичено достатньо значний науковий наробок, пов'язаний 3 працями У. Еко, В. О. Ільганаєвої, М. Колесникової, В. П. Леонова, М. Мак-Люена, С. Г. Матлиної, А. В. Соколова, Т. Филиппової, А. Т. Щедрина та ін. В своїх дослідженнях автори розглядають ресурсну та соціокультурну концепції інформаційного середовища як важливе методологічне підгрунтя дослідження буття міфів в просторі соціальних комунікацій, аналізують трансформацію механізму відтворення нових міфів в різних фазах комунікативних технологій, відмічають виникнення ефекту гіпертекстуальності нових міфів. В той же час слід відмітити недостатню розробленість цієї теми українськими фахівцями в області бібліотечної справи. Відсутність комплексного дослідження еволюції виникнення та сучас- 
ного стану бібліотечно-інформаційних міфів на українському підгрунті визначають актуальність розвитку цієї проблеми.

Аналіз результатів соціологічного дослідження «Бібліотечні міфи інформаційного суспільства» [13], проведеного 3 метою аналізу в Україні ситуації, пов'язаної з процесами міфотворення, і узагальнення сучасних бібліотечноінформаційних міфів, дозволяє зробити наступні висновки:

1. Міфологічний вакуум спотворює професійну свідомість. Загублення професійної міфології означає втрату привабливості професії та приниження професійного самопізнання.

2. Сучасні процеси міфотворення, пов'язані з інформатизацією бібліотек, яка розуміє під собою їх насиченість технічними новинками та багатим інформаційним ресурсом, не знищують книжкову культуру, а лише переводять іiї на іншій рівень сприйняття, більш відповідний реаліям інформаційного суспільства. Тим самим вони дають змогу бібліотекам гармонійно існувати в життєвому просторі „покоління Google”.

3. Загальні властивості міфічного мислення (невід'єднаність людини і світу, прагнення до ладу у соціумі та в душі людини, пояснення сутності об'єктів через історію їх творення тощо) дозволяють вважати найбільш поширеними як в суспільстві взагалі, так зокрема і в бібліотечній спільноті міфи:

- Міф про чудо інформатизації;

- Міф „Доступ до Інтернет зробить бібліотеки непотрібними суспільству”;

- Міф про „покоління Google», яке не хоче читати;

- Міф „Моя хата скраю або бібліотечна інтеграція в Україні ще не актуальна”;

- Міф про кінець бібліотечної професії.

4. Модифікації міфів повинна відбуватися: по-перше, через зміну стереотипної бібліотечної свідомості завдяки активним контактам з відмінною від неї дійсністю та через інтенсивне засвоєння нової інформації; по-друге, через усталену бібліотечну практику, засновану на активному впровадженні новітніх засобів і технологій.

5. Розвиток бібліотечної міфології, яка віддзеркалюючи реальність, посвоєму «замінює» iї, дозволяє виділити таку тенденцію розвитку бібліотеки як персоналізація. Персоналізація проявляє себе досить різноманітно: наївною вірою у винятковість професії бібліотекаря, яка втілює інтелектуальний початок та високу мораль; фетишизацією можливостей комп'ютера та Інтернету, освоєння яких нібито дозволить вирішити більшість професійних проблем; набуттям імені як символу та бренду, що сприяє самоідентифікації бібліотеки i, таким чином, зумовлює стратегію її розвитку.

6. Актуалізація привабливих та дещо чарівних міфів, притаманних інформатизації бібліотек, багато в чому залежить від самої бібліотечної спільноти. Втілені в слові, озвучені мрії про фантастичне майбутнє бібліотечноінформаційної справи, активне позиціювання бібліотеки не тільки як інформаційного центру, а і як території позитиву, призведуть до реалізації, на перший погляд, недосяжних перспектив [13]. Підтвердженням цього є формулювання міжнародного замовлення професійної співдружності держав і народів світу як 
об'єктивної необхідності створення Штаб-квартири руху і відповідного ноосферного поселення «Бібліотехнополіс «СУДАК»» з локальною концентрацією науково-дослідних, науково-технологічних, дослідно і проектно-технологічних, бібліо-реставраційних, бібліо-художніх, бібліо-інформаційних, бібліовиробничих і маркетингових функцій [10]. Реалізація даного міжнародного i, на перший погляд, фантастичного проекту дозволить розвіяти або створити нові бібліотечно-інформаційні міфи, дозволить «сказку сделать былью» (рос.)

Репродукція міфів, як явище соціальної комунікації, не тільки відображає дійсність, але й має можливість конструювати ії. Доведеним є факт того, що під час криз та незгод творча думка сягає неймовірних висот, і те, що донедавна ми вважали утопією, зараз $є$ реальність. Тому, і сьогодні, і в майбутньому, розвиток бібліотечно-інформаційної міфології, підтримуючи в актуальному стані соціальну пам'ять та сприяючи розвитку гуманістичних, когнітивних механізмів соціального інтелекту, допомагає виконанню головних місій соціальних комунікацій.

Радикальні перетворення у функціонуванні бібліотек ВН3, пов'язані з ії інформатизацією, привели до посилення прагматичного інтересу до них зі сторони як керівного складу, так і всієї університетської спільноти. Процеси самоідентифікації бібліотеки вишу та іiї брендинг надають соціуму усвідомлення того, що сучасні інформаційні бібліотечні мережі, електронні бібліотеки, інституційні репозитарії, надання віддаленого доступу, електронних послуг та й самих креативних бібліотечних фахівців сьогодні потрібно розглядати як потужні інтелектуальні і фінансові активи закладу освіти. Сьогодні університетська спільнота, завдяки отриманню вичерпної та репрезентативної картини щодо реальних можливостей бібліотеки як гаранту надання достовірної, повної та оперативної інформації в усіх можливих форматах, сприймає бібліотечних фахівців як надійних партнерів у створенні інтелектуального потенціалу ВНЗ, регіону, держави.

\section{СПИСОК ДЖЕРЕЛ}

1. Апшай, Н. Класифікаиія бібліотек вищих навчальних закладів / Надія Апшай // Вісник. Книжскової палати. - 2004. - № 1. - с. 37-39.

2. Белл, Д. Грядущее постиндустриальное общество: Опыт сочиального прогнозирования / Пер. с англ. под ред. В.Л. Иноземиева. - М.: Academia, 1999. - 956 c.

3. Библиотечная энщиклопедия / Рос. Гос. Б-ка. - М.: Паиков дом, 2007. $-1300 c$.

4. Бриггс, Н. Наме профессиональное будущее. Британская точка зрения / Норман Бриггс // Материалы межд. конф. «Крым 2010». http://www.gpntb.ru/win/inter-events/crimea2010/disk/

5. Великий тлумачний словник украӥнської мови / Уклад. і голов. ред. В. Д. Бусел. - К.: Ірпінь: ВТФ „Перун”, 2002. - 1440 с.

6. Давидова, І. Бібліотека як складова інформаиійної інфраструктури 
держави / Ірина Давидова // Вісник книжкової палати. - 2005. - № 6. -c. 19-22.

7. Дурєєва, Т. А. Інформатизаиія бібліотечної сфери в умовах розвитку технологій інформачійного суспільства / Т. А. Дурєєва // Вісник Харківської державної академії культури: зб. наук. праџь. Вип. 24. - Х.: ХДАК, 2009. - c. 145-156.

8. Ерёменко, Т. В. Информатизация вузовских библиотек в России и США: сравнительный аналіз: монография. - М.: Пашков дом, 2003. 297 c.

9. Жуковський, В.С. Болонський процес: головні принципи входження в Європейський простір вищої школи [Текст] / В. С. Жуковський. - К.: ІВЦ ,Політехніка”, 2003. - 200 с

10.Зайдфудим, П. Х. Международный ноосферный инновационный проект: «Библиотехнополис “Судак”》 (конщептуальные подходы обоснования / П. Х. Зайдфудим // Материалы межд. конф. «Крым 2010». http://www.gpntb.ru/win/inter-events/crimea2010/disk/.

11.Ільганаєва, В. О. Бібліотечна освіта: нова парадигма розвитку / В. О. Ільганаєва. - К.: Бібл. вісн., 1996. - 253 с.

12.Колесникова, Т. А. Интеграция библиотек вузов Украины: современное состояние и перспективы развития / Т. А. Колесникова // Материалы межд. конф. «Крым 2010». - http://www.gpntb.ru/win/interevents/crimea2010/disk/105.pdf

13.Колесникова, Т. О. Бібліотечні міфи інформаційного суспільства / Т. О. Колесникова // Освіта регіону. - 2009. - №4. - с. 155-161.

14.Колесникова, Т. О. Інтеграція бібліотек ВНЗ Украӥни: сучасний стан та перспективи розвитку (за результатами соціологічного дослідження) / Т. О. Колесникова // Наук. прачі Наи. бібліотеки України ім.. В. I. Вернадського. Вип. 28. - К., 2010. - с. 209-217

15.Колесникова, Т. Сучасна бібліотека вищої школи очима студентів: за результатами соџіологічного дослідження [Текст] / Тетяна Колесникова // Вісник Книжкової палати. - 2009. - №7. - с. 26-30.

16. Мащенкко, Н. С. Інформаиійний потениіал ВНЗ у складі інформаційного суспільства / Н. С. Мащенко // Економічна психологія, етика, мораль і культура бізнесу: Вісник економіки транспорту і промисловосmi. - 2010. - № 29. - c. 444-449.

17.Півняк, Г. Національний гірничий університет: відповідність часу / Геннадій Півняк // Вища школа. - 2009. - № 2. - с. 3-14.

18.Соколова, Н. Цифровые библиотеки наших университетов: планы и реалии [Текст] / Н. Соколова, В. Рябев // Библиотека. - 1999. № 5. c. $59-62$

19.Тавальбех, А. Стратегії перетворень інформаційно-технологічного базису бібліотек / Алі Тавальбех // Проблеми фізичного виховання і спорту. - 2010. - № 3. - c. 95-97.

20.Фостер, А. Слияние библиотеки и технических служб [Электронный 
ресурс] / Андреа Фостер; Информ. Центр Ген. Консульства США в Екатеринбурге // Новости из жизни американских библиотек . 2008. - 2 апр. - Режим доступа: http://biblioru.livejournal.com. - Загл. с экрана.

21.Шрайберг, Я. Л. «Американская мечта» в библиотечном формате / Я. Л. Шрайберг // Университетская книга. - 2010. - № 5. - с. 22-27.

22. Электронное обучение. Рекомендачии руководителям библиотечных и информационных служб [Сборник статей] / под ред. Мекинг Меллинг; пер. с англ. Н. А. Багровой, К. Э. Корбут; науч. Ред. Пер. Я. Л. Шрайберг. - М.: Омега, 2006. -224 с.

23.Ярошенко Т. О. Наука-Освіта-Інформаџія: Проект «Електронна бібліотека: Центри Знань в університетах України» / Т. О. Ярошенко //Діяльність бібліотек вищих навчальних закладів у світлі модернізачії вищої освіти: Матеріали міжнар. наук.-практ. конф., м. Севастополь, 19-21 травня 2009 р. - Севастополь: Вид-во СевНТУ, 2009. c. 111-117. 


\section{2. ПЕДАГОГІЧНІ УМОВИ ВИКОРИСТАННЯ МУЛЬТИМЕДІЙНИХ ІНСТРУКЦЙ ДО ШЕВ-КАТАЛОГУ У ПІДГОТОВЦІ МАЙБУТНІХ УЧИТЕЛІВ}

Під впливом процесів глобальної інформатизації, зумовлених реаліями становлення нових цінностей і нових форм організації життя на початку XXI ст., суспільство переходить до більш широкого, гуманітарного розуміння завдань освіти. Триває процес створення нової концепції вищої школи сучасного типу, змінюються освітні цілі, які значною мірою тепер спрямовані на формування та розвиток здібностей студентів до самостійного пошуку, збирання, аналізу й використання інформації, процес навчання стає особистісно орієнтованим. Новий університет і сучасний навчальний процес вимагають нових форм та методів роботи від бібліотек вищих навчальних закладів.

Головним питанням сьогодення в системі нової освіти $€$ опанування студентами вмінь і навичок саморозвитку особистості, що значною мірою досягається шляхом впровадження інноваційних технологій, організації процесу навчання. Водночас слід пам'ятати, що будь-яку педагогічну технологію необхідно розглядати як цілісну систему у єдності компонентів і взаємозв'язків. Тому із цілої низки найскладніших проблем, 3 якими стикається процес демократизації та реформування освіти, найсерйозніша зумовлена нестачею інформаційнометодичних видань і засобів навчання.

В наш час виникає потреба в новій системі освіти, яка повинна бути безперервною та продовжуватись протягом всього періоду активного життя людини. Освіта повинна бути загальнодоступною і не залежати від місця знаходження суб'єкта. На сучасному етапі в українській освітній системі відбувається модернізація, головними рисами якої є: зміна типу педагогічного процесу від репродуктивного до суб'єктивно-орієнтованого (перехід до принципів відкритої освіти, залучення нових підходів, суб'єктного і компетентнісного); використання інформаційно-комунікаційних технологій; використання електронного навчання як форми та процесу; використання технологій відкритої освіти. Термін «відкрита освіта» має соціальний аспект, тобто визначає освіту як таку, що притаманна відкритому суспільству. Для відкритого суспільства характерні певні ключові особливості: мета - розвиток суб'єктності та індивідуальності людини при активній іiі самореалізації; позиціонування людини, як суб'єкта в ситуації варіативних освітніх можливостей, в яких він повинен зробити відповідальний вибір; необмежений просторовими та часовими рамками; різноманіття використовуваних способів пізнання життя, що забезпечує цілісність сприйняття дійсності та багатогранність досвіду людини [5].

Така позиція вимагає від сучасної освіти реформаційних кроків, щодо оновлення іiі змісту та застосування нових педагогічних підходів, впровадження інформаційних і комунікаційних технологій, що модернізують навчальний процес.

Реформування системи роботи бібліотек вищих навчальних закладів тісно пов'язане $з$ процесами їх інформатизації та комп'ютеризації. Концептуальні питання інформатизації бібліотек останнім часом активно обговорюються у світо- 
вому співтоваристві. При цьому основна увага приділяється пошуку рішень, що якнайбільше враховують культурно-історичні реалії загальнонаціонального масштабу та специфіку конкретної галузі суспільної діяльності.

Модернізація української освіти в цілому потребує від кожного вищого навчального закладу перебудови всіх його сфер діяльності: освітньої, науководослідної, адміністративної тощо. Як фундаментальна частина вищого навчального закладу, його бібліотека не може залишатись осторонь, вона повинна відповідати збільшеним за обсягом і якісно новим за характером, вимогам вищої школи, особливо вимогам забезпечення інформацією, організацією обслуговування всіх учасників навчального процесу.

Широке поширення нових інформаційних технологій сформувало необхідні передумови для створення електронних бібліотек, як засобів накопичення й поширення інформаційних і методичних ресурсів. Завдяки мережевій інфраструктурі, що інтенсивно розвивається, ці ресурси стають потенційно доступними будь-якому користувачеві мережі і надають необмежені перспективи для розширення навчальної аудиторії.

Технології отримання знань набувають на сьогоднішньому етапі розвитку освіти велике значення. Ці технології отримали назву «електронного навчання». В освітніх колах для визначення схожих понять використовують також терміни «відкрита освіта», «дистанційне навчання», «Інтернет - навчання» тощо.

В умовах збільшення обсягу часу для самостійної роботи і зміни ії характеру в загальному навчальну процесі, зростає необхідність у появі освітнього центру, який зміг би забезпечувати підтримку самостійної навчальної діяльності студентів у електронному середовищі. Таким центром може стати і стає бібліотека вищого навчального закладу. Це означає, що необхідно досконально переглянути систему роботи бібліотеки університету й підняти на новий рівень усі їі елементи, методологічно обгрунтувавши напрямки й суть змін.

В зв'язку з тим, що у вищому навчальному закладі відбувається процес впровадження електронного навчання, у бібліотек університетів 3'являються нові задачі. Електронне навчання дозволяє реалізувати принцип: «Вивчати те, що необхідно в будь-який (зручний для того хто навчається) час, в будь-якому (зручному для того хто навчається) місці» [6].

Із впровадженням електронного навчання бібліотека вищого навчального закладу повинна не тільки зберегти якість і повноту традиційних функцій та напрямків діяльності, але запропонувати студентам і викладачам комплекс нових сервісів і послуг для якісного інформаційного забезпечення і підтримки електронного навчання. Ефективність електронного навчання забезпечується постійним і більшою мірою - дистанційним доступом студентів до електронних навчально-методичним комплексів; супроводом довідково-онлайнового обслуговування; консалтингового супроводу у частині використання інформаційноосвітнього й навчального середовища.

При тому, що в сучасному освітньому процесі в загальній сумі навчальних заходів велику частину займає самостійна робота студентів, роль бібліотеки полягає не лише у забезпеченні доступу до масиву традиційних навчальних, нау- 
кових та інформаційних ресурсів, але й в організації постійно доступного віртуального інформаційно-бібліотечного простору, забезпеченні місцями роботи у електронних та комп'ютерних залах, а отже, і комплексом консультативної та довідкової діяльності в очній та електронній формі. Для розвитку у студентів навичок користуватися інформаційною освітньою системою, бібліотека може організувати курси з використання електронних ресурсів, пошукових засобів в інформаційно-освітній системі вищого навчального закладу.

Із збільшенням частки самостійної роботи в навчальному процесі, бібліотечний співробітник, стає одним із найдоступніших консультантів для студента як в реальному, такі в віртуальному середовищі. Оскільки в бібліотеках уже почався процес впровадження віртуального довідкового обслуговування, співробітники бібліотеки можуть не лише виконувати задачі електронного інформаційного сервісу, але частково і роль тьютера. Як при очному консультуванні, зміст консультації може містити питання довідкового, техніко-технологічного, інформаційного, методичного, програмного характеру. Тому на сучасному етапі у розвитку бібліотек все більш важливу роль відіграє освітня та педагогічна функція бібліотеки університету. Так одним з ключових напрямків розвитку педагогічних функцій бібліотеки $є$ формування інформаційної культури студентів.

Проблема готовності користувачів до діяльності в умовах застосування інформаційно-комунікаційних технологій $є$ багатоаспектною, та охоплює велике коло питань. Інформаційні компетенції $\epsilon$ ключовим чинником в освітньому процесі. Вони $\epsilon$ першим кроком на шляху до досягнення освітніх цілей. Студенти повинні розвивати свої інформаційні компетенції як в роки навчання так по закінченні вишу, і тут бібліотекарі, як члени освітнього співтовариства університету і фахівці по роботі з інформацією, відіграють або повинні навчитися відігравати ключову роль у забезпеченні інформаційної грамотності [4].

Дистанційне і електронне навчання полегшує вирішення завдань групового навчання інформаційній грамотності. Це особливо важливо при обмеженій кількості бібліотекарів і фахівців у галузі інформаційних технологій. Фахівці такого рівня повинні освоїти нові форми освіти і методики викладання з використанням мереж, особливо Інтернету - як віртуального класу замість традиційної класної кімнати. Бібліотекарі можуть спілкуватися з користувачами інтерактивно. Користувачі можуть виконати дослідницьку роботу або завдання вдома, на роботі або в будь-якому іншому місці, де $\epsilon$ доступ до комп'ютера і телекомунікаційних мереж. У свою чергу бібліотекарі можуть вести інструктаж з будьякого місця, де $\epsilon$ комп'ютер.

Таким чином, для підтримки електронного навчання бібліотека вищого навчального закладу реалізує комплекс функцій, ключовими з яких $є$ інформаційна, освітня та педагогічна.

Використання засобів мультимедіа з метою повторення, узагальнення та систематизації знань не тільки допомагає створити конкретне, наочно-образне уявлення про предмет, явище чи подію, які вивчаються, але й доповнити відоме новими даними. Відбувається не лише процес пізнання, відтворення та уточнення вже відомого, але й поглиблення знань. Під час роботи 3 навчальною 
програмою важливо зосередити увагу студентів на найбільш складну для засвоєння частину, активізувати самостійну пошукову діяльність студентів.

Оскільки у педагогічному університеті проведення навчальних курсів 3 інформаційної грамотності не включено до навчальних планів, а консультації 3 використання інформаційних ресурсів бібліотеки надаються лише на прохання куратора групи, було прийнято рішення та розроблено на WEB-сторінці бібліотеки спеціальний розділ «Питання-Відповіді», де кожен читач у віртуальному просторі може отримати консультаційну допомогу з будь-якого питання стосовно використання фондів та інформаційних ресурсів бібліотеки.

3 часом стало зрозумілим, що читачам необхідні також консультації по роботі з базами даних електронного каталогу, особливо для складних видів пошуку, які дозволяють підвищити релевантність знайдених документів. Це наштовхнуло на створення мультимедійних онлайн інструкцій 3 методики використання WEB-каталогу НБ НПУ імені М. П. Драгоманова.

Для кожного з видів пошуку, що пропонуються в системі, було підготовлено окремі мультимедійні інструкції. В них розглянуто всі аспекти проведення пошуку: Стандартний, Розширений, Професійний, За словниками, УДКнавігатором, ГРНТИ-навігатором, Тематичним навігатором.

Інструкція «Стандартний пошук» розглядає аспекти проведення пошуку за одним з вибраних пошукових полів: ключові слова, автор, назва, рік видання, i також кафедра. Пошукове поле кафедра було створено на прохання Інституту дистанційного навчання, який у рамках проекту «Електронна педагогіка» організовує підготовку кафедрами підручників на електронних носіях. Відповідно за даними поля кафедра можна знайти, яка з кафедр брала участь у підготовці даного ресурсу, яка кількість електронних документів підготовлена кафедрою, тобто студент має можливість скористатись саме тими матеріалами у навчальному курсі, які рекомендують викладачі кафедри. Дане поле $є$ активним лише для бази даних «Каталог повнотекстових документів». В інструкції розглядається також аспект, що висвітлює результат пошуку за ранжируванням, пошук за всіма базами даних електронного каталогу, пошук документів схожих за тематикою, ключовими словами, авторами, предметними рубриками, індексами УДК тощо. Висвітлено аспект гіпертекстових посилань на повні тексти документів. Відео-інструкція стандартного пошуку умовно поділена на дві частини: перша - це методика проведення самого пошуку, друга розглядає можливості системи Web-каталогу в плані висвітлення результатів пошуку та гіпертекстових посилань.

У інструкції 3 «Розширеного пошуку» представлено методику створення пошукового запиту з використанням скорочення закінчення термінів та використанням одночасного поєднання декількох пошукових полів за допомогою логік. Це дозволяє вивести, наприклад, за логікою «I» перелік джерел, які одночасно мають обидва (або більше) пошукових компонентів.

Інструкція 3 «Професійного пошуку» розглядає методику створення алгоритму пошукового виразу з використанням всіх полів системи, об'єднання їх із використанням логічних індикаторів АБО, I, НІ. 
Методика за якою читач може скористатися термінами із словників створених за допомогою системи IRBIS64, подається у відео інструкції «Пошук за словниками».

У відеоінструкціях 3 пошуку «За рубрикатором УДК» та «ГРНТИнавігатором», показано методику використання рубрикаторів, пошук за ключовими словари рубрик, використання горизонтальних та вертикальних шляхів пошуку за допомогою індексів класифікаторів.

Кожна з інструкцій спрямована на допомогу в освоєнні читачем різноманітних видів пошуку, що допомагає проведенню грамотного складання пошукового запиту, i, як результат, отримати потрібну інформацію. Розміщенні відео інструкції на сторінці Web-каталогу бібліотеки.

Дистанційні та електронні засоби навчання мають великий креативний потенціал, що дозволяє впроваджувати у бібліотечну практику нові форми творчості, різноманітити методи роботи і навчання.

В діяльності бібліотеки з'явились процеси, пов'язані з забезпеченням електронного навчання, такі як: формування електронних фондів, організація депозитаріїв, формування елекронного довідково-бібіографічного апарату, електронне обслуговування в різних формах, консультаційні послуги технологічного і методологічного характеру.

Нова якість освіти потребує від бібліотеки вищого навчального закладу тісної інтеграції в процесі електронного навчання від створення контента до часткового створення навчальних сервісів. Застосування систем менеджмента якості освіти, дозволяє чітко прослідкувати, пов'язати та стандартизувати зв'язки між бібліотекою та іншими структурними одиницями університету у таких значущих процесах як, наприклад, «Створення електронного підручника», що $\epsilon$ одним 3 підходів до інтеграції бібліотеки в інформаційно-освітній простір вищого навчального закладу.

Інформаційне освітнє середовище включає систему апаратних засобів, програмне, забезпечення, фахівців і користувачів, бази даних, що реалізовують інформаційні процеси. Різні дослідження і практичні роботи із створення інформаційного освітнього середовища наповнюють поняття «інформаційне середовище» конкретним змістом. Однією з основних властивостей інформаційного середовища $є$ іiї відкритість.

Електронне навчання є одним з ефективних методів отримання необхідних компетенцій не лише для студентів, але і для персоналу відділів обслуговування бібліотек вищих навчальних закладів, оскільки занурює співробітників в таке ж середовище, в якому навчається студент.

Таким чином, в умовах застосування технологій електронного навчання бібліотека університету повинна стати і стає його центром, що відповідає сучасним потребам нового типу навчального процесу.

Навчання користувачів, невід'ємна функція довідково-бібліографічного обслуговування, на сучасному етапі - етапі нових і постійно розвиваючих інформаційних технологій вона тільки збільшується. Від простих баз даних на локальних носіях до Інтернету, 3 його тотальним проникненням в сферу 
інформаційного обслуговування в цілому і пошуком інформації зокрема: це потребує розгорнутих знань комп'ютерних технологій не тільки від спеціалістівбібліографів, але й від читачів бібліотек. Дуже часто вони потребують навчання новим технологіям, можливостям використання нових послуг, навичкам проведення глибинних пошуків інформації та оцінки джерел інформації.

В умовах використання інформаційних технологій вміння вести самостійний кваліфікований інформаційний пошук, навички діалогу з інформаційнопошуковими системами різного рівня і якості, майбутній фахівець повинен одержати, у першу чергу, у реальних умовах бібліотеки ВНЗ.

Одним 3 актуальних напрямків інформаційного забезпечення діяльності майбутнього фахівця $є$ формування його інформаційної компетентності в умовах використання інформаційно-бібліотечних технологій.

Бібліотека, у якій зосереджені колосальні обсяги інформації та створенні необхідні умови для роботи з нею, може надати істотну допомогу у формуванні інформаційно-професійної компетентності майбутніх фахівців. У реальних умовах бібліотека сучасного вищого навчального закладу має арсенал засобів для розробки системи взаємодії студентів як із традиційними бібліографічними довідково-бібліографічними апаратами так і $з$ електронними інформаційнопошуковими системами в тому числі представленими у глобальній мережі.

Взаємодія студентів з безліччю ресурсів (книгами, журналами, газетами, мультимедіа, телебаченням, Інтернет, суспільством, людьми) мотивує студентів освоїти навички орієнтуватися у потоках інформації. Де і як знайти інформацію, яка щонайкраще розкриває дану тему, як зафіксувати й інтерпретувати інформацію, як її оцінити, як взаємодіяти 3 колегами по обробці інформації, як організовані інформаційні зв'язки і доступ до інформації, як інформація засвоюється в процесі навчання, ось питання які студенти прагнуть вирішити. Заохочення студентів у самостійних спробах направляти інформаційні пошуки зміцнює почуття впевненості i самоуправління навчанням, a досягнення інформаційних цілей сприяє ефективному закріпленню інформаційноскладальних і інформаційно-обробних шаблонів. Такий процес навчання співзвучний із реальним життям, в якому суб'єкт націлюється на постійне полювання за інформацією, на ії інтерпретацію і використання, стаючи самокерованим студентом. Накопичений досвід роботи 3 інформаційними ресурсами дозволяє студентові сформувати репертуар навичок і основ знань, що можуть бути використані в ситуаціях навчання в майбутньому.

Важлива роль у реалізації процесу ресурсно-орієнтованого навчання надається бібліотекарям, що разом з викладачами стають мотиваторами навчальної діяльності, яка забезпечує початковий тематичний поштовх, що направляє студента не тільки в його пошуках інформації, але й у становленні творчої особистості - людини здатної вирішувати проблеми. Студенти можуть починати дослідження поставлених перед ними проблем без усвідомлення того, які навички їм необхідні і які вони мають, і того, як цим навичкам можна навчитися. Вони можуть не усвідомлювати, що бібліотекарі ведуть їх до інформації і до ідей, що стосуються їх потреб, але бібліотекарі як фахівці із навігації в інформаційних 
ресурсах повинні чітко усвідомлювати свої функції стосовно підтримки інформаційної компетентності студента.

Освіта і якість освіти, ії доступність та відповідність потребам конкретної особистості у вирішальному ступені визначають стан інтелектуального потенціалу сучасного суспільства.

\section{СПИСОК ДЖЕРЕЛ}

1. Базаева А. П. Формирование информачионно-профессиональной компетентности будущего учителя средствами информационных технологий библиотеки : Дис. . канд. пед. наук : 13.00.08 / Базаева А. П. Челябинск, 2005. - 192 c.

2. Галеева И. С. Интернет как инструмент библиографического поиска : практическое пособие / И. С. Галеева ; науч. ред. М. И. Вершинин. Санкт-Петербург : Профессия, 2007. - 248 с.

3. Журавлева О.Б. Управление интернет-обучением в высшей школе : учебное пособие / О. Б. Журавлева, Б. И. Крук, Е. Г. Соломина. - М. : Горячая линия-Телеком, 2007. - 224 С. : ил.

4. Лау Хесус Руководство по информационной грамотности для образования на протяжении всей жизни / русский перевод Guidelines on Information Literacy for Lifelong Learning - Последняя редакиия: 30 июля 2006 г., Александр Федоров (научное редактирование перевода), 2007, Татьяна Сорокина / Начиональный фонд подготовки кадров (перевод), 2006, Издатель МОО ВПП ЮНЕСКО «Информаиия для всех» // [электронный ресурс] http://www.ifap.ru

5. Орлов П. І. Інформаційні системи і технології в управлінні, освіті, бібліотечній справі : науково-практичний посібник / П.І. Орлов, О. М. Луганський. - Донеиьк : Альфа-прес, 2004. - 292 с.

6. Самообразование: возможности, ресурсы и технологии: научное издание / М-во образования и науки РФ, Федеральный ин-т развития образования (ФИРО); сост. Ю. И. Лобанов. - М., 2008. - 64 с. ; 20 см. - (Новые информационные технологии в образовании : аналитические обзоры по основным направлениям развития высшего образования : обзорная информация; вып. 11.)

7. Соколова Ю. В. Вузовская библиотека как иеентр поддержки электронного обучения : диссертация кандидата педагогических наук : 05.25.03 / Соколова Ю. В.; [Место защиты: Моск. гос. ун-т культуры и искусств].- Москва, 2007.- 170 с.: ил. 


\section{3. МЕДІАОСВІТА ЯК РОЗУМІННЯ СВІТУ МЕДІА}

Світ медіа $€$ таким, яким є. Дослідження свідчать, що роль засобів масової комунікації у житті окремої людини і суспільства в цілому зростає [5, с. 240]. Життя сучасної людини неможливо уявити поза впливом медіа. Раніше, ніж дитина відкриє і прочитає свою першу книжку для неї відкриє світ телебачення, i від того, які думки і почуття пробуджують вони в дитині, залежить процес формування внутрішнього світу особистості [6, с. 223]. Ряд досліджень вітчизняних та зарубіжних науковців присвячено проблемі негативного впливу медіа на аудиторію, особливо на дітей та підлітків, які ще не здатні критично мислити і аналізувати інформацію, повідомлення, відеоряд сюжету чи художнього фільму.

Цій проблемі присвячені деякі роботи та дослідження Потятиника Б., Різуна В., Бабіч І., Онкович Г., Баришполець О., Федорова О., Кириллової Н., Бондаренко Е., Журіна А., Брайанта Д., Томпсон С., Морган М, Бандури А. Здебільшого в них розглядається негативний вплив медіа, який вони спричиняють на аудиторію.

В розділіі аналізується вплив медіа на аудиторію та розглядається місце медіаосвіти у системі соціалізації особистості. Також увага приділена таким поняттям, як «суспільна дійсность» та «медійна реальність».

Мета цього маленького дослідження - проаналізувати вплив медіа, спробувати дослідити, чи справді він такий поганий та як $з$ цим впливом можна боротися (і чи потрібно взагалі це робити).

Існує дві найбільш поширені теорії щодо впливу медіа на аудиторію, протилежні за своїм змістом. Теорія так званого «прямого впливу», яка стверджує, що ЗМІ впливають на аудиторію, посилюючи вже існуючі шаблони поведінки, ніж змінюючи їх, і теорія «обмеженого впливу», яка в свою чергу стверджує, що вплив медіа не $\epsilon$ абсолютним, він $\epsilon$ опосередкованим. Звісно, $\epsilon$ ще декілька теорій, але їх ми свідомо не будемо розглядати, адже дослідники 3 медіаосвіти приділили достатньо площі цим теоріям (див. матеріали російського вченого О. В. Федорова).

Потятиник Б. стверджує, що психіка людини незалежно від іiї освітнього рівня беззахисна перед тиском з боку медіа, і для будь-якої людини можна підібрати ефективні засоби маніпуляції. Особливо шкідливий вплив спричиняють медіа на молодь. Діапазон цього впливу великий: від пропаганди нездорового харчування до екранного насильства [8, с. 18]. На підтвердження цього можна навести твердження Д. Боуї, майже 40 років тому, а саме у 1972 році, він сказав: «Ми створили тип дитини, яка настільки перебуває під впливом ЗМІ, що, коли вона досягає 12 річного віку, батьки повністю втрачають контроль над нею» [3, с. 21].

Активний телеглядач бачить світ навколо себе набагато більше схожий на його образ на екрані телевізора. Некритичне ставлення до реальності не дозволяє людям розрізняти реальне від ідеального (наприклад, невміння розрізняти виборчі заклики про реальні соціальні гарантії від передвиборчого блефу). Крім того, помилки однієї людини, а точніше медіаперсони, які розтиражовано за допомогою засобів масової комунікації можуть стати помилками мільйонів людей. 
Дії героя улюбленого фільму стають для дитини еталоном поведінки [5, с. 242]. Наприклад, маленьким дітям важко зрозуміти, що людина не може літати як Супермен, Бетмен чи інші супергерої, що після падіння чи зіткнення важко оговтатися, що неможливо керувати автомобілем, дивлячись назад чи на людину, яка сидить поруч, як це часто буває в художніх фільмах. Це є художній фільм, дії відбуваються на знімальному майданчику, всім дійством керує сценарист, режисер та продюсер, і часто так трапляється, що з реальністю фільм має мало спільного.

Але $є$ позитивні моменти, так само як і дитячі казки, які пояснюють дітям де добро і де зло, що таке погано і що таке добре, як треба себе поводити, що потрібно робити в певних ситуаціях, дитячі фільми та програми можуть нести позитивний зміст. Здебільшого відношення «діти і підлітки - ЗМІ» зводяться до програмування моделей поведінки і формування відношення до життя. Встановлено, що під час перегляду мультиплікаційних фільмів сцени насилля вторгаються у дитячу свідомість у 10 разів більше ніж у разі акторського виконання [6, с. 255]. Дитячі освітні і розважальні програми (в яких нема місці сценам насилля та жорстокості) сприяють інтелектуальному розвитку дитини, розвивають іï уяву, навички вирішення проблем, сприяють соціалізації. В такому разі перегляд передачі виявляється корисним для дитини і не завдасть їй шкоди.

Так, телепередачі для дітей, що є чемними і доброзичливими, формують позитивні образи хлопчиків і дівчаток. Діти емоційно сприймають передачі, не вдаються до критичного аналізу їх змісту і на довірі до телебачення переймають тип заданої поведінки [9, с. 12].

Теодор Адорно і Еріх Фромм у своїх працях аналізували, що люди прагнуть зняти відчуття невдоволеності через сцени насилля та жорстокості на телевізійному екрані (таким чином реалізується потреба марення-мрії). Крім того, неофрейдист Е.Фромм висловлював думку, що потреба у насиллі замаскована і приховано живе у свідомості людини, вимагаючи насилля екранного, книжного, газетного.

Власне саме для захисту людей від медіа, які були створені аби допомагати і 3'являються ідеї медіаосвіти. Розглянемо декілька тлумачень цього терміну. На думку дослідника з Санкт-Петербургу Корконосекна Г. медіаосвіта - являє собою процес від прищеплення первинних навичок використання медіа, тобто читання, слухання до розвитку культури самостійного випуску видань, теле- і радіопрограм [7, с. 82].

3 іншого боку Потятиник Б. стверджує, що медіаосвіта - це знання про медіа та про їх маніпулятивний та патогенний вплив. Наприклад, у Великій Британії при медіавихованні акцент робиться на використанні медіапродукції та індивідуальний захист від її негативного впливу на особистість.

Одним з чинників, який спричиняє багато проблем є реклама, яка весь час пропонує нові-модні-кращі товари, пропонує певну поведінку та стиль життя. Завдяки їй, наприклад, поширюються недосяжні для багатьох людей стандарти зовнішності, що вступають в конфлікт 3 реальністю. В одному 3 інтерв'ю А. К. Троїцький, російський шоумен, висловлював такі думки про глянцеві видання: «Я вважаю, що глянцеві видання - це категорично немодно, як би вони 
себе не називали модними, супермодними, мегамодними. По-друге, вони (глянцеві видання) сприяють зомбуванню, оглупленню та отупленню. Вважаю, що видання в яких пишеться про речі, які не мають жодного відношення до реального життя, у яких демонструють одяг, автомобілі, усілякі предмети, які є доступними лише для $1 \%$ населення, є шкідливими» [10, с. 350-351].

Окрім того медіа постійно виробляють погані новини (наприклад, пташиний та свинячий грип, пожежа у заповіднику Асканія-Нова, вбивства, скандали тощо). Вайшенберг 3. висуває припущення, що ЗМІ творять власну реальність, яка $є$ корисною з погляду орієнтації в реальності [4, с. 21].

Дуже цікавими є результати дослідження, які проводив професор Саутгемптонського університету соціолог Роджер Інгрєм на прохання уряду Британії про джерела і причини футбольного хуліганства. Його вирок був такий, якщо перестати друкувати та розповсюджувати газети, наприклад, з понеділка, то й футбольне хуліганство зникне з того ж понеділка. Адже на передодні матчів з'являються статті про те, що без бійок і нищення вітрин магазинів і фасадів будинків не обійдеться, що вболівальники команди «У» прийдуть зі зброєю, а вболівальники команди «Х» минулого разу розтрощили цілу вулицю $[11$, с. 95]. До речі, у вболівальників футболу дослідники відмічають більшу схильність до насильства, ніж у вболівальників неагресивних видів спорту. Загально відомо, що спортивні фанати ставляться до свої улюблених команд та спортсменів як до улюблених героїв, а до команди-суперника ставлення наче до злодіїв.

Проблема фабрикації і містифікацій подій, яка також притаманна 3МI, бере свій початок ще з часів літописців. Коли, Нестор, наприклад, описував князя Олега як винахідника скейт-серфінгу, опис кораблів до яких прибили колеса аби перейти пустелю (похід Олега на Константинополь) [2, с. 14].

Далі ще цікавіше, наприклад, війна як reality show. Це дуже добре було показано у художньому фільмі «Wag The Dog», у якому аби відвернути увагу громадськості і ЗМІ від скандалу до якого причетний Президент країни, спеціально вигадують війну в Албанії. Або політ американців на Місяць, коли головним стає змагання за право бути першим. Американці навіть залучили відомого кінорежисера Стенлі Кубрика до зйомок висадки американських астронавтів на Місяць на той випадок, якщо все ж таки Радянський союз їх випередить.

Умберто Еко ввів спеціальний термін «гіперреальність» саме для позначення домінування віртуального над реальним. Звісно, для людей, обізнаних 3 «кухнею» 3MI, достатньо легко вберегтися від впливу медіа. Більшість так званих публічних осіб стверджують, що вони взагалі не дивляться телевізор і не читають газети та журнали, деякі стверджують, що в їхніх помешканнях взагалі немає телевізору.

Зараз про новини можна дізнатися з всесвітньої мережі Інтернет, також там можна знайти фільми і музику, продивитися безліч записів на YouTube, прочитати сторінки-блоги тощо. Люди, які регулярно користуються Інтернетом, не тільки значно менше дивляться телевізор, вони більше займаються спортом, читають книжки і частіше спілкуються з друзями [8, с. 35]. 
Звісно, медіаосвіта необхідна, але потрібно дійти єдиної думки щодо тлумачення цього терміну та програми курсів. У різних країнах по-різному ставляться до цього, деякі діти вивчають аспекти функціонування медіа ще у школі, хтось знайомиться 3 цим у коледжі, десь можна долучитись до курсів у будьякий час, а в деяких країнах люди взагалі позбавлені такої можливості.

У психології сприйняття $\epsilon$ теза про те, що «по суті, жоден 3 нас не бачить реальності; ми лише інтерпретуємо те, що бачимо, і називаємо це реальністю». Медійна реальність і суспільна дійсність завжди будуть відрізнятись одна від одної. Тому що все залежить від людини. Це можна проілюструвати на прикладі рекламного тексту одного відомого безалкогольного напою «...хтось бачить стакан наполовину порожнім, а хтось наполовину повним ...». Це стосується як глядачів, слухачів і читачів, так і редакторів та журналістів.

Боротися зі 3МI неможливо, потрібно навчитися їх використовувати. Таку ситуацію дуже добре ілюструє вислів: «якщо ваша дитина живе на березі океану, краще навчити ії плавати, ніж будувати паркан навколо океану».

Поки дитина маленька, поки ії мислення подібне до міфологічного, батьки можуть контролювати зміст мультфільмів та фільмів, які дозволяють дивитися їй. Коли з'явились на телебаченні покемони, всі були шоковані, що таке можливо, але трансляцію так і не заборонили. Звісно, легше придбати дешеві мультфільми, аніж платити гроші за якісні фільми чи знімати самим. Те ж саме стосується і підлітків, режисери і продюсери мають на меті одне - повернути всі гроші, які були витраченні на виробництво фільму, фільм окупається завдяки зірковому складу акторів і спеціальним ефектам. Дітям не зрозуміло, що повторювати дії, які вони бачили на екрані, не можна, бо це може мати фатальні наслідки. Якщо відійти від дітей і звернутися увагу на дорослих, багатьом 3 них так само не зрозуміло, що ведучій або актриса добре виглядають на екрані завдяки освітленню та гриму, крім того з ними щодня працює команда тренерів, дієтологів, стилістів. Адже чим реалістичніший медіаобраз, тим сильніше він впливає на глядача, таких висновків дійшов Г. Комсток [3, с. 96]. Теорія екземпліфікації (наведення прикладів) Д. Зіллмана доводить, що світ прикладів та взірців з'явився аби впливати на сприйняття аудиторії, осмислення і судження щодо явищ та проблем так званого реального світу.

Дуже цікавим видався проект Іоланти Бабіч, вона пропонувала школярам вивчати деякі теми з біології за допомогою рекламних звернень. Наприклад, можна взяти рекламу сирку «President» та йогурту «Растишка» чи «Activia». Дітям ставили такі питання для аналізу: що за корисні бактерії містяться у йогурті? Чи корисний сирок, який проходить спеціальну обробку для того, аби довго зберігатися? Таким чином, крім знань 3 біології діти також вчаться аналізувати інформацію, виділяти головне в повідомленні, розуміти спрямованість інформаційного потоку, шукати прихований зміст повідомлення та розуміти цілі повідомлення [1, с. 33-34]. В подальшому вони будуть знаходитись під впливом реклами набагато менше, адже, як правило, діти в магазині просять батьків купити їм ту саму цукерку, рекламу якої вони бачили під час перегляду свого улюбленого мультфільму чи програми. 
Одним з позитивних моментів у діяльності медіа $є$ привернення уваги аудиторії або іï частини до певних проблем. Наприклад, під час рекламної компанії Kellog для товару All-Bran, яка проводилась у 1980 році, використовували інформацію Національного інституту проблем раку аби підкреслити користь від їжі, багатої на волокна і з малим вмістом жирів, у результаті - люди стали більше вживати нежирної їжі. Аналогічна ситуація з інформацією про автомобільні катастрофи, вона змушує людей, які мають авто, звертати увагу на використання ременів безпеки під час їзди.

Зараз неможливо уявити життя без медіа. Телебачення, радіо, газети, журнали всі вони намагаються донести певну інформацію до своєї аудиторії. А від змісту цієї інформації залежить і ставлення людей до оточення. Отже, потрібно навчитися розуміти медіа: чому саме так подається інформація, чому саме така інформація (адже в світі весь час щось відбувається), чому саме ця стаття займає першу шпальту, тощо. Звісно, знання та розуміння медіа не зашкодять нікому. Потрібно тільки вирішити, як саме має відбуватися процес медіаосвіти.

\section{СПИСОК ДЖЕРЕЛ}

1. Бабіч І. Використання рекламних звернень у навчанні біології / Іоланта Бабіч // Біологія і хімія в школі. - 2004 - №5 - c. 33-34

2. Баймухаметов С. От Олега до Ричарда: два сюжета о том как создаются мифы / С. Баймухаметов // История. - 2002 - №45 - с. 14-16

3. Брайант Д. Основы воздействия СМИ /Д. Брайант, С. Томпсон; пер с англ. - М.: ИД «Вильямс», 2004. - 432 с. ISBN 5-8459-0597-4

4. Вайшенберг 3. Новина журналістика: навчальний посібник [текст] / 3. Вайтенберг: под ред. В. Ф. Іванова. - К.: Академія української преси, Центр вільної преси, 2004. - 260 с. ISBN 966-7181-73-1

5. Журин А. Параллельная школа СМИ: искажение картины мира / А. Журин // Народное образование. - 2004 - №1 - с. 240-247

6. Мифы буржуазной журналистики / [под. ред Я. Н. Засурского]. М., Мысль, 1979. - 288 с.

7. Корконосенко Г. С. Преподаем журналистику. Профессиональное и массовое образование [текст] : учебное пособие / С. Г. Кирконосенко. - Спб.: Изд-во Михайлова В. А., 2004 - 238 с. ISBN 5-806-0219-4

8. Потятиник Б. Медіа: ключі до розуміння [текст] / Б. Потятиник. Львів: ПIАC, 2004 - 312 с. (Медіакритика) ISBN 966-7651-18-5

9. Різун В. В. Розвиток науки про масову комунікаиію в Інституті журналістики Київського начіонального університету імені Тараса Шевченка / В. В. Різун // Сочіальні комунікачії сучасного світу: науковотеоретичний збірник / Гол. ред. О. М. Холод. - 2009. - с. 8-13 10. Смирнова А. Кухня школы злословия / А. Смирнова, Т. Толстая. - М., Издво «Кухня», 2004. -358 c. ISBN 5-98793-005-7

10. Чепоров Э. А. Как делаются сенсации / Эдгар Анатольевич Чепоров. М., «Советская Россия», 1983. - 112c. - (По ту сторону). 


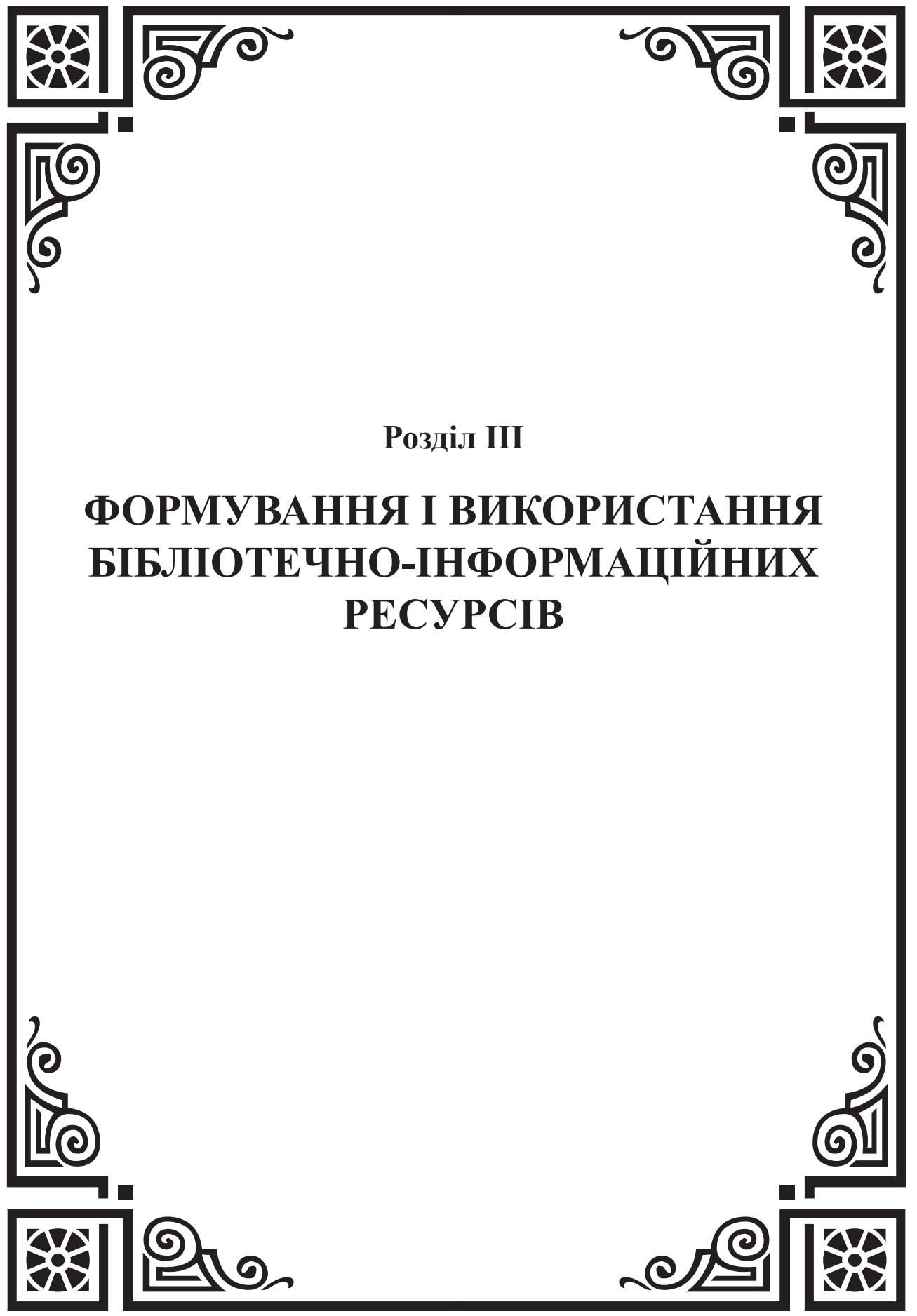




\section{1. КЛАСТЕР ЯК НОВА РЕГІОНАЛЬНА МОДЕЛЬ ІНТЕГРАЦЇ̈ БІБ- ЛІОТЕК ВНЗ: КОНЦЕПТУАЛЬНІ ХАРАКТЕРИСТИКИ ТА УМОВИ РЕ- АЛІЗАЦІї}

Актуальність даної теми визвана фактом того, що глобалізація освіти і науки породжує підвищення вимог до оперативності та якості їх інформаційного забезпечення. Це характеризується як посиленням потреб доступу спільноти закладів вищої освіти до світових інформаційних ресурсів, так і необхідністю оперативного інтегрування результатів вітчизняних досліджень до світового інформаційного простору, до кола уваги міжнародної освітньо-наукового співтовариства.

Сучасні інтеграційні процеси, тенденції до укрупнення та об'єднання регіональних вищих навчальних закладів в Україні, Росії та Білорусії мають за мету продуктивну реалізацію і розвиток конкурентних переваг університетів на ринку освітніх і науково-технічних послуг; досягнення/закріплення якісних характеристик підготовки фахівців, затребуваних господарчою практикою; підтримку і розвиток наукових шкіл, повноцінну реалізацію результатів їх діяльності на вітчизняному та світовому ринках науково-технічної продукції. Саме ці цільові вектори роблять надзвичайно актуальним завдання формування ресурсної бази інформаційного забезпечення освіти в умовах регіону, а бібліотеки ВНЗ розглядаються як особливо важлива частина освітнього, наукового та культурного регіонального простору. Це примушує бібліотеки вишів активізувати пошуки свого місця в інформаційній інфраструктурі суспільства. Тому питання кооперативної взаємодії, співпраці і інтеграції в єдину систему є провідними напрямками сучасного розвитку вузівських бібліотек.

Можливості для кооперованого використання бібліотечно-інформаційних ресурсів на основі традиційних технологій, наприклад, на рівні регіону, обмежені економічними факторами, тому в сучасних умовах найбільш раціональним для бібліотек ВНЗ є співробітництво в області інформаційних технологій як у напрямку створення ресурсів, так і їх ефективного використання. Така інтеграція відбувається тільки за умов узгодження інформаційних процесів і комунікацій між ними за рахунок забезпечення інформаційно-комунікаційної взаємодії бібліотечних систем. Основою такої взаємодії є єдина нормативно-правова та організаційно-технологічна політика, яка має базуватись на загальних інтерпретаціях обставин комунікації бібліотек та на засадах взаємовпливу, взаємозалежності, планування та підпорядкування.

Питання розвитку інтеграційних процесів бібліотек $є$ постійною темою досліджень вітчизняних та закордонних бібліотекознавців. Проблемам удосконалення процесів інтеграції бібліотечно-інформаційних інститутів присвячені праці О. В. Баркової, Т. Вилегжаніної, В. Горового, І. О. Давидової, В. О. Ільганаєвої, М. С. Карташова, Л. Й. Костенка, М. Сороки, А. О. Чекмарьова, Чжао Лін, Г.В.Шемаєвої, Я. Л. Шрайберга. В їх творах підкреслюється теза про те, що міжбібліотечна комунікація повинна бути інтегрованою сукупністю всіх взаємодій бібліотек, охоплюючи організаційні, техніко-технологічні і управлінські процеси. 
Загальні та регіональні стратегії, методи взаємодії та співробітництва бібліотек, різні аспекти створення корпоративних бібліотечно-інформаційних систем розроблені у дослідженнях А. Б. Антокольського, Н. І. Апшай, Ф. С. Воройського, Н.В.Дунаєвої, Є. Корнилової, Дейла Пітера, Н. Ф. Самохіної. Учені, аналізуючи реально втілені проекти з коопераційної діяльності бібліотек різних країн, виділяють в якості найпоширеніших: зведені каталоги, бібліотечні системи корпоративної каталогізації, регіональні корпоративні бібліотечноінформаційні системи, міжрегіональні та міжвідомчі об'єднання бібліотек.

Аспекти формування ресурсної бази інформаційного забезпечення освіти, науки і культури в умовах регіону відображені в роботах Д. М. Грибкова, Т. М. Костирко, В. В. Лучанської, О. Ю. Мар'їної, Г. В. Шемаєвої. Дослідники відзначають, що умовами інтеграції освітньо-наукових і культурних закладів $€$ добровільне об'єднання учасниками інформаційних ресурсів та технологій, формування організаційно-структурної єдності, що вимагає функціональних трансформацій, управлінських інновацій, розвитку стратегій професійної комунікаційної взаємодії фахівців бібліотек, архівів, музеїв, інформаційних центрів тощо.

Розвитку партнерства і взаємодії бібліотек ВНЗ в умовах інформатизації, реалізації ними корпоративних проектів присвячені праці П. Брофі, Т. Срьоменко, Т. М. Костирко, Н. Петриної, Л.І.Шпукал, Т. О. Ярошенко. Бібліотекознавці підкреслюють, що регіональна інтеграція всіх сфер діяльності бібліотек вишів, яка є процесом бібліотечної взаємодії, що призводить до зближення бібліотечних механізмів у формі регіональних угод і координації регульованими міжбібліотечними органами, відбувається в процесі адаптації. Розвиток корпоративних об'єднань бібліотек ВНЗ здійснюється за умови подолання протиріч, підпорядкування власних цілей загальній меті розвитку, взаємного пристосування і трансформації елементів. Основою налагодження і гармонізації міжбібліотечних інтеграційних відносин повинно стати спільне бачення ефективності соціально-комунікаційної взаємодії бібліотек, єдність цілей взаємодії, розуміння єдності інформаційно-комунікаційної політики.

Аналіз літературних джерел щодо формування єдиного інформаційнокомунікаційного простору освіти та системного інтегрування до нього всіма складовими своєї діяльності бібліотек ВНЗ, дозволяє визначити початок цих процесів на пострадянському просторі з кінця 90-х років XX сторіччя. Початок інтеграційному руху був покладений Росією і позначився створенням корпоративних бібліотечних систем за регіональною ознакою (РКБІС) $[15,19]$, умовою формування яких є єдність програмно-технологічних підходів та методичних засад. Слід відмітити, що російські бібліотеки вишів виступили лідерами в створення регіональних корпоративних бібліотечних систем та активними учасниками їх розвитку: ще у 2003 р. в Росії нараховувалось 165 учасників РКБІС, 3 них - 66 (або 40\%) складали бібліотеки вищих закладів освіти [3]. Саме бібліотеки ВНЗ складають основу таких РКБІС, як «Корпоративная библиотечная система вузов Санкт-Петербурга» та «Корпоративная библиотечная сеть Омского региона»; у РКБІС «Корпоративная библиотечная сеть Казани» та 
«Consensus Omnuim: корпоративная сеть библиотек Урала (Екатеринбург)» їх чисельність складає більше половини.

В Україні відсутня загальна статистика реалізації бібліотечних корпоративних проектів як на державному, так і на регіональному, місцевому або галузевому рівнях. Лише дослідження «Інтеграція бібліотек ВНЗ України: сучасний стан та перспективи розвитку» (січень-березень 2010 р.) [8], що охопило практично всі регіони держави, дозволило вперше визначити рівень інтеграційних ознак, якими характеризується діяльність бібліотек вищих навчальних закладів України, та вектор їх спрямування. Маючи за предмет дослідження інтеграційні процеси бібліотек вишів держави на сучасному етапі розвитку соціальних комунікацій, науковці довели, що 87,5 \% від загальної кількості респондентів, яка складає 263 бібліотеки ВНЗ III-IV рівнів акредитації, приймають участь у будьяких корпоративних проектах. Загальна кількість проектів, заявлена респондентами, - 46; кількість установлених учасників - 204. При цьому більшість цих проектів реалізується на регіональному рівні. Саме регіональні стратегії інформаційно-комунікаційної взаємодії бібліотек ВНЗ дозволяють прискорити створення цілісної концепції їх міжвідомчої взаємодії і забезпечують значні переваги продуктивного інтеграційного середовища перед ізольованим. Дослідники визначили найбільш необхідні та перспективні вектори розвитку інтеграційних проектів, отримали дані про напрямки реалізації інформаційно-комунікаційних стратегій, виокремили очікування фахівців від реалізації корпоративних об'єднань[8]. Можна стверджувати, що в цілому підсумки діяльності регіональних корпоративних об’єднань суттєво впливають на розвиток інформаційнобібліотечної інфраструктури тих областей, в яких вони були створені.

У розвинутих країнах, а також в Росії та Білорусії вже реалізовані проекти, засновані на кооперації зусиль бібліотек різних систем і відомств, різного рівня підпорядкування. Проте в Україні, незважаючи на загальну тенденцію зростання бібліотечно-інтеграційних процесів на регіональному рівні [8], зазначені тенденції вирішуються надзвичайно складно. Досить усталеним, враховуючи нинішні складні умови фінансування інформатизації, є міф щодо несвоєчасності інтеграції бібліотек ВН3 [7]. Тому актуальним $є$ визначення нових моделей та умов системної інтеграції бібліотек до єдиного інформаційного простору регіону, який $є$ складовою національного інформаційного простору.

На сьогодення в інформаційному просторі України існують декілька напрямків інтеграції регіональних інформаційних ресурсів:

- перший напрямок передбачає створення системи інформаційних ресурсів безпосередньо органами влади суб'єктів України та органів місцевого самоврядування. Регіональні програми інформатизації, які здійснюються відповідно до Постанови Кабінету Міністрів України про «Порядок формування та використання регіональної програми і проекту інформатизації» [14], передбачають в якості об’єкту інтеграції ті IP, які акумулюються органами влади. Відносно до формування регіонального бібліотечного простору це можуть бути, наприклад, проекти зі створення корпоративної мережі загальнодоступних бібліотек області. В ролі базових бібліотек виступають, як правило, обласні універсальні нау- 
кові бібліотеки [6]. Фінансування проектів такого напрямку інтеграції здійснюється за рахунок обласних та місцевих бюджетів, підтримки різноманітних фондів («Відродження», «Фонд Сороса» та ін.), участі бібліотек у різноманітних грантах, спонсорської допомоги;

- другий напрямок пов'язується з початком розробки та проектування в Україні регіональних ресурсних баз інформаційного забезпечення освіти та передбачає створення ресурсних центрів регіонів - Центрів знань. Центри знань як ресурсоорієнтовані середовища підтримки діяльності, інноваційних методів навчання передбачають колективне створення та потужний супровід за широким тематичним та проблемним спектром для подальшого розвитку освіти в Україні [10]. В такому центрі консолідуються як власно самі IP ВН3 (ЕК, бази даних, електронні бібліотеки, електронні підручники, енциклопедична та довідкова література, публікації викладачів, контентне наповнення сайтів/порталів), так і технологічна база (обчислювальні, телекомунікаційні, програмні ресурси і сервіси вишів регіону). Побудова і розвиток масштабної регіональної розподіленої інформаційно-освітньої системи можливі тільки на базі кооперативної моделі об'єднання навчальних закладів, що працюватимуть на добровільній основі в рамках узгодження єдиних стандартів. Центр створюється на базі технологічно найпотужнішого ВНЗ регіону. Передбачається, що фінансування здійснюватиметься самими ВНЗ на паритетній основі із залученням фінансової підтримки різноманітних фондів, участі вишів у міжнародних (державних, регіональних) освітніх та науково-дослідних програмах, отримання грантів, спонсорської допомоги та регіонального фінансування.

- третій напрямок інтеграції інформаційних ресурсів регіону реалізується в рамках регіональних інформаційних систем інформаційної підтримки підприємництва. Його фінансування здійснюється за рахунок самих підприємств.

- четвертий, принципово новий для України напрямок пов'язаний із започаткуванням регіональних інтеграційних процесів, вектор яких спрямований на формування нового єдиного інформаційного простору освіти, науки і бізнесу із забезпеченням взаємодії між ними. Початок цього процесу в Україні дав розвиток кластерів; саме кластерний підхід є дієвою основою для створення нових форм об'єднання знань. По суті, кластеризація є високопродуктивною та конкурентноздатною формою кооперації (cluster, англ. - зростати разом), яка об'єднує для досягнення єдиної мети в гнучку мережу освітні та науководослідні заклади, виробничі компанії, постачальників комплектуючих, обладнання та послуг, фінансові інститути, державні органи, інші співпрацюючі організації [17]. Кластер характеризується концентрацією на єдиному просторі (географічному i/aбо інформаційному); спеціалізацією; множиною та різноманітністю його учасників; кооперацією та конкуренцією. В усьому світі програми підтримки кластерів розвиваються в рамках регіональної політики, політики 3 розвитку науки, освіти і технологій, промислової політики. При цьому передбачається направлення значних державних та приватних ресурсів, в тому числі, на розвиток середовища генерації знань - забезпечення доступності систем інформації, створення міжвузівських медіацентрів, наукових бібліотек, центрів 
колективного користування науковим обладнанням. 3 огляду на це, відносно до бібліотечної сфери можна вважати кластер як нову модель регіональної інфраструктури бібліотечно-інформаційного середовища.

Таким чином, з огляду на тему дослідження, з перелічених напрямків інтеграції регіональних інформаційних ресурсів для освітньої, наукової та культурної сфери найбільш важливими об'єктами інтеграції є електронні ресурси вищих навчальних закладів, наукових установ, закладів культури.

Головною умовою реалізації всіх напрямків інтеграційних процесів $\epsilon$ інформатизація. Механізмами реалізації концепції інформатизації на рівні регіону в бібліотечно-інформаційній сфері слід вважати: регіональні програми (підпрограми, підрозділи в обласних та місцевих програмах розвитку культури) 3 інформатизації на рівні регіонального утворення; плани інформатизації в окремих бібліотеках регіональних утворень; програми з інформатизації ВНЗ регіону (підпрограми інформатизації бібліотек вишів); програми 3 інформатизації наукових установ (підрозділи щодо інформатизації наукових бібліотек).

В залежності від статусу об'єднань і поставленої мети на сьогодення в склад бібліотечно-інформаційних кооперацій і корпорацій регіону, що складають окремі інформаційні системи, входять: або множина різних типів організацій (бібліотеки всіх видів, форм власності і рівнів підпорядкування, інформаційні центри, архіви, музеї та ін.); або об'єднання масових бібліотек (як правило, під керівництвом обласних наукових бібліотек); або корпорації бібліотек ВНЗ (територіальні або галузеві), або сукупність галузевих бібліотек.

Враховуючи, що кластеризація в бібліотечно-інформаційній сфері України є новою формою інтеграції, розглянемо ії більш детально.

Вчені визнають, що в умовах глобалізації джерелом конкурентноздатності регіонів стає вдале використання місцевих особливостей. В цьому сенсі особливої уваги потребує кластерний підхід як інноваційна технологія управління розвитком регіону та дієва основа для створення нових форм об'єднання знань. В нових економічних умовах розвиток бібліотечно-інформаційної сфери, пов'язаний із запровадженням інформаційно-комунікаційних технологій, уможливлює врахування теоретичних наробок та технологічних прийомів, що мають місце в інших сферах суспільного життя, насамперед - в сучасній економічній діяльності.

В умовах формування нового суспільства інтерес до кластерної концепції багато в чому пов'язаний з працями економіста Майкла Портера, за визначенням якого кластер (англ. Cluster - скупчення) розуміється як група географічно сусідніх взаємопов'язаних компаній і зв'язаних з ними організацій, що діють у визначеній сфері (наприклад, університетів, агентств зі стандартизації, торговельних об'єднань). Ця група характеризується спільністю діяльності і взаємодоповненням один одного [13].

В рамках Європейського союзу згідно доповіді Організації економічної співпраці та розвитку (OECD) «Конкурентні регіональні кластери: підходи до національної політики» [22] програми підтримки кластерів розвиваються в рамках регіональної політики, політики з розвитку науки, освіти і технологій, про- 
мислової політики. Значні державні та приватні ресурси направляються, в тому числі, на розвиток середовища генерації знань - забезпечення доступності систем інформації, створення міжвузівських медіацентрів, наукових бібліотек, центрів колективного користування науковим обладнанням. Формування та розвиток регіональних кластерів оцінюється як важлива конкурентна перевага сучасної економіки, забезпечуюча синергетичний ефект.

Найбільш успішними прикладами регіональних кластерів в різних державах є: «Силіконова долина» в США; Бенгалор в Індії; Монпельє у Франції; кластер «Біо-Долина», що розташований на граничній території Франції, Германії, Швейцарії. Одним 3 перших кластерів в Росії став кластер в Самарській області, що об’єднав Самарський держаний аерокосмічний університет, Поволжський центр космічної геоінформатики, Інноваційно-інвестиційний фонд Самарської області, регіональний технопарк [17]. У Санкт-Петербурзі активно розвивається профільний кластер оптичних технологій на базі технопарку СанктПетербурзького державного університету інформаційних технологій [16]. 32010 р. в підмосковному Сколкові розпочато створення високотехнологічного кластеру - «Кремнієвої долини Росії» [12]. 32000 р. в Україні започатковано ряд проектів для розвитку кластерних структур з пріоритетних для областей напрямків розвитку науки, техніки і виробництва в декількох регіонах - Донецькому, Львівському, Хмельницькому, Автономній республіці Крим [1, 2]. 32010 р. впровадження проекту розпочато в Дніпропетровській області.

У розвинутих країнах Заходу завдяки сучасним медійним технологіям і методам трансляції та тиражування (поліграфія, звукозапис, відео, радіо, телебачення, мультимедіа, Інтернет) усталеною практикою є формування регіональних творчих або інтелектуальних кластерів, які створюють і продають продукти інтелектуального виробництва: інформаційні ресурси, комп'ютерні та мультимедійне технології, музику, живопис, моду, дизайн, кіно- , теле-, радіо- і Інтернет продукцію тощо [5].

Активний наступ дигіталізації, поступовий перехід до домінування електронної книги, деяка втрата друкованою книгою свого значення як джерела інформації, але їі зростання як джерела розваги, приводять до об'єднання в кластери книготоргових установ [11].

Бібліотечна спільнота розвинених країн, враховуючи значні переваги об'єднання та співпраці бібліотек, заснованих на нових інформаційних технологіях, з кінця ХІХ століття теж залучилась до кластеризації.

Так, з 1992 року з метою створення єдиної європейської бази даних стародруків (Hand Press Book Database - HPB) об'єднались найбільші наукові бібліотеки Європи, включаючи бібліотеки вищих закладів освіти. Цей проект отримав назву «Консорціум європейських наукових бібліотек - Consortium of European Research Libraries (CERL)» [9]. Учасниками проекту з формування зведених каталогів національного i міжнародного рівнів та розширення доступу до колекцій є більше 50 бібліотек, в тому числі - Російська національна бібліотека (РНБ, Санкт-Петербург). Однією $з$ форм членства в CERL є кластер - група бібліотек, які мають доступ до бази даних Консорціуму під егідою однієї з ве- 
ликих наукових бібліотек регіону/держави, яка є дійсним, повноправним членом CERL. Кластерні групи поширені в Німеччині (21 бібліотека об'єднані в 2 кластери), Італії (48 бібліотек об’єднані в 5 кластерів), Франції (15 бібліотек об’єднані в 2 кластери), Великобританії (8 бібліотек об'єднані в 1 кластер), Португалії (3 бібліотеки об’єднані в 1 кластер), Іспанії (3 бібліотеки об'єднані в 1 кластер), Угорщини (16 бібліотек об'єднані в 1 кластер), Хорватії (7 бібліотек об'єднані в 1 кластер) [21]. Російська національна бібліотека взяла на себе зобов'язання з організації кластеру, в який вступили, підписавши угоду, дванадцять російських наукових бібліотек [4].

В Італії з 2003 року проект «ДЕЛОС - Збереження цифрових кластерів» (DELOS - Digital Preservation Cluster) інтегрував групу цифрових бібліотек з метою проведення досліджень в області збереження електронної спадщини, розробки передових технологій, методів, інструментарію і функцій електронних бібліотек [20].

32009 р. у Киргизстані розпочато формування освітнього кластеру в бібліотечній справі, який передбачає інтеграцію освіти, науки і практики в процесі підготовки бібліотечних фахівців [18].

Будь-якої інформації щодо формування в Україні кластерів як форми інтеграції бібліотек ВНЗ зокрема, так і установ освітньо-наукової та культурної сфери взагалі, в ході проведення дослідження не знайдено.

Спираючись на викладену інформацію, а також беручи до уваги необхідність інтенсифікації інтеграційних процесів соціально-комунікаційних інституцій регіону на базі інформаційно-комунікаційних технологій, вважаємо за можливе застосувати кластерну теорію в якості підгрунтя мережевої взаємодії на основі принципів: формування єдиного інформаційного простору; удосконалення бібліотечно-інформаційних процесів і технологій; формування загальної політики діяльності; підвищення професійного рівня фахівців.

Формування кластеру як форми об'єднання суб'єктів інформаційнокомунікаційної взаємодії регіону може відбуватися за умови природного явища або результату індукції. Якщо кластеризація $є$ природним процесом, імпульсом до виникнення якого може виступати якась конкретна i, інколи, термінова необхідність, процесом, в якому все залежить від бажання самих учасників інтеграції сформувати кластер, який буде стимулювати їх розвиток, а також розвиток регіону і держави в цілому, то роль держави полягає тільки в сприянні. В іншому випадку держава $є$ не тільки ініціатором, але й найбільш активним учасником кластеру. Саме вона визначає сфери, в яких можливо формування найбільш ефективних кластерів, та їх учасників.

На сьогодення в Україні в умовах відсутності єдиного державного координаційного, методичного, науково-дослідницького центру 3 питань бібліотечноінформаційної діяльності інтеграційні процеси відбуваються, як правило, за рахунок розвитку ініціатив на місцях [8]. Таким чином, можна стверджувати, що можливе формування кластерів та корпорацій освітньо-наукової та культурної сфери в державі відбуватиметься природним шляхом, тобто, кластеризація та корпоратизація $є$ природними формами інтеграції суб'єктів інформаційно-комунікаційної взаємодії. 
При створенні кластеру установ, формуючих освітні, наукові та культурні ресурси регіону, можна виокремити в якості ключових елементів, що визначають регіональний кластер, наступні його характеристики, які можна розглядати і як умови їх інтеграції:

- концентрація на єдиному просторі (географічному і/або інформаційному);

- спеціалізація: кластери концентруються навкруги визначеної сфери діяльності - формування єдиного освітньо-науково-культурного простору регіону, до якої мають відношення всі учасники інтеграційного процесу. При цьому умовою $є$ наявність в кластері «локомотиву» - лідируючого (інтегруючого) продукту/ресурсу або послуги;

- ініціатива знизу, як необхідна умова створення та ефективного розвитку кластеру, коли самі потенційні учасники приходять до бажання та дій щодо об'єднання в кластер;

- множина та різноманітність учасників кластера: бібліотеки, бібліографічні і інформаційні центри, архіви, музеї, ВНЗ, постачальники, видавництва, наукові товариства, різні організації з розробки інформаційної техніки і технологій;

- співпраця та конкуренція як основні види взаємодії між членами об'єднання;

- превалювання горизонтальних, вільних від ієрархічної організації, зв'язків;

- життєвий цикл кластеру: маючи тимчасовий характер, в той же час розраховані на довготривалу перспективу;

- включеність в інноваційний процес (учасники об'єднання залучені в технологічні, функціональні, організаційно-управлінські інновації);

- безперервність процесу взаємного навчання. Індивідууми в одній або споріднених сферах мають тенденцію поділяти власний досвід з іншими, офіційно - через професійні зв'язки і неофіційно - через різного роду неформальний обмін. Тому безперервна багатоаспектна взаємодія в схожій, але взаємодоповнюючій діяльності, $є$ умовою і характеристикою створення кластеру;

- ефект синергетичної взаємодії, який передбачає головним чином необхідність засвоєння не стільки технології створення окремих компонентів об'єднання, скільки створення між ними ефективних синергетичний зв'язків, що можливо за умови тільки одновекторності (спеціалізації) кластеру.

Таким чином, в рамках даної роботи можемо визначити кластер установ освітньо-науково-культурної сфери як добровільне об'єднання географічно близьких, маючих в основному галузеву спрямованість, взаємодіючих та взаємодоповнюючих центрів генерації, обробки, накопичення і передачі знань (ВН3, бібліотеки, наукові установи, виробничі інформаційні компанії, архіви, музеї, інформаційні центри, книговидавничі установи, громадські організації та ін.), функціонуючих на базі новітніх інформаційних технологій.

Кластер установ освітньо-науково-культурної сфери може мати різні структури: 
- ядерну, з формуванням навкруги центру - крупного університету, науководослідного та інформаційного центрів, бібліотечних установ, архівних та музейних закладів тощо;

- багатоядерну, з об’єднанням кількох центрів. При цьому кожне ядро керується власними цілями, завданнями і пріоритетами.

Враховуючи можливий конфлікт інтересів, для координації дій та підвищення ефективності взаємодії необхідною умовою є створення окремої структури за участю всіх учасників інтеграційного процесу - Координаційного центру. Координаційний центр, з однієї сторони, представляє інтереси кожного з учасників кластеру (як окремих установ в ядерному об'єднанні, так і центрів в багатоядерному об’єднанні), з іншої, - задає загальний напрямок руху в інтересах всього об'єднання.

Таким чином, наявність формальної інституціональної структури, координуючої розвиток кластеру, є однією з умов впровадження кластерів. Ще однією умовою розвитку кластерів $є$ ініціатива та сумісні, взаємодоповнюючі зусилля членів кластерної кооперації та адміністрації регіону. Роль адміністрації може складатися з підтримки та ініціації процесів активації кластерів, урегулюванням різних питань кластеру з іншими рівнями влади.

Будь-якому кластеру притаманна внутрішня динаміка, пов'язана 3 наявністю конкуренції та кооперації, що виникає між його учасниками. Так, конкуренція формує тенденцію до удосконалення технологічних та управлінських процесів кожного суб'єкту інтеграції (скорочення витрат, підвищення якості, залучення нових користувачів інформації, розширення асортименту послуг тощо), його внутрішньої спеціалізації. В той же час, діючи на одному рівні, учасники кластеру кооперуються навкруги основної діяльності, використовуючи власні ключові здібності, щоб доповнювати один одного. Діючи разом, учасники об'єднання здатні залучати ті ресурси та послуги, які були їм недоступні в ізоляції. Таким чином, наявність кооперації та конкуренції є умовою створення та розвитку кластеру.

Оскільки розвиток кластерів передбачає сумісне зростання кожного з членів об'єднання, то умовою його успішного розвитку повинні бути нові, оригінальні, нестандартні інноваційні ідеї, які зможуть весь час надавати нові імпульси, визивати зацікавленість як самих учасників інтеграційних процесів, так і потенціальних інвесторів.

Інтелектуальна обробка документів, діяльність із консолідації інформації (створення аналітичних, аналітико-прогностичних матеріалів; проведення бібліо-, інформо- та наукометричних досліджень у сховищах даних і екстракції нових знань, що в явному вигляді в них не містяться), сучасні засоби збереження і надання інформації, сумісна діяльність в умовах мережевих структур потребують постійних заходів з підготовки та перепідготовки фахівців всіх установ, які входять до кластерів. Тому організація заходів 3 підвищення кваліфікації з урахуванням роботи в корпоративних структурах, корпоративної культури, етики корпоративних відносин є наступною необхідною умовою кластеру як форми інтеграційного об'єднання. 
Концептуальна схема освітньо-науково-культурного кластеру регіону (див. Малюнок 1), яка має «ядерну» структуру, включає в себе два рівня: ядро (сукупність регіональних інституцій соціальної взаємодії - ВНЗ, бібліотек, архівів, музеїв, ЗМІ, центрів інформації, книговидання, служб НTI, кіно-фотоіндустрії тощо) та оболонку (адміністрація регіону, благодійні фонди, грантодавці, потенційні інвестори тощо). Саме оболонка може забезпечувати допомогу місцевої влади в організації кластерів в регіоні, залучення фінансових вкладень в кластери, лобіювання інтересів суб'єктів кластерів тощо.

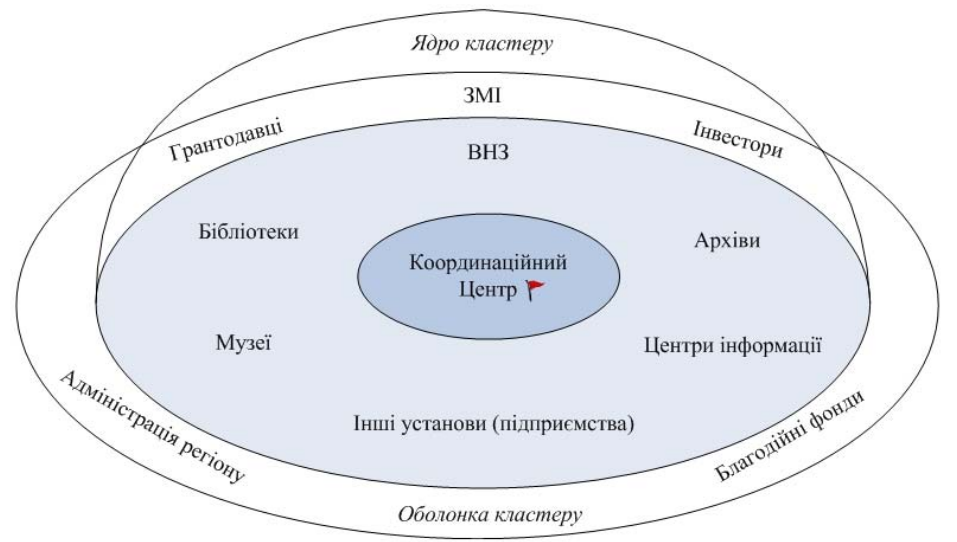

Малюнок 1. Концептуальна схема кластеру.

Об’єднання в кластер на основі взаємовигідної кооперації бібліотек усіх типів і видів, наукових установ, дослідницьких та інформаційних центрів, закладів соціально-культурної сфери, невеликих інноваційних підприємств, дозволить сформувати загальний синергетичний ефект i підвищити його конкурентноздатність.

Таким чином, інтеграція бібліотек ВНЗ та інших суб'єктів соціальнокомунікаційної взаємодії на рівні регіону, що мають за мету побудову мережевих інформаційних структур на основі використання новітніх засобів зв'язку та впровадження інноваційних технологій, можуть відбуватись на різних принципах соціальної організації: координації; кооперації і кластеру як іiї найактуальнішої на сьогодення регіональної моделі об'єднання; корпорації як основної форми міжбібліотечної взаємодії. Попередній аналіз складових успішної інтеграції бібліотек ВНЗ до соціально-комунікаційної інфраструктури регіону за рахунок використання різних принципів соціальної організації, звернення до праць М. П. Войнаренка щодо формування кластерних моделей в економіці, дозволяють сформувати наступну схему моделі інтеграції бібліотек ВНЗ (Див. 
Малюнок 2). При цьому, створення інтеграційних моделей в бібліотечноінформаційній сфері знаходиться між двома умовно окресленими трикутниками: моделестворюючим - три «К» (комунікація, концентрація, конкуренція), який істотно впливає на утворення моделей інтеграції, і моделепідтримуючим три «С» (співпраця, спеціалізація, синергія), сприяючим якісним змінам в результаті створення моделей інтеграції. Різноманітні моделі інтеграції формуються на основі різних принципів соціальної організації: координації; кооперації/кластеризація; корпоратизації.

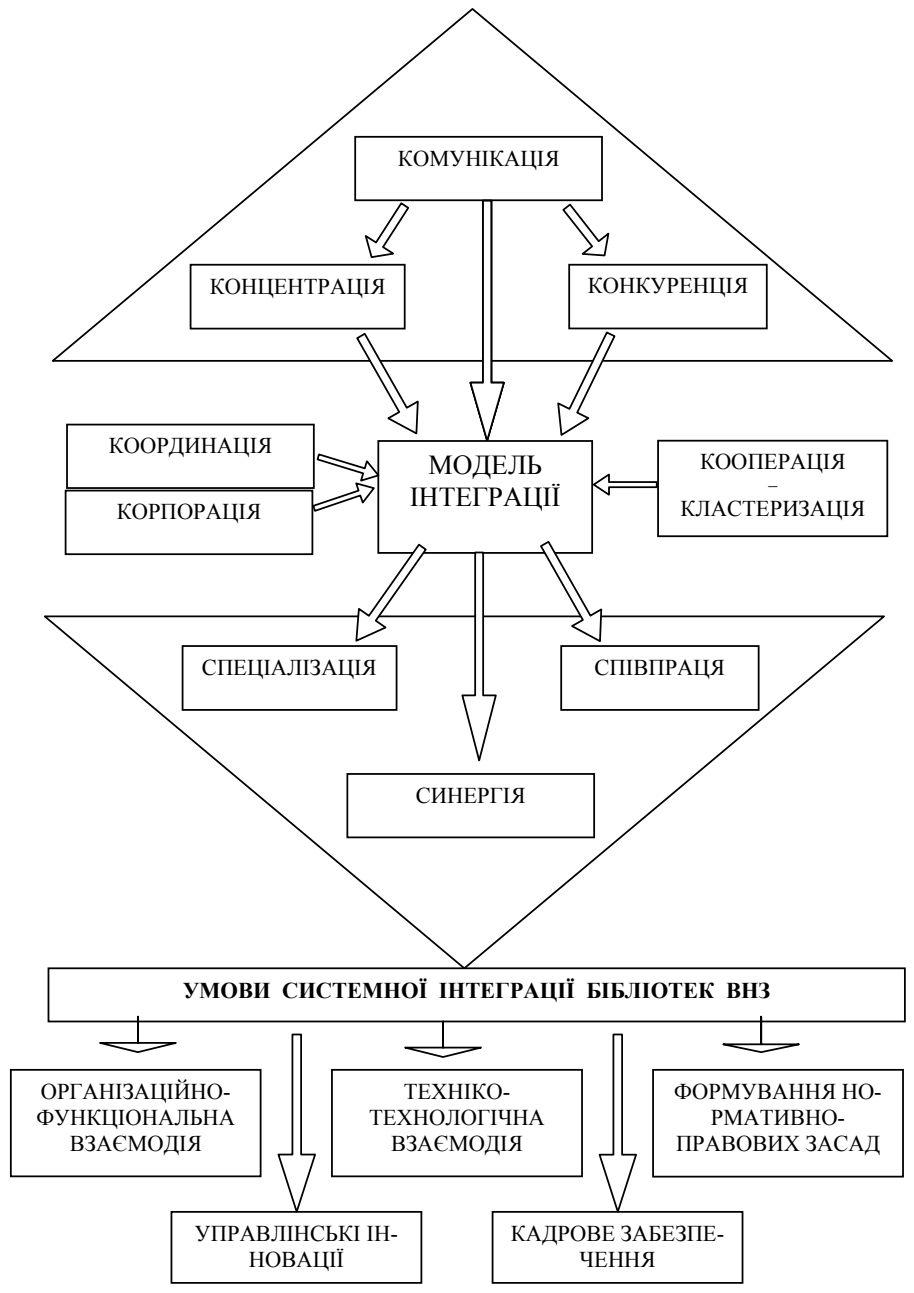

Малюнок 2. Модель інтеграції бібліотек ВНЗ 
Підгрунтям для формування інтеграційних моделей в даній схемі виступають умови системної інтеграції бібліотек ВНЗ до соціально-комунікаційної інфраструктури регіону. Ними $є$ : організаційно-функціональна взаємодія, техніко-технологічна взаємодія, управлінські інновації, формування нормативноправових засад, кадрове забезпечення. Саме вони передбачають об'єднання потенціалу і зусиль на добровільній основі і спільному інтересі, впровадження інновацій та запровадження різноманітних ініціатив за наявністю координуючого центру, посилення системних зв'язків інформаційно-бібліотечного спрямування та організацію системи підвищення кваліфікації, концентрацію засобів та зусиль на пріоритетних напрямках, створення умов для успішної діяльності всіх членів об’єднання в конкурентному інформаційному середовищі.

Всі ці умови забезпечать системну інтеграцію бібліотек ВНЗ в освітньонауковий і культурний інформаційний простір регіону, щоб інтеграційні моделі відбулися як життєдіяльні, самодостатні, успішні та ефективні організації.

\section{СПИСОК ДЖЕРЕЛ}

1. Войнаренко, М. П. Кластерные модели объединения предприятий в Украине / М. П. Войнаренко // Экономическое возрождение России. 2007. - № 2(12). - c. 75-86

2. Войнаренко, М. П. Кластерные модели объединения предприятий в Украине / М. П. Войнаренко // Экономическое возрождение России. 2007. - № 4(14). - c. 68-82

3. Воройский, Ф. С. Корпоративные автоматизированные библиотечноинформационные системы: состояние, принципы построения и перспективы развития: (Аналитический обзор) / Ф.С. Воройский, Я. Л. Шрайберг. - М.: ГПНТБ, 2003. - 123 с.

4. Генеральная сессия Консорииума Европейских научных библиотек [Электронный ресурс] // РНБ-Информачия. - 2002. - № 11. - Режим docmyna: http://www.nlr.ru/news/rnbinfo/2002/11-1.htm

5. Гнедовский, М. Творческие индустрии: политический вызов для России [Электронный ресурс] / М. Гнедовский // Отечественные записки. - 2005. - № 4. - Режим docmyna: http://magazines.russ.ru/oz/2005/4/ 2005_4_15.html\#s3

6. Іваницька, А. С. Корпоративний підхід до створення $і$ використання регіональних електронних інформаиійних ресурсів [Електронний ресурс] / A. C. Іваницька. - Режим доступу: http://www.library.kr.ua//...// ivanycka.html

7. Колесникова, Т. О. Бібліотечні міфи інформаційного суспільства / Т. О Колесникова // Освіта регіону. - 2009. - №4. - С.155-161

8. Колесникова, Т. О. Інтеграиія бібліотек ВНЗ Украӥни: сучасний стан та перспективи розвитку (за результатами соціологічного дослідження) / Т. О. Колесникова // Наукові пращі Наџіональної бібліотеки України ім. В. І. Вернадського. Вип. 28. - К., 2010. - с. 209-217. 
9. Консорииум европейских научных библиотек (Consortium of European Research Libraries) [Электронный ресурс]. - Режим доступа: http://www.nlr.ru/inter/cerl.htm

10.Костирко T. Формування ресурсної бази інформаційного забезпечення освіти в умовах регіону / Т. Костирко // Вісник Книжкової палати. 2008. - № 2. - c. 25-27.

11.Московская международная книжная выставка-ярмарка - 2007: успешное начало нового книжного сезона [Электронный ресурс]. - Peжим достуna: http://www.knigdelo.ru/default.asp?id=9\&news_id $=1598$

12.Паркер Б. Инновачии: Формула Кремниевой долины [Электронный ресурс] / Б. Паркер. - Режим доступа: http://www.vedomosti.ru/newspaper/article/2010/07/27/241714

13.Портер М. Конкуренция: Пер. с англ.. - М.: Издательский дом «Вільямс», 2005. $-608 \mathrm{c}$.

14.Про порядок формування та використання регіональної програми $i$ проекту інформатизації: Постанова Кабінету Міністрів України від 12 квітня 2000 р. № 644 [Електронний ресурс]. - Режим доступу: http://ua-info.biz/legal/basezp/ua-zmehgt.htm

15.Ресурсы российских корпоративных библиотечных систем [Электронный ресурс]. - Режим доступа: http://www.ruslan.ru:8001/rus/rcls/ resources/. - Загл. с экрана

16.Стамевская, Г. Н. Формирование механизма развития инновационного кластера на базе профильного технопарка: автореф. дис. на соиск.....канд. эконом. наук [Электронный ресурс]. - С.-Пб, 2009. - Режим доcmyna: http://www.finec.ru/thesis/d09stashevskayagn.doc

17.Суворов, А. Е. Кластерная экономика и эффективное государство. Самарский опыт [Электронный ресурс] / А. Е. Суворов. - Режим доcmyna: http://cskp-samara.ru/files/doc_7.doc

18. Шаймергенова, Т. А. Образовательный кластер в библиотечном деле [Электронный ресурс] / Т. А. Шаймергенова. - Режим доступа: http://conference.bik.org.kg/uploads/papers/papers2009/

Shaimergenova.pdf

19.Шрайберг Я. Л. Автоматизированные библиотечно-информационные системы России: состояние, выбор, внедрение, развитие / Я. Л. Шрайберг, Ф. С. Воройский. - М.: Либерея, 1996. - 271 с.

20.Digital Preservation Cluster (WP6) [Virtual Resource]. - URL: http://www.dpc.delos.info/

21.List of Members CERL [Virtual Resource]. - URL: http://www.cerl.org/web/en/membership/list_members

22. OECD (2007), Competitive Regional Clusters: National Policy Approaches [Virtual Resource]; ISBN 978-92-64-02708-4. - URL: http://www.oecd.org/publications/Policybriefs. 


\section{2. ИНФОРМАЦИОННЫЕ РЕСУРСЫ ОТРАСЛЕВЫХ НАУЧНО- ТЕХНИЧЕСКИХ БИБЛИОТЕК ОТКРЫТЫ СТУДЕНТАМ}

Любая библиотека существует для читателей, независимо от ее статуса и подчинения. Проводимые в последнее время реформы обусловили изменения в системе высшего образования, которые, в свою очередь, вызвали лавинообразный поток студентов в библиотеки всех уровней, особенно - в научнотехнические. Эта категория молодежь составляет от $25 \%$ до $50 \%$ читателей отраслевых библиотек.

Не является исключением и Государственное учреждение «Центральная государственная научно-техническая библиотека горно-металлургического комплекса Украины» одна из крупнейших отраслевых библиотек, фонд которой насчитывает более 1,5 млн. экземпляров. Ежегодно ее фондами обслуживается стационарно и виртуально более 50000 пользователей. Анализ состава ее читателей показал, что доля специалистов, неуклонно уменьшавшаяся на протяжении 10 лет, сейчас стала увеличиваться и достигла 60\% (т.е. уровня 1987 г.). Число научных работников последние 10-13 лет остается стабильным (около $10 \%)$. Доля студентов составляет $30 \%$.

Формы выявления информационных потребностей в библиотеках различны, но все они складываются из определенных фрагментов и базируются на ряде элементов.

В их числе директивные и программные материалы, публикации в прессе по злободневной тематике, статистические данные, нормативные и учебнометодические разработки для образовательных учреждений позволяющие сформировать представление о потенциальном спросе. Это необходимая работа, но недостаточно полная.

Выявлению же реального спроса способствует анализ:

- запросов пользователей;

- читательских формуляров и структурыкниговыдачи с определением наиболее актуальной тематики используемых источников информации, а в ее рамках видового и хронологического состава документов;

- содержания и причин отказов при выполнении читательских запросов;

- востребованности различных видов услуг и оценка их качества.

По итогам проведенного в 2009г. маркетингового исследования «Государственная отраслевая библиотека: какой ей быть?» были внесены некоторые изменения в систему обслуживания пользователей - открыты зал литературы повышенного спроса, центр экологической информации, расширены помещения специализированных отделов. На вопрос: «Всегда ли Вы находите в ГУ «ЦГНТБ ГМК Украины» нужную Вам литературу?» 95\% ответили «Да». В первую очередь, это говорит о соответствии каталогов и картотек литературе и документам на полках, после проведенной сверки фонда, которая длилась не один год. На вопрос: «Оцените профессиональную квалификацию библиотекаря» 90\% респндентов ответили «очень высокая».

Профессионализм работников ГУ «ЦГНТБ ГМК Украины» обеспечивается благодаря следующим факторам, которые складываются в единую цепочку 
улучшения производительности труда, интеллектуального роста сотрудников, качественного обслуживанния пользователей:

- рациональная организация технологии труда на каждом рабочем местеи в библиотеке в целом;

- проведение методическим отделом библиотеки ежемесячной учебы, где работников информируют о новшествах библиотечной работы;

- самостоятельное повышение свого профессионального уровня библиотекарями.

Наличие высококвалифицированных работников является одним из важнейших факторов повышения продуктивности труда, обеспечения конкурентноспособной продукции.

В основе деятельности библиотеки лежит многоуровневая организация системы обслуживания, обеспечивающая универсальное справочное обслуживание по всему тематическому спектру, углубленное информационное обслуживание по приоритетным тематическим направлениям, специализированное обслуживание в зоне удаленного доступа, а также предоставление комплекса стандартно-офисных услуг.

Общий пакет предлагаемых услуг составляет более 40 наименований.

Среди основных следует отметить:

- справочное обслуживание, состоящее в выполнении разовых тематических и фактографических запросов, включая и определение наличия конкретных изданий в фондах библиотеки через электронный каталог;

- углубленное информационное обслуживание по предложенной тематике;

- подбор статей по оглавлениям журналов, получаемых библиотекой за все года (база данных оглавлений журналов ЦГНТБ ГМК Украины);

- выполнение сложных «отсроченных» запросов, которые не могут быть выполнены на основе первичного обращения к традиционному справочнопоисковому аппарату, визуального просмотра источников, а также с привлечением усилий высококвалифицированных библиографов основных и специализированных подразделений библиотеки;

- оформление документов для курсовых, дипломов, диссертаций, индексированию по УДК, библиографического описания;

- рассылка информации о новых поступлениях отраслевым Вузам;

- репродуцирование, сканирование документов по запросам пользователей;

- предоставление доступа пользователей к Интернет и WWW-ресурсам, консультирование по навигации, открытие ящиков электронной почты, поиск информации по запросам пользователей;

- предоставление РС для самостоятельной работы;

- предоставление полнотекстовых документов электронной библиотеки;

- предоставление патентной и нормативно-технической документации;

- виртуальная библиографическая справка;

- консультирование по вопросам интеллектуальной собственности;

- патентный поиск информации; 
- проведение обучающих семинаров по привитию навыков взаимодействия с современной он-лайновой средой;

- библиотечно-библиографическое обучение студентов;

- межбиблиотечный обмен по запросам пользователей;

- ежемесячные дни информации.

У студентов вузов большим спросом пользуются тематические подборки, выпускаемые ГУ «ЦГНТБ ГМК Украины», «Горячая линия», которые содержат в себе репродуцированные документы по всем переделам металлургии и смежным отраслям производства с обширным аннотированным библиографическим перечнем литературы. Например: «Утилизация отходов - экологические и ресурсосберегающие аспекты», «Проблемы охраны и безопасности труда на современных производства», «Современное прокатное производство» и т.д.

Ежегодные аналитико-конъюнктурные обзоры литературных источников «Металлургия зарубежных стран» всегда интересны пользователям. В этом году подготовлена информация о состоянии развития металлургии в следующих странах: Россия, Бразилия, Япония, Австрия.

Создана картотека соответствия немецкого журнала ««Stahl und Eisen», получаемого библиотекой, российскому изданию «Черные металлы».

Пользователи, которые получают это издание, имеют возможность заказать переводы статей, реферативные тематические обзоры новейших иностранных технологий, которые необходимы им для рассмотрения и применения в работе.

Библиографические пособия являются промежуточным этапом для подготовки выставок литературы, дней специалиста и других мероприятий. С расширением использования информационных технологий как в процессе библиографического поиска, так и при составлении пособий, позволяет выявлять литературу, ориентируясь на совокупные информационные ресурсы общества, а результаты библиографического поиска предоставлять пользователям в электронном виде. Этот процесс обеспечивает многоаспектность отражения содержания документов; стабильное пополнение, актуализацию индивидуальных баз данных, формируемых по запросам пользователей; предоставление информации на рабочее место или по месту жительства абонента обслуживания.

Использование сетевых технологий резко повышает качество выполнения запросов территориально удаленных пользователей, позволяя обслуживать их через e-mail.

В помощь студентам, аспирантам, преподавателям библиотека ежегодно подготавливает библиографические пособия необходимой надлежащей тематики, а именно: «Частичное брикетирование угольной шихты», «Производство труб на беспрерывных состояниях на длинной оправке», «Защита метизов от коррозии», «Содержание и ремонт железнодорожных путей в черной металлургии», «Сравнительный анализ работы мартеновської печи и двухванного сталеплавильного агрегата», «Продувка стали инертными газами», «Математическое моделирование параметров и теории процессов холодной и горячей прокатки стальных полос на бнепрерывных и реверсивных станах», «Финансовое состояние предприятия», «Финансовая инфраструктура народного хозяйства Украи- 
ны» и др. Таким образом, успешно удовлетворяются тематические запросы, которые предусматривают подготовку аналитических обзоров, созданных на основе аналитик-синтетической обработки первичной информации.

Усложнившаяся система поиска информации требует от библиотек систематического обучения читателей основам библиографического поиска, поскольку $85 \%$ вузов сократили из расписания эти учебные занятия в курсе «Введение в специальность».

Одной из главных задач библиотеки как социального института является возможность и полнота предоставления доступа к информационным ресурсам.

Реализуется эта задача через структурирование библиотечного фонда по различным направлениям. Фонд должен быть организован так, чтобы одновременно были осуществлены две цели: эффективное использование и сохранение фонда для последующего использования.

Основой для достижения этих целей в ГУ «ЦГНТБ ГМК Украины» являютя консультационные услуги - традиционный вид деятельности для любой библиотеки и службы информации. Услуги этой группы предназначены для ответа на вопросы пользователей; «где и как я могу найти интересующую меня информацию?». Значимость консультационного обслуживания чрезвычайно велика и высоки требования к квалификации сотрудников, оказывающих подобные услуги. Это объясняется рядом причин.

Во-первых, консультирование пользователей является действенным средством повышения уровня их информационной культуры, ориентации в совокупных ресурсах и фонде конкретной библиотеки или информационной службы.

Во-вторых, предоставление таких услуг повышает эффективность использования ресурсов библиотеки.

В-третьих, очень часто подобные услуги являются замещением других, более сложных и дорогостоящих, которые в силу разных обстоятельств не могут быть предоставлены пользователю (например, когда пользователь не может оплатить их; сотрудники библиотеки не располагают временем на выполнение фактографических запросов или составление объемного библиографического списка; услуга не входит в ассортимент предлагаемой продукции). В этом случае появляется возможность вместо всегда крайне нежелательного отказа предложить потребителю помощь в самостоятельном разыскании нужной информации с использованием для этого кратчайшего и наиболее рационального пути. Именно поэтому в библиотеке консультационная помощь в поиске и выборе источников информации традиционно относится к числу бесплатных услуг.

Подобные услуги обычно осуществляются в несколько этапов: прием запроса; его уточнение; указание источника (источников) поиска с использованием подсобного СПА (путеводителей, указателей, библиографических пособий, каталогов информационных изданий, поисковых систем Интернет и т. д.); разъяснение правил работы с этими источниками. Если речь идет о нахождении документов из данного фонда, пользователя обучают правилам поиска по каталогам (традиционным и электронным). 
В настоящее время одной из самых востребованных услуг являются консультации по проведению поиска в сетевых информационных ресурсах. Результатом такого поиска в зависимости от запроса пользователя может быть самая разнообразная информация:

- документальная (полный текст определенной статьи, книги, закона, аналитического обзора и т. д.);

- библиографическая (тематический список литературы с указанием места ее хранения);

- фактографическая (биография конкретного лица; перечень тематических выставок $c$ указанием сроков и места их проведения и другая самая разнообразная информация). К фактографической информации можно отнести и предоставление адресов Веб-ресурсов: сайтов фирм, тематических порталов;

- аналитическая (гипертекстовая), полученная путем аналитикосинтетической переработки сведений из различных ресурсов сети.

Преимуществом комплексного поиска является возможность уточнения запроса, корректировки направлений поиска, отбор и оценка найденной информации, проведение поиска «По подобию».

Сегодня основная читательская группа ГУ «ЦГНТБ ГМК Украины» - «удаленный пользователь», которому не надо физически приходить в библиотеку достаточно зайти на ее сайт. Здесь представлен широкий спектр услуг и информационных продуктов: можно зарегистрироваться и отправить свой запрос в библиотеку, осуществить поиск в электронном каталоге, заказать и в считанные минуты получить электронную версию необходимого документа на свое рабочее место. Электронные журналы, новинки литературы, виртуальные выставки, возможность оставить запись в книге отзывов - это далеко не полный перечень того, что предлагает библиотека на своем сайте, информация на котором обновляется каждый день. Оперативная, доступная, актуальная информация - вот что дает сегодня научно-техническая библиотека специалистам.

Десять лет назад, когда ЦГНТБ ГМК Украины предстояло работать с предприятиями на договорных началах по принципу «заказчик - исполнитель», в коллективе было смятение и сомнение: сможет ли библиотека работать в таких непривычных для нее условиях? Организация такой работы потребовала больших усилий, собранности и отдачи от коллектива. И он не только смог это сделать, жизнь еще раз подтвердила то, что всегда отличало научно-техническую библиотеку: высокий уровень профессионализма, качество предоставляемых услуг и их целевая востребованность.

В библиотеке выделена особая группа потенциальных источников справочной информации, которые все активнее начинают использоваться в онлайновом справочно-библиографическом обслуживании (СБО). Это веб-сайт отраслевого характера, доступный пользователям, имеющий большие возможности для выполнения оперативных запросов при СБО, в том числе фактографического характера.

Все это создало платформу для формирования и рационального использования он-лайнового СБФ. Вебсайт библиотеки (www.cgntb.dp.ua) дает возмож- 
ность пользователю узнать о структуре, правилах и режимах работы библиотеки, ознакомиться с ее возможностями и услугами, где наиболее расширенными и актуальными являются:

- новости общего характера о библиотеке;

- каталог новых поступлений;

- традиционный и электронный запрос литературы;

- тематические просмотры и выставки литературы;

- библиографические списки к курсовым, дипломам, диссертациям;

- информация о фонде периодических изданий библиотеки;

- авторская книга;

- электронный читальный зал;

- тематические подборы;

- справочное обслуживание через электронную почту;

- обменно-резервный фонд ГУ «ЦГНТБ ГМК Украины»;

- обслуживание виртуальных пользователей.

Адаптированная локальная автоматизированная библиотечная система, разработанная ГУ «ЦГНТБ ГМК Украины» в 2007 году дала возможность библиотеке выйти на новый уровень качественного обслуживания благодаря новым информационным технологиям. Теперь фонд библиотеки, все ее базы данных отображены во всех поисковых системах глобальной сети Интернет, и даже когда библиотека не работает, читатель, который не имеет возможности посетить библиотеку стационарно, пользуется ее фондами, заказывает литературу. Тем самым намного увеличились количество пользователей библиотеки и книговидача. Расширился регион обслуживания - вся Украина и страны СНГ. Библиотекарь теперь прийдя на работу имеет уже полученные запросы на информацию.

Библиотека теперь хорошо известна как в Украине, так и в близком и далеком зарубежье как солидный и надежный партнер по справочноинформациному обслуживанию не только стационарно, а и в онлайновом режиме.

Электронный каталог пополняется ежедневно. Поиск можно осуществить по различным реквизитам: ключевому слову, автору, заглавию, предметным рубрикам, году издания, УДК и другим. Есть также комплексный поиск, то есть поиск по нескольким реквизитам сразу.

Эту услугу уже оценили читатели библиотеки, особенно студенты. Теперь, потратив несколько секунд на поиск, можно подобрать для работы или учебы всю необходимую литературу. Достаточно лишь распечатать библиографический список, и специалист отдела обслуживания подберет нужные издания. Кстати, библиографическое описание можно использовать для списка литературы при написании курсовой, дипломной работы или реферата, ведь выполнено оно в соответствии с требованиями стандарта.

Заключение:

Система информационного обеспечения жизнеспособна, если она динамична и способна быстро реагировать на изменения в жизни общества. Любая сис- 
тема нуждается в постоянном совершенствовании. Активное освоение новых технологий в сочетании с традиционными методами подготовки информационных пособий - вот что позволит качественно и оперативно обеспечивать научные разработки информацией.

Благодаря освоению новых информационных технологий и изменениям не только формы предоставления информации, но и доступа к ней трансформируются структура и многие традиционные способы работы библиотеки, возникают новые формы библиотечного обслуживания, а также новые требования к выполняемым им функциям.

Повысить качество обслуживания студентов можно лишь при объединении усилий библиотек города и их взаимодействии с библиотеками других систем и ведомств, в первую очередь государственными. Должно быть предоставление фондов более широкому кругу пользователей, которые должны открыть возможность саморегуляции потока читателей, выбора ими той библиотеки, чьи фонды и условия обслуживания наиболее соответствуют их потребностям. 


\section{3. СОВРЕМЕННЫЕ ЗАДАЧИ ВУЗОВСКОЙ БИБЛИОТЕКИ В КОН- ТЕКСТЕ КОРПОРАТИВНОЙ ДЕЯТЕЛЬНОСТИ}

Грядущее столетие еще пару десятков лет назад стали громко именовать Эрой Информации. Переход к информационному обществу сопровождается формированием принципиально иной системы информационных коммуникаций, базирующейся на переводе основного массива информации в электронную (цифровую) форму с одновременным обеспечением возможности доступа к этим данным из любого места в любое время.

Библиотеки не в состоянии конкурировать с коммерческими компаниями ни по полноте документов, ни по оперативности обновления данных, ни по уровню сервиса. Единственным неоспоримым преимуществом библиотек остается бесплатность пользования.

Дабы сохранить позиции в меняющемся мире, библиотекам предстоит во многом измениться самим и основной акцент при этом должен быть сделан на адаптацию достижений высоких технологий. Речь идет как о тотальной компьютеризации существующих библиотечных процессов, так и о предложении совершенно новых форм обслуживания при сокращении производственных затрат. Технической базой осуществления этих преобразований должны стать корпоративные библиотечные сети, обеспечивающие взаимодействие и объединение ресурсов, а также экономию усилий библиотек.

Формы взаимодействия библиотек могут быть различными, но анализ отечественного опыта и наблюдения последних лет показывают, что на первый план выдвигается корпоративная модель объединения библиотек, где каждый участник вносит свой вклад, свою долю и получает возможность пользоваться результатом усилий всего содружества, работающего на добровольной основе в рамках согласованных единых стандартов. Результатом работы подобных консорциумов могут быть: совместные информационные ресурсы, методическая документация. В процессе корпоративной работы каждый участник может реально оценить качество собственных информационных ресурсов.

Применение новых электронных продуктов в информационнобиблиотечной деятельности существенно ускоряет и повышает качественный уровень обслуживания пользователей, преобразует и видоизменяет весь комплекс существующих технологий, создает условия для реализации одного из главных принципов - принципа всеобщей доступности информации.

\section{Объединение информационных ресурсов вузовских библиотек}

В настоящее время значение вузовской библиотеки возрастает и определяется уровнем комфортности доступа к информации. В связи с нарастающим развитием информационных технологий в библиотечном деле быстрыми темпами развиваются межбиблиотечные связи. Вузовская библиотека также не осталась в стороне от новых требований времени - создания автоматизированной библиотеки, имеющей электронные ресурсы, программное обеспечение, сетевое оборудование, интернет. 
Создание и функционирование единой информационно-образовательной сферы придает подготовке специалистов новое качество, которое делает ее современной.

Автоматизация каждой библиотеки в первую очередь предполагает решение своих собственных внутрибиблиотечных проблем, таких как создание технического парка, освоение автоматизированной информационно-библиотечной системы, обучение сотрудников и, конечно же, создание собственных каталогов. Сегодня уже существуют частично или полностью автоматизированные библиотеки, т.е. имеющие электронные ресурсы, линии связи и сетевое оборудование, Интернет, программное обеспечение.

Необходимо решить организационные вопросы: создать рабочую группу по созданию региональной базы по железнодорожной тематике; определить библиотеки, участвующие в библиографической работе; создать нормативноправовую документацию и т.п.

Проект создания корпоративной сети библиотек позволит организовать работу в распределенной корпоративной системе при объединении библиотек различных типов и при использовании в библиотеках АБИС различных производителей. Опыт работы других корпоративных сетей окажет значительную помощь в области создания информационных ресурсов по железнодорожной тематике.

\section{Корпоративные продукты библиотек Росжелдора}

У библиотек железнодорожных ВУЗов Росжелдора есть некоторый опыт кооперации. Он преимущественно состоял в участии вузовских библиотек в создании сводных справочно-информационных ресурсов, а именно «Сводном электронном каталоге периодических изданий, получаемых библиотеками вузов Росжелдора» (координатор библиотека ОмГУПСа) и «Базе научных трудов ученых университетов Росжелдора» (координатор библиотека ПГУПСа), «Ежегодного выпуска аннотированного каталога внутривузовских изданий (ГОУ «УМЦ ЖДТ»).

Серьезной попыткой объединения стало обсуждение проблемы создания корпорации вузовских библиотек Росжелдора и координация деятельности по формированию библиотечно-информационных ресурсов, создание корпоративного справочно-поискового аппарата на заседании Совета директоров библиотек вузов Росжелдора от 26-28 октября 2009 г., проводимом по инициативе Федерального агентства железнодорожного транспорта в Санкт-Петербургском государственном университете путей сообщения. В ходе круглого стола участники обсудили проблему создания корпорации библиотек (единый каталог, единая полнотекстовая база) и отметили, что наибольший интерес при работе в корпоративной сети представляет электронный каталог - основная база данных библиотеки. От качества ведения электронного каталога, от того, насколько он раскрывает фонд библиотеки, его информационную наполненность, зависит качество информационного поиска и, в конечном итоге, качество обслуживания пользователей библиотеки и ее партнеров в корпоративной сети. От качества 
библиографической записи, вводимой в ЭК, зависит, воспользуются ли партнеры библиотеки по корпоративной сети этой библиографической записью или нет. Заимствование библиографической записи у библиотек-партнеров - одна из главных задач при разработке корпоративных сетей. Смысл создания корпоративной библиотечной системы - в объединении усилий.

Библиотечные консорциумы представляют собой корпорацию на основе профессиональных интересов, объединяющих большое количество информационно-библиотечных учреждений. В настоящее время практически ни одна библиотека не в состоянии в одиночку удовлетворить все информационные потребности пользователей. Максимально полное удовлетворение спроса на информацию среди пользователей специальных библиотек возможно только при соответствующем времени техническом развитии специальных библиотек и обмене информацией по современным надежным каналам связи.

Результатом такой деятельности должно стать повышение скорости и качества технологических процессов библиотек, обслуживания пользователей.

Для эффективной работы библиотек вузов железнодорожного транспорта и создания корпоративных электронных ресурсов Росжелдора Совет директоров библиотек вузов вынес рекомендации обратиться в ОАО «РЖД» по вопросу создания консорциума совместно с ЦНТБ - филиалом ОАО «РЖД».

В рамках рассмотрения вопроса по реализации совместного информационного проекта консорциума библиотек вузов Росжелдора, ЗАО «КОНЕК» предоставлял НТБ СамГУПС тестовый бесплатный доступ к зарубежным базам: OECД, PROQUEST и EMERALD. До июня 2010 года предоставлен тестовый доступ к базе данных Полпред.

Еще одним направлением, по которому прошло взаимодействие вузовских библиотек, было участие в формировании перспективных планов издания издательства «ГОУ УМЦ ЖДТ» на пятилетний период и переиздания основополагающих вузовских учебников. Библиотеки железнодорожных вузов проанализировали состояние своих учебных фондов и составили списки по дисциплинам. Ряд издательств, в частности «Лань» (СПб) и ИД «Альянс» организовали переиздания некоторых крайне необходимых для вузов учебников.

\section{Работа библиотеки в библиотечном консорциуме}

События в библиотечной жизни последних лет отчетливо демонстрируют нарастание тенденций к межведомственному объединению библиотек и к созданию межбиблиотечных консорциумов.

Цели корпоративных объединений:

Обеспечение свободного и широкого доступа всех категорий пользователей к библиотечно-информационным ресурсам.

Расширение номенклатуры услуг

Сокращение экономических и физических затрат участников корпоративных работ на создание и поддержку ЭК с использованием однократного введения библиографической записи и ее многократного использования всеми участниками и пользователями. 
Повышение квалификации персонала

Повышение рейтинга библиотеки

Получать доступ к информационным ресурсам консорциума можно двумя путями:

1. Покупать готовый продукт

2. Участвовать в создании и тогда бесплатно пользоваться информацией.

В настоящий момент НТБ СамГУПС участвует в проектах АРБИКОНА МАРС и ЭДД.

В 2005 году НТБ СамГУПС заключила договор о сотрудничестве в области развития библиотечно-информационных ресурсов Ассоциацией Российских библиотечных консорциумов (АРБИКОН).

В настоящее время в АРБИКОН входит 13 региональных библиотечных консорциумов, охватывающих значительную территорию нашей страны.

Каждый консорциум включает в себя различное количество организаций библиотечного сообщества и определяет политику доступа к своим ресурсам.

\section{Региональные библиотечные консорциумы, члены АРБИКОН}

Consensum omnium: корпоративная сеть библиотек Урала

RUSLANet: библиотечная сеть учреждений науки и образования СевероЗападного региона России

Консорциум «Черноземье»

КОРБИС (Тверь и партнеры)

Корпоративная библиотечная сеть г. Казани

Корпоративная библиотечная сеть Республики Карелия

Корпоративная сеть Московских библиотек

Межрегиональная аналитическая роспись статей

Нижнегородская корпоративная библиотечная система

Омская корпоративная библиотечная система

Открытая корпоративная библиотечная система Челябинского региона

Открытая корпоративная библиотечная система г. Новосибирска

Томский региональный библиотечный консорциум

Ярославская корпоративная библиотечная сеть

Так же в проекте МАРС участвуют библиотеки Беларусь, Украины и Казахстана.

Функционирование библиотек в рамках единого целого предполагает наличие тесных профессиональных связей между участниками, обязательное выполнение некоторых единых правил и норм, согласованность решений и действий, направленных на конечный результат. Именно согласованность действий является непременным условием эффективной деятельности корпоративной сети, основанной на правовой договорной основе.

\section{Проект МАРС}

Одним из проектов АРБИКОН является Межрегиональная Аналитичская Роспись Статей (MAPC) (http://mars.arbicon.ru). 
Проект существует с 2001 года и в настоящее время объединяет 186 библиотек различных систем и ведомств, которые общими усилиями создают сводную базу данных, содержащую полную аналитическую роспись журналов.

Сводная база данных не содержит полных текстов статей. Особенностями проекта является полная аналитическая роспись журналов, равноправие всех участников проекта, использование единых нормативных документов и открытость проекта. Любая библиотека может присоединиться к проекту, если согласна с действующими в нем правилами.

Цель - оперативное создание участниками качественного информационного ресурса аннотированной библиографической базы данных журнальных статей (1638 журналов, номеров: 62890, статей: 1199254) и предоставление сервиса поиска в информационном ресурсе и сервиса заимствования библиографических записей в базы данных организаций.

Библиотеки, участницы проекта МАРC, работают с разным программным обеспечением: ИРБИС, ORAC-R, RUSLANet, Marc. Это стало возможным при совместимости коммуникативных форматов RUSMARC, UNIMARC, USMARC

C 2003 г. Проект получает финансовую и техническую поддержку АРБИКОН. В 2005 году проект получает статус проекта АРБИКОН.

Все участники проекта пользуются единой методической документацией. Была создана методика заполнения полей, расширен рубрикатор, изменилась технология импорта и экспорта данных. Все эти изменения упростили рабочий процесс и сократили временные затраты на создание записи.

В нашем вузе успешно работают библиографы в составе корпорации «МАРС» 2005 года.

Вступление в проект состояло из нескольких этапов:

- оформление заявки на участие в проекте;

- изучение единой методической базы проекта;

- выбор и согласование перечня журналов для росписи;

- решение технических проблем;

- обучение библиографов-участников проекта.

После всех предварительных согласований, были отправлены тестовые росписи статей. Практически от всех участников проекта потребовалось:

- овладение новыми знаниями и навыками в рамках уже используемых технологий;

- наличие навыков общения по электронной почте, столь необходимых для коллектива, разделенного большими расстояниями;

- работа с различными форматами документов, программами архиваторов;

- усовершенствование технологий создания аналитического описания документа и его систематизации;

- понадобилось срочно определить перечень приоритетных для библиотеки журналов, технически организовать работу по приему записей, выбрать технологию управления информационным потоком.

«МАРС» очень удачно работает, т.к. все участники четко соблюдают жесткие требования методической документации. 
Главные принципы этой корпорации открытость, равноправие всех участников проекта, неукоснительное соблюдение общих договоренностей и ориентированность на конечного пользователя-читателя. Общими договоренностями были соблюдение сроков подготовки полной аннотированной росписи закрепленных изданий за нами, как за библиотекой-участницей, и общих правил работы при создании и обмене данными.

Для нас целью вступления в проект было облегчение работы библиографов, уменьшение нагрузки в их повседневной работе по росписи периодических изданий за счет обмена данными между участниками проекта. За 5 лет работы проекта наша библиотека ощутила реальную эффективность от корпоративной деятельности. Пользователи оперативно получают библиографическую информацию о большем круге периодических изданий, чем ранее.

Обращаясь к электронному каталогу, читатель тут же узнает - можно заказать этот журнал в нашей библиотеке или получить ту или иную статью через электронную доставку документа, для этого есть специальное поле в записи, указывающее местонахождение оригинала.

Читатели библиотеки университета имеют возможность обратиться к 6-7 тысячам новых аннотированных записей ежемесячно.

За 2009 год импорт записей составил 47355 записей, экспорт - 1210.

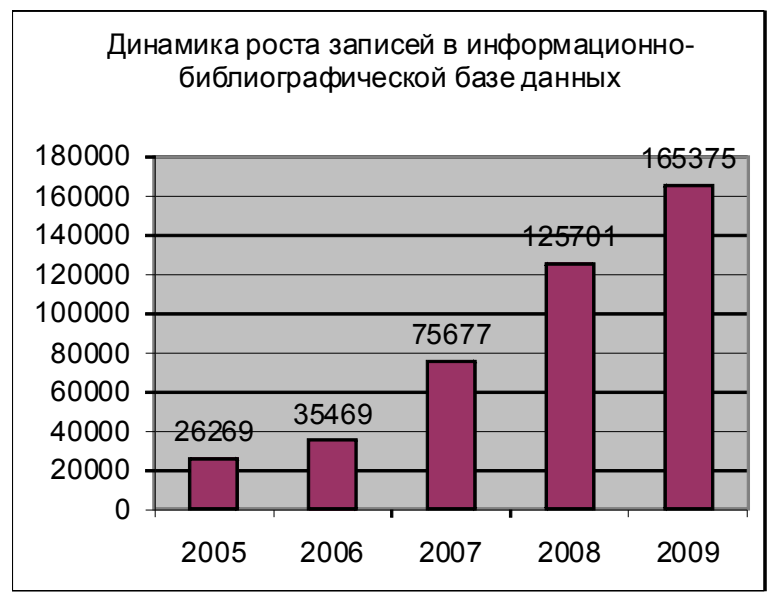

Работая в проект МАРС библиотека приняла участие в составлении проекта Рубрикатора - рубрика Транспорт - подрубрика Железнодорожный транспорт.

В проекте мы встретились со сплоченной командой неравнодушных единомышленников. Опыт работы в проекте показал: главное в любом деле - это начать его. По ходу работы выяснилось, как и что нужно делать.

Анализируя результаты совместной работы, можно убедиться , что реальная польза от сотрудничества очевидна: 
Более 60 процентов подписки на периодические издания раскрывается с помощью корпоративной базы.

Участие в проекте позволяет ознакомиться с содержанием журналов, которые не выписывает библиотека.

Информационное обслуживание пользователей стало более эффективным и качественным.

В рамках проекта каждая библиотека принимает участие в коллективном голосовании по вопросам, требующим совместного решения. В МАРСе незыблемо действуют принципы открытости. Ни одно решение, ни одно изменение ни в методики, ни в порядок не вносится без предварительного обсуждения всех участников в листе рассылки. Затем объявляется голосование. Процедура голосования и принятия решений оговорена в договоре и строго соблюдается Координационным советом.

Деятельность в рамках консорциумов требует очень много от библиотекучастников. Любая инновационная деятельность связана с изменение внутрибиблиотечных технологий, разработкой механизмов взаимодействия, с психологической готовностью к переменам и жестким выполнением всех требований, с правовым урегулированием отношений.

\section{Проект ЭДД}

На базе объединенных каталогов и организованных корпораций создается новый вид обслуживания - корпоративный сервис для читателя, пользующегося системой межбиблиотечного абонемента (МБА) и электронной доставки документа (ЭДД).

Благодаря внедрению корпоративных технологий заинтересованные библиотеки имеют возможность обеспечить высокий уровень обслуживания своих пользователей. Хорошо работающая система ЭДД является заметным вкладом в информационное обслуживание. Система обслуживания по МБА и ЭДД в корпоративном проекте решает проблемы обмена библиотечными фондами, сокращения времени на копирование и отправку копий изданий, постепенного создания архивов электронных публикаций и доступа к ним посредством телекоммуникационной сети.

В 2007 году библиотека СамГУПС присоединилась к проекту (ЭДД) электронного заказа и доставки документов на основе сводного каталога журналов (http://ill.arbicon.ru). Библиотека подписала договор о сотрудничестве в области информационных сервисов с АРБИКОН.

Технология ЭДД включает следующие основные этапы: получение заказа на копирование и ЭДД; обработка заказа, изготовление копий или их поиск электронных хранилищах; доставка копий заказчику, хранение копий. Заказ формируется на основе сведений из сводного ЭК или ЭК той же библиотеки, из которой запрашиваются издания. Изготовление копий документов для ЭДД производится с помощью процедуры копирования. Доставка копий заказчикам осуществляется в следующих режимах:

- посредством электронной почты; 
- передачей через факс;

- распечаткой на принтере с последующей передачей заказчику.

Использование ЭДД повышает полноту, оперативность и номенклатуру услуг библиотечно-информационного обслуживания пользователей за счет представления им объединенных информационных ресурсов корпоративной системы.

В условиях использования электронных документов изменяются функции вузовских библиотек, обеспечивается доступ к полнотекстовым удаленным информационным ресурсам.

Цель - создание современной службы электронного заказа и доставки копий статей за счет распределения обязанностей по обслуживанию заказов между организациями-участниками проекта. Программное обеспечение формирования заказа и доставки информации потребителю предоставляется всем участникам проекта бесплатно (программное обеспечение «Руслан» АРМ «МБА ЭДД»).

ЭДД позволяет оперативно выполнять информационные запросы пользователей и качественно повысить уровень библиотечных услуг.

Приоритетным направлением развития в библиотеки является повышение качества и ассортимента предоставляемых информационных ресурсов и сервисов для нужд образования и науки.

Не остается сомнений и в том, что объединение усилий библиотек и доступ к совместным ресурсам становится необходимым условием для дальнейшего совершенствования организации доступа потребителей к их фондам и обеспечивает существенно сокращение затрат на его обеспечение. Внедрение корпоративных технологий в библиотечную среду позволяет получить следующие преимущества:

Библиотеки получают возможность предоставления своим пользователям доступа к распределенному ЭК, включающему в себя каталог крупных библиотек.

Сокращение затрат на каталогизацию за счет сокращения дублируемой работы различных библиотек.

На базе корпоративного ЭК появляется возможность предоставить пользователям новые услуги: электронный заказ и доставку документов и расширить круг источников информации.

Подводя в самом общем плане итоги пятилетней деятельности в корпоративном проектах АРБИКОНА - МАРС и ЭДД, следует отметить, что они оказали заметное влияние на развитие информационно-библиотечной работы библиотеки вуза. Это касается:

создания корпоративных электронных ресурсов;

активизации использования библиотечных фондов и оптимизации библиотечного обслуживания пользователей через систему традиционного МБА и электронной доставки документов;

организации профессионального общения библиотечных специалистов в совещаниях и конференциях.

Наша библиотека приняла участие в конференции АРБИКОН «Практические аспекты модернизации вузовских библиотек», проводимый в СанктПетербурге в декабре 2004 года. 
Новые подходы в работе библиотек несомненно будут сопровождаться изменением теоретических представлениях о ее функциях, смещением акцентов в управлении и правовом регулировании информационной деятельностей, подготовке кадров информационных работников. Библиотечному сообществу стоит со всей серьезностью задуматься над этим сегодня, чтобы завтра библиотеки не оказались в роли третьестепенных общественных институтов.

\section{СПИСОК ИСТОЧнИкОВ}

1. Зеленина Г. Н. Технология создания сводного каталога подписки участников проекта МАРС / Г. Н. Зеленина, А. В. Данилов, П. А. Вотинцев // Научные и технические библиотеки. - 2006. - № 10. - c. 39-44.

2. Коряковиева Н. А. Роль библиотеки в формировании корпоративной идентичности вуза / Н.А. Коряковиева. - (Библиотечноинформационная деятельность: теория и практика) // Научные и технические библиотеки. - 2009. - № 7. - с. 5-11

3. Лепий, Ольга. Как работается с «МАРСом» / Ольга Лепий. - (Новые информационные технологии). - (В рамках проекта) // Библиотека. 2007. - № 9. - c. 28-29

4. Нохрина В. А. Корпоративное взаимодействие библиотек / B. А. Нохрина. - (Urbi et orbi). - (Граду и миру) // Мир библиографии. 2007. - №2. - c. 1 .

5. Племнек, Александр. Проекты АРБИКОН доказали свою устойчивость и стабильность / Александр Племнек. - (Информационные технологии. Проблемы автоматизации) // Библиотека. - 2007. - № 3. c. $15-18$

6. Решетник Н. Н. Современная библиотека в контексте корпоративной деятельности [Электронный ресурс] / Н. Н. Решетник. - Режим доступа: http://library.uipa.kharkov.ua/library

7. Степанов В. К. Информационное общество и библиотеки // Библиотечное дело - 2000: проблемы формирования открытого информационного общества: Тез. Докл. Пятой международной конферениии. Москва, 25-26 апреля, 2000 г. - М., 2000. - Ч.2. - с. 31.

8. Шрайберг Я. Л. Корпоративные и национальные проекты Открытого доступа / Я. Л. Шрайберг, А. И. Земсков. - (Открытый доступ и открытые архивы информации) // Научные и технические библиотеки. 2008. - № 8. - c. 5-23 


\section{4. СИСТЕМНИЙ ПІДХІД ДО СТВОРЕННЯ ЕЛЕКТРОННОЇ БІБЛІОТЕ- КИ В ІНФОРМАЦІЙНОМУ СЕРЕДОВИЩІ ВНЗ}

Сучасне суспільство визначається як інформаційне, в якому найважливішими сферами соціальної активності є освіта, науково-технічні знання, сфера масових комунікацій.

Це особливо актуально для України, яка визначила своїм пріоритетом створення необхідних умов для забезпечення громадян і суспільства своєчасною, повною та достовірною інформацією шляхом широкого використання інформаційних технологій (IT). Відповідні пріоритети закладені також у Законі України «Про Основні засади розвитку інформаційного суспільства в Україні на 20072015 роки», однією з головних умов успішної реалізації якого є забезпечення навчання, виховання, професійної підготовки людини для роботи в інформаційному суспільстві. Для цього необхідно: розвивати національний науково-освітній простір, який грунтуватиметься на об'єднанні різних національних багатоцільових інформаційно-комунікаційних систем; розробити методологічне забезпечення використання комп'ютерних мультимедійних технологій тощо [1].

Значущою інтегральною ланкою такого суспільства $є$ бібліотеки, які акумулюють, обробляють та поширюють у часі й просторі документовані знання. Стрімке збільшення обсягів електронних ресурсів у структурі інформаційних ресурсів (IP) сучасних бібліотек потребує вивчення та узагальнення теоретичних розробок, практичного досвіду, набутого в процесі створення та розвитку електронної бібліотеки (ЕБ).

У Законі України «Про національну програму інформатизації» визначається нова роль бібліотеки та їі завдання в процесі формування інформаційного суспільства [2].

Частина науковців під інформаційним суспільством розуміє ступінь розвитку інформаційних та телекомунікаційних технологій (IКТ) і наголошують на технологічному аспекті проблеми. Інша частина інформаційним вважає суспільство, побудоване на знаннях, в якому головними продуктами виробництва $\epsilon$ інформація і знання.

Деякі вчені до інформаційного суспільство відносять суспільство знань, в якому під теоретичним знанням розуміється знання абстрактне, узагальнене, кодифіковане і зафіксоване на матеріальних носіях.

Таким чином, існує декілька підходів до формування інформаційного суспільства: інформаційний і знаннєвий, в основі яких лежить або інформація, або знання. Пархоменко В. О. пропонує новий підхід до розуміння сутності сучасного суспільства як інформаційно-знаннєвого [7].

Перехід до інформаційно-знаннєвого суспільства ставить перед науковцями і практиками ряд питань, одне з яких визначає, що формування та розвиток такого суспільства здійснюється в нерозривній єдності з розвитком ІКТ та створенням IP.

Інтеграція IP передбачає об'єднання цих ресурсів з метою використання різної інформації зі збереженням ііі властивостей, особливостей подання і можливо- 
стей маніпулювання нею. При цьому об'єднання ресурсів не обов'язково повинне здійснюватися фізично: воно може бути віртуальним і забезпечувати користувачу сприйняття доступної інформації як єдиного інформаційного простору.

Бібліотека інформаційного суспільства - це органічна частина людського співтовариства, що слугує кожній особі, допомогає їй удосконалюватися. Ціннісні орієнтири сучасної бібліотеки виявляються не лише у виборі і формуванні фонду, адекватного потребам читачів, а й у визначенні пріоритетних читацьких груп; основних напрямів діяльності; гармонізації технології у всіх бібліотечних циклах; узгодженні бібліографічних, класифікаційних стандартів і форматів із стандартами роботи в мережі та стандартами міжнародних бібліотечних інститутів як засобів, що сприятимуть кооперуванню і взаємодії з іншими установами, зокрема освітніми; вільному орієнтуванню читачів у ресурсах світових мереж; їх освітній роботі та самовдосконаленню [8].

Питанням сучасних бібліотек присвятили свої праці: О. В. Баркова, Г. А. Василенко, К. В. Вигурський, М. Р. Когаловський, Б. А. Новіков, Р. С. Гиляревський, А. І. Чугунова, С. І. Паринов, Я. Л. Шрайберг. Проте аналіз як вказаних, так і інших наукових праць засвідчив, що в них розглянуті лише окремі аспекти роботи бібліотек у галузі використання IКT, зокрема $з$ електронними ресурсами.

Сорбонська декларація від 25 травня 1998 року підкреслила центральну роль ВНЗ у розвитку європейських культурних цінностей, коли їх незалежність і автономія дають впевненість у тому, що системи вищої освіти і наукових досліджень будуть адаптуватися до безперервних змін у суспільстві і до необхідності розвитку наукових знань. Приєднання нашої країни до Болонського процесу відкриває можливості здійснення структурних перетворень вищої освіти за узгодженою системою критеріїв, стандартів і характеристик, що дозволить Україні стати повноправним членом європейського освітнього і наукового простору. Реформування вищої освіти у світлі Болонського процесу, безумовно, стосується всіх сторін діяльності ВНЗ, у тому числі і бібліотечного обслуговування учасників процесу навчання.

Сьогодні друковані видання, незважаючи на бурхливий розвиток IT, залишаються одним 3 пріоритетних засобів отримання знань. Бібліотека в силу обставин, що складаються у сфері освітніх послуг, повинна забезпечувати навчальний процес літературою, згідно з вимогами Міністерства освіти і науки України у співвідношенні один підручник на два студенти та науково-дослідну роботу науковців як друкованими, так і електронними документами наукової складової, оскільки підписання Україною Болонської конвенції висуває певні вимоги до ВНЗ щодо розвитку науково-технічної діяльності та її результативності, а отже, і до вузівських бібліотек з комплектування фонду науковими виданнями та іншими IP.

Створення єдиного освітнього простору, який містить як традиційні IP (бібліотеки, книжки, підручники, наукові журнали тощо), так і їх електронні аналоги, а також спеціалізовані наукові та освітні портали, сайти наукових організаційні закладів освіти - головне інноваційне освітянське завдання сьогодення. 
А найважливішою складовою єдиного освітнього середовища є електронні ресурси (ЕР).

Закон України «Про бібліотеки і бібліотечну справу» визначає бібліотечні ресурси як упорядковані бібліотечні фонди документів на різних носіях інформації; бази даних; мережні інформаційні ресурси; довідково-пошуковий апарат; матеріально-технічні засоби опрацювання, зберігання та передачі інформації [4].

Бібліотека як соціальний інститут покликана виконувати завдання, покладені на неї суспільством і державою, а саме - збирання та зберігання джерел інформації і надання до них вільного, комфортного і швидкого доступу. Наскільки iï інформаційний простір та нові методи організації доступу і навігації на базі ІКТ відповідають запитам користувачів, настільки успішною стає робота BH3.

Сьогодні, коли підвищилася соціальна та інформаційна роль бібліотек у сучасній освітній діяльності, виникає необхідність формування нових методів організації інформаційного простору бібліотеки ВНЗ, яка реалізується на базі комп'ютерних технологій з метою підвищення рівня інформатизації навчального закладу.

Нормативними документами для впровадження інноваційних технологій у роботу бібліотеки ВНЗ $є$ :

- Указ Президента України «Про невідкладні заходи щодо забезпечення функціонування та розвитку освіти в Україні» від 04.07.2005 №101312005;

- Наказ МОН «Про основні завдання вищих навчальних закладів України» на 2008/2009 навчальний рік від 21.04.2008 №349;

- Наказ МОН «Про основні завдання вищих навчальних закладів України» на 2009/2010 навчальний рік від 26.05.2009 №437;

- Державна програма «Інформаційні та комунікаційні технології в освіті і науці» на 2006-2010 роки;

- Постанова Верховної Ради України «Про затвердження завдань Національної програми інформатизації на 2006-2008 роки» (розділ «Інформатизація освіти, науки і культури»).

Перед бібліотеками ВНЗ постає завдання комплектування фондів спеціалізованими електронними документами та збереження умов їх використання. Бібліотеки, в тому числі і ВНЗ, ведуть роботу зі створення електронних IP: формують електронні каталоги, картотеки наукових праць, створюють архіви повнотекстових електронних документів.

Згідно із Законом України «Про електронні документи та електронний документообіг» електронний документ - це документ, інформація в якому зафіксована у вигляді електронних даних, включаючи обов'язкові реквізити документа. Електронний документ може бути створений, переданий, збережений i перетворений електронними засобами у візуальну форму. Візуальною формою подання електронного документа $\epsilon$ відображення інформації, яку він містить, електронними засобами (комп'ютерне обладнання і програмне забезпечення) або на папері (способом переведення іiї у друковану форму за допомогою ком- 
п'ютерного обладнання) у формі, придатній для сприйняття його змісту людиною [3].

Електронна (цифрова бібліотека) - бібліотека, в якій усі документи зберігаються в цифрових форматах і доступні для роботи з комп'ютером. Фонди ЕБ, як текстові, так і звукові, рухомі, графічні, можуть бути ефективно використані при підготовці навчально-методичних матеріалів нового покоління [10].

Сучасна бібліотека $є$ «гібридною бібліотекою», у якій інтегруються елементи традиційної та електронної бібліотеки.

Під «гібридною» розуміють бібліотеку, яка має у своєму фонді документи на різних носіях, розміщених у різних місцях (на основному сервері, на віддалених серверах, на національних і групових серверах) і яка пропонує своїм користувачам інтегрований доступ до всього фонду відразу, а не частинами [5].

Термін «гібридна бібліотека» використовують для означення проміжної ланки на шляху повного переходу до ЕБ. У гібридній бібліотеці співвідношення між друкованою та цифровою метаінформацією дедалі схиляється у бік цифрової.

Серед переваг ЕБ слід назвати зменшення обсягів інформації, що зберігається; нижчий рівень зношуваності матеріалів; здатність одночасно надавати кільком користувачам одну й ту саму інформацію; швидкість пошуку потрібної інформації за кількома критеріями; доступ до електронного варіанту видання, друкований примірник якого знаходиться в користуванні; доступ до раритетних екземплярів видань; можливість доступу до матеріалів 3 місць, які знаходяться поза межами бібліотеки.

Сучасні ЕБ - це системи збирання, збереження, обробки і видачі інформації, які підтримують ЕР різного типу і працюють у глобальних інформаційних мережах передачі даних [6].

Інформаційні ресурси ЕБ ВНЗ, як правило, складаються з декількох частин, в яких переважають навчальна і наукова. До першої входять електронні підручники, навчальні посібники та навчально-методичні розробки, спрямовані на опанування студентами навчального матеріалу. Основу другої частини ЕБ складають електронні книги, автореферати дисертацій і наукові статті, які забезпечують розширення можливостей для навчального процесу та впровадження наукових досліджень.

Основними функціями, які реалізовані ЕБ, є: розкриття власних фондів, поповнення фондів ЕБ шляхом отримання повнотекстових документів, пошук у світовому документованому потоці та розширення структури іiі фонду, можливість реалізації паралельного опрацювання ЕР мережі Інтернет шляхом створення метаданих у вигляді довідника.

Основна мета створення ЕБ - створення інформаційної системи (IC), в якій документи зберігаються і можуть використовуватися в електронній формі. Програмні засоби при цьому забезпечують єдиний інтерфейс доступу до електронних документів, які містять тексти та зображення.

Функціональними ознаками ЕБ як IC, так і організаційної структури є:

- фонд електронних документів;

- кероване середовище, що базується на мережевих технологіях; 
- пошуковий апарат з механізмом інтелектуального пошуку;

- наявність користувачів;

- онлайновий режим доступу до документа багатьох користувачів;

- вільний або ліцензований доступ до IP;

- функціонування в певному правовому полі.

На сучасному етапі застосування IT у галузі вищої освіти існує нагальна потреба у реалізації системного підходу. Це, насамперед, усвідомлення того, що ВНЗ являє собою систему, складену з частин, кожна з яких має свої власні інтереси. Тому досягти загальної мети можна лише тоді, коли розглядати ВНЗ як єдину систему, намагаючись зрозуміти й оцінити взаємодію всіх їі частин та об'єднати їх на такій основі, яка б дозволила навчальному закладу в цілому ефективно виконувати поставлені завдання [9].

При цьому важливо правильно визначити основні цілі і засоби їх досягнення. Мається на увазі, що IC повинна виконувати важливу допоміжну роль у виконанні головного завдання ВНЗ - підвищення якості підготовки студентів шляхом розробки і впровадження системи управління якістю на основі принципів TQM і вимог Міжнародних стандартів ISO серії 9000:2000.

Така IC сприятиме ефективному впровадженню системи якості і забезпечуватиме інформаційну підтримку управління основними видами діяльності ВНЗ, його головними процесами. IC ВНЗ повинна розглядатись як сукупність апаратних i програмних засобів, баз даних та знань, комплексу документів системи якості, а також кваліфікованого персоналу, здатного обслуговувати й ефективно користуватися системою. Крім забезпечення високої якості навчання, IC має бути зорієнтована на підвищення результативності наукової компоненти діяльності ВНЗ.

IC повинна мати ієрархічну модульну структуру, однією з підсистем якої є автоматизована система управління знаннями (АСУЗ).

АСУЗ має забезпечити генерацію нових знань. IIÏ основне спрямування - залучення викладацького складу і студентів до інноваційного процесу розвитку науки, а також вирішенню складних нетривіальних проблем, що виникають у практичній діяльності підприємств і організацій.

Важливою є роль сучасних IT для збирання й аналізу інформації про знання у певних наукових напрямах. Ці знання містяться у документах, досвіді, уміннях, навичках співробітників і визначають подальший науковий розвиток і безпосередньо впливають на стратегічний розвиток самого ВНЗ. Це не просто накопичення загального масиву знань у певній сфері діяльності. Структуризація знань через опис набору умінь, навичок, досвіду, поєднана з виявленням найкращих фахівців - носіїв унікальних знань, дає змогу отримувати й генерувати нові знання для вирішення все нових практичних і теоретичних завдань, що постають перед суспільством.

Існують дві основні стратегії управління знаннями, а саме: кодифікація і персоніфікація. Стратегія кодифікації базується на формуванні масиву знань і відповідних довідково-пошукових системах без прив'язування їх до фахівців, які їх генерували. Це дає можливість іншим спеціалістам повторно використовувати накопичені знання для вирішення таких завдань. 
Іншою стратегією управління знаннями $є$ стратегія персоніфікації. Вона базується на створенні баз даних щодо фахівців - носіїв унікальних знань. Нові знання генеруються під час особистих зустрічей, обговорень, мозкових штурмів фахівців, а також через застосування сучасних IКТ.

Порівняння описаних стратегій з урахуванням специфіки ВНЗ дозволяє зробити висновок про те, що ВНЗ доцільно будувати свою систему управління знаннями на стратегії персоніфікації. Це пов'язано з тим, що ВНЗ, зазвичай, обмежені у ресурсах, а стратегія кодифікації вимагає серйозних вкладень у розвиток і підтримку IC.

Діяльність ВНЗ тісно пов'язана 3 використанням висококваліфікованого професорсько-викладацького складу, певна частина якого $є$ носіями унікальних знань; у ВНЗ, як правило, проводяться пілотні наукові дослідження, які вимагають пошуку і прийняття нетривіальних наукових рішень; у процесі навчання виявляється здібна творча молодь, яка у подальшому може стати цінним поповненням бази даних щодо носіїв знань; розвиток ІКТ спрощує і здешевлює організацію обміну думками фахівців для генерації нових знань.

У той же час не можна недооцінювати роль стратегії управління знаннями на основі методу кодифікації. Особливо, якщо мова йде про створення ЕБ як інструменту для вирішення широкого спектру завдань: забезпечення навчального процесу електронними підручниками, методичними, лекційними матеріалами, тестовими завданнями, інформаційно-пошуковими системами, електронною картотекою, іншими спеціалізованими програмними продуктами.

Це дозволить створити так зване «віртуальне навчальне середовище», яке, в свою чергу, відповідатиме світовій тенденції у сфері вищої освіти щодо підвищення ролі самого студента в процесі навчання. Таким чином, студент матиме можливість отримувати знання незалежно від місця та часу, самостійно контролювати і визначати теми, обсяги і навіть зміст навчання.

Для підвищення ефективності наукової праці студентів та науковопедагогічних працівників необхідно ввести оперативний пошук та облік ресурсів і забезпечити об'єктивний аналіз та оцінку результатів досліджень. Для цього доцільно впровадити автоматизоване місце науковця, що являє собою програмно-технічний комплекс автоматизованого доступу користувача до корпоративної бази даних ВНЗ, та відповідного його правам набору інформаційних служб через Інтранет i/або Інтернет-мережу для автоматизації виконання ним своїх професійних обов'язків.

Отже, бібліотеки стають виробниками власних електронних IP. На базі масивів бібліографічної, реферативної, аналітичної інформації формуються різноманітні бібліотечні інформаційні продукти. Здійснюються роботи 3 оцифровування першоджерел 3 бібліотечних фондів та формування колекцій електронних документів.

Вагомою складовою документно-інформаційного ресурсу сучасної бібліотеки стають електронні IP, відомості про які мають бути введені до бібліотечних інформаційно-пошукових систем.

Існуючі ЕБ фактично є копіями класичних бібліотек за своїми функціями: 
каталоги, текстові, аудіо- та відеоматеріали - усе це, звичайно, зберігається на електронних носіях інформації. Інакше кажучи, це електронні бібліотечні колекції, які можна логічно визначити як набір критеріїв для вибору ресурсів 3 розширеного інформаційного простору.

Що ж до ЕБ, то серед ВНЗ було поширене уявлення про те, що така бібліотека - це, по суті, автоматизований пошук літератури за допомогою електронного каталогу, а також перехід бібліотечного фонду на електронну форму.

Зрозуміло, що матеріальні витрати на реалізацію такого підходу не відповідають основним цілям ВНЗ, оскільки мало що дають для удосконалення навчального процесу і наукової діяльності.

Таким чином, ЕБ потрібно розглядати як комплекс IP, програмно-технічних та телекомунікаційних засобів, мережевих онлайнових IC, організаційних структур та IT, який спрямований на багатоаспектне задоволення різноманітних інформаційних потреб споживачів у формуванні систематизованих електронних IP, їх збереженні та підтримці в активному стані; організовує дистанційний доступ до документів, інформації та систематизованого знання і здійснює та розширює основні сервіси традиційної бібліотеки в електронному середовищі.

Отже, слід підкреслити, що вимоги сучасності до науково-інформаційного забезпечення освітян потребують кардинального переосмислення основ бібліотечної справи та створення нової парадигми діяльності бібліотечноінформаційних інституцій та спрямованості на наукоємні технології: процеси формування бібліографічної інформації, реферування наукової літератури, підготовка оглядово-аналітичних і прогностичних матеріалів для керівного складу університету та науково-педагогічних працівників.

\section{СПИСОК ДЖЕРЕЛ}

1. Закон Украӥни «Про основні засади розвитку інформаційного суспільства в Украӥні на 2007-2015 роки» // Відомості Верховної Ради Украӥни $($ ВВР). - 2007. - №12. - c. 102-109.

2. Закон України «Про Національну програму інформатизації»// Відомості Верховної Ради України (ВВР). - 1998. - № 27-28. - c.181

3. Закон Украӥни «Про електронні документи та електронний документообіг» // Урядовий кур'єр. - 2003. - № 119. - с.1-6.

4. Закон України «Про бібліотеки $і$ бібліотечну справу» // Відомості Верховної Ради Украӥни (ВВР). - 1995. - №7. - с. 45.

5. Барбер Н. А Возможные решения для «гибридных» библиотек // Библиотеки и ассоциации в меняющемся мире: новые технологии и новые формы сотрудничества: 8-я Междунар. конф. «Крым 2001»: Материаль конф. - 2001. - T.1. - с. 231-232. - [Електронний ресурс]. - Режим достуny: http://linksdir.com.ua

6. Кудим К. А., Проскудина Г. Ю., Резниченко В. А. Сравнительный анализ функииональных возможностей систем электронных библиотек // Проблемы программирования. - 2007. - № 4. - с. 32-48. - [Електрон- 
ний ресурс]. - Режим достуny: http://eprints.isofts.kiev.ua

7. Пархоменко В. О. Зміна поглядів на наповнення змісту терміна «Інформаційне суспільство» // Проблеми розвитку інформаційного суспільства: Матеріали Міжнар. форуму. Львів. - 2009. - с. 223-232.

8. Свобода А. Бібліотеки інформаційного суспільства: ичннісні орієнтири діяльності // Бібл. вісн. - 2008. - № 6. - с. 29-33.

9. Основи інформаційних систем: Навч. посібник. / В.Ф. Ситник, Т. А. Писаревська, Н. В. Срьоміна, О. С. Краєва - Вид. 2-ге, перероб. $i$ don. - K.: KHEУ. $-2001 .-420$ c.

10.Пелагеша Н. Європейська цифрова бібліотека: проект створення // Бібл. вісн. - 2008. - №5. - с. 3-8. 


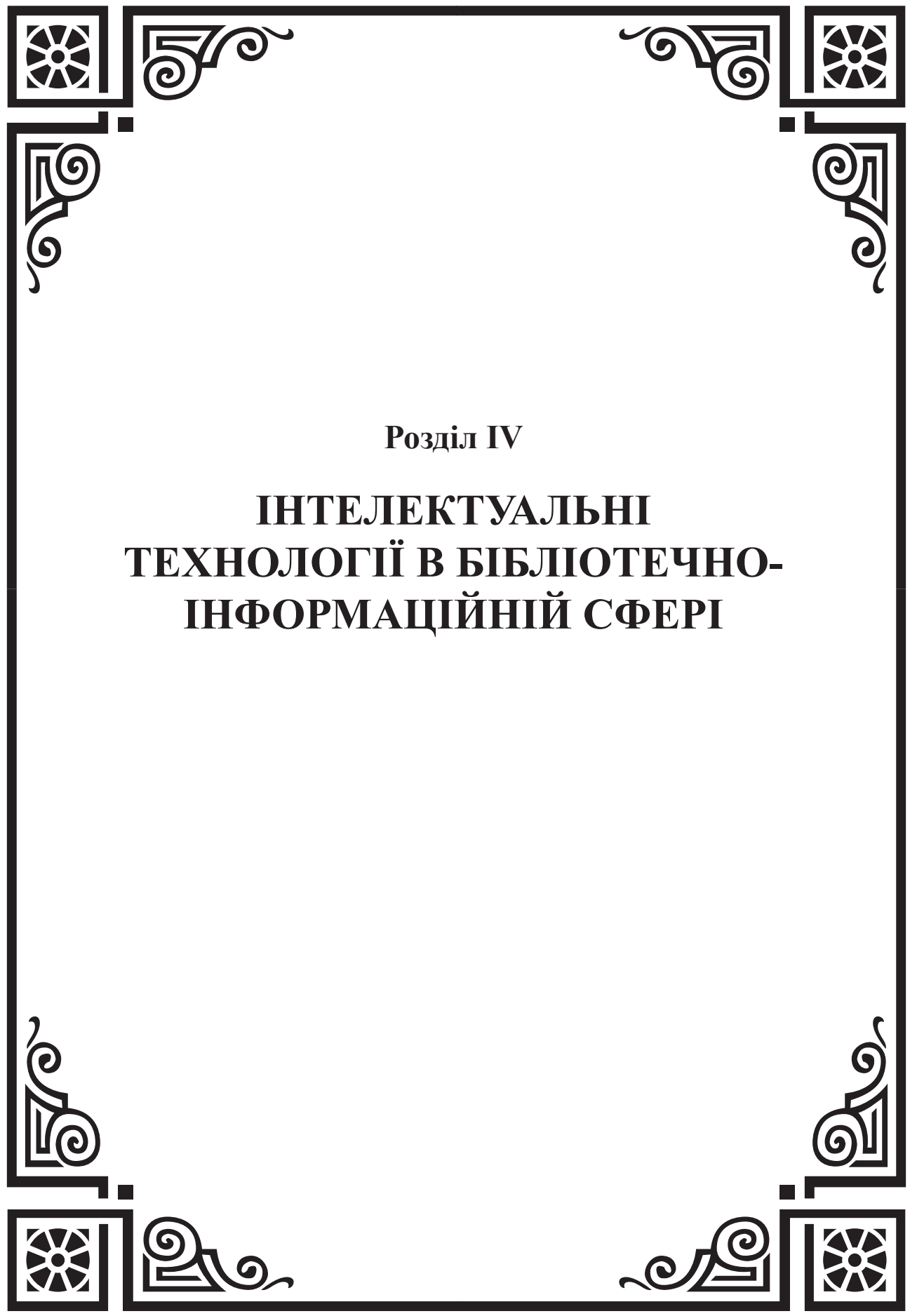




\section{1. БІБЛІОМЕТРИЧНІ ДОСЛІДЖЕННЯ ЯК АНАЛІТИЧНИЙ ІН- СТРУМЕНТ ОПТИМІЗАЦІЇ НАУКОВОЇ РОБОТИ ВНЗ}

Ідея розбудови суспільства, яке засноване на знаннях, може успішно реалізуватися лише за умови створення якісно нових систем, які продукують наукові знання. Брак знань, лакуни в освіті, нездатність суспільства продукувати і використовувати знання у зростаючих масштабах роблять його неконкурентоспроможним у світовому змаганні, відтискуючи на узбіччя цивілізації. Розвиток будь-якої країни нині залежить від можливостей іії інтелектуального потенціалу, темпів його нарощення, ефективності та мобільності використання [7].

Засади розвитку світової науки, яка стала реальністю формулюються і оголошуються на форумах і зустрічах європейського і світового рівня. Створюються спеціалізовані системи індикаторів для спостереження за розвитком інноваційного процесу на світовому і загальноєвропейському рівні, до яких Україні ще важко адаптуватися. Однак стратегічна мета інтеграції у європейський науковий простір потребує залучення вітчизняної науки до апарату оцінки результативності досліджень, що вже одержав визнання у світі.

Академік В. І. Вернадський, був одним із перших учених, хто чітко вказав на величезну роль, яку покликана відіграти розробка проблем, що входять нині у поняття «наукознавство». Відмічаючи швидке зростання обсягу наукової інформації («матеріалів науки»), він вказував, що вивчення цього процесу часто $\epsilon$ «єдиною формою критичної оцінки, яка дозволяє відрізняти цінне і постійне у величезному матеріалі цього роду, створюваному людською думкою». [1]

Вартість наукових праць зростає, витрати на науковий процес збільшуються доволі швидкими темпами. Пошук критеріїв об’єктивної оцінки якості праці вченого - одна з найважливіших проблем у взаєминах науки і суспільства, стосунках усередині наукової спільноти, а також у фінансування наукових досліджень. Найпростішим критерієм такої оцінки є кількість опублікованих праць, однак недоліки цього критерію очевидні. Один із найбільших фахівців у галузі наукометрії Д. Прайс зробив із дослідження, проведеного у Великій Британії стосовно використання наукових журналів у Лондонській науковій бібліотеці, висновок: «Наукові журнали існують для того, щоб публікуватися в них, а не для того щоб їх читати». Кількість публікацій скоріш відображає критерії ставлення дослідника до якості своєї наукової продукції, аніж ступінь його впливу на світову науку.

У багатьох країнах світу для оцінки рівня розвитку науки використовують три групи показників:

-статистичні показники розвитку науки (витрати на дослідження і розробки, чисельність наукового персоналу тощо);

- патентна статистика;

-бібліометричні показники: кількість наукових публікацій, їх цитування та ін.

Якщо статистичні показники розвитку науки і патентна статистика відображають першу стадію інноваційного процесу, то показники третьої групи - бібліометричні - відбивають ступінь активності і продуктивності фундаменталь- 
них та прикладних досліджень у країні, їх внесок у розвиток наукового знання. Таким чином, одним із підходів до вивчення науки може бути бібліометричний.

У фаховій літературі майже, як синоніми, використовуються дефініції «наукометрія», «бібліометрія». У традиційних енциклопедичних виданнях визначення наукометрії наступне: «Наукометрия - область науковедения, занимающаяся статистическими исследованиями структуры и динамики массивов и потоков научной информации.» Поняття «бібліометрія» у «Википедии» подається так «Библиоме́трия - применение математических и статистических методов к изучению книг, периодических изданий и проч.»

Кількісні методи давно по праву увійшли у практику різних досліджень. Науковці вважають, що один із фундаментальних принципів сучасної науки полягає у тому, що явища неможливо вважати зрозумілими до тих пір поки вони не описані через кількісні характеристики. У багатьох галузях діяльності дослідники проводять вимірювання, аналіз і оцінку різноманітних властивостей і взаємодії великих потоків різнорідних або однорідних об'єктів. Тривалий час кількісні методи вивчення потоків документальної інформації у бібліотечній галузі широко застосовувались у зарубіжних країнах, в нашій країні вони практично були відсутні. За останні роки ситуація змінилась: дослідники активно почали вивчати кількісні характеристики документних потоків методом, який отримав назву «бібліометрія».

Метод бібліометричного аналізу, пов'язаний із кількісним вивченням документних потоків, отримав широке розповсюдження у другій половині XX ст., хоча окремі роботи в галузі бібліометрії з'явилися значно раніше. У 1960-1970 роки бібліометрія отримала статус самостійного наукового напрямку. Теоретичну основу для наступних бібліометричних досліджень заклали роботи С. Бредфорда, А. Лотки, Г. Ципфа. Вперше термін «бібліометрія» був вживаний у 1969 році англійським вченим А. Прітчардом, який запропонував замінити ним термін «статистична бібліографія». Він визначав бібліометрію як науковий напрямок або дисципліну, яка кількісними методами вивчає процеси наукової комунікації шляхом вимірювання і аналізу різноманітних аспектів письмових документів. Однак, вчені вважають його доволі розмитим, не чітким, таким, що потребує доповнень і роз'яснень. Дослідники пропонують різні дефініції бібліометрії: «бібліометрія - комплекс кількісних методів вивчення масивів наукових документів» (О. І. Воверене); «бібліометрія - розділ бібліографознавства, який вивчає статистичними методами особливості формування структуру і динаміку документально-інформаційних потоків на основі бібліографічної інформації» (А. Н. Дівінський); «кількісний аналіз бібліографічних характеристик визначеної частини літератури» (Д. Хокінг); «застосування математичних методів до бібліографічнох, інформаційної та бібліотечної діяльності» (Д. Шмідмейер); «комплекс математичних і статистичних методів, які застосовуються у бібліотекознавстві для вивчення і оптимізації наукових документів і бібліотечних мереж» (М. Боніц) та багато інших.

Не зважаючи на те, що до теперішнього часу не існує єдиного термінологічного підходу до даного напрямку уся бібліометрія побудована на аналізі бібліо- 
графічних даних публікацій, таких як заголовок, автор, назва книги, збірника або журналу, країна та ін., тобто про бібліометрію можна говорити як про науковий напрямок, який грунтується на методах кількісного аналізу бібліографічних характеристик документів і дає основу для їх якісної оцінки.

Стрімке нарощування та зміна видів інформаційних ресурсів суспільства виявило потребу в отриманні нового знання якісно новими засобами. У рамках бібліометричних досліджень почали розроблятися нові шляхи і методики аналізу документальних потоків, а також нові напрямки їх використання. У вересні 1993 року у Берліні у рамках Міжнародної конференції із бібліометрії/наукометрії було засноване Міжнародне товариство із наукометрії та інфометрії.

До теперішнього часу бібліометрією накопичений значний емпіричний матеріал, а різноманітним іiї аспектам присвячена велика кількість публікацій. За деякими даними у різних наукових виданнях цитується більше 16 тис. публікацій, у яках описані результати, отримані з використанням бібліомеметричного аналізу. У багатьох університетах світу вводиться практика підготовки і захисту магістерських і докторських дисертацій в галузі бібліометрії. Однак, на сучасному етапі вважати бібліометрію сформованою не можна. Не існує єдиного бібліометричного підходу до методики аналізу документальних потоків у різноманітних сферах які б успішно поєднували прості і структурні методи бібліометрії. Бібліометричні дослідження, в тому числі у нашій країні, здійснюються, в основному, стосовно точних наук, дослідження ж потоків у суспільних і гуманітарних науках практично відсутні.

3 кінця 90-х років проблема створення високоефективної системи інформаційного забезпечення фундаментальної і прикладної науки вирішується впровадженням у роботу наукових бібліотек нових інформаційних технологій, при цьому останні трансформують також традиційні форми інформаційнобібліографічної діяльності. Безперечно інформаційна робота є невід'ємною частиною наукового процесу, який передбачає постійне звертання ученого до різноманітних баз даних. Активна взаємодія ученого і бібліотеки - одна з умов максимально повного інформаційного супроводу наукових робіт.

Використання наукометричних та бібліометричних БД не є прерогативою лише менеджмента науки. Іншою практичною площиною їх застосування стає бібліотечна справа.

Наукометрія і бібліометрія, як якісно нові форми розвитку аналітикосинтетичної обробки документів, спрямовані на вирішення питань найбільш раціонального вибору ефективної інформації, методик ії оцінки та ефективних шляхів дослідження, привертає все більшу увагу теоретиків і практиків бібліотекознавства. Сучасні умови функціонування вітчизняного бібліотечного інституту обумовлюються важливістю проблеми вироблення обгрунтованої, виваженої і ефективної державної політики у галузі бібліотечної справи. Актуальність проблеми полягає у тому, що наукометрія і бібліометрія - не лише теоретичні дисципліни. Вони знаходять практичне застосування в управлінні бібліотеками, інформаційними фондами, в оцінці якості журнальних публікацій тощо. Дослідження в галузі наукометрії і бібліометрії необхідні у зв'язку із їх величезною 
значимістю не лише для бібліотечної діяльності, але й для визначення наукової політики в цілому. Тому особливу увагу слід приділити широкому застосуванню методів бібліометрії, враховуючи те, що даний процес відноситься до категорії загальнонаукових.

У бібліометрії використовується ряд методів дослідження: аналіз цитування, аналіз реферативних журналів; аналіз кількісних характеристик первинних документів; кількісний аналіз публікацій окремих авторів та їх цитування; кількісний аналіз публікацій учених окремих країн і держав, а також окремих наукових колективів; теоретичні питання, у тому числі дослідження закономірностей росту, старіння і рангового розподілу наукових документів; контент-аналіз документів; інші питання, пов'язані з розповсюдженням наукових документів.

Раннім інструментарієм, який використовувався у бібліометричних (наукометричних) дослідженнях, були бібліографічні покажчики або першоджерела, як правило, періодичні видання. Сьогодні джерелами інформації можуть бути різні електронні носії (бази даних на CD-ROM, DVD та доступні через Інтернет). У залежності від способів і видів представлення даних у них, можна отримувати різну наукометричну інформацію.

Цитат-аналіз - один із напрямків у накометрії, який дозволяє виявляти тенденції розвитку і стану науки, вивчати міжособистісні стосунки - інформаційні зв'язки між ученими, тісно пов'язаний із іменем Ю. Гарфілда, який висунув ідею про особливу інформаційну мову - мову бібліографічних посилань. Саме ним були викладені основні положення і принципи теорії обліку, аналізу і використання цитування. Практичне застосування ці ідеї знайшли у покажчиках цитованої літератури (Science Citation Index, скорочено SCI), які регулярно виходять 31963 року у Інституті наукової інформації (Institute of Science Information, скорочено ISI), ідейним керівником i засновником якого $\epsilon$ Ю. Гарфілд. 31992 року фірма ISI - корпорація Thomson Reuters випускає понад 70 різноманітних інформаційних продуктів, які стали багатим джерелом для наукометричних досліджень.

Увага учених до досліджень наукового цитування пояснюється ти, що це ефективний спосіб вивчити комунікацію у професійній спільноті, дисциплінарну структуру науки, механізми народження нового знання. Цитування надає досліднику хоча і невичерпні, зате об'єктивні показники. Неповнота даних цитування обумовлена тим, що немало ідей черпаються у неформальному спілкуванні учених, в усних диспутах на конференціях і симпозіумах, або при особистому контакті спеціалістів. При бібліометричному і наукометричному ж аналізі доводиться задовольнятися лише вивченням опублікованих праць, відповідно, з указаними в них джерелами, які сприяли створенню нового наукового матеріалу. Інше припущення від якого відштовхуються дослідники науки при використанні існуючих і розробці нових індексів наукового цитування, полягає у тому, що найбільш відчутно процес наукової комунікації представлений у журнальних публікація. Саме періодичні видання відомі своєю оперативністю у відображенні нових наукових тенденцій. Хоча, відповідно до досліджень В. Генцеля та У. Шьопфліна (W. Glanzel, U. Schoepflin), відсоток цитування не 
журнальних джерел в академічній періодиці достатньо високий у різних галузях знання і коливається від 6\% до 65\%, використання при підрахунках бібліометричних параметрів лише періодичних видань достатньо коректно відображає цілісну картину генезису наукових публікацій [8].

Сфера застосування наукометричних методів достатньо широка. Так, у багатьох країнах вони використовуються для формування науково-технічної політики, а також для прийняття рішень стосовно фінансування окремих наукових колективів та дослідницьких програм.

У якості інструмента досліджень використовуються наукометричні бази даних, першими серед яких були продукти вищезгаданої корпорації Thomson Reuters. Індекс цитування для статей опублікованих в наукових журналах («Science Citation Index (SCI)») визначається за допомогою он-лайнового продукту корпорації - Web of Science. Для визначення чисельного показника важливості наукового журналу, так званого Імпакт-фактору (IF) використовується БД «Journal Citation Report».

Розрахунок імпакт-фактору базується на трирічному періоді. Наприклад, імпакт-фактор журналу в 2009 році $\mathrm{I}_{2009}$ обчислюється у такий спосіб: $\mathrm{I}_{2009}=\mathrm{A} / \mathrm{B}$, де:

А - число цитувань протягом 2009 року в журналах, що відслідковуються Інститутом наукової інформації, статей, опублікованих у даному журналі в 2007-2008 роках;

В - число статей, опублікованих у даному журналі в 2007-2008 роках.

Варто зазначити, що окрім згаданого імпакт-фактору, в наукометричних дослідженнях широко використовуються і його похідні: aggregate impact factor, 5Year Journal Impact Factor, тощо.

Наступною, не менш значущою, наукометричною базою став продукт відомого видавництва Elsevier - Scopus. Наукометричний аспект БД Scopus важливий, але не основний. В першу чергу - це реферативна база. Саме на цій специфічності і наголошують розробники (http://elsevier.ru/products/product_scopus)

Серед наукометричних показників, які генерує БД Scopus, особливої «популярності» набув h-індекс, який $є$ кількісною характеристикою продуктивності вченого, заснованої на кількості його публікацій і кількості цитувань цих публікацій. Індекс обчислюється на основі розподілу цитувань робіт даного дослідника. Індекс Хирша був розроблений, щоб одержати більше адекватну оцінку наукової продуктивності дослідника, чим можуть дати такі прості характеристики, як загальне число публікацій або загальне число цитувань. Індекс добре працює лише при порівнянні вчених, що працюють в одній області досліджень, оскільки традиції, пов'язані із цитуванням, відрізняються в різних галузях науки (наприклад, у біології й медицині h-індекс набагато вищий, ніж у фізиці).

Паралельно з комерційними наукометричними БД розробляються і функціонують некомерційні продукти, які доступні в мережі Інтернет. Першим серед них варто назвати портал SCImago Journal \& Country Rank [10], розроблений icпанською дослідницькою групою Scimago. Даний портал містить у собі показники рівня наукових журналів і наукових досліджень по країнам і по областям. Показники розроблені на основі інформації, що міститься в БД Scopus . Ця пла- 
тформа бере свою назву від SCImago Journal Rank (SJR) indicator, разработаного SCImago на основі широко відомих алгоритмів Google PageRank тм [12].

Показник SCImago Journal Rank (SJR) - це аналог імпакт-фактору, що генерується Web of Science. Його значимість підтверджує той факт, що він почав використовуватися БД Scopus в якості додаткового показника оцінки журналів. Разом з іншим показником - SNIP - він $є$ вільно доступним в онлайн-режимі на веб-сайті www.journalmetrics.com, а також інтегрированим в базу даних рефератів та цитуваннь Scopus.

В ряду некомерційних наукометричних продуктів варто назвати і такі, як інструментарій Google PageRank тм та аналітичну платформу Eigenfactor.org ${ }^{\mathrm{TM}}$. [9] Хоча ними перелік вільних продуктів не обмежується.

Використання показників, як комерційних, так і некомерційних наукометричних продуктів, завжди не однозначне і має свої позитивні і негативні сторони. В ряду негативних факторів для українських інституцій суттєвим $\epsilon$ той факт, що український сегмент науковців, наукових журналів і збірників, якими оперують БД дуже і дуже обмежений.

Через цілу низку причин існуючі покажчики цитування не завжди повно відображають публікації учених окремих країн. Тому деякі країни проводять роботи із формування національних індексів цитування. Така практика сприймається неоднозначно. Серед критичних зауважень можна почути i такі, які порівнюють іiі з розробкою національної математики чи хімії. Але не зважаючи на це, у 1989 році у Китаї була створена національна база даних (Chinese Science Citation Database), яка нараховує більше 1000 найменувань китайською мовою. Свропейська комісія також прийняла рішення про створення альтернативної бази даних із європейських наукових публікацій, де були б повніше представлені видання німецькою, французькою, італійською та іншими європейськими мовами. Японія і Тайвань здійснюють аналогічні проекти. У Росії у 2005 році при підтримці міністерства освіти і науки Російської Федерації розпочато формування Російського індексу цитування.

В Україні практика наукометричних досліджень на національному рівні пов'язана $з$ ініціативою Академією наук України та безпосередньо Національною бібліотекою України імені В. І. Вернадського (НБУВ) і датується 2009 роком. Роботи велися у трьох напрямках.

Перший напрямок наукометричних досліджень був організований на базі загальнодержавного депозитарію «Наукова періодика України», офіційне формування якого розпочате в тому ж 2009 році. Поштовхом до цього став Наказ Вищої атестаційної комісії України та Національної академії наук України від 07.07.2008 N 436/311 (Зареєстровано в Міністерстві юстиції України 15 січня 2009 р. за N 20/16036) «Про затвердження Порядку передавання електронних копій періодичних друкованих наукових видань на зберігання до Національної бібліотеки України імені В. І. Вернадського». Станом на квітень 2010 року депозитарій налічує 1245 назв електронних копій періодичних друкованих наукових фахових видань з глибиною ретроспективи в три роки. В ході робіт було створено інформаційну технологію формування та мережевого використання 
документальних ресурсів депозитарію. Важливим започаткуванням стали також наукометричні дослідження, зокрема, рейтингування періодичних видань за ступенем їх інтегрованості в систему соціальних комунікацій.

Короткий звіт Національної бібліотеки України імені В. І. Вернадськогопро наукову та науково-організаційну діяльність у 2009 році (http://www.nbuv.gov.ua/library/zv_2009.html)

Другий напрямок наукометричних досліджень НБУВ - комплекс наукометричних досліджень щодо стану представлення української науки у базі даних Scopus, публікаційної активності та показників цитованості вітчизняних суб'єктів системи наукових комунікацій. Зокрема, виявлено, що за публікаційною активністю серед держав світу Україна займає 34-е місце, серед держав Європи 19-е, серед держав СНД - друге. Результати дослідження оперативно представлялися на веб-сторінках: «Рейтинг установ НАН України» (50 установ), «Рейтинг установ АМН України» (9 установ), «Рейтинг установ УААН» (2 установи), «Рейтинг ВН3 України» (87 ВН3) та «Рейтинг науковців України» (наведено наукометричні показники 100 найбільш цитованих у Scopus науковців - працівників українських інституцій; при аналізі не враховувалося самоцитування авторів). Упорядкування показників в усіх рейтингах проведено за $\mathrm{h}-$ індексом, а в його межах за кількістю цитувань.

В рамках третього напрямку досліджень було проведено бібліометричний аналіз інформаційних ресурсів реферативної бази даних «Україніка наукова» у видовому та тематичному аспектах.

Початок систематичних наукометричних досліджень на рівні НБУВ, як науково-дослідницького бібліотечного центру країни, могли стати серйозним підгрунтям для подальшого теоретичного і практичного розвитку цього напрямку в менеджменті науки та бібліотек. Але $\epsilon$ всі підстави для побоювань щодо припинення робіт, які так і не встигли вийти на відповідний рівень.

Ще одним споживачем даних наукометричних досліджень являється Міністерство освіти і науки України i, зокрема, кожний вищий навчальний заклад країни. Для нашого відомства 2009 рік теж став роком ініціювання з використання наукометричних даних. В даному випадку стимулом слугувала Постанова КМ України від 17 лютого 2010 року № 163 «Про затвердження Положення про дослідницький університет» (попередньо його слухання відбулися ще 23 вересня 2009 року). В Положенні висунуто ряд жорстких вимог, що визначають рівень відповідності ВНЗ цьому Положенню. Так, згідно до цих вимог, університету-претенденту необхідно мати потужний кадровий потенціал (не менше ніж 150 докторів наук, професорів і 500 кандидатів наук, доцентів); свою видавничу базу, щорічно публікувати не менше 25 навчальних посібників 3 грифом $\mathrm{MOH}$, не менше 30 статей у фахових виданнях, що входять до Міжнародних наукометричних баз даних (на 100 науково-педагогічних працівників та науковців). Відповідно, на сайті Міністерства освіти і науки України подані Рекомендації пошуку журналів з імпакт-фактором та інших журналів, які входять до міжнародних наукометричних баз даних.

Що насторожує в Положенні, так це занадто однобокий погляд на використання наукометричних бази даних, які мають унікальні функціональні можли- 
вості, що не обмежуються визначенням лише одного імпакт-фактору.

Звертає увагу на себе ще й рівень готовності українських ВНЗ до роботи 3 наукометричними базами. Окрім проблем матеріальних тут слід назвати і такі, як відсутність знань, вмінь і навичок роботи з подібними продуктами у представників наукових частин та бібліотек ВНЗ. Мабуть і з цієї причини також, залишився практично не поміченим тріал-період доступу до БД Scopus, який надавався через Асоціацію та мережу УРАН у 2009 році. Сьогодні жоден ВНЗ України не передплачує хоча б одну науковометричну базу даних.

Але не зважаючи на це, керівництво ВНЗ активно зацікавилося в отриманні тих, чи інших наукометричних результатів, як правило це - або імпакт-фактори вузівських журналів, або h-індекс для науковців. В ситуації, що склалася, логічно згадали про бібліотеки, які традиційно підписують та використовують БД. Бібліотеки, відповідно, постали пред складною задачею. По-перше, доступ до комерційних наукометричних БД на сьогодні відсутній. Організація тріалперіоду, який міг би стати тимчасовим і недовготривалим виходом, проблематична, бо в 2009 році він надавався Україні. По-друге, бібліотеки не мають практичного досвіду роботи з подібними базами і не володіють, мягко кажучи, темою. Проте, це ніякою мірою не означає, що бібліотека може випасти з процесу наукометричних досліджень у ВНЗ.

На даному етапі $є$ сенс проаналізувати проблему і виробити відповідну модель поведінки, яка полягає в наступному. Бібліотека повинна забезпечити доступ до БД, володіти методологією пошуку, надавати консультаційну допомогу користувачеві, вести інформаційний блок на сайті бібліотек, де будуть зібрані матеріали відповідної тематики. Ось така, на нашу думку, в загальних рисах і $\epsilon$ модель поведінки бібліотеки ВНЗ у відношенні до наукометричних БД. Щоб така модель стала життєздатною необхідно також провести відповідну роботу 3 навчання персоналу бібліотеки.

Крім того сама бібліотека є замовником на проведення наукометричних та бібліометричних досліджень з метою корегування задач 3 комплектвання інформаційних ресурсів. В результаті аналізу бібліометричних показників, отриманих з відповідних БД, може бути визначена динаміка бібліотечного фонду 3 різних тематичних напрямків; встановлене оптимальне відношення видового складу інформаційних ресурсів за темою; виявлені найбільш розроблені тематичні напрямки наукових досліджень, кожне $з$ яких найбільш або найменш забезпечене фундаментальними працями; визначене ядро профільних журналів, які в подальшому комплектуються тощо.

Розглянемо використання наукометричних БД на прикладі науковотехнічної бібліотеки НТУУ «КПІ». Особливості досліджень були наступні. Була використана лише одна БД - БД Scopus. Об'єктами вивчення були автори доктори наук НТУУ «КПІ», накові журнали НТУУ «КПІ» та сам НТУУ «КПІ» (розробка наукової карти). Для авторів та журналів визначалися такі показники: кількість публікацій у Scopus; кількість цитувань у Scopus; h-індекс. Кілька зауважень щодо розробки наукової карти Університету. Ця робота була започаткована в навчально-експерементальному режимі 3 власної ініціативи спів- 
робітників бібліотеки. Але з причини обмеженості доступу інформація до карти була підготовлена частково. Як видно з вище викладеного, дослідження проводилися фрагментарно. Але в цілому поставлені задачі були виконані, зроблені певні методологічні висновки. Основний 3 них - для коректного відбору публікацій українських авторів, журналів та установ потрібна ретельна попередня підготовка пошукової стратегії.

Використання БД у наукометричних дослідженнях поряд з явними перевагами має й певні обмеження. Одне з них пов'язане з відсутністю стандарту стосовно бібліографічних даних, які заводяться до бази. Це в свою чергу впливає на коректність результату пошуку в базі, як з точки зору представлення інформації, так і з точки зору релевантності результатів пошуку. Причинами помилок в бібліографічних даних можуть бути різні чинники. Помилки допущені при реферуванні літератури, особливо, якщо ця література неангломовна, а на приклад, українською або російською мовами. Ряд помилок зроблених видавцями журналів або розробниками БД. I нарешті, помилки допущені самими авторами. Ці помилки позначаються вже на першому етапі наукометрического дослідження, негативно впливаючи на повноту відбору релевантних даних для наступного аналізу. Істотні помилки, що впливають на коректність остаточних висновків, можуть також бути зроблені на наступному етапі - при інтерпретації отриманих даних, особливо якщо відсутній необхідний досвід, а також можливість перевірки інформації, яка викликає сумнів.

Дані про авторів. У БД імена авторів вказуються так, як вони наведені в першоджерелі - без якої-небудь стандартизації. У одних випадках імена скорочуються до ініціалів, в інших - перше ім'я подане повністю, решта скорочені. При цьому скорочена форма «Прізвище, ініціали» може бути ідентичної для декількох різних авторів. Крім того, автори можуть використовувати різні форми написання власного ім'я в різних публікаціях. Для українського автора власне ім'я в англомовній літературі може транслітеруватися як з української, так і 3 російської мови. Правила і стандарти транслітерації не завжди використовуються коректно. Тому доречним буде індивідуальне авторське редагування відображення в базі імені шляхом зворотного зв'язку із розробниками БД.

Назви журналів - також велике джерело бібліографічних труднощів, зокрема, у зв'язку з відсутністю стандартизації їхніх назв у рамках навіть однієї й тим більше різних БД. Користуючись БД для пошуку та ідентифікації назв журналів потрібно мати на увазі те, що часом журнали можуть змінювати назви. Крім того, у БД можуть бути представлені як повні, так і скорочені назви журналів. Одне видання може розділитися на два й більше, і це також необхідно враховувати в наукометричних дослідженнях. Відбувається й зворотній процес - злиття декількох журналів в один. Поряд із цим, у журналу може змінитися видавець або країна видання. Два журнали можуть мати однакові або дуже схожі назви.

Назви організацій. Серйозні бібліографічні труднощі породжують і назви установ, зокрема, в зв'язку з їхнім перекладом на іншу мову, а також через неоднозначність при використанні скорочених назв (абревіатур). Тому дуже важливі додаткові відомості про організацію для іiі ідентифікації: географічне по- 
ложення (адреса) i/або відомча приналежність. Як і журнали, організації можуть змінювати свою назву, об'єднуватися або розділятися. Крім того, досить часто назви організацій, де виконувалася робота, у БД просто відсутні. Таким чином, при пошуку публікацій організації варто розглянути всі можливі варіації іiі назви й адреси (останні також можуть мінятися з часом), включаючи лінгвістичні варіації, так само як у випадку окремих авторів. Непередбачені способи написання, неповні, а також відсутні адреси можуть, звичайно, вплинути на повноту встановленого списку публікацій.

Крім формальних проблем, пов'язаних з некоректністю відомостей в бібліографічному записі БД, ще раз варто наголосити на недостатньому рівні представлення українського наукового сегменту в БД. Тому отримати повні наукометричні показники для українських організацій, журналів або авторів не представляється можливим на сьогодні.

Обмеженість у доступу до повного ресурсу, зокрема до інструментарію комерційних БД, спонукає до вивчення і освоєння вільних наукометричних ресурсів. Тому зараз перед співробітниками бібліотеки стоїть завдання вивчення таких продуктів, як EigenFactor (Ranking and Mapping Scientific knowledge), SJR SCImago Journal and Country Ranking, PageRank, Google Scholar, тощо.

Нова і така, що швидко розвивається сфера, застосування бібліометричних методів - прогнозування науково-технологічного розвитку. Зокрема, подібні дослідження ведуться в рамках національних програм Форсайта (від англійського foresight - передбачення або погляд у майбутнє). Наприклад, в останньому (восьмому) японському науково-технологічному Форсайті, результати якого були опубліковані в 2005 р., на основі бібліометричних методів були виділені 133 напрямки, досліджень, що швидко розвиваються. Для кожного 3 них був проведений детальний аналіз, що охоплює тенденції розвитку, співцитування, контент-аналіз, виявлення провідних наукових шкіл, тренди взаємозв'язків між окремими напрямками, формування нових напрямків досліджень на стику наукових дисциплін тощо. Результати аналізу використовувалися при підготовці експертних опитувань і розробці прогнозу науково-технологічного розвитку Японії до 2030 р. Наукометричні дослідження проводилися також при формуванні переліку ключових технологій у Франції, підготовці прогнозів у Кореї, Німеччині й ряді інших країн.

Теоретичні засади бібліометричного аналізу визначені загальною тенденцією розвитку сучасного пізнання, що характеризується, насамперед, різким збільшенням значення теоретичних досліджень, поглибленням процесів формалізації, математизації наукового знання. Використання методів кількісного аналізу, зокрема бібліометрії, $є$ наслідком загальнонаукових процесів. Дослідження еволюції бібліометрії як пізнавального методу аналізу науки, надає можливість констатувати існування об'єктивної тенденції переходу від простих бібліометричних показників, що характеризують зовнішню сторону функціонування науки (кількість публікацій, рівень цитованості) до таких їх аналогів, що відображають якісні (змістовні) аспекти наукової діяльності (кластерні методики).

Дослідження когнітивних можливостей бібліометричного аналізу в період 
освоєння нових інформаційних технологій і переходу бібліотечної системи України на якісно новий техніко-технологічний рівень виявило, що потенціал бібліометричних методів у вітчизняних бібліотекознавчих дослідженнях ще не використано повною мірою. Зважаючи на умови та рівень розвитку сучасного бібліотекознавства в Україні, найперспективнішим засобом оптимізації досліджень у бібліотечній сфері є створення на базі кластерних методик проблемних інтелектуальних бібліометричних систем, які надають можливість одержувати структурні (якісні) картини стану науки, що відображають передній край досліджень і виявляють когнітивну структуру бібліотечної науки, їі концептуальний каркас.

\section{СПИСОК ДЖЕРЕЛ}

1. Вернадский В. И. Трудь по всеобщей истории науки. - М. : Наука, 1988. - c. 223-224.

2. Кобєлєв Олексій Миколайович. Бібліометричний аналіз розвитку українського бібліотекознавства в 1970- 1990-ті рр.: Дис. канд. пед. наук: 07.00.08 / Харківська держ. академія культури. - Х., 2001. - 245 арк. Бібліогр.: арк. 179-217.

3. Кобєлєв О.М. Бібліометрія в системі бібліотекознавчого знання / О. М. Кобєлєв // Вісн. Харк. держ. акад. культури.-Х., 2001. Вип.6. c. 157-167.

4. Кобєлєв О. М. Порівняльні бібліометричні дослідження у бібліотекознавстві. Ч.1 : Теоретичний аспект / О. М. Кобєлєв // Вісн. Кн. палати. - 2000. - №1.- c. 24-26.

5. Мохначева Ю. В. Инструмент для исследования / Ю. В. Мохначева, Н. А. Слащева, Т. Н. Харыбина // Библиотека. - 2004. - № 10. - с. 19-21.

6. Мохначева Ю. В. Методика определения значимости научных публикаций / Ю. В. Мохначева, Т. Н. Харыбина. // Библиосфера. - 2008. - № 3. - c. $23-33$.

7. Онопрієнко В. Міжнародний рейтинг української науки / В.Онопрієнко // Вісник НАН Украӥни. - 2005. - №5. - с. 20-31.

8. Писляков В. В. Методы оценки научного знания по показателям циитирования // Соччиологический журнал. - 2007. №1. - c. 128-140.

9. [Платформа] Eigenfactor.org ${ }^{T M}$. - Режим доступу http://eigenfactor.org/. - Назва з екрану.

10.[Портал] SCImago Journal \& Country Rank. - Peжuм docmyny: http://www.scimagojr.com/. - Назва з екрану.

11. Слащева Н. А. Электронная информаџия в наукометрических исследованиях / Н. А. Слащева, Ю. В. Мохначева // Науч.-техн. информ. Сер. 1, Документ. источники информ. - 2003. - № 5. - с. 21-26.

12. Функиіі панелі інструментів: Основи PageRank. - Режим доступу: http://www.google.com/support/toolbar/bin/answer.py?hl=uk\&answer $=79$ 837. - Назва з екрану. 


\section{2. ІНСТИТУЦІЙНІ РЕПОЗИТАРІЇ ЯК ПОШТОВХ ДО НОВИХ БІБЛІОМЕТРИЧНИХ ДОСЛІДЖЕНЬ В УКРАЇНІ}

Автор не підтримує політику відкритого доступу.

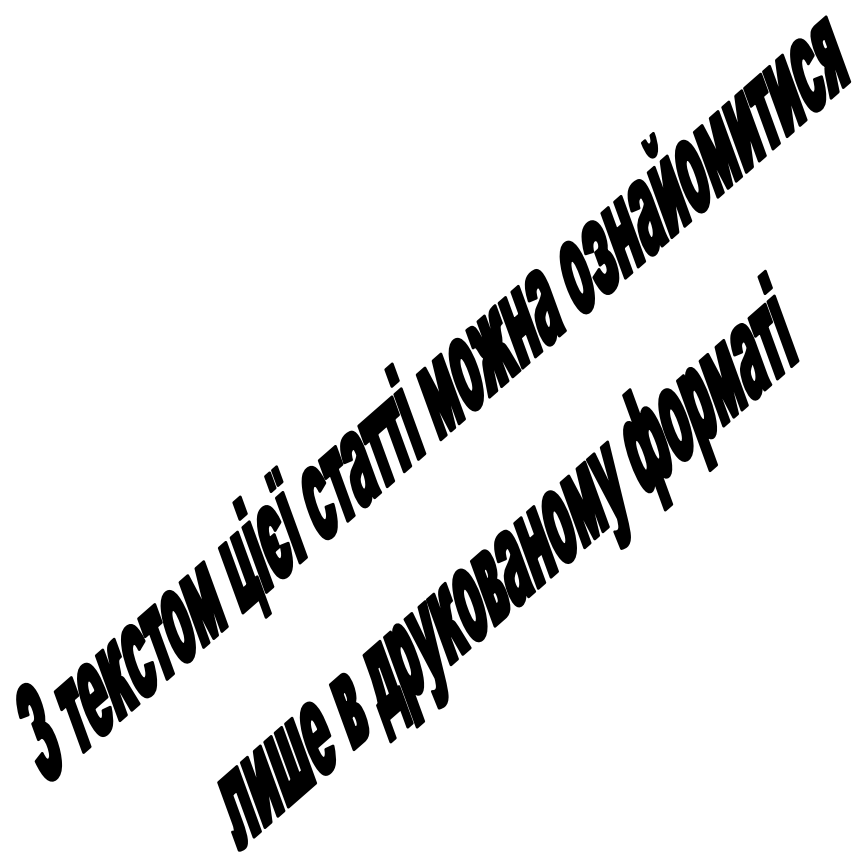




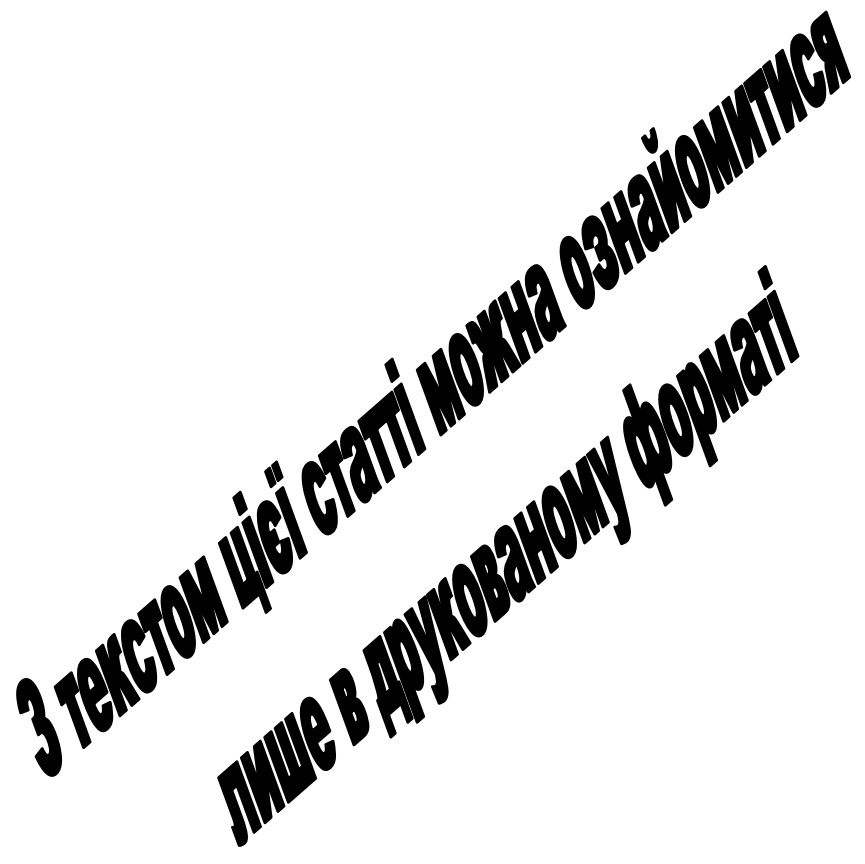




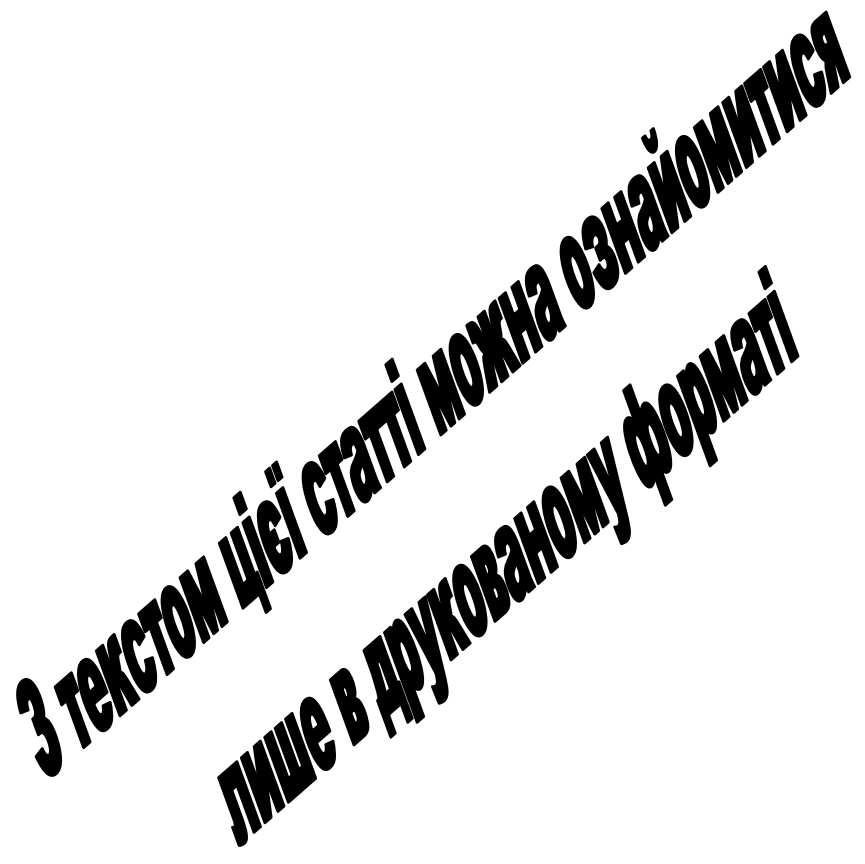




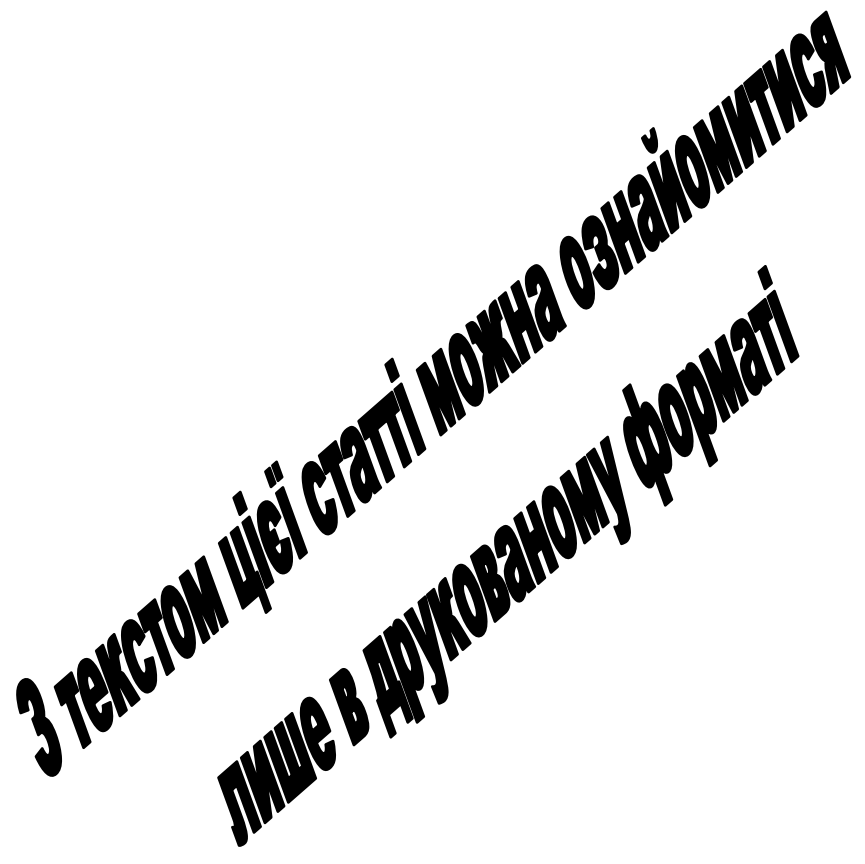




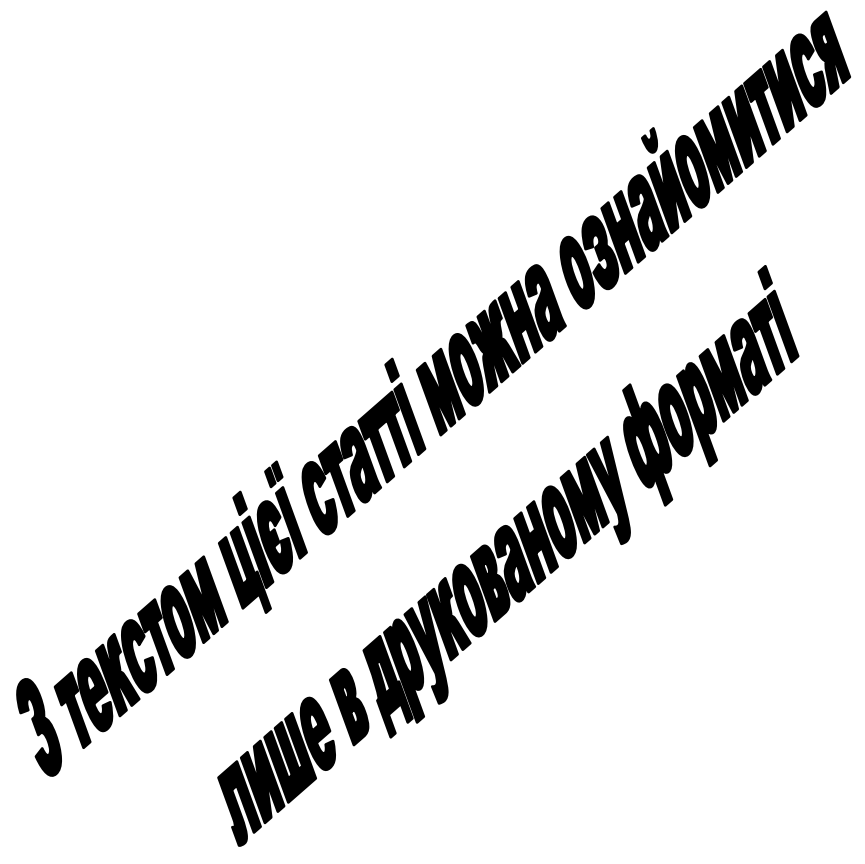




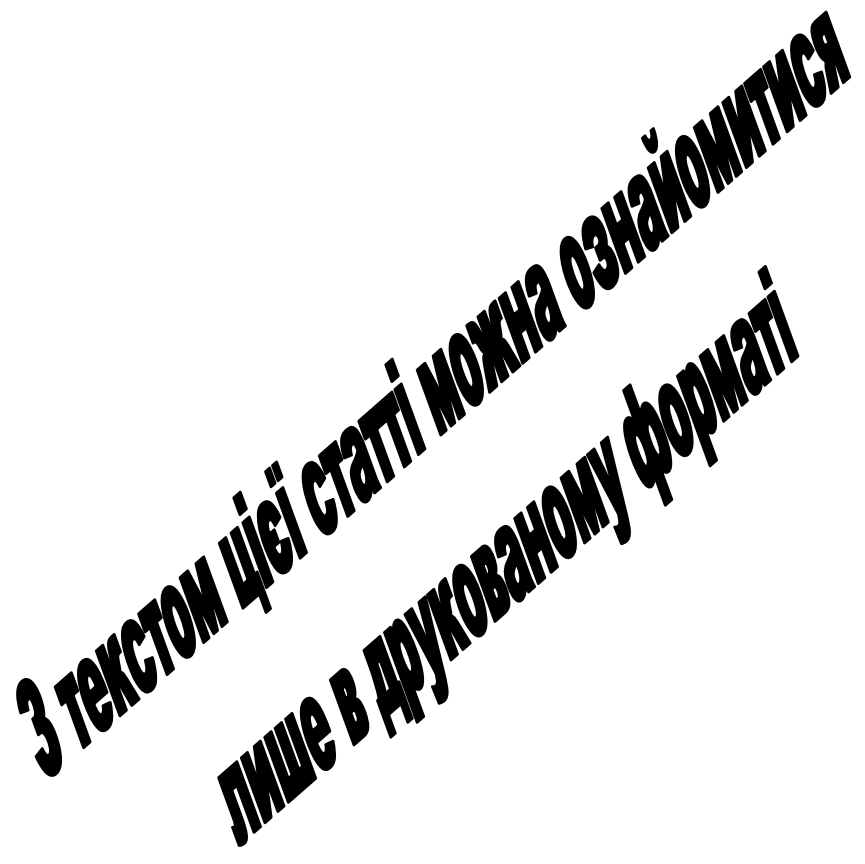




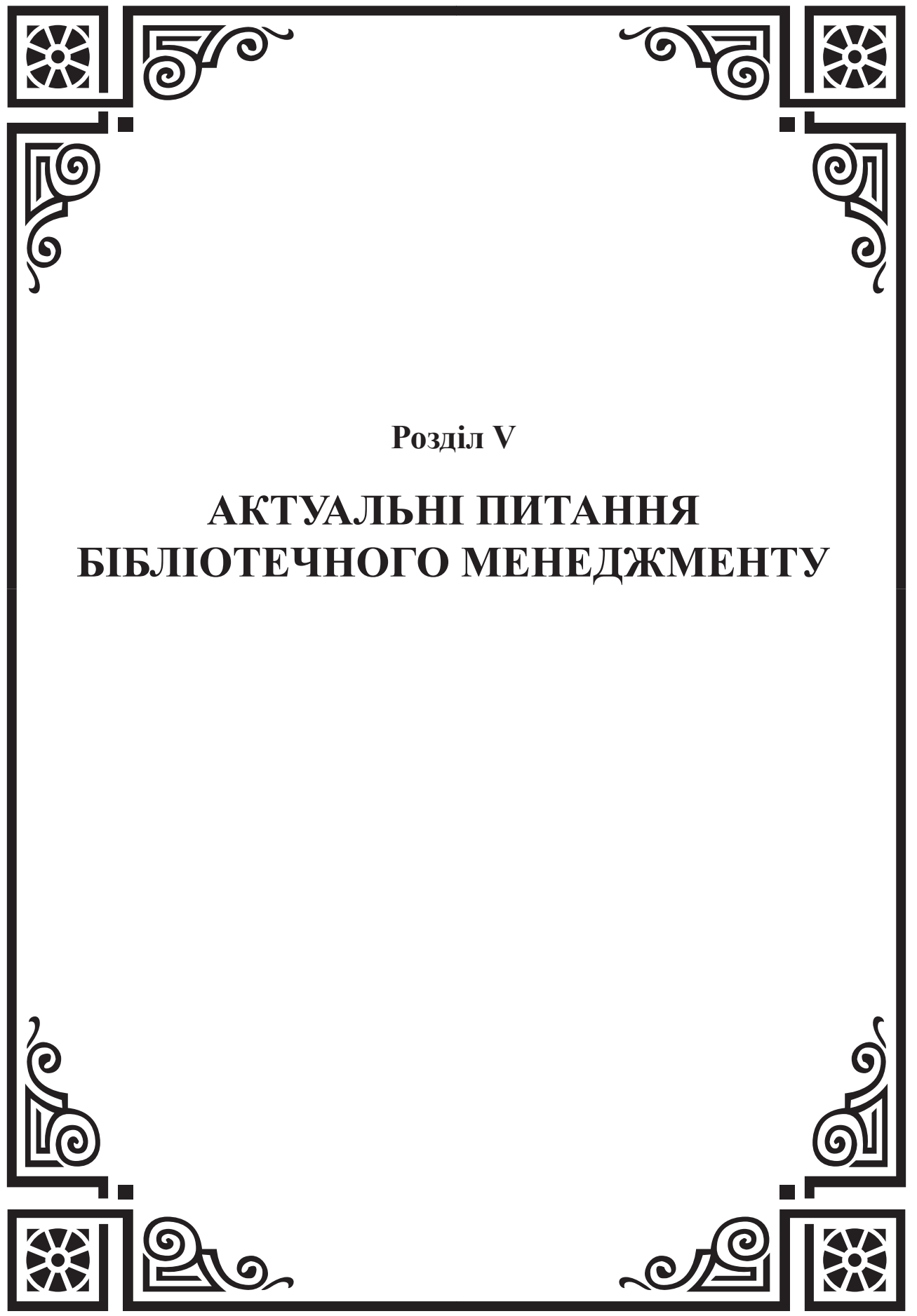




\section{1. СИСТЕМА МЕНЕДЖМЕНТУ ЯКОСТІ НАУКОВОЇ БІБЛІОТЕКИ ВНЗ В УМОВАХ ПЕРЕБУДОВИ СИСТЕМИ ВИЩОЇ ОСВІТИ}

Конкурентоспроможність бібліотек вищих навчальних закладів на ринку освітніх послуг залежить від якості пропонованих користувачам послуг. Для забезпечення потреб користувачів якісними, стабільними послугами, діяльність бібліотеки повинна будуватися на засадах системи менеджменту якості (СМЯ), як одному з інноваційних видів бібліотечної діяльності, основним принципом якого $€$ забезпечення існуючих $\mathrm{i}$ можливих інформаційних потреб користувачів бібліотеки.

Менеджмент якості бібліотеки - це система методів, засобів та видів діяльності, спрямованих на виконання вимог та очікувань користувачів бібліотеки по відношенню до якості роботи самої бібліотеки та створених нею інформаційних продуктів та послуг. Розроблена та впроваджена в практику єдина політика, методологія та методика системи менеджменту якості націлені на задоволення інформаційних потреб користувачів ресурсним потенціалом бібліотеки при участі всіх бібліотечних працівників.

Дослідженню теоретичних та окремих практичних питань організації та впровадження системи менеджменту якості в бібліотечну діяльність присвячені роботи авторів далекого та близького зарубіжжя: Розвіти Полл, Бокхорст П., Дрешер Ю. Н., , Атланової Т. А., Дубровіної Л. А., Кочетова А. І., Ахмадової Ю. А., Галімової Е. А., Клюєвої В. К., Лопатіної В. А.

Заслуговують уваги досвід і практичні результати роботи з упровадження та сертифікації системи менеджменту якості в бібліотеках Росії: Науковотехнічній бібліотеці Томського політехнічного університету, Науковій бібліотеці Новосибірського державного технічного університету, Науковій бібліотеці Ставропольського державного аграрного університету, зональній науковій бібліотеці Вороніжського державного університету, Тамбовській обласній універсальній науковій бібліотеці ім. А. С. Пушкіна, в Ярославському обласному методичному об'єднанні бібліотек освітянських закладів. 32004 року започатковано цю роботу в Псковській обласній універсальній науковій бібліотеці та бібліотеках області (організовані зональні Школи якості за підтримки Міністерства культури та масових комунікацій РФ).

На 8-й Міжнародній науково-практичній конференції «Менеджмент вузовских библиотек: вузовская библиотека в системе обеспечения качества образования» (Мінськ, Білорусія, 2007 р), організаторами якої виступили Білоруська бібліотечна асоціація, Академія управління при Президенті Республіки Білорусь та Фундаментальна бібліотека Білоруського державного університету, значну увагу було приділено найважливішим аспектам забезпечення якості діяльності бібліотек ВНЗ.

На Україні питанням впровадження СМЯ в бібліотечну діяльність приділяється менш уваги, але вони визнані актуальними, про що свідчать статті Виноградової Е., Рябченко И., Бочарова В., Вороніної О. О., Грищенко Т., Нікітен- 
ко О. М., Влащенко Л. Г., Шевченко В. М., Шкурко О. П., Саприкіної Г., Ткаченко Т. П., Дригайло В. Г., Новальської Т.

У вересні 2008 р. Національний авіаційний університет (м. Київ), перший серед державних ВНЗ України, одержав сертифікат відповідності СМЯ університету вимогам міжнародного стандарту якості ISO 9001:2000, бібліотека, як структурний підрозділ університету, брала активну участь в розробці, впровадженні та удосконаленні СМЯ. Працюють в напрямку розробки і впровадження системи менеджменту якості в бібліотечну діяльність бібліотека Харківського національного університету радіоелектроніки та наукова бібліотека Донецького національного університету економіки i торгівлі імені Михайла ТуганБарановського.

Аналіз розглянутого матеріалу свідчить, що в умовах інтенсивного розвитку сучасних комп'ютерно-телекомунікаційних технологій, їх інтеграції в бібліотечно-інформаційну діяльність, змінюються процеси та структура бібліотек ВН3, послуги та засоби їх надання, критерії оцінки ефективності їх діяльності. Впровадження системи менеджменту якості, стандартизація бібліотечних процесів дасть змогу бібліотекам позиціонувати себе як бібліотечноінформаційні центри ВНЗ, користуватися єдиними одиницями виміру бібліотечної роботи для оцінки стану і прогнозу розвитку, керуватися єдиними нормами, правилами, технологіями, формами створення інформаційних ресурсів. При впроваджені системи менеджменту якості у роботу бібліотеки змінюється документаційна культура сучасної бібліотеки, удосконалюються діючі документи та розробляються нові, які кожна бібліотека визначає для себе як актуальні.

Але в бібліотечній практиці відсутня, розроблена на державному рівні, політика впровадження і сертифікації СМЯ. Державою не фінансуються й інноваційні технології, які впроваджуються в бібліотеках, відсутні теоретично обгрунтовані практичні рекомендації з удосконалення бібліотечної діяльності в умовах впровадження системи менеджменту якості, нормативно-методична база СМЯ діяльності бібліотек, бібліотечні працівники не мають практичної підготовки з питань впровадження системи якості в бібліотечні процеси.

Таким чином, виникає необхідність теоретичного обгрунтуваня та розробки практичних рекомендацій щодо впровадження основних принципів системи менеджменту якості в діяльність бібліотек, головний 3 яких - задоволення інформаційних запитів користувачів бібліотеки.

На рівні бібліотеки запровадження системи менеджменту якості є частиною процесу іiі реструктуризації з використанням реінжинірингу і системи безперервних поліпшень технологічних процесів і послуг.

Якість роботи бібліотеки залежить від визначення місії, яку вона виконує виходячи із завдань і цілей навчального закладу. Визначаючи свою місію бібліотеки ВНЗ керуються Законами України «Про освіту», «Про вищу освіту», «Про бібліотеки і бібліотечну справу», «Про національну програму інформатизації», «Примірним положенням про бібліотеку вищого навчального закладу 34 рівнів акредитації». 
Місія бібліотеки університету - це забезпечення літературою та інформацією навчально - виховного та наукового процесів вищого навчального закладу, сприяння реалізації державної політики у галузі освіти і культури, дотримання принципів гуманізму, демократії, пріоритет загальнолюдським цінностям і моралі. Місія ураховує потреби користувачів бібліотеки, виходячи з цього, місію вузівської бібліотеки можна сформулювати таким чином: формування, належне зберігання, використання і створення системи доступу до інформації для всіх категорій користувачів, надання їм рівних можливостей у задоволенні інформаційних потреб. Виходячи з формування своєї місії, бібліотека формує довгострокові цілі і короткострокові завдання. Місія, цілі і завдання відповідають інтересам користувачів бібліотеки, ії співробітників, суспільства в цілому. Свою місію бібліотека виконує створюючи своїм користувачам умови для задоволення їх потреб в інформаційному забезпечені, надані широкого спектру послуг на самому високому рівні, впроваджуючи в свою роботу інноваційні технології, нові форми і методи роботи. Місія дозволяє продемонструвати призначення бібліотеки, іiї прагнення, і засоби, які вона використовує для досягнення своїх цілей.

Політика бібліотеки в області якості спрямована на забезпечення високої якості бібліотечно-інформаційних послуг, які надаються користувачам бібліотеки. Політика бібліотеки ВНЗ у галузі якості формується на засадах Політики якості університету і спрямована на сприяння у досягненні високої якості підготовки фахівців шляхом постійного вивчення складу користувачів, їх вимог, потреб, очікувань; підвищення якості бібліотечно-інформаційних послуг; забезпечення широкого та оперативного доступу всіх категорій користувачів до інформаційних ресурсів; напрацювання нових та удосконалення традиційних технік бібліотечно-інформаційної роботи; впровадження новітніх інформаційних технологій та безперервного поліпшення якості на засадах ефективного зворотнього зв'язку з користувачами.

Основні принципи політики бібліотеки у галузі якості:

- орієнтація на користувача;

- сприяння конкурентній перевазі університету на ринку освітніх послуг;

- досягнення лідерства в оволодінні передовими бібліотечними технологіями;

-впровадження прозорого та обгрунтованого менеджменту;

-безперервний моніторинг якості;

- постійне поліпшення;

-постійне підвищення кваліфікації бібліотечних працівників.

Цілі бібліотеки ВНЗ в забезпеченні якості можна сформувати так:

-визначення основної групи користувачів;

-виявлення їх існуючих та можливих потреб;

- створення адекватних потребам послуг;

- надання послуг на максимально високому рівні;

-підвищення професіоналізму персоналу;

-підвищення ефективності взаємодії з усіма структурними підрозділами університету; 
-вимірювання ефективності роботи та зіставлення результатів 3 поставленими цілями;

- створення умов для постійного підвищення ефективності роботи.

Запорукою реалізації цілей НБ ДонНУЕТ в галузі якості є постійне розширення переліку послуг на базі освоєння передових технологій і інформаційних сервісів, модернізація і розширення матеріально-технічної бази бібліотеки на основі впровадження інформаційно- телекомунікаційних технологій, підвищення персональної відповідальності керівників структурних підрозділів, постійний самоконтроль та самоаналіз.

Система менеджменту якості бібліотеки складається з наступних елементів: користувач, персонал бібліотеки, ресурси, бібліотечні процеси і технології.

Важлива роль у якісному забезпечені навчально-наукового процесу університету належить інформаційним ресурсам бібліотеки.

Від якості інформаційного забезпечення навчально-наукового процесу університету залежить якість освіти, так як дуже важливо на якій освітній платформі відбувається формування політичної, економічної, правової, наукової, культурної свідомості майбутніх фахівців. Формуючи документально інформаційне середовище, бібліотека бере на себе відповідальність за забезпечення інформаційних потреб навчального процесу новими знаннями, новою інформацією.

Для повноцінного забезпечення навчально-наукової діяльності університету фонд бібліотеки повинен складатися із достатньої кількості періодичних видань, книжкової продукції, електронних документів.

Періодичні видання в бібліотеках ВНЗ відіграють значну роль в забезпеченні навчального та наукового процесів університету. Публікації у наукових періодичних виданнях дозволяють ученим брати участь у наукових дискусіях, заявляти пріоритет на наукове відкриття, мати доступ до необхідної наукової інформації. Тут є всі новини щодо вітчизняних та зарубіжних досліджень, наукових відкриттів, з практичної діяльності. На публікації в періодичних виданнях можна посилатися та цитувати в наукових працях, використовувати для здобуття нових знань, в професійній діяльності. Періодичні видання здатні задовольнити інформаційні, наукові, загально - освітні та інші потреби користувачів бібліотек ВНЗ. Репертуар періодичних видань бібліотеки повинен відповідати науковим, навчальним та культурно-просвітницьким вимогам університету, постійно оновлюватися і доповнюватися новими періодичними виданнями. Моніторинг змістовної складової документального потоку періодичних видань дозволяє бібліотеці задовольнити попит користувачів на ці види документів.

Особлива увага, при формуванні інформаційних ресурсів бібліотеки, приділяється електронним інформаційним ресурсам, як наявним в бібліотеці, так і забезпеченню доступу до них. Електронні документи, як вид електронної інформації, мають переваги над друкованими: оперативність надходження до користувача, різноманітність доступу, можливість перекачування інформації, можливість одночасного використання одного документу кількома користувачами, 
виключення можливості придбання великої кількості примірників однієї назви видання, менша вартість документу.

Пріоритетним напрямком в роботі наукових бібліотек вищих навчальних закладів може бути створення повнотекстових електронних колекцій документів науковців ВНЗ і подальше об'єднання цих БД в єдині корпоративні мережі 3 віддаленим доступом користувачів бібліотек-участниць створення цих ресурсів. Внутрівузівські видання - це унікальна інформація, яка постійно використовується в навчальному процесі, в наукових дослідженнях вчених університету, аспірантів, студентів. Ці документи видаються невеликими тиражами, доступ до них має обмежений круг користувачів, а інформаційне та наукове значення цих ресурсів дуже велике. Отже, е-версії цих документів мають велику наукову цінність для наукової спільноти України. Наприклад, в науковій бібліотеці ДонНУЕТ «Повнотекстова колекція видань ДонНУЕТ» $є$ складовою в створені електронної бібліотеки університету. Роботу над проектом розпочато в липні 2003 року. До бібліотеки надходять електронні версії підручників, навчальнометодичних і методичних посібників, монографій, авторефератів дисертацій, матеріалів наукових конференцій створених викладачами університету. Колекція налічує понад 10 тис. повнотекстових документів. Користувачі бібліотеки, працюючи 3 е-каталогом мають можливість переглянути інформацію про сам документ, отримати повний текст документу, при необхідності перенести його на е-носій.

Колекція «Лекції викладачів ДонНУЕТ» почала створюватись 3 березня 2006 року і налічує понад тисячі документів. Лекціями в електронному вигляді забезпечені всі дисципліни які вивчаються в університеті, вони користуються підвищеним попитом серед користувачів бібліотеки. В бібліотеці почався новий етап - оновлення існуючих лекцій та підготовка лекцій по новим дисциплінам. Створення об'єднаного інформаційного ресурсу в межах України створило б комфортні умови для самостійної роботи студентів при вивчені окремих дисциплін, дало б змогу користуватися лекціями викладачів з різних ВНЗ, чим розширило можливості отримання нових знань.

Особливе місце серед повнотекстових електронних документів займають електронні дисертації. Дисертації користуються великим попитом серед користувачів бібліотеки, так як містять всебічний аналіз досліджуваних проблем зумовлених їх актуальністю і новизною запропонованих рішень. В рамках проекту «ЕБ дисертацій ДонНУЕТ» в бібліотеці створюється повнотекстова колекція дисертацій. На першому етапі накопичується первинний масив ЕД. На другому етапі передбачається оцифровка існуючого масиву дисертацій.

Питому вагу бібліотечного фонду повинні складати довідкові видання останніх років, без яких неможливо якісне обслуговування інформаційних запитів користувачів бібліотеки.

В останні роки бібліотеки ВНЗ дуже активно поповнюють свої фонди навчальними виданнями а частка наукових видань поступово зменшується, що негативно впливає на забезпечення наукової складової університетів. Постійний моніторинг співвідношення наукової та навчальної літератури, придбання 
наукових видань по профілю університету, книгообмін науковими виданнями між вищими навчальними закладами, дозволять бібліотеці повною мірою забезпечувати науковців університету необхідними документами.

Орієнтація на інтереси користувача є одним з основних принципів системи менеджменту якості і означає, що значна роль у бібліотеці повинна приділятися отриманню достовірної інформації про їх реальні потреби. Одержання розширеної інформації про потреби та запити користувачів та ступень їх задоволення діяльністю бібліотеки стають провідним напрямком досліджень у підрозділах бібліотеки при впровадженні менеджменту якості в роботу бібліотеки. Вивчення основних категорій користувачів підрозділів бібліотеки, їх інтересів, потреб, мотивацій їх запитів значною мірою обумовлює організацію обслуговування, комплектування фондів, бібліотечний менеджмент. Результати вивчення користувачів бібліотеки певним чином впливають на прийняття управлінських рішень щодо підвищення якості діяльності бібліотеки в цілому.

Перші дослідження інформаційних потреб користувачів проведено у 1950-х роках, переважно у США. В основному це - статистичне, або бібліометричне виявлення найбільш запитуваних джерел інформації. Цей підхід носив односторонній характер. Він не давав об'єктивного уявлення про всю систему пошуку і використання інформації. На той час вивчення інформаційних потреб носило епізодичний, поверхневий, випадковий характер, відсутнім було головне якісний аналіз отриманих даних.

У 1960-і роки серед використаних методик певний інтерес представляє методика вивчення інформаційних потреб користувачів шляхом дослідження їх індивідуальної поведінки методами спостереження і анкетування. Особлива увага приділяється типологічній диференціації користувачів (їх систематизації за освітою, виконуваними функціями, займаною посадою і т.п.). На наш погляд, такий підхід - важливий крок у вивченні інформаційних потреб.

У зв’язку з інтеграцією нових інформаційних технологій в інформаційнобібліотечне забезпечення ВНЗ, прийшло нове розуміння ефективності обслуговування. Проблема ефективності і якості послуг пов'язана не тільки з бібліотечною статистикою, але головним чином, 3 оцінкою їі діяльності користувачем, його задоволеністю бібліотечними послугами. Отримати або виміряти таку інформацію досить складно. Адже економічний аналіз не дає оцінки ступеня задоволеності споживачів, іiі корисно доповнювати соціологічними дослідженнями, що дають детальнішу картину.

При перенесенні акценту з аналізу кількісних показників діяльності бібліотек на якісні виникає можливість використання більш широкого спектру застосування як математичних методів, так і методів соціологічних досліджень: опитування, спостереження, експеримент, що практично вилучені при аналізі тільки кількісних показників.

Одним із найдоступніших методів збору інформації в соціологічних дослідженнях $\epsilon$ анкетне опитування. В основі анкетного опитування полягає спеціальна технологія, що базується на анкеті. Анкета є одним з основних інструментів визначення думки користувачів про послуги бібліотеки. Анкетування - це 
письмове звернення 3 питаннями до сукупності людей і одержання відповідей 3 проблеми дослідження. Ціль анкетування - отримати зовнішні дані від самих користувачів для виявлення рівня якості обслуговування, визначення ефективності та корисності послуг, які надаються бібліотекою. Анкетування широко використовується в конкретних соціологічних та бібліотекознавчих дослідженнях. Одна з найважливіших переваг методу анкетування - універсальність. Для бібліотекознавчих досліджень велику цінність має і така якість анкетування, як масовість. В той же час серйозним недоліком анкетування $є$ односторонність комунікативних зв'язків, вплив суб'єктивних факторів і відсутність контролю за процесом заповнення і повернення анкет. Значна кількість анкет виявляється бракованими, респонденти ухиляються від відповідей на складні запитання, підвищена частота варіантів відповідей «не знаю», «важко відповісти», частина питань анкети виявилась не зрозумілою для респондентів.

Після пробного анкетування для запобігання вищезазначених недоліків, визначились основні вимоги до складання анкети та їі заповнення. Будь-яка анкета повинна мати назву, звернення, інструкцію щодо заповнення, в якій обумовлюються цілі, завдання опиту, мотивується необхідність заповнення опитувального листа, акцентується увага на більш повне, щире заповнення, гарантується анонімність, вказується коли, куди і кому здати опитувальний лист, висловлюється подяка за участь в анкетуванні. Вручаючи анкету респондентові, необхідно прослідкувати, щоб він іiі переглянув, з'ясував усі незрозумілі йому моменти, а вже потім приступав до заповнення.

Питання в анкетах виділяються у змістовні блоки. Перші запитання повинні бути легкими, розминочними. Далі розташовуються основні питання, контрольні. Завершується анкета питаннями соціально-демографічного плану. Обов'язковими повинні бути питання стосовно віку, статі, освіти. Значна увага приділяється естетичному оформленню анкети та зручності її обробки.

Під час здійснення самої процедури опитування важливо добитися повного контакту з респондентом, бути коректним, уважним, попереджувальним. Слід пояснити людині, чому звернулись саме до неї. Однак опитуваному не можна дозволити втягнути себе до дискусії, особливо з проблем, які з'ясовуються через анкету. Отримавши заповнену анкету, опитувачу слід іiі бігло переглянути i обов'язково подякувати за роботу тому, хто іiі заповнював. Час на заповнення анкети не повинен перевищувати 45 хвилин.

Слід відзначити, що кожне дослідження завжди вимагає розробки нової анкети, яка б відповідала конкретним цілям і завданням, специфіці, місцю і часу проведення дослідження, постійно змінюваній соціокультурній ситуації. Тому використання анкет інших досліджень без переробки є неприпустимим.

Необхідно враховувати, що анкета повинна відповідати темі дослідження, завданням та гіпотезі, визначеним у програмі дослідження. Кожне запитання, що формулюється для анкети, повинно «працювати» на виконання окремого завдання або перевірку конкретної гіпотези. Кількість запитань в анкеті знаходиться в прямій залежності від кількості і складності поставлених в програмі дослідження завдань та сформульованих гіпотез. 
Після того, як складено перелік майбутніх питань анкети, необхідно визначити порядок їх розташування. Місце кожного питання в анкеті залежить від його змісту, будови, складності, виконуваних функцій.

Існують дві основні форми питань в анкеті - відкриті і закриті. Відкрита форма питання найчастіше застосовується тоді, коли вивчається нова проблема, щоб дати опитуваним максимальну свободу у відповідях. Результати обробки цих відповідей використовують для побудови закритих питань в подальших дослідженнях за аналогічною тематикою.

На практиці частіше використовується закрита форма питань, тому що вона легко піддається обробці. Крім того, на такі питання респондент відповідає охочіше і швидше. Але не можна завжди використовувати лише закриті питання. Вони мають ряд недоліків, а саме: перелік готових відповідей може нав'язувати респондентові думку дослідника, не завжди можна скласти повний перелік можливих відповідей (він може бути надмірно великим).

За змістовним навантаженням розрізняють основні і неосновні (додаткові) питання. Саме основні питання повинні розкривати тему дослідження. Але додаткові питання не менш цікаві, вони надають дані про респондента, допомагають отримати більш широке уявлення про коло інтересів читача (якщо вивчається читач бібліотеки).

Додаткові питання стоять на початку і в кінці анкети. Це відповідає одному 3 головних правил побудови опитувального листа: спочатку повинні бути легкі для респондента питання, які допомагають встановити з ним психологічний контакт. Тому ці питання можуть бути неосновними і навіть взагалі не мати значення для дослідника. Відповідаючи на них, користувач повинен поступово увійти в проблематику дослідження. Завершуватись анкета повинна також легкими питаннями, які знімають психологічне навантаження.

Отже питання може виконувати різні функції в залежності від місця його розташування в анкеті і взаємозв'язку з іншими питаннями.

За виконуваними функціями розрізняють інформативні, контактні, функціонально- психологічні питання. Одне питання може виконувати декілька функцій одночасно. В нескладних дослідженнях з короткими анкетами всі питання, звичайно, інформативні (всі обробляються).

Іноді виділяється частина респондентів і декілька питань анкети адресується лише їй. Цьому слугують питання-фільтри. I тоді одне питання $є$ питанням фільтром для іншого. Тому перш ніж спитати, чи є читач респондентом, логічно дізнатися, чи користується він взагалі бібліотекою.

Під час оформлення анкети слід звернути також особливу увагу на такі моменти:

- Не ставити запитання, якщо вас не цікавить відповідь. Завжди керуватися загальною метою дослідження. Уникати сторонніх питань, бо вони розбивають анкету і роблять ії менш привабливою для респондентів. Крім того, вони збільшують необхідний для аналізу анкети час.

- Ставити лише такі запитання, на які можна реалістично і чесно відповісти. Не змушувати респондента давати неточну інформацію. Зокрема це стосується відкритих запитань. 
- Ставити лише такі запитання, до яких користувач підготовлений. Уникати питань, які можуть видатися респонденту важкими. Особисті запитання (наприклад, стать або вік) краще ставити останніми.

- Цікавитися лише тією інформацією, яку не можуть надати інші джерела. Тому що чимало дослідницьких і статистичних даних публікуються.

- Віддавати перевагу конкретним, а не загальним питанням. Уникати подвійних питань типу: «Вам би сподобалося, якби було більше книжок і був тривалішим термін користування ними?» Це різні речі, і їх треба розглядати окремо. Якщо їх поставити разом, це створить труднощі в аналізі.

- Запитання анкети мають бути коректними, простими і зрозумілими. Необхідно уникати запитань - «подарунків» типу: «Вам би сподобалося якби бібліотека працювала у неділю?» Навряд чи респондент відповість «ні», навіть якщо він чи вона не збираються користуватися таким видом послуг. Краще, хоча і витіюватіше, запропонувати набір варіантів, наприклад: «Бібліотека планує працювати і у вихідні дні». Якщо це станеться, ви віддали б перевагу якому розкладу? (наводяться варіанти режиму роботи бібліотеки та варіанти надання послуг, які обмірковує бібліотека).

- Звертати увагу на те, що респондент може відчувати наявність підтексту у запитанні. Наприклад, дослідження, яке стосується послуг, що не дуже широко використовуються в бібліотеці, але є дуже цінними для тих, хто все ж таки ними користується, може бути сприйняте користувачами як ознака того, що ці послуги будуть скасовані. Результатом можуть стати відповіді, які вибивають з колії.

У соціологічному досліджені важливо визначити обсяг вибірки, тобто число опитуваних.

Усі соціальні об'єкти, що вивчаються, утворюють генеральну сукупність. Як генеральну сукупність можна розглядати користувачів бібліотеки, бібліотекарів бібліотеки.

У більшості випадків великий розмір або мінливість генеральної сукупності не дозволяє проводити суцільне опитування. Тому застосовують вибірковий метод. Ідея його проста. Треба взяти невелику частину об'єктів генеральної сукупності (вибіркову сукупність), яка б у мініатюрі була спроможна відобразити всі основні характерні ознаки, що підлягають дослідженню.

Принциповою проблемою вибіркового методу є неможливість пересвідчитися у тому, що вибірка являє собою зменшену копію оригіналу, оскільки не можна зіставити усі показники вибіркової та генеральної сукупності. Тому вибіркова сукупність - це лише ймовірна модель.

Властивість вибіркової сукупності відтворювати, моделювати типові характеристики об'єкту дослідження називається репрезентативністю.

Вибіркова сукупність для простого ймовірного відбору вираховується за такою формулою:

$\mathrm{n}($ вибіркова сукупність $)=\frac{N}{0,0025 N+1}$, де $\mathrm{N}$ (генеральна сукупність)

Наприклад, якщо проводиться опитування користувачів окремого відділу 
бібліотеки з кількістю фактично обслугованих користувачів - 3000, для повної достовірності даних, що будуть отримані, необхідно опитати 353 чоловіки.

$$
\mathrm{n}=\frac{3000}{0,0025 * 3000+1} \quad \mathrm{n}=353
$$

353 складає 11,8 \% від 3000, які прийняли за 100\%., або відсоток n (вибіркової сукупності) дорівнює 11,8\%. від N (генеральної сукупності). Слід пам'ятати, що для науково розроблених узагальнених висновків найменша сукупність об'єктів, які вивчаються, не може бути менша за 25 одиниць.

Як свідчить досвід професійних соціологів для пробних дослідів достатньою $\epsilon$ вибірка обсягом 100-250 чоловік. У масових опитуваннях, якщо величина генеральної сукупності складає менше 5000 чоловік, достатній обсяг вибіркової сукупності - не більше 500 респондентів, якщо ж обсяг генеральної сукупності 5000 чоловік і більше, то необхідно опитати $10 \%$ усієї сукупності, але не більше 2000-2500 респондентів.

Під час підготовки розрахунків необхідно враховувати вибраковки (Макс. 5\%). Наприклад, при підготовці анкетування 200 користувачів доцільно опитати 210 респондентів (10 «позапланових» передбачається на випадок помилок: невірно заповнені, не на усі питання дані відповіді).

При розробці анкет науковою бібліотекою ДонНУЕТ були використані зразки анкет університетських бібліотек Великої Британії, які наведені у книзі Д. Кроуфорда «Оцінка бібліотечних й інформаційних послуг» та індикатори вимірювання ефективності роботи бібліотеки, представлені у «Положенні 3 якості функціонування бібліотеки університету». В анкетуванні приймали участь користувачі, що відвідували бібліотеку у визначені дати. Після пробного анкетування удосконалювалася форма анкет.

На основі вищевикладеного, розроблено анкети для користувачів наступних підрозділів бібліотеки: відділу періодики (ВП); абонементу обслуговування науковою літературою; сектору нормативних документів (сектор НД); залу каталогів; читального залу наукової і навчальної літератури (ч/з НіНЛ); читального залу електронних документів (ч/з ЕД). Розроблені анкети обговорені на робочих секціях та затверджені Радою бібліотеки.

В результаті аналізу одержаних відповідей на запитання анкети встановлено тип користувачів: це переважно студенти - 94,9\%, абсолютну більшість складають студенти денного відділення $-85,7 \%$. Аналізуючи анкети, можна зробити висновок, що більшість респондентів - 89\% - активна категорія користувачів. Це дає можливість стверджувати, що отримані результати анкетування об'єктивні. На питання анкети, чи задовольняють години роботи бібліотеки 96,9\% респондентів відповіли позитивно. Дослідження довело що 73 \% користувачів бібліотеки звертаються до бібліотеки для одержання нових знань, $10-13 \%$ - для одержання даних для наукових досліджень, 78-90 \% опитаних робота бібліотеки задовольняє, але $10-22 \%$ не відповіли на це питання анкет. I це визиває занепокоєння.

Домінуючим стимулом візитів до бібліотеки $є$ самостійне навчальнонаукове дослідження студентів: реферат, курсова, дипломна робота, $-70,4 \%$ 
респондентів. На питання щодо пошуку інформації 85 \% опитаних відповіли, що користуються електронним каталогом. На питання «До яких носіїв інформації найчастіше ви звертаєтесь» $71 \%$ респондентів відповіли що до електронних, $29 \%$ до друкованих. 98 \% користувачів бібліотеки використовують фонд повнотекстових документів та БД, створені бібліотекою. Кожен другий опитуваний звертається до Інтернет - ресурсів.

$37 \%$ опитуваних Інтернет допомагає задовольнити потреби навчання, 24\% використовують Інтернет для наукової роботи, дозвілля - 20\%, самоосвіти 19\%. Дані про кількість документів, використаних респондентами: до 5 книг одержали $23,5 \%$, до 10 - 35,7\%, до 20 - 30\%, більше 20 - 10,2\% - свідчать про необхідність мати широке коло назв видань у фондах бібліотеки.

Аналізуючи відповіді на запитання анкети щодо способу та швидкості надання документів, можна отримати показник ефективності, який визначає швидкість надання послуги. 3 фонду читальних залів література видається дуже швидко - до 5 хвилин були обслуговані 86 \% респондентів. Приймаючи до уваги той факт, що користувачі при цьому отримують від 10 до 20 документів, можна стверджувати, що надання послуг в читальних залах $€$ ефективним.

3 результатів анкетування видно, що користувачі читальних залів віддають перевагу усному замовленню, яке поєднується 3 пропозицією книг бібліотекарем. Це відмітили 85 \% респондентів. Відповідь на запитання Чи задовольняє Вас консультативна допомога персоналу бібліотеки стала логічним продовженням відповідей на попередні запитання анкети. 89,8 \% респондентів високо оцінили рівень консультативної допомоги персоналу бібліотеки. Відповіді на питання Які Bамі пропозичї щодо покращання діяльності роботи бібліотеки, в основному, торкались проблеми оснащення засобами комп'ютерної та копіювальної техніки.

Моніторинг рівня документально-ресурсного забезпечення користувачів бібліотеки виявив, що збільшеня кількості електронних документів, станом на 01.01.10 р. вони налічують 9767 примірників, спричинило збільшеня звернень до е-документів: на протязі року до е-документів звернулось $89 \%$ користувач , запрошено 390 тис. е-документів, у 2008 році було запрошено 127 тис. едокументів, кількість звернень до е-документів у 2009 році збільшилась у три рази і складає $47 \%$ від загальної книговидачі бібліотеки. Фонд е-документів бібліотеки повністю забезпечує навчальний процес університету.

Важливою умовою впровадження системи якості в роботу бібліотеки є постійне підвищення кваліфікації бібліотечних працівників. Працівники бібліотеки повинні бути готовими до тих змін, які неминуче відбуваються в процесі впровадження системи менеджменту якості в бібліотечні процеси та технології. Кожен співробітник бібліотеки повинен розуміти, як його робота впливає на задоволення запитів користувачів бібліотеки, на імідж бібліотеки, в яких процесах він приймає участь, як ці процеси впливають на результати роботи бібліотеки в цілому і що треба зробити для того, щоб покращати результати своєї роботи. Бібліотекар виступає представником інтересів всіх елементів бібліотечної системи, розпорядником взаємовідношень між усіма ії компонентами. Взаємодія 
всіх елементів системи повністю залежить від співробітників бібліотеки, їх впливу на процеси.

Бібліотека ДонНУЕТ постійно працює над підвищенням якості інформаційної підтримки навчального процесу університету, використовуючи комп’ютерні технології. Але впровадження комплексної системи менеджменту якості в діяльність бібліотеки дозволить підвищити рівень обслуговування користувачів, запропонувати нові види інформаційних послуг з використанням інноваційного інструментарію, які не тільки відповідають вимогам користувачів бібліотеки, але i випереджують в якісних характеристиках їх очікування, швидко адаптуються до змін їх потреб і переваг.

Якість для бібліотеки - це орієнтир на інтереси користувачів, постійне задоволення їх інформаційних потреб відповідно до навчальних, наукових та професійних запитів, поліпшення якості і ефективності бібліотечних послуг. 


\section{2. СИСТЕМА МЕНЕДЖМЕНТУ ЯКОСТІ В БІБЛІОТЕЦІ ТЕХНІЧНОГО УНІВЕРСИТЕТУ}

Розвиток світової економіки на сучасному етапі свідчить, що якість продукції та послуг, стала визначальним чинником успішної господарської діяльності підприємств та організацій. В останнє десятиріччя у сфері якості сталися докорінні зміни, що адекватно відбивають прискорення технічного розвитку промисловості та індустрії. На сьогоднішній день стала актуальною проблема забезпечення якості освіти. Управління освітою, зокрема ії якістю складний, багатогранний і нелінійний процес, який повинні постійно координувати й корегувати суб'єкти управління, відповідно до соціально педагогічних умов його функціонування.

Інформаційне забезпечення $є$ важливою ланкою навчального процесу будьякого вищого навчального закладу. Цю роль традиційно виконує бібліотека, наскільки іiі інформаційний простір відповідає запитам користувачів, настільки успішною стає навчальна та науково-дослідницька робота закладу. Надійність процесу обслуговування в бібліотеці визначається не тільки кількістю послуг, що надаються, а й тим, наскільки повно і якісно вони задовольняють інформаційні потреби, отже забезпечення системи якості в бібліотеці є одним із головних чинників у створенні якісної освіти.

Такою системою якості для бібліотек вищих навчальних закладів може стати система менеджменту якості, орієнтована на міжнародні стандарти [1]. Цей стандарт передбачає набір показників якості, тому за метою роботи ставиться впровадження елементів системи менеджменту якості в один із головних відділів бібліотеки і розробка технологічної мапи процесів, які мають місце у цьому відділі зокрема і в бібліотеці в цілому.

На сьогоднішній день університетські та інші наукові бібліотеки у всьому світі усвідомлюють необхідність в наявності інструментів для ефективного управління роботою, що в свою чергу супроводжується істотними змінами які вплинули і на організаційну структуру бібліотек:

- бібліотеки вищих навчальних закладів стали використовувати комп'ютери;

- у всьому світі значна кількість матеріалів пропонується в електронній формі, і вони повинні бути доступні для користувача;

- природні ресурси поступово виснажуються, і фонди, так само як і традиції організації бібліотечного обслуговування, повинні адаптуватися до вимог, які змінюються; необхідно знайти інструменти для ефективного використання ресурсів;

- збільшується обсяг інформаційних ресурсів, доступних через глобальну мережу;

- постійно зростає значення зв'язків з громадськістю.

Бібліотекам потрібні засоби для ознайомлення громадськості і публікації результатів своєї діяльності.

Поняття якості поступово розвивалося - від контролю та експертизи продукції до більш широкого погляду, орієнтованого на аналіз наданих сервісів, і всю організаційну структуру [2]: 
- Якість бібліотечно-інформаційної послуги - сукупність властивостей і характеристик (параметрів) послуги, що забезпечують ії здатність задовольняти певні (обумовлені або передбачувані) потреби користувача відповідно до його запитів і очікувань;

- Якість бібліотечно-інформаційного обслуговування - сукупність властивостей (параметрів) послуг, процесів і умов їх надання, що забезпечують задоволення відповідних потреб користувачів в даному виді обслуговування.

Якість бібліотечно-інформаційних послуг є головною складовою якості бібліотечного обслуговування в цілому, тому виділення обгрунтованих стандартизованих показників рівня якості і методів ідентифікації відповідності набуває актуального значення для вітчизняних бібліотечних установ. Ефективність профільної стандартизації може бути досягнута завдяки впорядкуванню, систематизації, типізації, уніфікації, взаємозамінності і оптимізації ії об'єктів. Важливе місце в бібліотечно-інформаційній практиці посяде так звана параметрична стандартизація - стандарти параметрів, що характеризують основні показники якості послуг.

Якість для бібліотеки це добре налаштована внутрішня технологія і механізм управління, націлені на інтереси користувача і задоволення його інформаційних запитів. Це означає, що однією з головних задач вищих навчальних закладів на сьогоднішній день $\epsilon$ створення системи якості інформаційнобібліотечних послуг, яка ефективно діє і постійно вдосконалюється, що впливають на підготовку високопрофесійних фахівців, на якість освітнього і науково-дослідного процесів у вищих навчальних закладах.

Під системою менеджменту якості в бібліотеці розуміють концепцію управління бібліотекою, що представляє сукупність дій персоналу бібліотеки, відповідає поставленим, на визначеному періоді часу вимогам різних категорій читачів, до якості бібліотечно-інформаційних послуг, а також якості сервісу, способам та формам надання інформації $[3,4]$.

Вибір стандарту або моделі, за яким створюється система менеджменту якості, залишається за вищим навчальним закладом, проте будь-яка бібліотека в своїй роботі самостійно може використовувати окремі елементи різних методів для поліпшення і оптимізації своєї діяльності.

Існують різні способи, за допомогою яких можна впроваджувати систему менеджменту якості і реалізувати вимоги стандарту за якістю. У кожному конкретному випадку бібліотека сама вибирає 3 них той, який найкращим чином відповідає іiї особливостям і прийнятим методам роботи.

Підготовка персоналу до сприйняття нової системи, до тих змін, які неминуче будуть відбуватися при підготовці і створенні системи менеджменту якості $€$ важливим етапом і заставою успішного впровадження системи. Кожний співробітник повинен усвідомити свою роль у досягненні цілей бібліотеки, як поточних, так і стратегічних, повинен зрозуміти, яким чином його робота впливає на задоволеність користувачів, в яких процесах він бере участь, в чому вимірюється результативність його роботи, що він повинен зробити, щоб ця результативність збільшилася. I щоб співробітники одержали відповіді на ці 
питання, важливо провести в колективі мотиваційні семінари. Причому, такі мотиваційні семінари повинні повторюватися 3 певною періодичністю, і охоплювати в обов'язковому порядку всіх співробітників i, головне, забезпечувати їх участь у формуванні і безперервному вдосконаленні системи менеджменту якості. Співробітники повинні дізнатися, який шлях їм належить пройти, що необхідно зробити, які зміни в роботі їх чекають, і найголовніше - у них повинне бути бажання все це виконати.

Одним з самих трудомістких етапів створення системи менеджменту якості $\epsilon$ документування. Результативність і ефективність системи багато в чому залежить від того, наскільки вона якісно документована. Документація системи менеджменту якості - це документи, які визначають побудову, функціонування і поліпшення системи. Повнота і характер документування повинні відповідати законодавчим і регламентуючим вимогам, потребам і очікуванням користувачів та інших зацікавлених сторін, розмірам і видам діяльності бібліотеки, складності процесів і їх взаємодії між собою, компетентності персоналу. Опис процесів i операцій дозволяє скласти основу для документування системи менеджменту якості [5].

Для впровадження елементів системи менеджменту якості в бібліотеці технічного університету, спочатку необхідно розглянути та проаналізувати структуру бібліотеки.

Проаналізуємо структуру бібліотеки технічного університету [6, 7].

Будь-яка бібліотека технічних університетів складається з відділів:

Дирекція бібліотеки

Внутрішні відділи бібліотеки:

- відділ комплектування - здійснює планування комплектування фонду бібліотеки;

- відділ наукової обробки документів та організації каталогів - забезпечує складання та редагування бібліографічного опису документів;

- відділ зберігання фондів - забезпечує зберігання та списання літератури;

- відділ електронних ресурсів - здійснює комплектування фонду електронної бібліотеки повнотекстовими виданнями;

- відділ або служба технічної підтримки та програмного забезпечення;

Відділи обслуговування:

- відділ реєстрації користувачів - здійснює реєстрацію та облік користувачів бібліотеки технічного університету в електронній базі даних, виготовляє пластикові читацькі картки та посвідчення для працівників університету;

- відділ наукової літератури - здійснює видачу користувачам наукової літератури;

- відділ навчальної літератури - здійснює видачу користувачам літератури, яка необхідна під час навчального процесу;

- відділ художньої літератури - забезпечує користувачів літературнохудожніми творами $з$ фонду бібліотеки та проводить культурно-виховну роботу серед студентської молоді

- науково-бібліографічний відділ - забезпечує довідково-інформаційне об- 
слуговування користувачів, що включає: видавання довідкової, офіційної літератури та видань за освітянською тематикою для підготовки різних письмових робіт студентів та науково-педагогічних працівників, здійснення добору необхідної літератури певної тематики для самостійної роботи студентів, виконання різних довідок та консультацій за запитами користувачів, обслуговування індивідуальних абонентів 3 керівництва ВНЗ тощо;

- відділ літератури іноземними мовами - здійснює обслуговування усіх користувачів, яким потрібна література іноземними мовами. Особливу увагу приділяють користувачам-студентам, що є іноземними громадянами;

- відділ читальних залів включає чотири традиційних читальних зали:

о читальний зал наукової та навчальної літератури (ЧЗ №1) - забезпечує користувачів науковими та навчальними книгами технічної та природознавчої тематики;

о читальний зал соціально-економічної літератури (ЧЗ №2) - забезпечує студентів та викладачів соціально-економічною літературою;

о читальний зал науково-технічних періодичних видань (Ч3 №3) - надаються для використання журнали технічного та природознавчого профілю;

о читальний зал спеціальних видів літератури (ЧЗ №4) - зберігається та надається для використання дисертаційні роботи та автореферати, дипломні роботи студентів за останні 5років, звіти з НДР.

Типова схема бібліотеки технічного університету наведена на рисунку 1.

Для розуміння процесів, які мають місце в бібліотеці, необхідно створити технологічну мапу роботи бібліотеки технічного університету.

Технологічну мапу розробляємо на базі положення про бібліотеку і вона наведена на рис. 2

Для впровадження системи менеджменту якості в бібліотеці обираємо один iз внутрішніх відділів, а саме відділ електронних ресурсів. Цей відділ здійснює комплектування фонду електронної бібліотеки повнотекстовими виданнями, збереження та захист електронної бібліотеки, а також контроль за електронними ресурсами [7].

Основними функціями відділу є:

- Формування, архівація та використання:

о електронних інформаційно-бібліотечних ресурсів на основі автоматизованої інформаційної бібліотечної системи (АІБС) «УФД/Бібліотека»;

о бібліографічної бази даних «Електронний каталог»;

о повнотекстової бази даних «Електронна бібліотека»;

- Електронна доставка документів. 


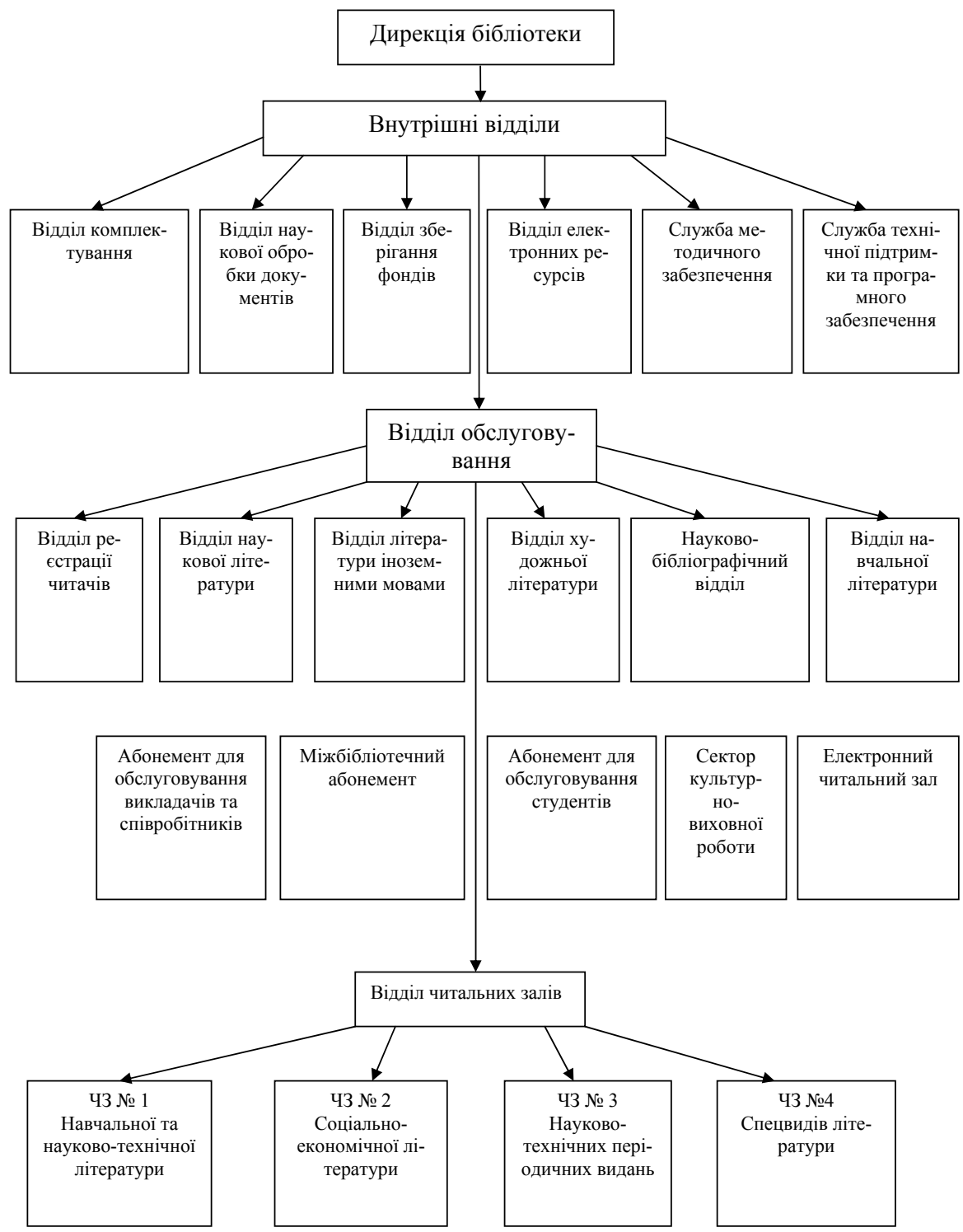

Рисунок 1. Схема бібліотеки технічного університету 


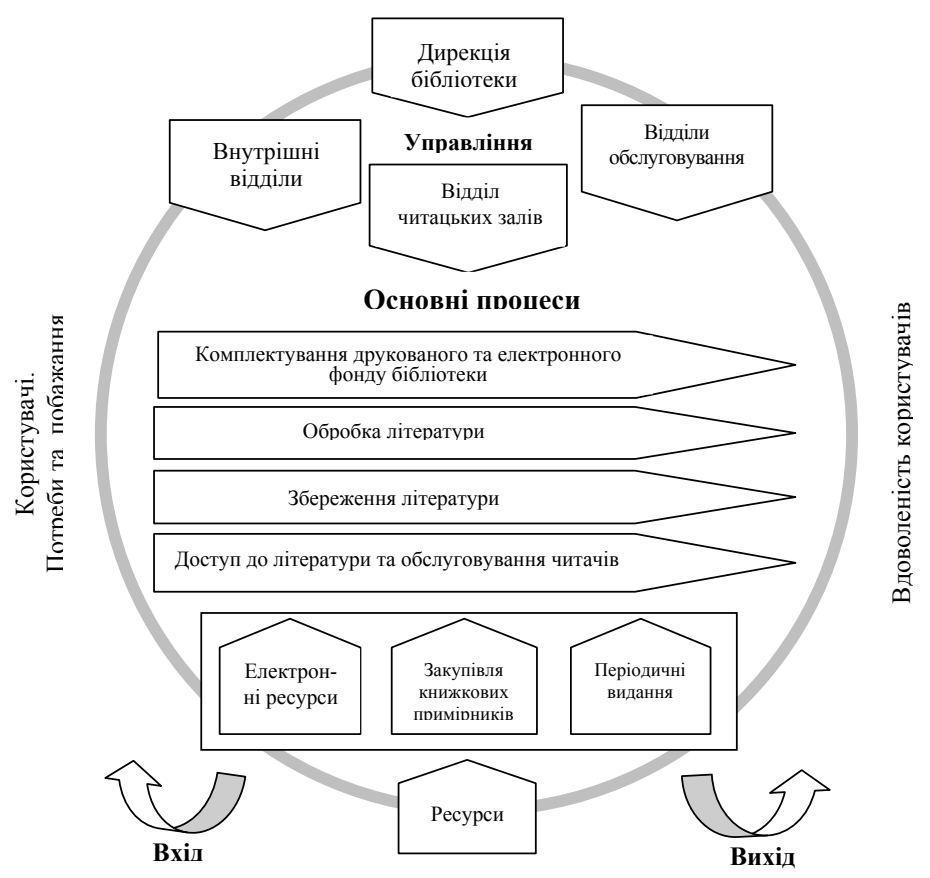

Рисунок 2. Технологічна мапа роботи бібліотеки технічного університету

Головна задача відділу - це комплектування фонду електронної бібліотеки повнотекстовими виданнями.

Поповнення фонду здійснюється в декілька етапів:

\section{Етап 1- Підготовчий.}

Перед приєднанням електронної версії документа необхідно виконати наступні процедури:

а) перевірити електронний документ за такими показниками якості - відповідність допустимим форматам (документ Word, HTML-документ, стандартний текст, формати PDF, DJVU та інші), читабельність тексту, наявність всіх сторінок в документі, порядок чергування сторінок, правильність їх орієнтації.

б) якщо документ багатофайловий (містить підкаталоги, два і більше файлів), необхідно його заархівувати.

Операцію архівування здійснюємо в такій послідовності:

- переносимо всі файли для архівації в окрему папку;

- запускаємо архіватор WinRar;

- у вікні архіватора виділяємо необхідну папку;

- натискаємо кнопку добавити на основній панелі;

- в меню, що з'явилося, вказати ім'я файлу (без пропусків, тільки латинськими літерами); 
У результаті в кореневій папці повинен бути створений архівний файл, що саморозпаковується.

в) провести в системі УФД пошук запису бібліографічного опису документа і перевірити тотожність електронної версії твердій копії.

Якщо опису не існує, його потрібно створити.

Етап 2 - Корегування полів опису.

a) у вікні опису документа заповнити/перевірити всі основні поля опису (якщо документ не має твердої копії, після назви документа в полі «Назва документа» обов'язково включити запис - [Електронний ресурс]);

б) додати анотацію, ключові слова (якщо необхідних ключових слів немає або є якісь доповнення, зауваження по опису полів, то їх потрібно занести у вікні Анотації після тексту для редагування відділом обробки);

в) заповнити поле Примітки.

Етап 3 - Прив'язка електронної копії документа.

У вікні опису документа натискаємо кнопку «Ел», після чого з'являється форма «Електронна копія документу».

а) вибираємо поле Електронна версія документа;

б) ставимо галочку про наявність електронної копії;

в) «Місце збереження документа» вибираємо $<\mathrm{URL}>$;

г) доступ з мережі Інтернет або в локальній мережі.

Ім'я файлу документа складається з двох складових - шляху до документу та імені файлу.

Далі, залежно від виду документа розташовуємо документи у таких папках:

Художня література - сюди заносимо літературу російською та українською мовами, зокрема публіцистику, нариси, статті на загальноосвітні теми.

Електронні документи іноземними мовами (всі види документів) - сюди заносимо електронні документи на будь-якій іноземній мові незалежно від виду документації.

Електронні документи російською та українською мовами - сюди заносимо книги, навчальні посібники, технічну літературу, стандарти.

Ім'я складається таким чином:

[Автор(и)] - [Назва] - [Додаткові відомості про назву] - [Місце видання] [Видавництво $-[$ Рік] - [Відомості про видання] - [мова].формат_документа

д) переносимо електронний документ у вказану папку.

е) зберігаємо у вікні параметрів бібліографічного опису документа проведені зміни.

є) проводимо перевірку правильності розміщення електронної версії документа. У результаті, при правильному виконанні всіх операцій з'явиться вікно програми - перегляду, в якому буде запущений документ, або вікно запису файлу на ваше джерело.

У випадку, якщо запускається програма - переглядач, і видається помилка доступу - допущена помилка в імені файлу, імені робочої папки або електронна версія документа не знаходиться по вказаному шляху. 
Наданням доступу до електронних ресурсів займається:

- технічна служба з боку забезпечення якісної роботи, але тільки у локальній мережі бібліотеки (згідно з Законом України «Про авторське право та суміжні права» N 3792-XII від 23 грудня 1993 року із змінами та доповненнями);

- відділи обслуговування (в електронному читальному залі надається доступ до повнотекстових матеріалів (згідно із затвердженими правилами користування ЕлБ);

Описана робота та основні задачі відділу електронних ресурсів в технічному університеті. Тепер на базі задач відділів та описів процесів можна розробляти елементи системи менеджменту якості даного відділу.

На сьогоднішній день набуває поширення електронні версії документів, які на сучасному етапі стають більш доцільніші та зручніші у користуванні. Електронні ресурси $\epsilon$ важливою складовою інформаційного забезпечення навчальновиховного процесу. Вони дозволяють залучити до викладання ресурс Інтернету, що відповідає вимогам часу. Новітні комп'ютерні технології навчання дуже швидко з'являються і застарівають. Використання Інтернету сприяє оперативному впровадженню у практику викладання останніх наукових досягнень та методичних розробок.

Більшість бібліотек лише розпочинають впроваджувати систему менеджменту якості. Одночасне впровадження системи менеджменту якості в усіх відділах потребує значних зусиль, то доцільно розпочати з окремого підрозділу [7].

Оскільки відділ електронних ресурсів на сьогоднішній день став дуже важливим, то впровадження елементів системи якості розпочнемо 3 нього.

Відділ електронних ресурсів наукової бібліотеки здійснює комплектування фонду електронної бібліотеки повнотекстовими виданнями, та забезпечує їх збереження та захист.

Наведемо короткі характеристики процесів, які відбуваються у відділі електронних ресурсів.

Формування електронної бібліотеки створюється за допомогою процесів:

- сканування - здійснюється сканування документу за допомогою сканера, та переведення його в електронний вид допустимого формату (документ Word, HTML-документ, стандартний текст, формати PDF, DJVU);

- документ може бути одержаний за договором обміну фондами електронних ресурсів з іншими організаціями, бібліотеками, учбовими закладами;

- отримання документу з мережі Інтернет;

- отримання документу з видавництва;

- на етапі перевірки допустимого формату перевіряємо документ за такими показниками якості - відповідність допустимим форматам (документ Word, HTML-документ, стандартний текст, формати PDF, DJVU i інші);

- створюється запис документу в базу даних електронної бібліотеки;

- створюється бібліографічний опис документа;

- визначається місце розташування документа;

- перевірка правильності розміщення електронного документа. 
На першому етапі впровадження елементів системи менеджменту якості розробимо технологічну мапу процесів, що відбуваються у відділі, на основі положення про електронну бібліотеку, яка зображена на рис. 3.

Розглянувши систему роботи бібліотеки технічного університету, процеси, які в ній відбуваються були розроблені елементи системи менеджменту якості у вигляді технологічних мап цих процесів. В подальшому планується розробити інші елементи якості, з метою впровадження системи менеджменту якості в цілому.

Розпочато впровадження елементів системи менеджменту якості з відділу електронних ресурсів, тому що електронні версії документів, на сучасному етапі стають більш доцільніші та зручніші у користуванні. Для кожного процесу, який відбувається у відділі необхідно визначити показники якості, за якими буде здійснюватися оцінка. Для кожного показника якості необхідно створити шкалу оцінки, обрати метод оцінювання, здійснити збирання даних, зробити статистичну обробку зібраних даних, за їх результатами оцінити якість процесу і створити план по подальшому вдосконаленні певного процесу бібліотеки технічного університету.

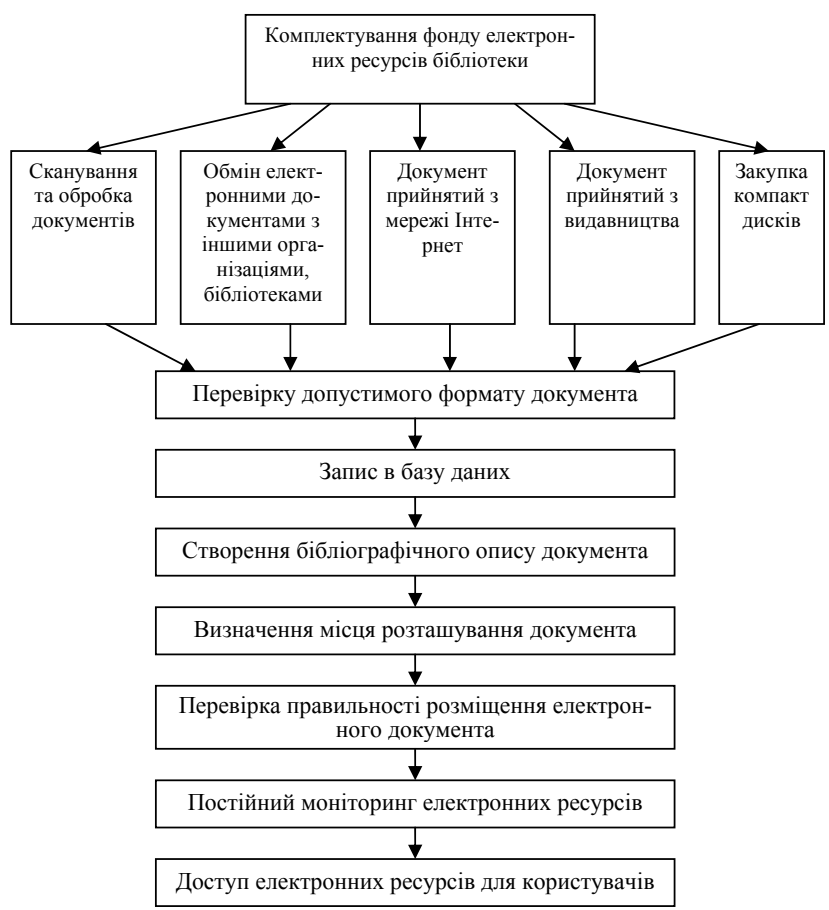

Рисунок 3. Технологічна мапа процесів, що відбуваються у відділі електронних ресурсів. 


\section{СПИСОК ДЖЕРЕЛ}

1. ДСТУ ISO 9001-2001 «Системи управління якістю. Вимоги»[Текст]. -К.: Держстандарт Украӥни, 2001. - 26 с.

2. Полл, Р. Измерение качества работы. Международное руководство по измерению эффективности работы университетских и других научных библиотек [Текст] / Р. Полл, П. Бокхорст-М. : 2001.- 152 c.

3. Суслова, И. М. Основы библиотечного менеджмента [Текст]: учебн. - практ. пособие / И. М. Суслова. - М.: Либерия, 2000. - 232 с.

4. Ахмадова, Ю. А. Система менеджмента качества библиотек [Текст] / Ю. А. Ахмадова. - СПб.: Профессия, 2007.- 264 с.

5. Чуприкова, Н. Т. Практические аспекты внедрения системы менеджмента качества в библиотеке университета [Електронний ресурс] / Н. Т. Чуприкова, Н. И. Размарилова ; ГПНТБ России // Библиотеки и информационные ресурсы в современном мире науки, культуры, образования и бизнеса : материаль 12-й международ. конф. «Крым-2005». - Режим доступа: http://www.lib.tru.ru. - Загол. 3 екрану.

6. Ахмадова, Ю. А. Менеджмент качества и библиотека [Текст]: учеб. - практ. пособие / Ю. А. Ахмадова, Е. Я. Галимова. - М.: Либерия, 2007. $-88 c$.

7. Якість функиіонування бібліотечної системи ВНЗ [Текст] : Mатеріали III міжвуз. наук.-практ. конф.- Донецьк, 18-19 жовтня 2007р.: тези доповідей / [редкол.: А. А. Садєков (відп. ред.) та ін.]. - Д.: ДонНУET, 2007. - 222 C. - В надзаг.: Міністерство освіти і науки України, Донечький начіональний університет економіки і торгівлі імені Михайла Туган-Барановського 



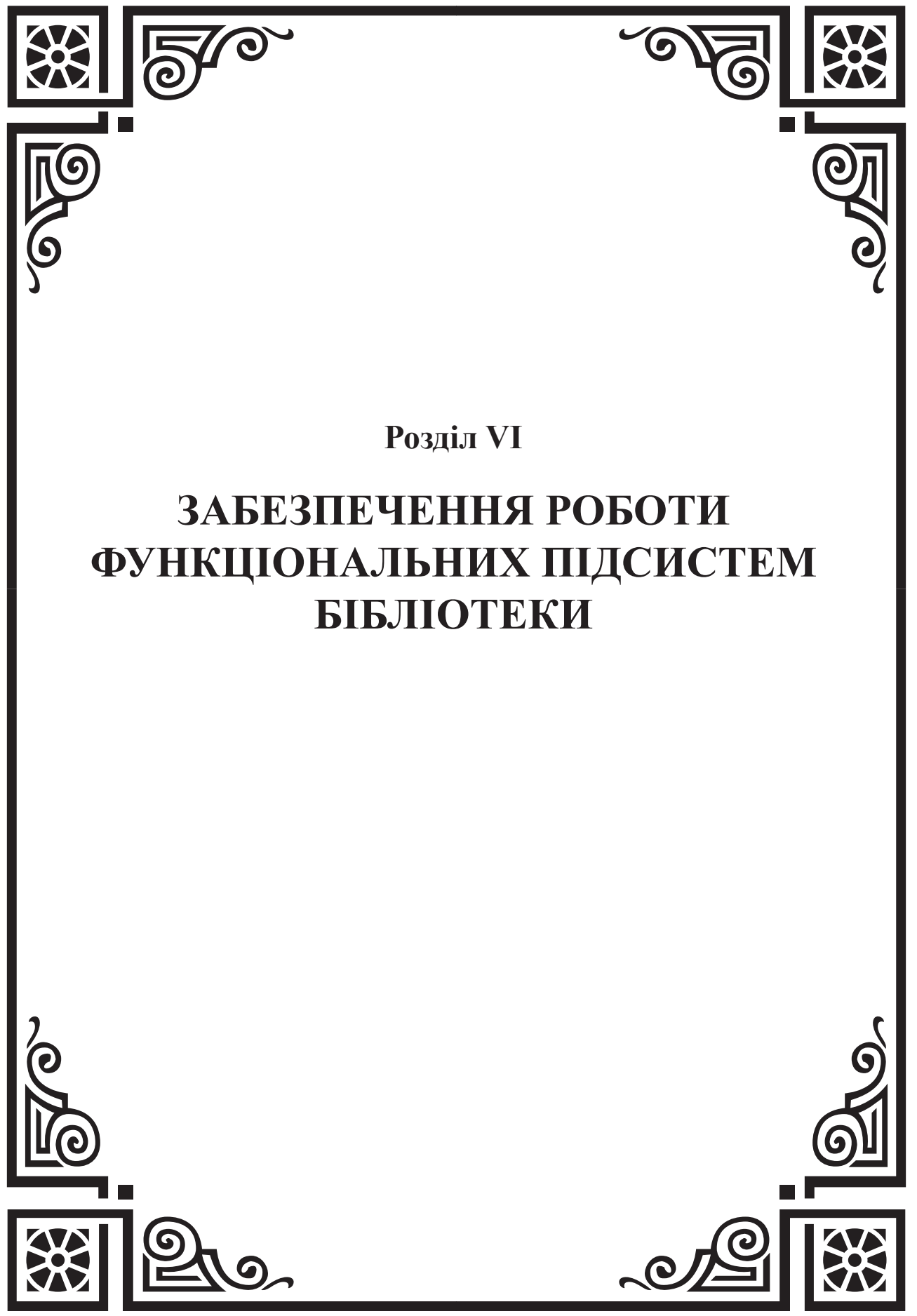




\section{1. ЛИНГВИСТИЧЕСКОЕ ОБЕСПЕЧЕНИЕ ЭЛЕКТРОННОГО КАТАЛОГА: ОПЫТ И ПРОБЛЕМЫ}

Современное развитие образования требует создание единой многопрофильной информационной системы учебных заведений, которая должна стать составной частью образовательной среды. Такая система должна включать в себе центральную электронную библиотеку, сеть филиалов и сеть рабочих мест, где субъекты образовательного процесса смогут получать необходимую им информацию.

Автоматизированная библиотечная сетевая информационная система - это лишь шаг на пути к созданию полноценной электронной библиотеки - сначала локальной, а затем и распределенной. Электронные библиотеки должны создаваться, как распределенная и интернациональная система. Сервисы, предоставленные персоналом электронных библиотек, взяты из учебного процесса конкретного учебного заведения, а значит, могут существовать как автономные части содружества электронных библиотек и учебных заведений дистанционного образования, оставаясь при этом очень важной частью образования.

Перед нами была поставлена задача создания электронного каталога (ЭК), который бы предоставлял пользователю максимально комфортные условия для проведения эффективного поиска необходимой информации по тематическим запросам и был бы совместим с лингвистическим обеспечением ЭК других библиотек с целью обмена данными. Лингвистическое обеспечение необходимо для того, чтобы представить данные в таком виде, который обеспечивает их хранение, поиск по нужным признакам и вывод в необходимой форме.

Вопросы лингвистического обеспечения являются наиболее проблемными и трудоемкими аспектами работы с ЭК. Активное внедрение в практику работы библиотек новых технологий предъявляет к лингвистическому обеспечению высокие требования. Оно находится и должно находиться в состоянии постоянного совершенствования, чтобы представить данные в таком виде, который обеспечивает поиск по нужным признакам и вывод результатов поиска в необходимой форме.

Мы приступили к разработке стратегии лингвистического обеспечения ЭК и других баз данных (БД) после изучения опыта работы ведущих библиотек Украины и стран СНГ. В соответствии с избранной стратегией усовершенствования электронного каталога мы начали с редактирования записей и создания регламентирующей документации. Специалисты четко представляли ответственность за все решения, которые принимаются на любом из этапов в процессе лингвистического обеспечения БД, так как все они взаимообусловлены. При составлении плана работы над ошибками лингвистического обеспечения ЭК принципиально важно грамотно определить алгоритм действий, а рабочую группу сформировать из сотрудников с надлежащим уровнем образования, эрудиции, интеллекта и опытом подготовки. Наша задача усложнялась: ранее при создании ЭК к работе привлекались студенты и сотрудники других подразделе- 
ний; отсутствовали технологические инструкции; записи ЭК трижды конвертировались; недоставало АРМов.

Сотрудниками отдела научной обработки и организации каталогов разработали и опробовали инструкции «Предметизация документов для создания машиночитаемого списка записей предметных рубрик ЭК в процессе автоматизированной обработки документов в АБИС «ИРБИС» НТБ НТУ «ХПИ», «Индексирование документов ключевыми словами в режиме автоматизированной обработки системы «ИРБИС» и «Инструкция по редактированию ЭК». С приобретением техники, новой версии программного обеспечения, усовершенствованием сетевых технологий у библиотеки появилась возможность активизировать работы по усовершенствованию ЭК.

В 2003 году приобретена, а с 2004-го года внедрена новая система «ИРБИС - 32», удовлетворяющая требования к системам автоматизации библиотек. Сразу же возникла необходимость начать редактирование библиографических записей ЭК, конвертированных из предыдущих программ в «ИРБИС». Процесс редактирования разделен на несколько этапов:

Первый этап - редактирования закладки «Систематизация», в которой были отредактированы индексы УДК/ББК, авторский знак, систематический шифр и дополнены новые поля в закладке шифр документов в БД, раздела знаний, индексов ГРНТИ и ключевых слов. Это сразу же позволило пользователям осуществлять комплексный поиск необходимых документов в ЭК.

Второй этап - использование «Программы проверки БД системы «ИРБИС» Томского университета систем управления и радиоэлектроники». Эта программа разработана в рамках проекта, проводимого в Муниципальной информационной библиотечной системе города Томска, и предназначена для определения и редактирования дублетных и иных данных в соответствии со значением единичных полей (подполей) или их комбинаций и представляет собой средство редактирования записей ЭК, выполненных в системе «ИРБИС».

Программа позволяет сравнивать несколько записей с их последующим редактированием, переносить недостающие сведения из одной записи в другую. Для выбора алгоритма проверки БД существует форма, в которой возможно редактировать и добавлять свои варианты проверки записи в БД.

При работе корректора иногда возникает задача копирования данных из одной записи в другую, используя буфер обмена. Классический пример этому редактирование дублетных записей. В результате требуется перенести незначительную отличительную информацию из одной записи в другую, а затем удалить дублетную. С помощью этой программы удалены лишние пробелы и пустые алгоритмические коды.

Третий этап - использование функции глобальной корректировки, которая служит для одновременного изменения группы записей БД по специальной форме в соответствии с пакетным заданием. Независимо от способа определения группы записей, подлежащих глобальной корректировке, можно задать диапазон внутренних номеров документов и редактировать записи, которые попадают в данный диапазон. Эту корректировку можно использовать при ре- 
дактировании полей: заголовок, заглавие, индивидуального и коллективного автора, выходные данные, область серии, УДК/ББК, инвентарный номер штрих код и т.д. На текущий момент отредактировано 65000 библиографических записей.

Исправление грамматических $и$ других ошибок, пополнение документов данными о новых поступлениях и другие подобные действия выполняются в режиме корректировки документов по номеру записи в БД или по документам, отмеченным при просмотре результатов поиска.

Проводится корректировка по результатам поиска, причем для поиска нужно задать общий для всех документов набор элементов данных. В практике работы нашей библиотеки хорошо себя зарекомендовал способ «Корректировка по словарю». Такой режим приемлем для словарей: ключевые слова, заглавие, серия, издающая организация, место издания, УДК/ББК и т. д. Считаем необходимым периодически пересматривать словари авторов, заглавий, коллективов, ключевых слов с целью выявления ошибок. Корректировку такого вида целесообразно проводить в режиме глобальной корректировки документов, последовательно просматривая словари, где специалист определит стоящие рядом написания одного и того же значения поискового термина.

При разработке лингвистического обеспечения ЭК мы пришли к выводу, что оно должно обеспечивать одновременное решение, как минимум, нескольких задач: поиска в ЭК; совместимости лингвистических средств (использования в различных БД поисковых образов документов на одном ИПЯ); обмена данными.

Поиск в ЭК. В последние годы количество текстовой информации в электронном виде возросла настолько, что возникает угроза ее обесценивания в связи с трудностями поиска необходимой информации среди множества доступных текстов (1). Обеспечение релевантного поиска - основная цель разработки системы лингвистического обеспечения ЭК, поскольку оно существенным образом влияет на качество поиска.

Классификационные языки, в основном, обеспечивают поиск по запросам отраслевого характера, обладают универсальностью и формализованностью, а вербальные языки - по запросам предметного (межотраслевого) характера. Как показывает зарубежный и отечественный опыт, читатели больше предпочитают поиск по языкам вербального типа, чем по языкам классификационного типа. Каждый ИПЯ имеет свои достоинства и недостатки, поэтому проблему повышения эффективности поиска целесообразно решать путем использования достоинств каждого из языков индексирования.

Совместимость лингвистических средств (одна из важнейших проблем разработки лингвистического обеспечения) дает возможность использования в различных БД поисковых образов документов на одном ИПЯ, а поисковых предписаний на другом, т.е., на запросы, сформулированные на одном ИПЯ, должны быть даны ответы в различных БД. Обеспечить лингвистическую совместимость позволяют использование единых рубрикаторов, классификаторов, унифицированных коммуникативных форматов представления информа- 
ции в БД, тезаурусов и др. Существует несколько методов совместимости лингвистических средств:

- методологическая совместимость;

- стандартизация и унификация языковых средств;

- создание универсальных языковых средств;

- сосуществование различных ИПЯ в ЭК.

Именно совместимость средств лингвистического обеспечения различных БД существенно облегчит поиск и обмен необходимой информации.

Обмен данными. Учебные заведения все больше акцентируют внимание на увеличении доли самостоятельной работы в структуре учебного времени и более активно внедряют дистанционное образование. Разработка концепции и создания первых действующих региональных электронных библиотек, с учетом их последующего тесного взаимодействия между собой и с учебными заведениями, позволило бы в пределах общих проектов эффективнее использовать финансирование и быстрее достичь нужных результатов.

С 2007 года научно-техническая библиотека НТУ «ХПИ» начала заимствовать записи из ГПНТБ, благодаря участию в проекте «Автоматизированного банка данных Автоматизированной системы Российского сводного каталога научно-технической литературы», из ресурсов «МАРСа», благодаря присоединению к Российскому проекту Ассоциации региональных библиотечных консорциумов (АРБИКОН) и членству в российском проекте «Межрегиональная аналитическая роспись статей». С 2010 года — из ресурсов «Приднепровского корпоративного каталога». Анализируя результаты совместной работы, мы убедились, что реальная польза от сотрудничества очевидна:

1. Повысился интерес сотрудников к работе, возросла ответственность за имидж библиотеки, усилилась дисциплина выполнения заданий (сроки передачи записей, контроль кураторов проекта).

2. Значительно улучшилось качество создаваемых библиографических записей.

3. Полные аннотированные записи статей из 1625 русскоязычных наименований журналов доступны для ознакомления, а записи более чем 60\% периодических изданий, подписанных библиотекой, конвертируются из корпоративной базы.

4. Уменьшились трудозатраты на научную обработку документов. Выполняем аналитическую роспись всего 12 изданий.

5. Пользователи имеют возможность ознакомиться из содержанием журналов, которые не выписывает библиотека и оперативно получить полный текст любой статьи из БД «МАРС», воспользовавшись услугами службы проекта ЭДД, членом которого является наша библиотека с 2008 года.

6. Информационное обслуживание пользователей стало более эффективным и качественным.

7. Возрос престиж библиотеки.

Для обеспечения возможности обмена данными между ЭК разных организаций используется обменный или коммуникативный формат. Коммуникатив- 
ный формат позволяет согласовать структуру и характер записей в массивах и БД, являющихся объектами передачи и приема в процессах информационного взаимодействия систем. Требования коммуникативных форматов накладывают определенные ограничения по составу, структуре и правилам заполнения обязательных для каждого из них составов полей данных.

При вступлении в проект МАРС нам был предложен вариант рубрикатора, который используется в этой корпорации. Мы еще раз столкнулись с проблемой лингвистического обеспечения БД. Вначале в некоторых разделах рубрикатора не было развернутых предметных рубрик и подрубрик, было трудно выразить содержательную часть статьи. Профильные рубрики нашего вуза «Химическая технология», «Химия» и др. были мало информативны. Радует то, что к проекту все больше присоединялись вузовские библиотеки и репертуар журналов стал пополняться техническими и естественно-научными журналами. Это обстоятельство дало толчок для серьезной доработки рубрикатора. Сейчас уже сформирован двухуровневый рубрикатор рубрик и подрубрик, который постоянно дополняется новыми разделами, имеющий ссылки на индексы ББК, УДК, Классификации Дьюи. На его основе создаются машиночитаемые словари для всех версий используемого в библиотеках программного обеспечения.

При любом новом взаимодействии, всегда есть «за» и «против». Главное результаты наших усилий востребованы читателями. Совместно созданный продукт - библиографическая аннотированная база данных «МАРС» позволяет оперативно удовлетворять их информационные потребности и запросы. За три года корпоративного взаимодействия не только значительно улучшилось качество создаваемых библиографических записей, но и отладилась технология приема-передачи данных.

С ростом объемов накопленной информации возникает задание поиска по содержанию или по контексту и экспертного статистического анализа данных с целью предоставить пользователю возможность правильно сориентироваться в среде значительных массивов электронных фондов, а эксперту — возможность выделять подклассы текстов по избранной тематике.

Поскольку, основные группы читателей библиотек вузов преподаватели и студенты, то при определении стратегии лингвистического обеспечения БД следует помнить, что задание поиска информации возникает у пользователя, как правило, уже после первичного ознакомления с учебным материалом и имеет свои особенности. Поиск ведется по текстам из предметных областей с хорошо устоявшейся терминологией (учебные и методические пособия, программы курсов). Студентов, прежде всего, интересуют определения понятий, категорий (законы, теоремы), их свойства, соподчиненность и зависимость понятий (уравнения, методы и алгоритмы); они способны достаточно четко сформулировать свою осознанную информационную потребность в терминах предметной области.

С учетом всего вышеизложенного можно сформулировать требования к лингвистическому обеспечению информационно-поисковых систем: 
- метод поиска должен учитывать терминологический состав учебных материалов;

- запрос на поиск информации должен формулироваться языком, близким к языку профессиональной прозы предметной области;

- единицами поиска должны быть семантически законченные части учебного материала (разделы, подразделы учебных пособий);

- ключевыми словами должны быть категории научной лексики учебных дисциплин.

Активное внедрение в практику работы библиотек новых технологий предъявляет к лингвистическому обеспечению высокие требования. Поэтому оно находится в состоянии постоянного совершенствования. Обеспечение ЭК развитой системой лингвистического обеспечения является сложнейшей задачей для библиотек. Решение этой задачи существенно повышает эффективность использования ЭК.

\section{СПИСОК ИСТОЧНИКОВ}

1. Бочаров, Б. П. Роль бібліотек вищих навчальних закладів в організації дистаниійної освіти / Б.П. Бочаров, М. Ю. Воєводіна, Л. П. Семененко // Короленківські читання 2007 : матеріали наук. конф. ХДНБК, 8 жовтня 2007 р. - Х. : ХДНБК, 2007. - c. 12-17.

2. Воройский, Ф. С. Основные принципы обеспечения информационного поиска в корпоративных электронных каталогах / Ф. С. Воройский // Информационные технологии, компьютерные системы и издательская продукиия для библиотек : Восьмая Междунар. конф., 15-19 нояб. 2004 г. - Режим доступа : http://www.gpntb.ru/libcom

3. Воройский, Ф. С. Информационные ресурсы АРБИКОН - пора подумать об их качестве / Ф. С. Воройский, С. А. Острая // Науч. и техн. б-ки. - 2005. - № 2. - с. 76-83.

4. Зайцева, Е. М. Лингвистическое обеспечение автоматизированных библиотечно-информационных систем: современные требования $и$ направления развития / Е. М. Зайцева // Науч. и техн. б-ки. - 2000. № 3. - c. 54-57.

5. Моторина, А. Н. Лингвистическое обеспечение предметного поиска в электронном каталоге / // Библиотека вуза и информатизация общества: возможности и перспективы : зональная конф., 13-15 апреля 1998 г. / Южно-Урал. гос. ун-т. - Челябинск, 1998.

6. Пименов, Е. Н. Нормативность и некоторые проблемы разработки тезаурусов и других лингвистических средств ИПС / Е. Н. Пименов // НТИ. Сер. 1. Организация и методика информ. работы. - 2000. № 5. - c. 7-16.

7. Пирумова, Л. ИПЯ - язык, который надо знать: о роли лингвистического обеспечения в развитии информаџионно-поисковых систем биб- 
лиотек / Лидия Пирумова // Библиотека. - 2006. - № 10. - с. 61-65.

8. Полішук О. Редагування електронних каталогів - новий напрямок підвищення якості інформаиійного обслуговування користувачів бібліотек / О. Поліщук // Бібліотечний форум Украӥни. - 2006. - N 4. c. 27-30.

9. Скарук, Г. А. Тематический поиск в электронном каталоге: проблемы лингвистического обеспечения / Г. А. Скарук // Библиотековедение. 2001. - № 3. - c. 48-57.

10. Смагина, Н. Н. Лингвистическое обеспечение электронного каталога: консультация специалиста / Н. Н. Смагина // Вузовские б-ки Алтай. края : сборник. - Барнаул , 2003. - Вып. 3. - с. 40-42.

11.Шутько, Е. В. Аналитическая обработка текстовой информации и смысловой поиск в электронных базах данных: проблемы противоречий / Е. В. Шутько // Университетская библиотека: проблемы и решения : пятая Всерос. науч.-практ. конф. - Екатеринбург, 2003. c. $62-68$.

12.Шутько, Е В. О некоторых проблемах лингвистического обеспечения создания баз данных и поиска в электронном каталоге / Е. В. Шутько // Университетская библиотека на рубеже тысячелетий: выбор пути : третья ВсероС. науч.-практ. конф. - Екатеринбург, 2001. - Режим достуnа: http://consensus./conferences/unilib2000

13. Электронная учебно-методическая библиотека информационной системы «Единое окно доступа к образовательным ресурсам» : опыт формирования и перспективы развития / А. Г. Абрамов [и др.]. // Дистанционное и виртуальное обучение. - 2008. - № 4. - c. 4-15. 


\section{2. ЕЛЕКТРОННА БІБЛІОТЕКА В СИСТЕМІ ПІДГОТОВКИ МАЙБУТНЬОГО ВЧИТЕЛЯ ТРУДОВОГО НАВЧАННЯ}

Проблема створення єдиного освітнього простору вищого навчального закладу, орієнтованого на соціальне замовлення підготовки висококваліфікованого фахівця, повинна вирішуватися з урахуванням всіх вимог, що пред'являються до системи неперервної освіти, тобто обов'язково враховувати необхідність інформаційної підтримки процесу навчання засобами бібліотек.

На залучення вузівських бібліотек в освітній процес впливають ряд чинників: інформаційні, соціально-правові і технологічні. До інформаційних чинників відносяться: забезпеченість бібліотек інформаційними, методичними, педагогічними ресурсами, що сприяють підтримці неперервної освіти; до соціальноправових - нормативно-правова база бібліотек як публічних центрів правової соціально-значущої інформації; до технологічних чинників, насамперед, слід віднести рівень комунікаційних технологій бібліотек.

Інформаційно-освітнє середовище, на думку В. А. Ясвіна, є: «...системою впливів і умов формування особистості зазначеного зразку, а також можливостей для її розвитку, що містяться в соціальному і просторово-предметному оточенні, у тому числі і за допомогою бібліотечної дії. Створене в бібліотеці вузу інформаційно-освітнє середовище не $є$ чимось зовнішнім по відношенню до студента. Воно об'єднує студентів і формує їх» [2].

Для того щоб бібліотеки вузів змогли на сучасному рівні стати повноправними учасниками освітнього процесу, їм, на думку Н. В. Збаровської, необхідно вирішити декілька головних проблем:

1. Створити сучасну концепцію діяльності бібліотек з розвитку інформаційно-освітнього середовища на базі сучасних комунікаційних технологій, що сприяють інтеграції знань.

2. Організувати особистісно-орієнтований підхід в роботі зі студентом - тобто реалізувати провідний педагогічний принцип, який передбачає рівноправність учасників інформаційно-комунікативного процесу, що здійснюється в бібліотечному середовищі [1].

Важливими у розробці теоретичних основ розвитку бібліотек в електронному середовищі $\epsilon$ наукові напрацювання таких російських дослідників, як Т. А. Бахтуріна, Т. М. Кузмішина, І. Г. Моргенштерн, Ю. Н. Столярова та інших. Питання щодо сучасних тенденцій та перспектив розвитку електронних бібліотек аналізували зарубіжні науковці Г. А. Свстігнєєва, А. І. Земсков, Б. Е. Ленг, М. Г. Лінквіст, Роберт Д. Стюарт, Т. Манн, Я. Л. Шрайберг, вітчизняні дослідники Л. Й. Костенко, О. С. Онищенко, Т. П. Павлуша, І. А. Павлуша та інші.

Проблемі впровадження інформаційних і комунікаційних технологій, зокрема електронних бібліотек, у професійну діяльність вчителів присвячені роботи Б. С. Гершунського, О. В. Готовцевої, А. П. Сршова, М. І. Жалдака, Ю. І. Машбиця,В.М.Монахова, Н.В.Морзе, І. М. Пустинникової,Л.В.Савенкової, М. І. Шкіля та інших. 
Метою дослідження $є$ аналіз можливостей та розгляд можливих сфер застосування електронних бібліотек у професійній діяльності вчителя напряму «Технологічна освіта» та системі фахової підготовки майбутнього вчителя трудового навчання.

Забезпечення публічного (зокрема віддаленого) доступу студентів до електронних інформаційних ресурсів стало наразі одним 3 першочергових завдань інформаційного обслуговування системи підготовки майбутнього вчителя трудового навчання. Це пов'язано з тим, що в нинішніх умовах концепція інформаційного обслуговування, яка базується тільки на основі друкованих носіїв, застаріла, і їй на зміну прийшла інша, - заснована на електронному представленні найрізноманітнішої інформації, що тиражується в необмеженій кількості і миттєво доступна через глобальні мережі передачі даних незалежно від часу і місцезнаходження студента.

У зв'язку з цим істотно змінюються роль і функції бібліотеки - основного сховища і розповсюджувача інформації. Загальновизнано, що найбільш ефективне інформаційно-бібліотечне обслуговування інформаційних потреб майбутнього вчителя трудового навчання сьогодні (i тим паче завтра) досягається шляхом створення електронних бібліотек (digital libraries; далі - ЕБ) $є$ не тільки сховища електронних документів (як оцифрованих традиційних матеріалів, так і створених відразу в електронному вигляді), а і з колекцій, які є системою, що реалізовує уніфікований підхід до вироблення, зберігання і організації різноманітної інформації з метою пошуку, аналізу і доступу до неї з використанням комп'ютерних мереж.

Швидкий розвиток World Wide Web i мультимедіа-технології представляють основу для організації інформаційних колекцій і вказують напрями розвитку електронних бібліотек майбутнього. Разом з тим, електронні бібліотеки, що $€$ перспективними формами складних розподілених інформаційних систем, розглядаються як пілотні різновиди майбутніх розподілених сховищ знання (knowledge warehouses).

Основна відмінність традиційної і електронної бібліотек полягає в тому, що студент звертається до сервісів останньої за необхідною інформацією, а не просто за відсиланнями до документа i/або самого документа. Відмінною рисою ЕБ $\epsilon$ можливість паралельного використання різних пошукових механізмів і засобів доступу до гетерогенних колекцій електронних даних. Оскільки як відповідь на запит до ЕБ студентові може бути представлений не тільки один електронний документ (або його фрагмент) і зовсім не обов'язково в текстовій формі, у системі фахової підготовки майбутнього вчителя трудового навчання необхідні такі інформаційні системи, які можуть забезпечити ефективний комплексний пошук і аналіз інформації в колекціях різнорідних об'єктів.

Різноманітні форми представлення електронних колекцій включаються в інформаційні депозитарії, що $є$ компонентами системи підготовки майбутнього вчителя трудового навчання, проте до того часу, поки не вдасться досягти розумної однорідності в представленні таких форм, користувачі ЕБ матимуть значно більше незручностей в порівнянні з навчальною роботою 3 традиційними носіями інфор- 
мації. Отже, однією з фундаментальних проблем, що стоять перед дослідниками і розробниками ЕБ, є пошук шляхів раціонального відображення існуючої різноманітності електронних колекцій в їх однорідне представлення і забезпечення комфортного доступу до інтегрованої колекції неоднорідної інформації.

Застосування технологій ЕБ в системі підготовки майбутнього вчителя трудового навчання дозволяє вирішувати проблему зберігання великих обсягів наукової, культурної і навчальної інформації, здійснювати інтеграцію розрізнених інформаційних ресурсів, а також надає можливість зберігання різнорідної допоміжної навчальної інформації (лабораторних журналів, фотографій, зображень, звукової і відео інформації). Розроблені технології і програмно-апаратні рішення, що дають можливість оперувати різнорідними даними, знаходять застосування в самих різних варіаціях організації навчального процесу. В результаті розвивається інфраструктура для генерації, організації, пошуку і передачі різнорідної електронної інформації від інформаційних виробників до кінцевого студента (майбутнього вчителя трудового навчання), що суттєво змінює системні підходи до підготовки фахівця за напрямом «Технологічна освіта».

Електронні бібліотеки дають змогу докорінно змінити сам принцип інформаційного обслуговування майбутнього вчителя трудового навчання: звертаючись до системи, вони отримують не тільки посилання (бібліографію або реферат) на наявний електронний документ, але і сам документ (повну копію оригінальної статті, автореферат дисертації, графічний образ картини або технічного креслення, відеозапис проведеного дослідження або екскурсії по музею тощо).

Використання ЕБ дозволяє по-новому організувати робоче місце майбутнього вчителя трудового навчання шляхом реалізації можливості колективної дослідної роботи і навчання, створення колективних віртуальних середовищ. Окрім того, це знижує значущість наукових досліджень і дистанційної освіти за рахунок спільного використання ресурсів (наукових приладів, інформаційних систем тощо).

Місце ЕБ в системі підготовки майбутнього вчителя трудового навчання можна позначити двояко.

По-перше, ЕБ виступає компонентом освітнього простору. Реалізовуючи цю роль, вона організовує свою роботу на основі принципів структурнофункціонального підходу [3], використовуючи розгалужену структуру обслуговування (диференційоване задоволення запитів викладачів і студентів), тобто $\epsilon$ центром класифікації і систематизації предметно-галузевої і професійнопедагогічної інформації. Інформаційно-бібліографічна діяльність, при цьому, здійснюється відповідно до інформаційних запитів абонентів на основі їх широкого доступу до будь-яких фондів і баз даних.

По-друге, ЕБ можна представити як самостійне інформаційнокультурологічне середовище. 3 цих позицій ЕБ виступає одночасно каналом передачі інформації і каналом діяльності з відтворення елементів культури.

В умовах стрімкої інформатизації суспільної і особистої життєдіяльності майбутнього вчителя трудового навчання оптимальним може бути визначення 
електронного бібліотечного середовища як сукупності зовнішніх і внутрішніх умов, що сприяють ефективній взаємодії студента з інформацією. Отже, інформаційне бібліотечне середовище, засноване на сучасних технічних засобах доступу до інформаційно-навчальних ресурсів, є ядром в системі підготовки майбутнього вчителя трудового навчання [4].

Процес підготовки майбутнього вчителя трудового навчання слід розуміти як інформаційний процес формування знань і умінь у суб'єкта навчання під управлінням викладача. Як суб'єкт навчання розглядається індивідуум або група індивідуумів. Знання при цьому виступають як інформація, що здатна генерувати нову інформацію. Проведемо декомпозицію процесу навчання майбутнього вчителя трудового навчання на окремі етапи.

1. Володіння інформацією являє собою рівень знання, що полягає в здатності визначити призначення, місце інформації в змісті предмету і знайти потрібну інформацію, відповідаючи на питання типу: про що? з чим пов'язано? і де знайти?

2. Розуміння являє собою рівень знання, що полягає в здатності пояснити взаємозв'язки між поняттями предметної галузі, їх властивості, відповідаючи на питання типу: чому? звідки слідує?

3. Уміння вирішувати типові завдання являє собою рівень знання, що полягає в здатності побудувати обчислювальну схему рішення типової задачі, відповідаючи на питання - як вирішити?

4. Уміння вирішувати прикладні завдання являє собою рівень знання, що полягає в здатності декомпозитувати прикладне завдання на типові, сформувавши їх математичну постановку, й інтерпретувати результати їх розв'язання, виходячи з цілей початкового завдання.

5. Уміння синтезувати міжпредметні зв'язки являє собою рівень знання, що полягає в здатності використовувати для вирішення прикладних завдань предметної галузі знання різних предметів.

Досягнення перерахованих рівнів знання пов'язане із залученням тих або інших технологій навчання в систему підготовки майбутнього вчителя трудового навчання і виявляється у формуванні в свідомості студента згаданих вище смислових моделей і закріплення механізмів їх освоєння.

Самоосвіта майбутнього вчителя $\epsilon$ необхідною умовою його подальшої професійної діяльності. Суспільство завжди ставило і буде ставити до вчителя найвищі вимоги. Тому основною метою педагогічної освіти на сучасному етапі $\epsilon$ підготовка педагога відповідного рівня і профілю, конкурентоздатного на ринку праці, компетентної та відповідальної людини, що вільно володіє своєю професією і орієнтується в суміжних областях знань, здібної до ефективної роботи за фахом на рівні світових стандартів, готового до постійного професійного зростання, соціальної та професійної мобільності.

Самоосвіта як постійна діяльність вчителя включає:

- науково-дослідну роботу з визначеної проблеми;

- відвідування бібліотек, вивчення навчально-методичної та навчальної літератури; 
- участь у педагогічних радах, навчально-методичних об'єднаннях;

- відвідування уроків своїх колег, обмін думками з питань організації занять, змісту навчання, методів викладання;

- теоретичну розробку та практичну апробацію різних форм уроків, позакласних заходів та навчальних матеріалів.

Отже, ще одним важливим призначенням освітньої функції електронної бібліотеки є самоосвіта майбутнього вчителя трудового навчання у взаємодії з інформацією, що вимагає навичок взаємодії з інформацією, ознайомлення з каналами отримання інформації. У цьому сенсі ЕБ формує уміння працювати 3 носіями інформації і першоджерелами, допомагає визначити проблему і предмет самоосвіти, формує уміння складати бібліографічний список, аналізувати літературу (конспектувати, складати тези, писати анотації, рецензії, реферати) [5].

Наступним напрямом використання ЕБ в системі підготовки майбутнього вчителя трудового навчання є створення нетрадиційної інформаційної інфраструктури підтримки навчального процесу, тобто перетворення ЕБ на сучасний бібліографічно-інформаційний центр, що підтримує процес навчання і наукові дослідження, а також забезпечує системний доступ до знань і інформації.

Основними вимогами, що пред'являються до електронної бібліотеки в системі підготовки майбутнього вчителя трудового навчання, є:

- забезпечення ведення каталогу джерел (освітніх стандартів, навчальних програм, підручників, навчальних посібників, лабораторних практикумів, збірок вправ і завдань, навчальних і контролюючих програм, ілюстративних і презентаційних матеріалів, книг, журналів і так далі);

- організація системи пошуку та обліку читачів;

- організація зберігання і доступу до електронних видань;

- забезпечення процесу створення навчальних електронних підручників і системи методичної допомоги;

- забезпечення доступу до інформаційних ресурсів бібліотеки через локальну комп'ютерну мережу навчального закладу і мережу Інтернет.

Підручник $є$ засобом для засвоєння змісту освіти, і зазвичай містить навчальний матеріал, передбачений програмою по даному предмету. Разом з тим підручник - це не енциклопедичний довідник з відповідної галузі науки. Це своєрідний сценарій процесу навчання. Такий сценарій повинен відповідати визначеним педагогічним вимогам - відповідати цілям навчання та враховувати особливості процесу фахової підготовки майбутнього вчителя трудового навчання.

В наш час ідея широкого впровадження нових інформаційних технологій (HIT) в систему підготовки майбутнього вчителя трудового навчання, як педагогічної інновації, не викликає сумніву. Однак щодо конкретних проблем інформатизації навчально-педагогічної діяльності серед професорськовикладацького складу і фахівців ведеться чимало гострих наукових дискусій. I це цілком природньо. Процес пошуку і впровадження нових інноваційних технологій навчання тісно пов'язаний з розвитком нетрадиційних форм, методів $\mathrm{i}$ 
засобів навчання, заснованих на перевагах комп'ютерної техніки. Він відрізняється різноманітністю теоретичних поглядів і досвіду впровадження педагогічних інновацій. Ця ситуація стосується і концепції електронного підручника (ЕП).

Розробка і широке застосування ЕП допомагає технологічно забезпечити процес індивідуалізації навчання та вирішити деякі завдання дистанційного навчання. Крім того, електронний підручник дає змогу системно представити навчально-методичний матеріал, зробити його доступнішим для вивчення і відкритим для коректування і подальшого вдосконалення. Загалом ЕП - це електронна версія накопиченого викладачем навчально-методичного досвіду в процесі викладання конкретної навчальної дисципліни яка повинна широко представлятись в електронній бібліотеці, зокрема для підготовки майбутнього вчителя трудового навчання.

Методика використання електронної бібліотеки в системі підготовки майбутнього вчителя трудового навчання може бути представлена підготовчим етапом і етапом безпосереднього використання ЕБ в процесі навчання.

Підготовчий етап передбачає виконання ряду умов.

Організаційно-педагогічні умови.

1. Досягнення педагогами в професійній підготовці необхідного рівня готовності до застосування інформаційних технологій. Ця умова $є$ важливим чинником, що визначає здатність викладачів здійснювати проектно-комп'ютерне навчання.

У своєму становленні і розвитку готовність педагога до застосування засобів НІТ проходить три рівні.

На першому рівні педагоги застосовують інформаційні технології для вирішення вузкопредметных завдань навчального процесу як доповнення до традиційних засобів навчання для виконання навчальної, контролюючої, тренажерної i ігрової функцій. Прикладом першого рівня застосування інформаційнокомп'ютерних засобів може служити використання їх при вивченні предметів програми з метою проведення різних заліків, контрольних робіт і т.п.

Другий рівень передбачає використання педагогами інформаційних технологій для вирішення не тільки вузкопредметних, але і міжпредметних завдань навчального процесу, для посилення його інтегрованості, але як і раніше, в системі традиційних засобів навчання. Склад функцій інформаційних технологій на цьому рівні змінюється і включає: ігрову, моделюючу, дослідницьку функції, конструкторську і проектну діяльність.

На третьому рівні інформаційні технології служать педагогові для вирішення дидактичних завдань в інтегрованому навчальному процесі, для розвитку системного мислення студента. Тут комп'ютерні технології вже виходять на передній план, використовуються в системі нетрадиційних засобів навчання (комплекс комп'ютерних освітніх програм, комп'ютерні підручники і ін.).

2. Досягнення майбутніми вчителями трудового навчання необхідного рівня готовності до використання інформаційних технологій. Достатнім рівнем знань $\epsilon$ рівень, набутий в результаті вивчення дисципліни «Інформатика». 
3. Наявність кваліфікованого персоналу, що забезпечує адміністрування електронної бібліотеки.

4. Електронна бібліотека і іiї наповнення у вигляді посібників, методичної допомоги і т. п., мають бути фізично реалізовані.

Матеріально-технічні умови.

У системі підготовки майбутнього вчителя трудового навчання має бути створена відповідна матеріально-технічна база, що дозволяє ефективно експлуатувати електронну бібліотеку. Не вдаючись до деталей вимог до апаратнопрограмної платформи, вкажемо тільки, що в мінімальній конфігурації електронна бібліотека має бути встановлена на сервері $з$ операційною системою сімейства Windows, а комп'ютерний клас для проведення занять по мережі має бути пов'язаний з сервером бібліотеки. Доцільно також, щоб на сервері бібліотеки був встановлений Інтернет -сервер, що дозволяє здійснювати доступ до ресурсів бібліотеки через Інтернет з будь-якого віддаленого (зокрема домашнього) комп'ютера.

Етап безпосереднього використання електронної бібліотеки в системі підготовки майбутнього вчителя трудового навчання може виконуватися декількома способами.

1. Реальний навчальний процес йде по звичайних технологіях, а інформаційні технології застосовуються лише для проміжного контролю знань студентів у вигляді тестування. Цей підхід до організації освітнього процесу нам представляється дуже перспективним 3 огляду на те, що при його достатньо широкому використанні навчальний заклад може отримати серйозну економію ресурсів із-за нижчих витрат проведення мережевого комп'ютерного тестування в порівнянні з традиційним.

2. Представляє інтерес застосування освітніх інформаційних ресурсів як доповнення до традиційного навчального процесу. Ця форма має велике значення в тих випадках, коли на якісне засвоєння обсягу навчального матеріалу, передбаченого освітнім стандартом, не вистачає аудиторних занять згідно навчального плану. Крім того, використання такої форми організації навчального процесу можливо при неоднаковій початковій підготовці студентів. Розміщені на сервері електронної бібліотеки курси значною мірою сприяють якісному засвоєнню лекційного матеріалу і подальшій успішній здачі екзамену.

3. Представляють інтерес інтегровані технології організації навчального процесу, тобто різні поєднання занять в аудиторії і дистанційних занять.

В цьому випадку лектори і викладачі, що проводять практичні і семінарські заняття, до початку семестру складають і розміщують на сервері електронної бібліотеки графік навчального процесу, де детально описують порядок вивчення дисципліни в даному семестрі. Основний фактичний матеріал (електронний підручник), заздалегідь підготовлений лектором і забезпечений необхідною кількістю ілюстрацій і інтерактивних елементів, розміщується на сервері ЕБ разом 3 методичними рекомендаціями по його самостійному вивченню. Частина занять, якісне проведення яких із застосуванням мережевих інформаційних технологій поки не представляється можливим, плануються аудиторними. 
Слід особливо підкреслити, що при такому підході вкрай важливо забезпечити інтенсивний контроль ступеня засвоєння матеріалу. Як правило, з кожної теми передбачені велике за обсягом контрольне завдання або контрольне тестування, крім того, раз на 4-6 тижні (що визначається обсягом фактичного матеріалу) проводиться консультація викладача з теми, що вивчається. Хотілося б зазначити, що цей підхід до навчання студентів значною мірою нагадує західну модель організації навчального процесу, коли кількість аудиторних занять зведена до мінімуму і більшість часу студенти працюють самостійно.

Підсумовуючи вищесказане, відмітимо, що електронні бібліотеки і засоби міжмережевої взаємодії створюють принципово нові можливості використання цифрової інформації в системі підготовки майбутнього вчителя трудового навчання за рахунок створення і представлення нових інформаційних послуг, які забезпечують вільний віддалений доступ до великомасштабних інфраструктур та об'єднують розподілені інтерактивні цифрові архіви.

\section{СПИСОК ДЖЕРЕЛ}

1. Збаровская Н.В. Формирование информачионно-образовательной среды современных библиотек / Н. В. Збаровская // Библиотековедение. - 2006. - №4. - с. 50-54.

2. Ясвин В. А. Образовательная среда: от проектирования к моделированию / В. А. Ясвин. - М., 2001. - 368 с.

3. Солошенко Н. С. Централизованная библиотечная система как информационный посредник в научных исследованиях. (На примере Библиотеки по естественным наукам Российской Академии наук): Дис. канд. пед. наук: 05.25.03 - М.: МГУКиИ, 1999. - 171 с.

4. Марченко Е.К. Электронная библиотека как системообразуюший модуль системы дистанционного образования / Е. К. Марченко // Дистанционное образование. 1998. - №2.

5. Чернышов К. А. Информационное обеспечение образовательного проиесса высшей школы: Дис. канд. пед. наук : 13.00.01 - Таганрог, 2000$172 \mathrm{c}$. 


\section{КОРОТКІ ВІДОМОСТІ ПРО АВТОРІВ}

Бебик Валерій Михайлович - доктор політичних наук, кандидат психологічних наук, професор, проректор з політичних комунікацій Університету «Україна», голова робочої групи із суспільних комунікацій Громадської гуманітарної ради при Президентові України, досліджує проблеми масових комунікацій (м. Київ).

Бояріна Людмила Олександрівна - студентка факультету «Телекомунікації та вимірювальна техніка» Харківського національного університету радіоелектроніки, займається системами якості у бібліотеці (м. Харків).

Власова Тетяна Іванівна - доктор філософських наук, доцент, завідувач кафедри «Філологія та переклад» Дніпропетровського національного університету залізничного університету імені академіка В. Лазаряна (ДНУЗТ), спеціаліст 3 гендерних досліджень у філософії та літературі (м. Дніпропетровськ).

Влащенко Людмила Георгївна - заступник директора наукової бібліотеки Харківського національного університету радіоелектроніки, напрями наукової діяльності: електронні документи, системи якості у бібліотеці (м. Харків).

Волинець Валентина Миколаївна - заступник директора з наукової роботи науково-технічної бібліотеки Національного технічного університету України «КПІ», досліджує проблеми інтелектуальної обробки документів та діяльності бібліотек вищої школи із консолідації інформації (м. Київ).

Грищенко Тамара Борисівна - директор наукової бібліотеки Харківського національного університету радіоелектроніки, напрями наукової діяльності: електронні документи, системи якості у бібліотеці, інноваційні проекти (м. Харків).

Демченко Володимир Дмитрович - доктор філологічних наук, професор, декан факультету систем і засобів масової комунікації Дніпропетровського національного університету імені О. Гончара, досліджує проблеми сучасного розвитку масових комунікацій (м. Дніпропетровськ).

Дубчак Людмила Василівна - старший викладач кафедри інформаційних систем і технологій Національного університету державної податкової служби України, вивчає проблеми впровадження та використання інформаційнокомунікаційних технологій у бібліотечній справі (м. Ірпінь).

Кирко Світлана Юріївна - зав. сектору відділу наукової обробки документів та організації каталогів науково-технічної бібліотеки Національного технічного університету «Харківський політехнічний інститут», досліджує питання науко- 
вої обробки документів з використанням інфоромаційно-комунікаційних технологій (м. Харків).

Колесникова Тетяна Олександрівна - директор науково-технічної бібліотеки Дніпропетровського національного університету залізничного транспорту імені академіка В. Лазаряна, займається проблемами інформатизації бібліотек ВНЗ та розробленням комунікаційних моделей діяльності бібліотек ВНЗ (м. Дніпропетровськ).

Кондратюк Ірина Богданівна - вчений секретар наукової бібліотеки; Національний університет водного господарства та природокористування, займається питаннями історії бібліотек Волинської обасті та Західного регіону (м. Рівне).

Мямліна Антоніна Владиславівна - викладач кафедри реклами та зв'язків $з$ громадськістю Дніпропетровського національного університету ім. Олеся Гончара, займається проблемами теорії міфів в ЗМІ (м. Дніпропетровськ).

Назаровець Сергій Андрійович - бібліотекар II категорії наукової бібліотеки Національного університету «Львівська політехніка», сфера наукових інтересів: бібліометрія, вебліометрія, рух Open Access (м. Львів).

Непран Наталія Вікторівна - зав. інформаційно-бібліографічного відділу науково-технічної бібліотеки Національного технічного університету«Харківський політехнічний інститут» займаєтьтся питаннями впроважєення нових форм обслуговування користувачів в умовах зміни парадигми освіти та видавничої справи (м. Харків).

Нікітенко Олександр Миколайович - кандидат технічних наук, доцент кафедри «Метрологія та вимірювальна техніка», старший науковий співробітник Харківського національного університету радіоелектроніки, напрями наукової діяльності: прилади НВЧ, динамічний хаос, автоматизовані бібліотечні системи, системи якості у бібліотеці (м. Харків).

Пекур Олена Володимирівна - зав. відділом інформаційно-комунікаційних технологій наукової бібліотека Національного педагогічного університету імені М.П. Драгоманова, досліджує педагогічні умови використання інформацйнокомунікаційних технологій бібліотеки ВНЗ у підготовці майбутнього (м. Київ).

Перепелиия Ірина Григорівна - директор державного підприємства «Центральна державна науково-технічна бібліотека гірничо-металургійного комплексу України», працює над розробкою теорії і практики формування електронних ресурсів гірничо-металургійної галузі, організації до них доступу (м. Дніпропетровськ). 
Романова Валентина Михайлівна - директор науково-технічної бібліотеки Самарского державного університету шляхів сполучення, вивчає питання системного реформування бібліотек університетів в умовах трансформації вищої освіти (м. Самара, Росія).

Савенкова Людмила Василівна - кандидат педагогічних наук, директор наукової бібліотеки Національного педагогічного університету імені М. П. Драгоманова, досліджує підвищення якості обслуговування користувачів та формування документно-ресурсної бази бібліотеки вищого навчального закладу (м. Київ).

Семененко Лариса Петрівна - директор науково-технічної бібліотеки Національного технічного університету «Харківський політехнічний інститут», займається проблемами трансформації складових бібліотечної діяльності в умовах розвитку інформаційно-комунікаційних технологій (м. Харків).

Ткаченко Тетяна Петрівна - директор наукової бібліотеки Донецького національного університету економіки i торгівлі імені Михайла ТуганБарановського, займається питанням менеджменту якості університетської бібліотеки в умовах перебудови вищої освіти (м. Донецьк).

Цимбалюк Світлана Ярославівна - кандидат економічних наук, директор наукової бібліотеки Національного університету державної податкової служби України, вивчає інформаційно-бібліотечне забезпечення економіки природокористування та охорони навколишнього середовища (м. Ірпінь).

Ящанов Сергій Микитович - кандидат педагогічних наук, професор, завідувач кафедри інформаційних систем Інституту гуманітарно-технічної освіти, директор центру комп'ютеризації та інформаційного забезпечення Національного педагогічного університету імені М. П. Драгоманова, досліджує питання формування та інтеграції навчальних інформаційних ресурсів педагогічної сфери (м. Київ). 


\section{MICT}

ПЕРЕДМОВА...........................................................

Розділ I

БІБЛІОТЕКА В СИСТЕМІ СОЦІАЛЬНИХ КОМУНІКАЦІЙ

1.1. Соціальні комунікації та їх роль у функціонуванні суспільної

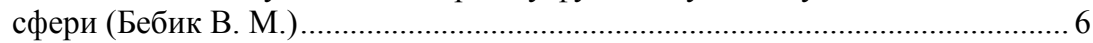

1.2. Соціальні комунікації в умовах інформаційного суспільства:

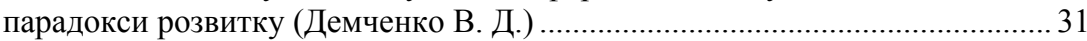

1.3. Литература и культурно-смысловые проблемы теории

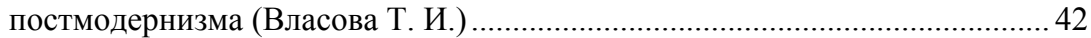

1.4. Університетська бібліотека на сучасному етапі розвитку

соціальних комунікацій (Колесникова Т. О.)

1.5. Наукова бібліотека НУВГП в інформаційному суспільстві:

інновації, стратегії, технології (Кондратюк І. Б.)........................................... 60

Розділ II

БІБЛІОТЕКА І ОСВІТА УМОВАХ ІНФОРМАТИЗАЦІЇ

2.1. Вплив інформатизації на стан розвитку

бібліотек ВНЗ (Колесникова Т. О.).

2.2. Педагогічні умови використання мультимедійних інструкцій до

web-каталогу у підготовці майбутніх учителів (Пекур О. В.) ........................ 85

2.3. Медіаосвіта як розуміння світу медіа (Мямліна А. В.) ……………........ 92

Розділ III

ФОРМУВАННЯ І ВИКОРИСТАННЯ БІБЛІОТЕЧНО-ІНФОРМАЦІЙНИХ PECУРСIB

3.1. Кластер як нова регіональна модель інтеграції бібліотек ВНЗ:

концептуальні характеристики та умови реалізації (Колесникова Т. О.) ....98

3.2. Информационные ресурсы отраслевых научно-технических

библиотек открыты студентам (Перепелиця І. Г.)

3.3. Современные задачи вузовской библиотеки в контексте

корпоративной деятельности (Романова В. М.) …….................................. 118

3.4. Системний підхід до створення електронної бібліотеки в

інформаційному середовищі ВНЗ (Цимбалюк С. Я., Дубчак Л. В.)

Розділ IV

ІНТЕЛЕКТУАЛЬНІ ТЕХНОЛОГІЇ В БІБЛІОТЕЧНО-ІНФОРМАЦІЙНІЙ СФЕРI

4. 1. Бібліометричні дослідження як аналітичний інструмент

оптимізації наукової роботи ВНЗ (Савенкова Л. В., Волинець В. М.) ....... 136

4.2. Інституційні репозитарії як поштовх до нових бібліометричних

досліджень в Україні (Назаровець С. А.)

Розділ V

АКТУАЛЬНІ ПИТАННЯ БІБЛІОТЕЧНОГО МЕНЕДЖМЕНТУ

5.1. Система менеджменту якості наукової бібліотеки ВНЗ в умовах перебудови системи вищої освіти (Ткаченко Т. П.) 
5.2. Система менеджменту якості в бібліотеці технічного університету

(Бояріна Л. О., Влащенко Л. Г., Грищенко Т. Б., Нікітенко О. М.).............. 166 Розділ VI

ЗАБЕЗПЕЧЕННЯ РОБОТИ ФУНКЦІОНАЛЬНИХ ПІДСИСТЕМ БІБЛІОТЕКИ

6.1. Лингвистическое обеспечение электронного каталога: опыт и проблемы (Семененко Л. П., Непран Н. В., Кірко С. Ю.) 178

6.2. Електронна бібліотека в системі підготовки майбутнього вчителя трудового навчання (Яшанов С. М.) 185 КОРОТКІ ВІДОМОСТІ ПРО АВТОРІВ 


\section{ДЛЯ НОТАТОК}




\section{ДЛЯ НОТАТОК}


Наукове видання

За загальною редакиією д-ра історичних наук

В. О. Ільганаєвої та Т. О. Колесникової

\title{
БІБЛІОТЕКА ВНЗ НА НОВОМУ ЕТАПІ РОЗВИТКУ СОЦІАЛЬНИХ КОМУНІКАЦЙ
}

\author{
Монографія \\ (украӥнською та російською мовами)
}

Редактори В. О. Ільганаєва, Т. О. Колесникова Відповідальний за випуск T. О. Колесникова

Технічниий редактор $H$. C. Хорошилова

Комп'ютерна верстка $A$. A. Заіченко

Дизайн обкладинки C. В. Герасімова

Видавництво Маковецький Юрій Вадимович Свидоцтво ДК № 2665 від 25.10.2006 р.

49000, Україна, м. Дніпропетровськ, вул. Плеханова, 16, к.14

Тел. (056) 798-33-64, факс (0562) 36-79-93

e-mail: europress@gala.net

Надруковано:

ТОВ фірма „Вета”. м. Дніпропетровськ, вул. Наб. Леніна, 9, тел. (056) 370-30-22.

Підписано до друку 25.09.10. Формат 29,7x42 1/4.Папір офсетний.

Спосіб друку - різограф. Умов.друк.арк. 11,55. Тираж 300 прим. 


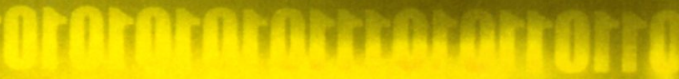

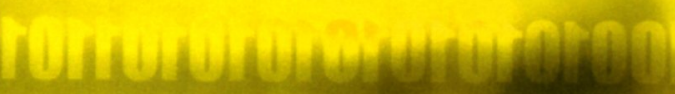

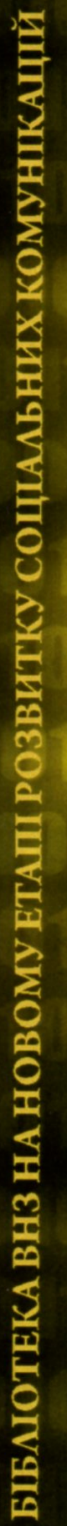
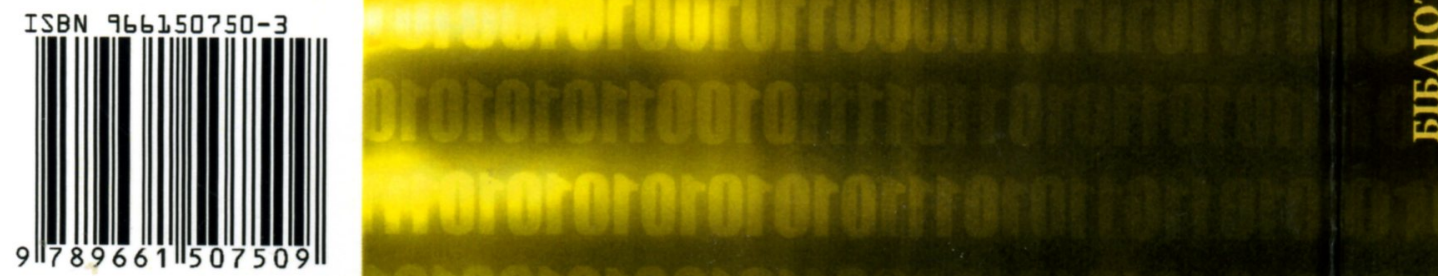